Ks. Józef Wołczański

Kraków

\title{
Listy abp. Józefa Teodorowicza do abp. Józefa Bilczewskiego z lat 1900-1923
}

\section{Wprowadzenie}

Kościół katolicki w Galicji na początku XX stulecia funkcjonując w ramach monarchii austro-węgierskiej i podlegając różnego rodzaju ograniczeniom wynikającym z tego faktu, posiadał - obok wielu innych - szczególnie jeden cenny atut: wybitnych biskupów. Uwaga ta odnosi się do pasterzy trzech obrządków na terenie Galicji: rzymskokatolickiego, ormiańskokatolickiego i greckokatolickiego. Spośród nich, szczególnie dwaj wyróżniali się nie tyle z racji piastowanego urzędu, a co za tym idzie prestiżu w hierarchii społecznej, ile raczej walorami dojrzałej osobowości oraz skalą zaangażowania w problematykę religijno-narodową. Byli to: abp Józef Bilczewski - metropolita lwowski obrządku łacińskiego i abp Józef Teodorowicz - zwierzchnik Kościoła ormiańskiego z siedzibą we Lwowie. To właśnie listy ostatniego z wyżej wymienionych, najpierw jako kanonika Kapituły Katedralnej, a później arcybiskupa kierowane pod adresem metropolity rzymskokatolickiego stanowią przedmiot niniejszej edycji. Zanim wszakże przemówią dokumenty, warto przyjrzeć się bliżej sylwetce adresata listów ormiańskiego hierarchy - metropolity lwowskiego ob. łac. Józefa Bilczewskiego.

Przyszły rządca łacińskiej metropolii lwowskiej zarówno pochodzeniem, studiami oraz inkardynacją kościelną związany był z Ziemią i Kościołem krakowskim. Przyszedł na świat 26 IV 1860 r. w Wilamowicach k. Kęt jako syn wielodzietnej rodziny chłopskiej Franciszka Biby i Anny Fajkisz. Od wczesnego dzieciństwa nie przejawiał ani zainteresowania, ani też nie miał wrodzonych predyspozycji do podjęcia rodzinnych tradycji związanych ze stanem społecznym przodków. Pochłonięty pasją zdobywania wiedzy, po ukończeniu szkoły powszechnej w rodzinnej miejscowości i Kętach, kontynuował naukę na szczeblu gimnazjalnym w Wadowicach (1872-1880), składając egzamin maturalny z wyróżnieniem. Po maturze wstąpił do Seminarium Duchownego w Krakowie, rozpoczynając zarazem studia filozoficzno-teologiczne na Uniwersytecie Jagiellońskim (1880-1884). Okres formacji ascetyczno-intelektualnej uwieńczył przyjęciem święceń kapłańskich 6 VII 1884 r. w Krakowie. Najbliższy rok spędził na etacie wikariusza w Mogile, dokonując także wówczas zmiany nazwiska na „Bilczewski”. Kolejny rok 1885-1886 poświęcił na studia teologiczne w murach Uniwersytetu Wiedeńskiego, uzyskując tam 18 X 1886 r. doktorat teologii. Przez następne dwa lata studiował na Uniwersytecie Gregoriańskim w Rzymie. Z chwilą powrotu do kraju, ponownie objął stanowisko wikariusza, 
najpierw w Kętach (1888-1889), a później w parafii pw. Wszystkich Świętych w Krakowie (1889-1890) i katechety w Gimnazjum św. Anny (1890-1891) tamże. Po uzyskaniu habilitacji na Wydziale Teologicznym UJ 18 VI 1890 r . został mianowany 14 I 1891 r. profesorem nadzwyczajnym teologii dogmatycznej na Uniwersytecie Lwowskim. Dwa lata później, 28 I 1893 r. otrzymał nominację ma profesora zwyczajnego. W środowisku uniwersyteckim pełnił w roku akad. 1896/97 obowiązki dziekana Wydziału Teologicznego, w roku akad. 1897/98 prodziekana, zaś u progu roku akad. 1900/01 wybrano go rektorem uczelni. Z funkcji tej niebawem zrezygnował, bowiem 30 X 1900 r. cesarz Franciszek Józef mianował go arcybiskupem lwowskim obrządku łacińskiego; w ślad za tym nadeszła prekonizacja papieska 17 grudnia t.r., po czym 20 I 1901 r. nominał przyjął sakrę biskupią i odbył ingres do Katedry Metropolitalnej we Lwowie ${ }^{1}$.

Wbrew opiniom sceptyków podważających kwalifikacje pastoralno-praktyczne stosunkowo młodego wiekiem profesora uniwersyteckiego do kierowania rozległą, zróżnicowaną etnicznie, społeczno-gospodarczo i kulturalnie archidiecezją lwowską, abp Bilczewski okazał się nie tylko sprawnym administratorem, wytrawnym mężem stanu, ale nade wszystko wrażliwym na „znaki czasu” pasterzem. Z niezwykłą wprost determinacją patronował akcji rozbudowy sieci parafialnej oraz wznoszenia kościołów; na przestrzeni 23-letniego pontyfikatu metropolity erygowano 21 parafii i 96 filii parafialnych oraz wybudowano 328 świątyń i kaplic. Reagując na idee zawarte w encyklice Leona XIII Rerum novarum zainicjował szeroko rozwiniętą akcję chrześcijańsko-społeczną w archidiecezji lwowskiej metodą zakładania stowarzyszeń, organizacji oraz czasopism katolickich. W nauczaniu chętnie korzystał zarówno z osobistych kontaktów z wiernymi, m.in. podczas wizytacji kanonicznych parafii, jak również dzięki listom pasterskim, odezwom i okólnikom. Zawarł w nich wszechstronną problematykę teologiczno-pastoralną, jak również społeczno-patriotyczną. Dzięki swej postawie głęboko zaangażowanej w najważniejsze sfery życia kościelno narodowego, cieszył się niekłamanym autorytetem zarówno w Polsce, jak i poza jej granicami. Papież Pius X uważał go za jednego z najwybitniejszych biskupów w ówczesnym Kościele Powszechnym. Zmarł 20 III 1923 r. we Lwowie w opinii świętości; pochowano go wśród najuboższych mieszkańców miasta na Cmentarzu Janowskim. Dnia 26 VI 2001 r. został beatyfikowany przez Jana Pawła II we Lwowie, a 23 X 2005 r. Benedykt XVI dokonał aktu jego kanonizacji w Rzymie².

${ }^{1}$ F. Stopniak, Bilczewski Józef w: SBKSwP, t. 1, red. zbior., Warszawa 1991, s. 30-32; M. Tarnawski, Arcybiskup Józef Bilczewski. Krótki rys życia i prac, Lwów 1924, passim; Btogostawiony Józef Bilczewski arcybiskup metropolita lwowski obrzadku łacińskiego. Sesja naukowa na Uniwersytecie Jagiellońskim, Kraków 4-5 czerwca 2002, red. J. Wołczański, Kraków 2003, passim; J.C. Kałużny, Święty Józef Bilczewski badacz starożytności chrześcijańskiej i jego interdyscyplinarna metoda w świetle nieznanych materiałów źródtowych $z$ lat 1885-1900, Lwów-Kraków 2015, passim; „Nic dla siebie, wszystko dla Boga i bliźniego”. Święty arcybiskup Józef Bilczewski we wspomnieniach, oprac. J. Wołczański, Lwów-Kraków 2016, passim; AALK, bsygn., Josephi Bilczewski archiepiscopi Leopolitani latinorum 1860-1923 positio super vita et virtutibus, Roma 1996, passim, mps.

${ }^{2}$ M. Dębowska, Akcja społeczna $w$ archidiecezji lwowskiej za rzadów arcybiskupa Józefa Bilczewskiego (1901-1923), ABMK, t. 61, Lublin 1992, s. 227-374; M. Tarnawski, Arcybiskup, passim; „Nic dla siebie, wszystko dla Boga i bliźniego", passim; Visitatio pastoralis Summi Pontificis Ioannis Pauli PP. II in Ucraina diebus 23-27 iunii A.D. 2001, [Romae 2001], s. 177-210; informacje własne autora. 
Osobiste, bliskie więzy łączące obu hierarchów datowały się zapewne od 1897 r., kiedy to ks. Józef Teodorowicz osiadł na stałe we Lwowie. Wprawdzie w tym samym mieście już od sześciu lat działał ks. Józef Bilczewski, ale zarówno środowiska w jakich obaj się poruszali, jak też odmienne funkcje przez nich pełnione nie sprzyjały raczej nawiązaniu wcześniejszych obustronnych kontaktów. Doskonałą płaszczyznę porozumienia pomiędzy nimi stwarzała nie tylko sfera towarzyska, ale nade wszystko kościelno-religijna. Jednym z jej istotnych komponentów była rodząca się wówczas w Galicji akcja chrześcijańsko-społeczna, w której obaj duchowni próbowali swoich sił na miarę nie tyle merytorycznego przygotowania, ile raczej wewnętrznej pasji oraz idealizmu. Na przełomie XIX i XX stulecia katolickie środowisko Lwowa poszukiwało skutecznego medium formowania opinii publicznej w duchu idei encykliki Leona XIII Rerum novarum, jak również przygotowania dojrzałych elit do praktycznego wprowadzania ich w życie. Przy współpracy m.in. ks. Teodorowicza powstał wówczas w 1897 r. we Lwowie dziennik „Ruch Katolicki”. Można bez obawy błędu przypuszczać, że do grona współpracowników pozyskano z całą pewnością ówczesnego profesora dogmatyki Uniwersytetu Lwowskiego ks. Bilczewskiego, cieszącego się nie tylko sławą znakomitego wykładowcy, ale też utalentowanego pisarza. Chociaż nie można jednoznacznie stwierdzić jego autorstwa publikowanych na łamach wspomnianego wyżej pisma artykułów, gdyż większość z nich nie sygnowano, to jednak wydaje się nader prawdopodobne zaangażowanie tak płodnego uczonego w nowe dzieło jednoczące katolików bez względu na obrządek religijny i narodowość. Tezę tę zresztą potwierdza wyraźny wątek obecny w listach ks. Teodorowicza do ks. Bilczewskiego.

W zachowanej korespondencji ormiańskiego duchownego adresowanej do rektora Uniwersytetu Lwowskiego, a wkrótce metropolity lwowskiego obrządku łacińskiego, wyraźnie zarysowuje się kilka kręgów tematycznych. Niezwykle wyraziście wyodrębnia się obszar problemów związanych z edycją dzienników: „Ruchu Katolickiego” i „Przedświtu”, w której czynnie uczestniczyli obaj duchowni. Ani abp Bilczewski, ani abp Teodorowicz nie posiadali merytorycznego przygotowania do prowadzenia skomplikowanych skądinąd agend prasowych. O ile metropolita łaciński ograniczał się $\mathrm{w}$ zasadzie do ingerencji w sferę programową, jak również finansową, zwłaszcza „Przedświtu”, o tyle ormiański hierarcha usiłował panować nad całokształtem problematyki edytorskiej. Powoływał się na fakt, iż pismo „[... jest dzieckiem jego duchowym i którego obraz duchowy i kierunek on wykołysał w duszy"3. Dość wcześnie jednak pojawiły się kłopoty związane z obsadą personalną redakcji, zakresem kompetencji jej członków oraz nieodłącznymi kwestiami materialnymi. Ostatecznie wskutek braku porozumienia pomiędzy głównymi liderami „Przedświtu”, a co za tym idzie narastającymi kłopotami finansowymi, sprawa znalazła swój epilog w nuncjaturze wiedeńskiej. Taki obrót sprawy wpłynął rzecz jasna na ochłodzenie relacji na linii abp Bilczewski - abp Teodorowicz, przejawiając się m.in. w formie wzajemnych oskarżeń,

${ }^{3}$ List $\mathrm{nr} 16$ niniejszej edycji. 
pretensji, pełnych goryczy wyrzutów. Pismo uległo całkowitej likwidacji w 1903 r., a dotychczasowe nieporozumienia ustąpiły miejsca pozytywnej współpracy, przeradzającej się z upływem czasu w przyjaźń. Wydaje się, że informacje dotyczące kulisów narodzin, rozwoju i wreszcie upadku „Przedświtu” pochodzące spod pióra animatora pisma wnoszą istotny wkład w badania nad polską prasą katolicką przełomu XIX/XX wieku.

Innym ważnym elementem występującym w korespondencji jest tzw. sprawa bp. Władysława Bandurskiego. Jako biskup pomocniczy archidiecezji lwowskiej ob. łac. współpracował z abp. Bilczewskim, ale dość wcześnie pojawiły się między nimi rozdźwięki. Ich źródło tkwiło przede wszystkim w odmiennym pojmowaniu kwestii narodowej. O ile obaj byli bez wątpienia żarliwymi polskimi patriotami, o tyle różnili się metodą artykułowania swych przekonań. Abp Bilczewski z racji pełnionej funkcji zwierzchnika Kościoła rzymskokatolickiego w Galicji musiał siła rzeczy prezentować postawę lojalizmu względem monarchii austro-węgierskiej, co nie oznaczało bynajmniej bezdusznego serwilizmu. Tymczasem bp Bandurski wykorzystywał każdą nadarzającą się okazję, aby demonstrować pełne poparcie dla rodzącej się idei walki o odrodzenie Polski. Dosadnie jego postawę skomentował namiestnik Michał Bobrzyński: „Ja umieram wprost na tego człowieka; przy każdej sposobności, przy każdym poświęceniu choćby ślizgawki mówi zaraz o niepodległej Polsce"

Oprócz zarzutów o zbyteczne zaangażowanie się hierarchy w sprawy polityki doszły jeszcze dość enigmatyczne, a przy tym oparte o wątpliwej natury poszlaki oskarżenia natury moralnej, formułowane głównie przez metropolitę Bilczewskiego, a przyjęte

${ }^{4}$ Niezwykle surową ocenę zarówno linii programowej „Przedświtu”, jak i zespołowi redakcyjnemu wystawił Czesław Lechicki: „Już sam nagłówek «Przedświt», ledwo nieodpowiedni dla dziennika, dowodzący rozkochania w Krasińskim i najpopularniejszym jego utworze. Układ zewnętrzny natomiast nowatorski, bo francuski, z jak najbardziej rozbitą kolumną, na której oko nie ma się gdzie zatrzymać, która rozprasza orientację czytelnika, do której trzeba go dopiero przyzwyczajać. Pierwsze wrażenie niekorzystne: sieczka dziennikarska, z którą oswoiły później brukowce typu ekspresowego. Brak lub zły dobór tytułów pogłębiał to wrażenie. Pomieszanie działu publicystycznego z informacyjnym, przeplatanie jednego drugim, przy mało pomysłowym, przypadkowym lub niedbałym łamaniu maksymalnej, sześcioszpaltowej kolumny daje już wizualnie efekt chaotyczności. Brak stałego artykułu wstępnego treści aktualno-politycznej. Nieprzejrzysta klasyfikacja materiału redakcyjnego, widoczna przewaga informacji nad publicystyką - to dalsze cechy zewnętrzne tego dziennika. Jego defekty równoważyłby doskonały serwis informacyjny [...]. Brak fachowego, jednolitego kierownictwa redakcją zemścił się wkrótce; pismo było prowadzone po dyletancku, niby bezpartyjne, a w prasie galicyjskiej izolowane, nawet nietraktowane zbyt serio, gorzej w każdym razie od „Ruchu Katolickiego”. Nie pomagała obniżka ceny prenumeraty, a nawet kupno drukarni. Sympatie polityczne kierowały się raczej w stronę klarującego się ruchu wszechpolskiego niż wobec konserwatystów. [...]. Zostawszy arcybiskupem ks. Teodorowicz przestał się zajmować redakcją, troszczył się jednak o środki finansowe dla podupadającego dziennika, episkopat galicyjski nie kwapił się bowiem do subwencji. [...]. Znaczną część odpowiedzialności za smutne losy «Przedświtu» ponosił jego protektor arcyb[iskup] Teodorowicz, który na dziennikarstwie się nie znał, a chciał je reformować”. C. Lechicki, $Z$ dziejów prasy galicyjskiej na przetomie dwóch wieków. („Ruch Katolicki” - „Przedświt”), SH, 14(1971), z. 2, s. 177, 181-182; tenże, Polskie czasopiśmiennictwo katolickie w latach 1833-1914, KHPP, 23(1984), s. 35-36.

${ }^{5}$ J. Wołczański, Adam Stefan Sapieha w korespondencji z biskupami Galicji (Małopolski) w latach 1900-1939, w: Kardynat Adam Stefan Sapieha. Środowisko rodzinne, życie i dzieło, red. S. Stępień, Przemyśl 1995, s. 109. 
i powtarzane przez pozostałych biskupów polskich. W rezultacie rozpętanej kampanii, bp Bandurski został zmuszony w 1917 r. do rezygnacji z sufraganii lwowskiej i opuszczenia Lwowa. Zanim do tego doszło, biskupi - w tym abp Teodorowicz - prowadzili stałą inwigilację inkryminowanego dostojnika Kościoła, skrzętnie gromadząc informacje wymierzone w jego osobę. Tego rodzaju taktyka znalazła swoje odbicie także w listach ormiańskiego arcybiskupa do metropolity łacińskiego Lwowa. Na korzyść wszakże pierwszego z nich przemawia fakt niekonsekwencji w procesie dyskredytowania bp. Bandurskiego, co można chyba odczytać nie tyle jako próbę pomieszania szyków abp. Bilczewskiemu, ile raczej braku pełnego przekonania o winie sufragana.

Kolejnym problemem wyłaniającym się z listów abp. Teodorowicza jest kwestia reformy wyborczej w Galicji. W 1913 r. namiestnik Michał Bobrzyński opracował kompromisowy projekt ordynacji wyborczej do Sejmu. Zakładał on wprowadzenie obok dotychczasowych czterech kurii dodatkowej piątej tzw. „średniej własności”. Ponadto przewidywał dwie kurie powszechne: wiejską i miejską oraz zwiększał liczbę posłów wirylnych. Dla Ukraińców zagwarantowano 27\% mandatów, a dla Polaków w Galicji Wschodniej zarezerwowano kilkanaście mandatów „mniejszościowych”. W tej sytuacji zarówno endecja, jak i Kościół rzymskokatolicki uznali projekt ordynacji wyborczej za szkodliwy dla interesów Kościoła i polskiej społeczności w Galicji ${ }^{6}$. W pierwszych tygodniach marca $1913 \mathrm{r}$. namiestnik Bobrzyński skierował do biskupów zaproszenie do udziału w głosowaniu na forum Sejmu Galicyjskiego, bowiem liczyć miał się każdy głos. Tymczasem biskupi rozpoczęli debaty nad owym projektem, całkowicie go dyskredytując. Jednocześnie postanowili uchylić się od głosowania, podejmując decyzję wyjazdu na ten czas do Rzymu. Wprawdzie tylko dwóch spełniło tę zapowiedź, ale żaden z grona episkopatu łacińskiego i ormiańskokatolickiego nie przybył na salę sejmową. W tej sytuacji Bobrzyński podał się do dymisjī. Różnorodne aspekty tej sprawy mieszczą się na kartach listów abp. Teodorowicza.

Ponadto znalazły w nich swe odbicie również problemy życia społeczno-narodowego i kościelnego II Rzeczypospolitej. Spośród ważniejszych kwestii należy wymienić zaangażowanie hierarchy na rzecz zakończenia konfliktu zbrojnego ukraińsko-polskiego w Małopolsce Wschodniej 1918-1919 r., udział tegoż w rozstrzygnięciu sporów wokół plebiscytu śląskiego, obecność w polskim parlamencie, prace w komisjach kościelno-państwowych.

Lektura listów dostarcza także interesujących danych odnośnie do prześledzenia skali personalnych więzi łączących obu dostojników kościelnych. Początkowo tytulatura nosi znamiona oficjalnej hieratyczności, a narastające napięcia wywołane nieporozumieniami w związku z redagowaniem „Przedświtu " znajdowały swoje odbicie w postaci rozległej skali emocji. Wraz z rozstrzygnięciem spornych kwestii, pojawił się od $1910 \mathrm{r}$. ton kolokwialnej poufałości, właściwy nie tylko równorzędnym partnerom w hierarchii społeczno-kościelnej, ale przede wszystkim łączący wypróbowanych przyjaciół.

\footnotetext{
${ }^{6}$ S. Kieniewicz, Historia Polski 1795-1918, Warszawa 1983, s. 472.

7 Szerzej na ten temat zob.: AALK, bsygn., J. Bilczewski, Dziennik 1900-1921, Lwów 1900-1921, s. 251283, mps.
} 
Pomimo zdarzających się w kolejnych latach drobnych incydentów, przyjaźń obu dostojników skutecznie oparła się próbie czasu.

Niniejsza edycja prezentuje 155 listów abp. Teodorowicza skierowanych do metropolity Bilczewskiego w latach 1900-1923, a więc za cały czas pontyfikatu tegoż ostatniego. $\mathrm{Z}$ całą pewnością nie jest to kompletna kolekcja, chociaż zawiera wszystkie dokumenty zachowane do chwili obecnej. Inne prawdopodobnie nie dotrwały z różnych względów do naszych czasów. Publikowane tu materiały przechowywane są w Archiwum Archidiecezji Lwowskiej obrządku łacińskiego w Krakowie. Stanowią one fragment spuścizny archiwalnej abp. Józefa Bilczewskiego. Wszystkie listy są oryginałami, rozproszonymi w teczkach bez sygnatur mieszczących korespondencję różnych osób do lwowskiego metropolity. Pomimo poszukiwań, nie udało się dotrzeć do listów autorstwa abp. Bilczewskiego adresowanych do ormiańskiego hierarchy, nie wiadomo nawet, czy dotrwały do chwili obecnej. Korespondencja niżej prezentowana została ogłoszona już wcześniej drukiem przez piszącego te słowa na łamach "Przeglądu Wschodniego", a obecnie $\mathrm{w}$ poprawionej i uzupełnionej wersji znalazła się w niniejszym tomie studiów. Wnosi ona bowiem bezcenny wkład w bliższe poznanie osobowości jej autora, jego relacji z ówczesnym metropolitą lwowskim obrządku łacińskiego oraz prezentuje zaangażowanie obu hierarchów w nurt życia kościelnego, narodowego i społeczno-politycznego Galicji (Małopolski Wschodniej) I poł. XX stulecia.

W edycji zastosowano aparat naukowy właściwy publikacjom źródeł historycznych. Literami alfabetu łacińskiego oznaczono wyjaśnienia natury formalnej, natomiast cyframi arabskimi - informacje merytoryczne. Ponadto oparto się na współczesnych zasadach polskiej pisowni, rezygnując z licznych archaizmów.

${ }^{8}$ J. Wołczański, Listy arcybiskupa Józefa Teodorowicza do arcybiskupa Józefa Bilczewskiego z lat 19001923, PW, 2003, t. 8, z. 4, s. 977-1019; 2004, t. 9, z. 2, s. 379-429; 2006, t. 9, z. 803-838. 


\section{Dokument 1}

\section{Najczcigodniejszy Księże Rektorze! ${ }^{a}$}

Ika ${ }^{9}$ d[nia] 10/IX [1]900

Udaję się z prośbą do Księdza Rektora. Obiecałem był mieć w tym roku szereg wykładów w uniwersytecie ludowym. Prosił mię o to ten profesor, który stoi na czele (zapomniałem nazwisko). Otóż nic dotąd nie mam nagotowanego, więc by dotrzymać przyrzeczenia na ten rok musiałbym nakładać pracę po przyjeździe do Lwowa, właśnie więc wówczas, gdy będzie najgorętszy czas wyborczy i najważniejszy dla organizacji. Jest to doprawdy za wiele na stan mego zdrowia, zwłaszcza skoro dodam kłopoty i pertraktacje z „Ruchem” ${ }^{10}$. Może by tak Ksiądz Rektor od siebie mógł mu przedłożyć tę sprawę i przynajmniej odwłokę pozyskać? Byłaby to wielka łaska dla mnie. Co do mego brata $^{11}$ to się wyjaśnia sprawa z gazetą i najprawdopodobniej uda mu się powrócić do Rosji, więc projekt, który miałem upada. Nie potrzebuję chyba osobno prosić Księdza Rektora o weksel w tej sprawie całej, w której nie znający rzeczy mógłby mię łatwo pomówić o jaką prywatę, od której Bóg świadkiem tak dalece jestem. Dziś już wyjeżdżam, bo mię kusi kongres uczonych w Monachium, który się rozpoczyna w poniedziałek. Nie wiem czy to będzie warto, ale niech będzie jak będzie. Żądane przez Księdza Rektora materiały socjalne do listu pasterskiego ${ }^{12}$ zbieram, niech Ksiądz Rektor sobie z nimi zrobi, co uzna za stosowne - weźmie albo odrzuci. Francuskie rzeczy są niektóre dobre. Trochę mię psuje przyszły Arcybiskup - Księże Rektorze, bo mi się wciąż zdaje, że to samo co było wyskokiem serca wobec Księdza Bilczewskiego, wyglądać może na

${ }^{9}$ Ika - miejscowość wypoczynkowa nad Adriatykiem w granicach dzisiejszej Chorwacji.

a Powyżej aneks pisany ręką ks. Józefa Bilczewskiego: „Odpowiedź na mój list, w którym wyraziłem zdanie, że lepiej, aby brat Ks. Teodorowicza, nie wracał do redakcji dziennika”. Ponadto obcą ręką, niebieską kredką napisane jest nazwisko: „Teodorowicz”. List pisany jest na podwójnej, nieliniowanej kartce formatu kieszonkowego. Znak wodny przedstawia bogato zdobiony napis: „Original Fiume - Mitt”.

${ }^{10}$ Właściwie: „Ruch Katolicki” - organ prasowy Stronnictwa Katolicko-Narodowego. Pismo ukazywało się w 1. 1897-1901 we Lwowie. Wydawcą był Stanisław Starowieyski, funkcję redaktora pełnił Stanisław Waśniewski, jego zastępcy - Włodzimierz Zawadzki, sekretarza - Franciszek Morawski. Spółkę wydawniczą tworzyli: ks. Zygmunt Lenkiewicz, Andrzej Romaszkan i Leszek Prus Wiśniowski. W kwietniu 1899 r. do komitetu redakcyjnego należeli: Adam ks. Sapieha - przewodniczący, ks. Józef Bilczewski, ks. Jan Gnatowski, ks. Józef Teodorowicz, prof. Bronisław Dembiński, Tadeusz Pilat, prof. Maksymilian Thullie. Redakcją kierował Włodzimierz Zawadzki przy pomocy dr. Jana Paygerta. Pismo miało ok. 2000 prenumeratorów. Początkowo w 1897 r. ukazywało się jako tygodnik, potem jako dziennik. C. Lechicki, Z dziejów prasy, s. 166-167; tenże, Polskie czasopiśmiennictwo katolickie, s. 35; Polskie czasopisma religijno-społeczne w XIX wieku. Materiaty do katalogu, pr. zbior., Warszawa-Lublin 1988, s. 651; J. Jarowiecki, Prasa lwowska w latach 1864-1918. Bibliografia, Kraków 2002, s. 369-370.

11 Teodorowicz Mieczysław Dawid (1870-1909), brat abp. Józefa Teodorowicza, redaktor „Przedświtu”, zmarł 1 XII 1909 r., pochowany na cmentarzu w Stanisławowie. Informacja własna; informacja pisemna mgr. Tomasza Krzyżowskiego, Kraków 4 I 2017 r.

12 Aluzja do przygotowywanych przez nominata-arcybiskupa lwowskiego Józefa Bilczewskiego listów pasterskich na inaugurację pontyfikatu. Zobacz ich treść: J. Bilczewski, List pasterski do duchowieństwa archidiecezji w dniu konsekracji i intronizacji, Lwów 20 stycznia w dniu N[ajświętszego] Imienia Jezus 1901, w: tenże, Listy pasterskie i mowy okolicznościowe, Mikołów-Warszawa 1908, s. 7-19; tenże, List pasterski do wiernych archidiecezji w dniu konsekracji i intronizacji, Lwów 20 stycznia 1901, w: tenże, Listy pasterskie i mowy okolicznościowe, Mikołów-Warszawa 1908, s. 23-40. 
mieszanie się w nie swoje wobec Arcybiskupa B[ilczewskiego]. Tak było z tą drobną pracą. Wprawdzie jest ona tylko materialną stroną rzeczy i wprawdzie Ksiądz Rektor tego żądał, a jednak już mię ten skrupuł prześladował. Tak samo dzieje się z pisaniem listu. Proszę darować, że tak szczerze mówię, co myślę, ale sama natura tę odmianę za sobą przynosi i przynieść musi. Ksiądz Rektor zatem z pewnością na tym mi nie stracił, ale mnie jak mówię to trochę psuje.

Najgorętsze wyrazy czci załączam

Ks. Teodorowicz

\section{Dokument 2}

Najczcigodniejszy Księże Rektorze! ${ }^{\mathrm{a}}$

Ika dnia 6, p[oczta] Jeici

Szkoda, wielka szkoda, że Ksiądz Rektor na Wiedeń nie wracał. Zmartwychwstańcy ${ }^{13}$ oczekiwali i we Wiedniu o przybyciu wiedzieli. Zaś powrót z kąpiel nie zwraca uwagi. Ale stało się. Otóż co do nominacji nie ma żadnej wątpliwości. Tak słyszałem we Wiedniu, a i Ks. Biskupowi Weberowi ${ }^{14}$ mówił o tym namiestnik, jako o fakcie dokonanym. Tak mi pisał Ks. Sapieha ${ }^{15}$. Jest jedna czy nie mała kwestia, która nominację może

a Powyżej obcą ręką dopisana jest data: „1900”. List pisany jest na dwóch nieliniowanych kartkach formatu kieszonkowego ze znakiem wodnym przedstawiającym napis: „Bombay Paper” i literę „F”. Brak pełnej datacji.

${ }^{13}$ Tzw. Misja Wiedeńska Księży Zmartwychwstańców swymi początkami sięgała 18 VII 1897 r. Powstała ona przy kościele pw. św. Krzyża w Wiedniu (Rennweg 5a) z myślą o miejscowej Polonii. Jej twórcami byli: ks. Franciszek Lutrzykowski, br. Tomasz Roszyk, br. Andrzej Kaczeński i br. Adam Sikora. B. Micewski, Osobowy i terytorialny rozwój Zgromadzenia Zmartwychwstania Pańskiego w: Zmartwychwstańcy w dziejach Kościoła i narodu, red. Z. Zieliński, Katowice 1990, s. 47.

${ }^{14}$ Weber Józef (1856-1918), święcenia kapłańskie w 1873 r. we Lwowie, dr teologii, 1875-1895 kanclerz Konsystorza Metropolitalnego ob. łac. we Lwowie, 1895-1906 biskup pomocniczy archidiecezji lwowskiej, rektor Seminarium Duchownego we Lwowie, kanonik Kapituły Metropolitalnej i wikariusz generalny; 15 IV 1901 r. mianowany arcybiskupem tytularnym Darnia. Wskutek oszczerczej kampanii brukowej prasy lwowskiej zrezygnował w 1906 r. ze wszystkich urzędów w archidiecezji i wyjechał do Rzymu, gdzie wstąpił do Zgromadzenia Księży Zmartwychwstańców. W 1909 r. został wysłany do Ameryki Północnej: 1909-1914 mistrz nowicjatu w Kanadzie i delegat generała (1910-1914). Później udał się do USA, gdzie pełnił funkcję delegata generała i superiora Kolegium Świętego Stanisława Kostki w Chicago (1914-1918). P. Nitecki, Biskupi Kościoła w Polsce. Stownik biograficzny, Warszawa 1992, s. 219 (informacje nieścisłe i błędne); AALK, bsygn., Listy abp. J. Webera do abp. Józefa Bilczewskiego 1906-1918, teczka: Listy do abp. J. Bilczewskiego, rps; AJWK, bsygn., Listy abp. J. Webera do generała Księży Zmartwychwstańców ks. Jana Kasprzyckiego 1906-1918, kopie.

${ }^{15}$ Sapieha Adam Stefan (1867-1951), święcenia kapłańskie w 1893 r. we Lwowie, dr prawa kanonicznego, 1894-1895 wikariusz w Jazłowcu, 1895-1897 studia w Rzymie, 1897-1901 wicerektor Seminarium Duchownego we Lwowie, 1902-1911 kanonik Kapituły Metropolitalnej tamże, 1906-1911 sekretarz osobisty Piusa X w Rzymie; 24 XI 1911 r. prekonizowany biskupem krakowskim, 14 XII 1925 r. mianowany arcybiskupem, 18 II 1946 r. - kardynałem. Księga Sapieżyńska, red. J. Wolny, t. 1-2, Kraków 1982-1986, passim; J. Wołczański, Adam Stefan Sapieha w korespondencji z biskupami Galicji (Małopolski), s. 94-99; Kardynat Adam Stefan Sapieha. Książę niezłomny, red. J. Urban, Kraków 2014, passim. 
opóźnić. O tym wiem z najautentyczniejszego źródła we Wiedniu. Oto Gołuchowski ${ }^{16}$ uparł się ażeby przed nominacją Księdza Rektora utworzyć biskupstwo w Tarnopolu ${ }^{17}$. Literalnie może uparł się, bo ani Hartel ${ }^{18}$, ani Piętak ${ }^{19}$ nie mogą mu tego wybić z głowy. Gdy byłem na wyjezdnym, miał być u niego Hartel raz jeszcze. O wyniku wszakże nie wiem, gdyż wyjechałem. Sądziłem, że Ksiądz Rektor przybędzie i coś zrobi w tej sprawie. Znosiłem się z Ks. Sapiehą naradzając się co by zrobić, aby przeszkodzić nieszczęśliwemu planowi dzielenia diecezji i ociągania nominacji. On sądzi, żeby najlepiej było ogłosić w gazetach, że diecezja ma być kreowana w celach agitacji na wschód, a ta notatka wystarczy, by Rzym się temu sprzeciwił. Mogę to zrobić. Szkoda, że w Rzymie nie ma nikogo, kto by przedstawił nonsens tego projektu. Ale wracając do rzeczy. Gołuchowski bruździ przez ociąganie. Coś się w tych dniach musiało w tej sprawie stać bardziej definitywnego, ale trzeba być we Wiedniu by się dowiedzieć. Gdyby też Ksiądz Rektor z Krakowa palnął sobie podróż na tydzień do Iki przez Wiedeń? We Wiedniu nie potrzeba wcale być u ministra ani urzędniczej figury. Wystarczy zupełnie zajechać do zmartwychwstańców i kazać się zapowiedzieć do radcy Romera ${ }^{20}$, który pracuje u Piętaka. I przyjść do niego pod pretekstem podziękowania, że dla „Ruchu” pracuje nad usunięciem Zawadzkiego ${ }^{21}$ i przydzieleniem go do biura korespondencyjnego we Wiedniu

${ }^{16}$ Gołuchowski Agenor (1849-1921), hrabia, właściciel dóbr w Galicji Wschodniej, 1872-1880 attache ambasady austriackiej w Berlinie, 1880-1887 pracownik ambasady w Paryżu, 1887-1894 poseł nadzwyczajny i minister pełnomocny w Bukareszcie, 1887-1906 austriacki minister spraw zagranicznych. Po $1906 \mathrm{r}$. wycofał się z życia politycznego. H. Jankovsky, Graf Agenor Maria Adam Gotuchowski der Jüngere und seine Balkanpolitik, w: Polacy w austriackim parlamencie. W 130. rocznicę Koła Polskiego, red. W. Kucharski, Lublin-Wiedeń 1997, s. 163-184; J. S. Dunin-Borkowski, Austriaccy radcy tajni w Galicji, Lwów 1901, s. 30-32.

17 Diecezja rzymskokatolicka w Tarnopolu miała powstać przez wydzielenie jej z ówczesnej archidiecezji lwowskiej. Idea ta powracała wielokrotnie za pontyfikatu abp. Józefa Bilczewskiego (1900-1923) i jego następcy abp. Bolesława Twardowskiego (1923-1944), wysuwana przez czynniki państwowe. Obaj hierarchowie skutecznie ją jednak zwalczali.

${ }^{18}$ Hartel Wilhelm von (1839-1907), językoznawca, w 1866 r. habilitował się na Uniwersytecie Wiedeńskim, w 1869 r. prof. nadzwyczajny, w 1872 r. prof. zwyczajny, w roku akad. 1890/91 rektor Uniwersytetu Wiedeńskiego, 1891-1896 dyrektor Biblioteki Dworu Cesarskiego w Wiedniu, w 1896 r. objął kierownictwo sekcji ds. szkół wyższych i średnich w Ministerstwie Wyznań i Oświaty, 1900-1905 minister Wyznań i Oświaty. G. Baader, Hartel Wilhelm August Ritter von, w: NDB, Bd. 7, red. zbior., Berlin 1966, kol. 707-709.

${ }_{19}$ Piętak Leonard (1841-1909), dr praw, w 1869 r. zastępca prof. prawa handlowego i wekslowego na Uniwersytecie Lwowskim, w 1870 r. prof. nadzwyczajny, 1876 r. prof. zwyczajny prawa handlowego, wekslowego i rzymskiego tamże, w roku akad. 1878/79, 1885/86 i 1890/91 dziekan Wydziału Prawa i Umiejętności Politycznych, w roku akad. 1881/82 i 1888/89 rektor Uniwersytetu Lwowskiego; od 1886 r. członek Rady Miejskiej Lwowa, 1893-1909 poseł do austriackiej Rady Państwa, członek i wiceprezes Koła Polskiego w parlamencie austriackim, od 20 X 1899 r. wiceprezydent Izby Posłów w Wiedniu, od 1907 r. dożywotni członek Izby Panów, 19 I 1900 r. mianowany ministrem bez teki dla Galicji. W. Hahn, Kronika Uniwersytetu Lwowskiego, cz. 2: (1898/9-1909/10), Lwów 1912, s. 250; J. Buszko, Polacy w parlamencie wiedeńskim 18481918, Warszawa 1996, passim.

${ }^{20}$ Romer Karol Adam (1885-1938), polski dyplomata, 1909-1914 i 1916-1918 urzędnik wiedeńskiego Ministerstwa Spraw Zagranicznych, 1914-1916 żołnierz armii austriackiej, 1919-1927 pracownik polskiego MZS na placówce w Wiedniu, 1927-1938 dyrektor Protokołu Dyplomatycznego MSZ w Warszawie. A. Szklarska-Lohmannowa, Romer Karol Adam, w: PSB, t. 31, red. zbior., Wrocław 1988-1989, s. 649-650.

${ }^{21}$ Zawadzki Włodzimierz (1863-1928), członek redakcji „Gazety Narodowej”, profesjonalny dziennikarz, od II kwartału 1898 r. prowadził kierownictwo redakcji „Ruchu Katolickiego”. C. Lechicki, Z dziejów prasy, s. 167. 
i prosić go o poparcie sprawy. Z tego by się wywiązała dyskusja. A Romer daleko lepiej wie o wszystkim niż Piętak, który jest poczciwa, ale skończona fujara. Wyjazd zaś nad morze dla odwrócenia uwagi jest pretekstem dla jazdy. Tu zaś uradzilibyśmy, co dalej począć by projektowi podziału przeszkodzić. Mógłbym nawet gdyby tego potrzeba pojechać do Rzymu. Czy by też w ogóle nie dało się Księdzu Rektorowi dać przez kogo zastąpić w obowiązkach Rektora ${ }^{22}$ ? Przynajmniej do czasu inauguracji - notabene ${ }^{23}$ gdyby aż tak długo było potrzeba czekać? Lecz jeśli nie, to proszę się zastanowić nad projektem, który podałem puszczenia się przez Wiedeń nad morze. Można by np. wyjechać $\mathrm{w}$ niedzielę po obiedzie blitzem ${ }^{24}$ do Wiednia, przez poniedziałek być tam i załatwić, a w poniedziałek wieczór o 8 wyjechać sobie na Südbahn ${ }^{25}$ nająć Szlafwagen ${ }^{26}$, a rano już stanąć tu. Więc oczekuję.

Cieszę się uznaniem dla „Ruchu”, choć jeszcze arcywiele mu niedostaje do ideału. Swoją drogą sytuacja z „Ruchem” strasznie powikłana. Aferzyści krakowscy tylko czyhają na chwilę, kiedy ja sam wyrzucę Zawadzkiego, by mogli spaść na „Ruch” i po swojemu gospodarzyć. A swoją drogą ani centa nie dają na pismo. Stąd rodzi się sytuacja nie do pozazdroszczenia. Tu czuwać przed napadem krakowskich (Morawski Franciszek ${ }^{27}$ już zjeżdżał do Lwowa), tu rugować Zawadzkiego, tu składać nowy gabinet współpracowników. a w dodatku nie mieć pieniędzy. Przyjąłem paru współpracowników, których płacę, ale notabene ostatkami gonię. Myślę, że jak tylko Celsissimus ${ }^{28}$ będzie nominowany to będzie najlepiej, gdy np. Ks. Sapieha na swe imię wystawi weksel, który by później przyszedłszy do pieniędzy Ksiądz Rektor w ratach spłacał. Nie widzę innego wyjścia dla pisma, które dopiero teraz właściwą rację bytu u nas mieć poczyna.

Co do mego brata myślałem go przeznaczyć do administracji i agitacji. Madurowi$\mathrm{Cza}^{29}$ zaś do w[e]nętrznego technicznego zarządu. Madurowicz bowiem jest niedołęgą w rzeczach praktycznych, nawet niemożliwy w kontakcie ze stronami, a ja znów muszę

${ }^{22}$ Ks. prof. Józef Bilczewski został wybrany rektorem Uniwersytetu Lwowskiego na rok akad. 1900/01. M. Tarnawski, Arcybiskup, s. 16-25.

${ }^{23}$ Łac.: nawiasem mówiąc.

${ }^{24} \mathrm{Z}$ niem.: Blitz - błyskawica, piorun. Tu w znaczeniu: pociąg błyskawiczny.

${ }^{25}$ Właściwie niem.: Südbahnhof - dworzec południowy.

26 Właściwie niem.: Schlafwagen - wagon sypialny.

${ }^{27}$ Morawski Franciszek (1868-1938), studiował prawo, filozofię, ekonomię i rolnictwo; gospodarował w majątkach pow. Jaworów w Galicji, po czym osiadł we Lwowie. W 1897 r. redagował tygodnik „Ruch Katolicki”, tegoż roku mieszkał we Wiedniu, a od 1898 r. osiadł w Wielkopolsce gdzie redagował „Kurier Poznański” (1900-1903). Uprawiał pisarstwo polityczne. W l. 1910 i 1912 został wybrany do Reichstagu, a w 1913 r. do sejmu pruskiego, w 1917 r. został członkiem pruskiej Izby Panów; w l. 1918-1932 przebywał w Paryżu, a ostatnie lata życia spędził w Krakowcu (Małopolska Wschodnia). Deklarował się jako zwolennik sojuszu Francji, Polski i Austrii oraz identyfikował się z ideologią stańczyków i Piłsudskiego. A. Galos, Morawski Franciszek, w: PSB, t. 21, red. zbior., Wrocław 1976, s. 716-717.

${ }^{28}$ Łac.: najdostojniejszy, najwspaniałomyślniejszy.

${ }^{29}$ Madurowicz Maurycy - dr, urzędnik Wydziału Krajowego we Lwowie, członek Stronnictwa Katolicko-Narodowego, współpracownik „Ruchu Katolickiego”, redaktor „Przedświtu”. Członek Rady Okręgowej Chrześcijańskiej Demokracji we Lwowie, radny miasta Lwowa, sekretarz Konferencji św. Anny Towarzystwa św. Wincentego a Paulo, członek Komitetu Związku Katolicko-Społecznego we Lwowie. J. Wołczański, Ksiadz Szczepan Szydelski (1872-1967). Polityk i działacz społeczny, Kraków 1992, passim. 
koniecznie mieć kogoś, co by był duszą strony praktycznej pisma gdyż sam nie jestem do tego, a potem nie mogę się zbyt absorbować drobiazgami. Ja jak widzę z mej dotychczasowej redakcyjnej praktyki, takiego jakiego człowieka mieć muszę .

\section{Dokument 3}

\section{Najczcigodniejszy Księże Rektorze! ${ }^{\mathrm{a}}$}

Mam już odpowiedź z Wiednia ze samego źródła. Na szczęście bardzo pomyślna. Sądzę z niej, że ogłoszenie nominacji kwestią już jest bardzo niedługiego czasu. List załączam tutaj. Tak okropnie wszak list pisany, że Ksiądz Rektor podobny bardziej do $[\ldots]^{\mathrm{b}}$ niż do siebie. Ale nic nie szkodzi. Rzecz jest. Żałuję dziś mocno, że wysłałem ów zwinięty mój list Księdzu Rektorowi, ale już się stało. Co do poruszonej w ostatnim liście Księdza Rektora kwestii listu pasterskiego i ja tego samego byłbym zdania, że na formie zależy najwięcej. Czy by nie było dobrze, by sobie Ksiądz Rektor przeczytał list ${ }^{30}$ Ks. Szeptyckiego ${ }^{31}$ ? Nie dla wzoru, bo w liście tym Ksiądz Szeptycki za mało, nic prawie o Kościele nie mówi, a dla chleba powszedniego zdaje się zapominać o chlebie duchowym. Jednak ten list jego jest jakby z jednego ulany i to mi się w nim podoba. Najsilniejsze zrobi wrażenie list jeśli jedną myśl przedstawi. Ksiądz Rektor już ją ma, mianowicie o prądach społecznych. Czy by nie było dobrze wykazać w Kościele lekarstwa i siłę na te właśnie społeczne prądy, a kapłanom ich obowiązki wobec nich? Oczywiście akcentując między liniami prąd demokratyczny, ale nie nazywając go po imieniu, bo to u wielu zrobi złą krew. Jeśliby takie same myśli zasadnicze były Księdza Rektora, w takim razie mógłbym tu parę pięknych myśli jako substrat wyciągnąć do rzeczy, które mam pod ręką, albo je wprost przesłać Księdzu Rektorowi. A tymczasem szlę najserdeczniejsze pozdrowienie, z najgłębszą czcią i szacunkiem

Ks. Teodorowicz

Ika, d[nia] 8 X [1]900

b Brak zakończenia listu.

a Powyżej obcą ręką niebieską kredką nazwisko: „Teodorowicz” i data: „1900”. List pisany jest na kartce formatu kieszonkowego z widocznym znakiem wodnym: „Bombay Paper” i literą „F”.

b Wyraz nieczytelny

${ }^{30}$ Pastyrśke posłannija Stanislawiwśkogo epyskopa Andreja Szeptyćkogo do wirnych «Chrystijanśka robota». Stanisławiw 2 VIII 1899 r., w: Mytropotyt Andrej Szeptyćkij: Żyttija i dijalnist. Dokumenty i materiaty 1899-1994, t. 2, cz. 1, red. A. Krawczuk, Lwiw 1998, s. 1-16.

31 Szeptycki Andrzej (1865-1944), dr praw, dr teologii, po zmianie obrządku łacińskiego na greckokatolicki wstąpił w 1888 r. do nowicjatu oo. Bazylianów w Dobromilu, a potem odbył studia filozoficzno-teologiczne w Krakowie; święcenia kapłańskie w 1892 r. w Przemyślu w ob. greckokat. W 1896 r. został ihumenem klasztoru św. Onufrego we Lwowie oraz profesorem teologii w bazyliańskim studium w Krystynopolu, 1899-1900 biskup w Stanisławowie, 1900-1944 arcybiskup metropolita lwowski. Metropolita Andrzej Szeptycki. Studia i materiaty, red. A. A. Zięba, Kraków 1994, passim; K. Korolewśkyj, Mytropotyt Andrej Szeptyćkyj (1865-1944), Lwiw 2014, passim.

c Zgodne z oryginałem. 


\section{Dokument 4}

Ika, wtorek

Najczcigodniejszy Księże Rektorze! ${ }^{\mathrm{a}}$

Musiałem ja nabazgrać co się wlazło, skoro Ksiądz Rektor co innego z mego listu wyczytał, niż ja napisać chciałem. Proszę darować memu pośpiechowi. Uważam, że Ksiądz Rektor sądzi jakoby coś jeszcze było do zrobienia w sprawie nominacji i zastrzega się, by nic nie robić, ja zaś wyszedłem z tego, że nominacja to dziś już przesądzona i pewna, a chodzi tylko o zapobieżenie rozćwiartowaniu diecezji, które wiele nie w porę przychodzi, a zrodziło się w głowie teoretyka tej miary, co Piniński ${ }^{32}$, nie ma zaś kwestii o to, że tym panom o nic innego nie chodzi jak tylko o Rusinów. W dodatku tę okoliczność przeciąga niesłychanie ogłoszenie faktyczne nominacji. Otóż wyszedłem z tego, że Ksiądz Rektor, a nikt już w sprawie zasadniczej nie może sytuacji polepszyć, bo jest najlepsze i pewne. Natomiast pewną rzeczą jest Księdza Rektora już dzisiaj jako de fac$t o^{33}$ nominowanego coś bodaj po Wiedniu zrobić w sprawie, w której ci panowie chcą się nieprawnie rządzić bez gospodarza. Naturalnie, że nie można nic uczynić bezpośrednio, ale wiele by można pośrednio. Zresztą sądzę, że to się da zrobić, nie mieszając w to wcale a wcale nawet pośrednio Księdza Rektora. Z Wiednia będę miał wiadomości za parę dni w całej sprawie i z nimi się podzielę z Księdzem Rektorem.

Dziękuję za list serdeczny, który mnie ośmiela do wynurzenia się w kwestiach poruszanych przez Księdza Rektora. Uważam najpierw zawsze brzmienie nuty serca Księdza Rektora, strunę tej czystej pokory, która się niegodną być sądzi. Znam aż nadto dobrze z tej strony Księdza Rektora i wiem, że chociaż ani sam palcem nie ruszył w sprawie swej kandydatury, a nikomu zgoła tej godności nie zawdzięcza prócz swoim przymiotom i wybraństwu Bożemu ${ }^{34}$

a Powyżej ołówkiem obcą ręką dopisana data: „1900”. List pisany jest na pięciu, numerowanych cyframi rzymskimi, kartkach formatu kieszonkowego. Znak wodny przedstawia napis: „Bombay Paper” i literę „F”. Brak datacji i autografu autora.

${ }^{32}$ Piniński Leon (1857-1938), dr praw, w 1886 r. habilitował się na Uniwersytecie Lwowskim, 1886-1890 docent prywatny prawa rzymskiego, w 1891 r. prof. zwyczajny i kierownik Katedry Prawa Rzymskiego Uniwersytetu Lwowskiego (1892-1898), w 1903 r. został członkiem czynnym Akademii Umiejętności w Krakowie, 1889-1898 poseł do Rady Państwa, należał do grona przywódców Koła Polskiego. Od 1894 r. zasiadał w Sejmie Galicyjskim, 1898-1903 namiestnik Galicji. Prowadził walkę z ukraińskim ruchem narodowym i socjalistami, był dożywotnim członkiem Izby Panów Rady Państwa, członkiem Rady Szkolnej Krajowej we Lwowie (1904-1920). Od 1903 r. jako prof. honorowy prowadził wykłady z prawa rzymskiego i karnego na Uniwersytecie Lwowskim. Jako przedstawiciel tzw. autonomistów należał do Stronnictwa Prawicy Narodowej. Był członkiem Naczelnego Komitetu Narodowego w 1914 r., rok później włączył się w nurt pracy Książęco-Biskupiego Komitetu we Lwowie. Od 1918 r. zerwał z polityką, poświęcając się nauce, muzyce i sztuce. J. Zdrada, Piniński Leon, w: PSB, t. 26, red. zbior., Wrocław 1981, s. 332-337.

${ }^{33}$ Łac.: $w$ rzeczywistości.

${ }^{34} \mathrm{Z}$ nadprzyrodzonego punktu widzenia, autor listu miał rację, widząc w elekcji ks. J. Bilczewskiego rękę Opatrzności. Ale niebagatelną rolę w tym procesie odegrały też ludzkie czynniki, w tym namiestnik Galicji hr. Leon Piniński. Pod jego wpływem przeprowadzono jednomyślny wybór ks. Bilczewskiego na urząd rektora Uniwersytetu Lwowskiego w roku akad. 1900/01. Krok ten miał ułatwić dalsze poczynania. W sondażu przeprowadzonym przez namiestnika w gronie episkopatu galicyjskiego, najbardziej wpływowy hierarcha krakowski - bp Jan Puzyna wystawił ks. Bilczewskiemu pochlebną opinię, umieszczając go wśród kandydatów do sakry biskupiej, ale dopiero na dalszych pozycjach. To utwierdziło Pinińskiego w powziętych co do 
to jednak nieraz będzie się skrupulizowa ${ }^{35}$ zwłaszcza wobec starszych, a domniemanych kandydatów. Dlatego pozwolę sobie całkiem szczegółowo przejść jednego po drugim z tych, co by mogli być arcybiskupami, ażeby eksperymentalnie wykazać, że Ksiądz Rektor jedynym jest kandydatem. Gdyby mi się udało raz na zawsze te skrupuły spłoszyć czułbym się bardzo szczęśliwym.

Otóż kandydaci o których była lub mogła być mowa byli prócz Zabłockiego ${ }^{36}$ - bo nad tym się rozwodzić nie będę - Ks. Wałęga ${ }^{37}$, Lenkiewicz ${ }^{38}$, Ks. Biskup Weber.

O Księdzu Wałędze trudno mi doprawdy pisać, bo go nie tylko cenię wysoko, ale szczerze jak przyjaciela kocham. Ale wręcz oświadczyć muszę, że to nie jest kandydat na metropolitę. Dlaczego? Zapewne ma on wysokie niepospolite cnoty kapłańskie. Ma zdolności, wielką miłość Kościoła i sprawy Bożej, zdolność do poświęcenia siebie i wszystkiego gdzie potrzeba i to nie na dzień, ale na długo, na zawsze, on ma to wszystko, a jednak - wręcz twierdzę, że to nie jest materiał na biskupa. Oto przede wszystkim dlatego, że jego umysł mimo całej swej zdolności, podobny do tej latarki, która jedne strony niesłychanie jasno oświeca, a drugie na zawsze ciemnymi zostawia. Ksiądz Rektor sam słyszał jego zdanie: „z tą inteligencją nie da się nic zrobić, niechże idzie

kandydata decyzjach. W czasie rozmowy w Wiedniu latem 1900 r. z cesarzem i ministrem Wyznań i Oświaty Wilhelmem Hartlem, przedstawił on kandydaturę ks. Bilczewskiego na stolicę łacińskich arcybiskupów lwowskich, uzyskując z ich strony pełną akceptację. Dnia 7 VIII 1900 r. Piniński zawiadomił o tym duchownego, bawiącego wówczas na wakacjach w Nanheim. Ks. Bilczewski listem z 11 sierpnia t.r. przedstawił namiestnikowi swoje zastrzeżenia, które wywołały odwrotny od zamierzonego skutek, utwierdzając go w słuszności co do powziętych kroków. Dnia 13 sierpnia t. r. Piniński postawił ks. Bilczewskiego przed faktem dokonanym, tłumacząc mu, że ani cesarz, ani Kuria rzymska nie zgodziłyby się już na odmowę przyjęcia przezeń nominacji. M. Tarnawski, Arcybiskup, s. 21-24.

${ }^{35}$ Określenie przestarzałe: przeżywać skrupuły.

${ }^{36}$ Zabłocki Feliks (1830-1911), święcenia kapłańskie w 1852 r. we Lwowie, dr prawa kanonicznego, prefekt studiów w Seminarium Duchownym we Lwowie, 1860-1872 zastępca prof. prawa kanonicznego na Wydziale Teologicznym Uniwersytetu Lwowskiego, 1873-1911 kanonik gremialny Kapituły Metropolitalnej we Lwowie, prepozyt-infułat i protonotariusz apostolski. Po śmierci abp. Seweryna Morawskiego wikariusz kapitulny archidiec. lwowskiej. J. Wołczański, Listy biskupa Leona Wałegi do arcybiskupa Józefa Bilczewskiego z lat 1900-1922, NP, t. 90, Kraków 1998, s. 199.

37 Wałęga Leon (1859-1933), święcenia kapłańskie w 1883 r. dla archidiec. lwowskiej ob. łac., dr teologii, 1884-1885 wikariusz parafii pw. św. Marcina we Lwowie; prefekt Małego Seminarium i sekretarz Sądu Metropolitalnego, 1885-1888 prefekt studiów Seminarium Duchownego we Lwowie i katecheta Męskiego Seminarium Nauczycielskiego, 1888-1891 wicerektor tegoż seminarium, 1888-1893 zastępca prof. katechetyki i metodyki na Wydziale Teologicznym Uniwersytetu Lwowskiego, $1891 \mathrm{r}$. habilitował się z teologii fundamentalnej, 1894-1897 prof. nadzwyczajny filozofii i teologii fundamentalnej, 1897-1901 kanonik gremialny Kapituły Metropolitalnej we Lwowie, 1901-1932 biskup diecezjalny tarnowski, w 1933 r. mianowany arcybiskupem tytularnym Oxyrinchus. J. Wołczański, Listy biskupa Leona Watęgi, s. 181-386.

${ }^{38}$ Lenkiewicz Zygmunt (1845-1913), święcenia kapłańskie w 1867 r. we Lwowie, dr teologii, 1873-1875 adiunkt na Wydziale Teologicznym Uniwersytetu Lwowskiego, 1879 r. habilitacja na UJ w Krakowie, 18811891 prof. zwyczajny teologii moralnej tamże oraz 1883-1887 wykładowca języków semickich, 1891-1913 kanonik gremialny Kapituły Metropolitalnej we Lwowie. Był wydawcą i redaktorem czasopism katolickich we Lwowie: „Tygodnika Katolickiego”, „Gazety Kościelnej”, „Adoracji Przenajświętszego Sakramentu”; 19121913 rektor Seminarium Duchownego we Lwowie. Był profesorem i wielkim protektorem ks. Bilczewskiego od czasów studenckich, a potem jego wiernym przyjacielem. Abp Bilczewski uważał go za najzdolniejszego kapłana archidiec. lwowskiej. AALK, bsygn., J. Bilczewski, Dziennik, s. 288-290; C. Lechicki, Lenkiewicz Zygmunt w: PSB, t. 17, red. zbior., Wrocław 1972, s. 59-60. 
na zatracenie”, „przychodzi socjalizm? Dobrze - niech nauczy ich!”, etc. Człowiek ten jest dobry do społeczeństwa świętych, ale nigdy dla takiego jak nasze. Te zasadnicze jego pojęcia sprawiłyby, że zostawszy biskupem, stworzyłby on rozłam zupełny między społeczeństwem a sobą, a powoli nawet i klerem. Wszakże w seminarium był po prostu niecierpiany. Proszę dziś wspomnieć jego imię w seminarium, a zobaczy Ksiądz Rektor. Cóżby więc dopiero [by] było gdyby ten człowiek został biskupem i to biskupem w tej tak krytycznej chwili dla naszego społeczeństwa? Zagryzłby on samego siebie, a sprawę Bożą zaprzepaściłby zupełnie.

A Ksiądz Lenkiewicz? Drogi, kochany, szlachetny ksiądz Lenkiewicz. Pełen niepospolitych i wprost niezwyczajnych zdolności i złotego, szlachetnego serca. To wszystko prawda, ale to nie kandydat na biskupa. Przede wszystkim dlatego, że rzecz dziwna a prawdziwa: ten człowiek nie ma swego zdania, choć ma o wszystkim zdanie. Nic łatwiejszego jak go [... $]^{\text {b; }}$ dziś tak, jutro inaczej. Ostatni ma u niego zawsze słuszność, choć mu się zdaje, że to on tak osądził. Taki drobiazg, np. odgrażał się wciąż na tego nowego dyrektora teatru, że będzie przeciw niemu. Na godzinę przed głosowaniem zmienił się i bez przyczyny, i głosował za nim, i tak w nieskończoność. Cóż to za biskup? Rządziliby wszyscy, czyli byłaby anarchia. Przy tym przy całej zdolności księdza L[enkiewicza] jego suma poglądów en block ${ }^{39}$ wzięta, już jest trochę przestarzała odnośnie do dzisiejszych prądów, przy tym za wiele w nich ducha świata i rachub świata. Lecz jeśliby poglądy były jak najlepsze, to jak to Ksiądz Rektor aż nadto dobrze wie, jego wola paraliżem tknięta. On by nic nie zdziałał.

Zostaje Ksiądz Biskup Weber. Jest to niezaprzeczalnie święty człowiek, rozumiejący sercem ducha czasu i potrzeby Kościoła, choć może za mało mający praktycznego zmysłu. Lecz znowu to człowiek zbyt żyjący życiem wewnętrznym, by zdołał rozwinąć potrzebną działalność zewnętrzną.

Zostawałby jeden jedyny kandydat obok Księdza Rektora - to jest Ks. Sapieha. Ten człowiek rzeczywiście posiada cnoty biskupie, orientacje olbrzymie, zmysł wyrobiony praktyczny, znajomość ludzi i stosunków, i to, co bym nazwał bon sens ${ }^{40} \mathrm{w}$ sprawach Kościoła. Przy tym szerokie serce i umysł. Ale najpierw jego kandydatura by nie przeszła, a po wtóre ja nie wiem, czy by on łożył wszystkie pieniądze w sprawy Kościoła. Nie mówię ni nie, ni tak, tylko nie wiem.

Pozwoli mi Ksiądz Rektor, że teraz bez cienia pochlebstwa zregestruję kwalifikacje Księdza Rektora. Nie mówię już o darach umysłu, ale serca. Serce gorące, serce kapłańskie w każdym jego pulsie a takie szerokie! Kiedyś niedawno była mowa o nowych kandydatach. Kiedy mowa przyszła na Księdza Rektora jeden jezuita machnął ręką: „profesor” powiedział ze skrzywieniem. Ale ci ludzie się przekonają wkrótce jak mało Ksiądz Rektor ma wspólnego z suchym pedantyzmem bez serca. Dalej, jest u Księdza Rektora własne zdanie, dalekie od uporu niedającego się przekonać

\footnotetext{
b Tekst nieczytelny.

${ }^{39}$ Fr.: w całości.

${ }^{40}$ Fr.: dobry zmysł.
} 
Ks. Puzyny ${ }^{41}$, a nawet Ks. Wałęgi, a także od chwiejności Ks. Lenkiewicza i jego eklektyzmu. Pamiętam, że mi tak silnie utkwiło, gdy Ksiądz Rektor raz na przechadzce bronił wobec Ks. Lenkiewicza podówczas Redaktora Luegera ${ }^{42}$ i innych, a zauważyłem nieraz Księdza Rektora siłę przekonania pozbawioną ciasnoty jednostronności oporu i słabej chwiejności. Dalej tkwi w Księdzu Rektorze człowiek czynu. Od katedry rwał się niemal Ksiądz Rektor w wir życia, mimo, że tak mało na to było czasu. Tu w czynie, działaniu jest żywioł Księdza Rektora powiedziałbym bardziej jeszcze niż w nauce. A co u nas tak rzadkie, uczucie łączy się u Księdza Rektora z wytrwałością. Energia jest wytrwałą. Czego Księdzu Rektorowi nie dostaje, to nerwów jak postronki, ale te musi sobie Ksiądz Rektor sprawić choćby za drogie pieniądze, bo się inaczej przepali wkrótce. Oto zestawienie jakie sobie pozwoliłem uczynić. Niechajże Ksiądz Rektor sam osądzi bezstronnie siebie i powie czy można się cofać, pokrywając ucieczkę z pola walki wygodnym płaszczykiem, że inni są godniejsi? Błagam na wszystko niechaj Ksiądz Rektor tego nie czyni i tej pokusie nie da się zwieść, która by klęską iście była dla naszego społeczeństwa! Godność już jest nadaną, promulgacja jest kwestią czasu, proszę się tylko nie usuwać! Rozumiem aż nadto dobrze obawy Księdza Rektora. Odpowiedzialność straszna, a prace olbrzymie. Zwłaszcza arcybiskup lwowski kolosalne ma przed sobą zadanie. Najpierw zgnieść musi ostatki józefinizmu. Nie ma Ksiądz Rektor wyobrażenia ile tej choroby tkwi w najlepszym klerze. Np. samo to, że dla wielu typem dobrego biskupa jest sprężysty administrator (Zabłocki). Samo to dowodzi, że w samym ideale pasterza diecezji tkwi zaczyn józefińskiego posiewu. Bo administrator to tylko jedna zdolność, ale przecie to nie wszystko! A ci biskupi, co pomarli, a przy ogromnych majątkach nic literalnie, nic dla Kościoła nie ufundowali, czy to nie ci co walczyli z józefinizmem, ale połowicznie, bo sami dużo z niego w sobie mieli? A ci, co dziś żyją? Naturalnie, że nie ksiądz Weber, ale tak biskup Puzyna trzymający się kliki i dławiący każde żywsze tętno, czy ten zresztą apostolski człowiek, jednak w rozmachu swoim nie ma też wiele a nieświadomie z tej choroby? Od góry do dołu my te miazmata chorobliwe nosimy w sobie. A tu nie dosyć chorobę zwalczać, potrzeba jeszcze prowadzić naprzód, a prowadzić społeczeństwo w przełomowej chwili! Nie mieliśmy dotąd biskupa, który nie mówię opiekował się, ale bodaj uwagę zwrócił na ruch ludowy. Może jeden Łobos $^{43}$ ! Ale on mógł tak mało! W Księdzu Rektorze już wielu dziś widzi polskiego

${ }^{41}$ Puzyna Jan (1842-1911), święcenia kapłańskie w 1878 r. w Przemyślu, wicerektor Seminarium Duchownego i kanonik Kapituły Katedralnej tamże, 1866-1895 biskup pomocniczy archidiecezji lwowskiej i rektor Seminarium Duchownego we Lwowie, 1895-1911 biskup krakowski, w 1901 r. mianowany kardynałem. P. Nitecki, Biskupi, s. 174.

${ }^{42}$ Lueger Karl (1844-1910), polityk austriacki, od 1885 r. członek austriackiej Rady Państwa, od 1897 r. burmistrz Wiednia, przekształconego dzięki niemu w nowoczesny ośrodek miejski; w 1907 r. założył Stronnictwo Chrześcijańsko-Społeczne. G. Boin, Lueger Karl w: LThK, Bd. 6, herausg. von J. Höfer, K. Rahner, Freiburg im Br. 1986, kol. 1197.

${ }^{43}$ Łobos Ignacy (1827-1900), święcenia kapłańskie w 1851 r. w Przemyślu, ojciec duchowny w Seminarium Duchownym tamże, kanclerz Konsystorza Biskupiego i kanonik gremialny Kapituły Katedralnej, 1882-1885 biskup pomocniczy przemyski, 1885-1886 administrator diec. tarnowskiej, 1885-1900 biskup diecezjalny tarnowski. P. Nitecki, Biskupi, s. 129. 
Manninga $^{44}$, albo Kettelera ${ }^{45}$. Ksiądz Rektor odczuwa dziś te prądy, a skoro się w nie wmyśli, potrafi też ująć je w definicje praktyczne i poprowadzi nas. Z nim siłą rzeczy pójdzie episkopat z wyjątkiem jednego. Ale za tamtym kraj i społeczeństwo. Zapewne, że takie reformy przeprowadzać, nie mogąc się należycie oprzeć o kapitułę, mając do walczenia z apatią i niezrozumieniem rzeczy, to arcytrudno. Ale Bóg pobłogosławi i owoce swej pracy będzie oglądał Ksiądz Rektor niedługo! Ach, proszę darować! Dopiero teraz widzę jak się uniosłem i wiele bibuły zamazałem. Mam skrupuły czy nie należałoby zbyt może śmiałej, a całkiem bezużytecznej bazgraniny spalić, która tak jakoś pisma impetu w spokojnej wieczornej godziny nad morza brzegiem na papier niemiłosiernie się wylała. Ale już niechaj idzie. Nawet nie czytam i nie poprawiam nic, bo musiałbym wszystko podrzeć i spalić. Za parę dni napiszę, jak tylko wiadomości przyjdą, a błagam raz jeszcze niechaj się Ksiądz Rektor nie cofa!

Szczerze oddanyc

\section{Dokument 5}

\section{Najczcigodniejszy Księże Rektorze! ${ }^{\mathrm{a}}$}

Stanisławów, d[nia] 29/X [1]900

Byłem na wyjezdnym u Księdza Rektora, ale na Jego szczęście nie zastałem w domu, więc mniej nudziarstwa mojego. Korci mnie jednak zastąpić się piórem, a notabene, że w sprawie dziennika. Chodzi o rzecz drobną na pozór, ale w istocie zasadniczą, chodzi o pogląd na katolicki dziennik - p[an| Milski ${ }^{46}$ redaktor „Dziennika Polskiego” ${ }^{47}$ przerażony wieściami o obejmowaniu nowego dziennika przeze mnie pobiegł do ks. Lenkiewicza namawiając, by ten tam gdzie należy poparł jego sprawę i ofertę. Gdzie on za jakich

${ }^{44}$ Manning Henryk Edward (1808-1892), angielski kardynał i abp Westminsteru, uczestnik Soboru Watykańskiego I, autor dzieł teologicznych, prekursor zaangażowania się Kościoła w problematykę społeczną.

${ }^{45}$ Ketteler Wilhelm Emmanuel (1811-1877), święcenia kapłańskie w 1844 r. w Münster, 1844-1846 wikariusz w Beckum, 1847-1850 proboszcz w Hopsten, 1848-1849 poseł do parlamentu niemieckiego we Frankfurcie n. Menem, w 1850 r. został proboszczem w Berlinie, tegoż roku mianowany biskupem Moguncji. Był wybitnym działaczem katolicko-społecznym, twórcą niemieckiej szkoły reform społecznych. S. Fel, Ketteler Wilhelm Emmanuel, w: EK, t. 8, red. zbior., Lublin 2000, kol. 1367-1368.

c Brak autografu autora.

a Kartka formatu kieszonkowego $\mathrm{z}$ widocznym znakiem wodnym przedstawiającym ozdobny napis: „Imperial Mill”.

${ }^{46}$ Milski Aleksander (1862-1919), po studiach prawa na Uniwersytecie Lwowskim, od 1885 r. pracownik redakcji „Dziennika Polskiego” we Lwowie, w 1889 r. został właścicielem dwutygodnika humorystyczno-satyrycznego „Śmingus”; z czasem jako współwłaściciel wszedł w posiadanie „Dziennika Polskiego”, a od 1898 r. prowadził go przez kilka lat jako wydawca. Był współzałożycielem Towarzystwa Dziennikarzy Polskich we Lwowie (1893 r.), jego wiceprezesem 1913-1915 i prezesem 1915-1919. C. Lechicki, Milski Aleksander, w: PSB, t. 21, red. zbior., Wrocław 1976, s. 241-242.

47 „Dziennik Polski” - organ konserwatystów, wychodził we Lwowie w l. 1869-1916 pod redakcją Józefa Laskownickiego, Jana Lama, Henryka Rywakowicza, Józefa Rogosza, Aleksandra Vogla, Kazimierza Ostaszewskiego-Barańskiego, Henryka Cepnika, Wacława Masłowskiego, Romana Jaworskiego. W 1878 r. pismo nabył Adam ks. Sapieha, a w XX wieku stanowiło własność Aleksandra Milskiego. W 1. 1877-1878 miało 2000 prenumeratorów. Prasa polska w latach 1864-1918, red. J. Łojek, Warszawa 1976, passim; J. Jarowiecki, Prasa lwowska, s. 162-164. 
parę tysięcy przyjmie w arendę w dzienniku sprawy katolickie. Ks. Lenkiewicz nie tylko, że się na to $w$ teorii zgodził, ale był z tym u Ks. Prałata ${ }^{48}$ i Milskiego popierał. Wiem, że mię Ksiądz Rektor nie posądzi o to jakobym sądził, że się Ksiądz Rektor zawaha, ani też myślę dawać jakie wskazówki Księdzu Rektorowi. Chciałbym tylko podnieść nieznane może co do dziennika szczegóły i raz na zawsze uciąć te propozycje, które wprawdzie idei o potrzebie dziennika katolickiego nie zabijają, ale ją oziębiać mogą. Oto „Dziennik Polski" ma bardzo zaszarganą przeszłość, a potem jest przedsiębiorstwem prywatnym Pana Milskiego, który rozmaitymi pokątnymi, a nie zawsze ładnymi sztuczkami egzystencję dziennika podtrzymuje. Otóż jeśli się ma związek z takim organem to lepiej nie związywać się wcale, tym bardziej, że dziennik i za darmo przyjmuje oferty katolickie, jak przyjmuje inne. Ale gdyby nawet ten dziennik był idealnym pismem, to jeszcze wówczas trzeba całkiem nie rozumieć idei katolickiego dziennika, ażeby sądzić, że on polega na insercji w obce pismo katolickich artykułów. To tak, jak gdyby jakiemu rozczochranemu wodziwodzie sprawiano meszty eleganckie. Dziennik katolicki musi każdą wielką czy małą sprawę z pewnego punktu ogarniać, musi jej i tam nadawać swe piętno gdzie nazwy katolickiej wyczytać nie można albo gdzie w ogóle o sprawie katolickiej się nie mówi. Musi swym duchem ożywiać i przenikać wszystko. Przy tym potrzebne jest, by na program demokracji destruktywnej, kuć w sercu społeczeństwa program pozytywnej, a to się tylko uskuteczni przez dziennik. Może być, że się nie uda taki dziennik postawić, ale przynajmniej niech się nie obniża jego idea. Toteż przypomniałem ks. Lenkiewicz[owi], że on sam niedawno mówił, iż gdyby został przemyskim biskupem wszystko by dla dziennika katolickiego oddał, bo rozumie potrzebę katolickiej prasy. Po tym dictum ${ }^{49}$ Ks. Prałat znowu zmienił swe zdanie i już dziś się godzi na katolicki dziennik, ale mimo to chciałem te myśli rzucić na papier przepraszając za okropną bazgraninę.

$\mathrm{Z}$ czcią najgłębszą

Ks. Teodorowicz

Proszę list spalić.

\section{Dokument 6}

Najczcigodniejszy Księże Rektorze! ${ }^{a}$

Śmiem uczynić jedną propozycję. Teraz niemiło będzie zapewne Księdzu Rektorowi pokazywać się we Lwowie w roli poniekąd jakby dwuznacznej przed nominacją. Nikt nie będzie właściwie wiedział jak ma z Księdzem Rektorem mówić. To i innym będzie nieprzyjemne, ale przede wszystkim Księdzu Rektorowi. Więc czy by Ksiądz Rektor nie miał ochoty siąść wieczorem we Wiedniu na pociąg z Südbahnu i stanąć rano we Fiume ${ }^{50}$

${ }^{48}$ Być może chodzi o ks. Feliksa Zabłockiego, wikariusza kapitulnego archidiecezji lwowskiej po śmierci abp. Seweryna Morawskiego.

${ }^{49}$ Łac.: oświadczenie, wypowiedź.

a Tekst pisany czarnym atramentem na 3,5 stronicach czystego papieru formatu zeszytowego.

${ }^{50}$ Fiume - miasto i port nad Adriatykiem, dziś: Rijeka w Chorwacji. 
gdzie bym już oczekiwał i zawiózł do Iki? To czas jest śliczny, mieszkanie się znajdzie wygodne, ale przede wszystkim kąpiele w morzu pyszne. Już nie mówię o mojej przyjemności, ale o prawdziwym przytułku dla Księdza Rektora. Przy tym to tak miło w ciszy uroczej snuć plany przyszłych rządów, gdyż dziś już nominacja żadnej nie ulega wątpliwości. Proszę mi tylko zatelegrafować dzień i godzinę, wystarczy na adresie: Ika post Jeici. Więc czekam.

A teraz zdaję sprawę z mej misji odnośnie do „Ruchu Katolickiego”. Skłaniam się do objęcia go, jakkolwiek nie wszystkie jeszcze skrupuły ustąpiły z duszy. W każdym razie to mnie pociesza, że widzę znaczne ożywienie pisma przy małych stosunkowo staraniach; więc mam nadzieję, że rzecz pójdzie dobrze. Co do Zawadzkiego, to obiecał go umieścić w biurze prasowym Romer. Dobrze by było gdyby Ksiądz Rektor od siebie jeszcze go o to poprosił. Zawadzki gotów jest przyjąć tę posadę. Chodziło by mi jeszcze głównie o wynalezienie dla siebie człowieka w redakcji. Jak wspomniałem Księdzu Rektorowi miałem na myśli mojego brata, który posiada sprężystość, dar organizacyjny i administracyjny, a przy tym oczywiście byłby to dla mnie człowiek pewny, na którym mógłbym polegać. Mówiłem z nim o tym teraz, gdy z Rosji przybył tu na manewrab. Odpowiedział na mą propozycję, że musiałby wprzód spróbować, jak ta rzecz idzie i sam się doświadczyć czy jej podoła. Mógłby więc podobną próbę tylko wtedy uczynić, gdyby na wypadek nieudania się jej miał sobie zagwarantowane jakieś inne miejsce. Nie mógłby bowiem porzucać dotychczasowego dla swej przyszłości korzystnego miejsca bez upewnienia się co do innego. Więc jest jeszcze tu pewna trudność. Tyle na dziś. Spieszę, by list jeszcze odszedł. $Z$ całego serca pozdrawiam i raz jeszcze zapraszam.

$\mathrm{Z}$ czcią najgłębszą i szacunkiem

Ks. Teodorowicz

Ika, d[nia] [...] [1]900

\section{Dokument 7}

Najczcigodniejszy Księże Arcypasterzu! ${ }^{a}$

Lwów, d[nia] 21/XII [1]900

Spodziewałem się wszystkiego raczej jak tego rodzaju wyrzutu, który tym więcej mnie zabolał, im mniej był zasłużony. Że nie myślałem Księdza Arcybiskupa w tę sprawę mieszać i owszem zamazałem ślady wszelkie to w tym dowód najlepszy, iż oświadczyłem wręcz adwokatom, że nieprawdą jest, co mówi Zawadzki o jakiejkolwiek łączności Księdza Arcybiskupa z jego osobą. On Zawadzki bowiem utrzymywał, że Ksiądz Arcybiskup za niego zapłaci. Otóż zaprzeczając temu najkategoryczniej, przyjąłem znowu odium $^{51}$ rzeczy na siebie. Księdzu Arcybiskupowi najwyraźniej dałem do poznania, że

b Zapis zgodny z oryginałem; poprawnie powinno być: manewry.

c Dokładna data nieczytelna spowodowana przetarciem karty listu.

a Powyżej obcą ręką napisano niebieską kredką nazwisko: „Teodorowicz”. List pisany jest na podwójnej, nieliniowanej kartce formatu kieszonkowego. Znak wodny przedstawia napis: „Victoria Mote Paper”.

${ }^{51}$ Łac.: złość, nienawiść. 
„Przedświtowi”52 jest najzupełniej obojętny rezultat w tej sprawie więc jeżeli Ksiądz Arcybiskup zapłaci 3 tysiące, to chyba w celu uniknięcia szkandalub. Lecz do tego przecie wcale radzić nie myśliłem ${ }^{c}$, tym bardziej, że do rady nie mam żadnej głowy żyjąc z dnia na dzień wśród ciągłych gróźb tego człowieka, że sobie życie odbierze etc. etc. Jestem tak tym wszystkim skłócony i zmęczony, że mi nie do tego było zwłaszcza pod pierwszym wrażeniem wiadomości o oszustwie. Co do adwokata, to i przecie są różne sposoby porozumienia się z nim. Adwokat zaś Schurr ${ }^{53}$ członek spółki „Ruchu”, człowiek pewny, mógłby wziąć pieniądze, a sprawę z Zawadzkim załatwić w imieniu spółki. I to mi się wydaje być rzeczą najwłaściwszą. Co się tknie wydania pieniędzy, to przecie była o tym mowa, że może przyjdzie wydać na „Ruch” parę tysięcy. Tym datkiem można by Zawadzkiemu zamknąć usta raz na zawsze zmuszając go do podpisania jakiego rewersu i przymusić go też do zwinięcia „Ruchu”. Jest to jak na to wcale niewielka suma. Ale jeśli Ksiądz Arcybiskup inaczej sądzi to i dobrze. Nic mi na tym dziś zupełnie nie zależy, ale dodaję raz jeszcze, że na wyrzut zupełnie sobie nie zasłużyłem. Listy otrzymuję od Księdza Arcybiskupa i dziękuję za nie. Niepodobna mi wszakże w olbrzymim chaosie zajęć, kłopotów utrzymać w pamięci każdy szczegół, choć będę się o to starał. Opóźnianie numeru jest w początkach rzeczą nieuniknioną skutkiem drukarni i niewyćwiczenia zecerów. To musi być. Tak było z „Ruchem” i jest z każdą gazetą. Na to jest jedna rada - cierpliwość. Czasem dopiero o 6 drukarnia wydaje 1-szy numer. Dziś już jest lepiej. Mnóstwo numerów kradną na pocztach. W razie przegrania procesu doda się „Przedświt Polski”. Proszę bardzo o listy do znajomych księży, gdyż mało kto z nich wie o zmianie co do „Ruchu”. Czy to nie jest szczęście i uniknienie szkandalu założenie nowego pisma?

Łączę wyrazy czci najgłębszej, oddany

Ks. Teodorowicz

52 „Przedświt” - dziennik o programie chrześcijańsko-społecznym wychodzący we Lwowie w 1. 19001904. Pierwszy numer ukazał się w grudniu 1900 r. Jako wydawca podpisywał dziennik Mieczysław Dawid Teodorowicz, redakcją kierował początkowo kanonik Kapituły ormiańskiej ks. Józef Teodorowicz. Pismo ukazywało się po południu. Do grona współpracowników należeli m.in.: prof. Włodzimierz Czerkawski i prof. Bronisław Dembiński. Od marca 1902 r. kierownictwo literackie i dział recenzji teatralnych objął Zygmunt Sarnecki, ale w styczniu 1903 r. odszedł z redakcji. W marcu t.r. zastąpił go Edmund Sas-Naganowski. W 1903 r. dziennik przeszedł na własność spółki udziałowej, deklarującej kontynuację dotychczasowej linii redakcji. M. D. Teodorowicz w imieniu konsorcjum otworzył drukarnię „Polonia”, gdzie ukazywało się pismo. W okresie 31 III - 12 IV 1903 r. E. Naganowski pełnił obowiązki redaktora naczelnego. W 37 numerze z 1903 r. Krzysztof Mieroszewski i prof. W. Czerkawski wydrukowali oświadczenie, iż pismem kieruje komitet redakcyjny. Odpowiedzialność za dziennik przejęły wyżej wymienione osoby z Krakowa. Nakład spadł z 3500 egz. do 1160 (1903 r.). „Przedświt” przestał wychodzić 31 I 1904 r. C. Lechicki, Z dziejów prasy, s. 177-182; J. Jarowiecki, Prasa lwowska, s. 318 (nieścisłości i błędy); AJWK, bsygn., M. Smoleń, „Przedświt” 1900-1904. Monografia dziennika, Kraków 2007, passim, mps (praca magisterska pisana pod kierunkiem ks. prof. dr. hab. Józefa Wołczańskiego na Wydziale Historii Kościoła Papieskiej Akademii Teologicznej w Krakowie).

b Zgodne z oryginałem - tak konsekwentnie dalej; poprawnie powinno być: skandalu.

Zgodne z oryginałem; poprawnie powinno być: myślałem.

${ }^{53}$ Właściwie: Schier Aleksander - adwokat zamieszkały we Lwowie przy ul. Kopernika 28. 


\section{Dokument 8}

Lwów, d[nia] 22/XII 1900

Najczcigodniejszy Księże Arcypasterzu! ${ }^{\mathrm{a}}$

Zawadzki spuścił na 6 tysięcy, a mnie się zdaje, że spuści na 3. Ale straszliwie durch die Rechnung ${ }^{54}$ brak posady. Dziś już mamy około 600 prenumeratorów i w ogóle pismo mimo uprzedzeń początkowych życzliwe znajduje poparcie. Można się od biedy puścić na to, żeby obok „Ruchu” wychodziło, gdyż to by pozyskało pismu mnóstwo świeckich. Np. dotąd przeważnie świeccy prenumerują. Do nowej formy muszą się z wolna dopiero przyzwyczaić. Kronika jest właściwie na każdej stronie. Czy by nie można puścić kurendy poufnej do duchowieństwa, ażeby o właściwym stanie rzeczy powiadomić? Oczywiście musiałoby to być zrobionym jak najrychlej. Jeszcze nie jest maszyna zorganizowana jak należy, ale do paru tygodni będzie w porządku. Mnie dosyć zdrowie służy, mimo szarpaniny. Listu z „Głosu Narodu” 55 nie można odszukać, zresztą „Gazeta Kościelna”"56 już przed 1-szym nie wyjdzie więcej. Czekam dyspozycji, a tymczasem składam najserdeczniejsze życzenia świąt z czcią najgłębszą i szacunku. Oddany sługa

Ks. Teodorowicz

Znam tu pewnego byłego obywatela, który gospodarzy bardzo dobrze, a stracił tylko dlatego, że wziął był dzierżawę u człowieka, którego majątek zlicytowano. Jest to przy tym człowiek pewny. Jeśliby się przydał Księdzu Arcybiskupowi mógłbym go polecić na jakiekolwiek stanowisko. Nazywa się Dobrowolski ${ }^{57}$. Co z listem do Lenkiewicza?

\section{Dokument 9}

\section{Najczcigodniejszy Księże Arcypasterzu! ${ }^{a}$}

a Powyżej obcą ręką napisano niebieską kredką nazwisko: „Teodorowicz”. List pisany jest na podwójnej kartce formatu kieszonkowego, bez znaku wodnego.

${ }^{54}$ Niem.: inaczej niż myślałem.

55 "Głos Narodu” - dziennik polityczny, społeczny i literacki założony przez Józefa Rogosza w 1893 r. Wychodził w Krakowie w l. 1893-1939. Funkcje redaktorów naczelnych i odpowiedzialnych pełnili: Józef Rogosz, Adolf Nowak, Kazimierz Ehrenberg, Ludwik Glatman, Włodzimierz Lewicki, Józef Mosch, Antoni Beaupré, Roman Woyczyński, Jan Matyasik, Konstanty Turowski. Polskie czasopisma, s. 208.

56 „Gazeta Kościelna” - tygodnik poświęcony problematyce religijno-społecznej, wydawany przez Towarzystwo Wzajemnej Pomocy Kapłanów we Lwowie w l. 1893-1939. Redakcję prowadzili: ks. Alojzy Jougan i ks. Zygmunt Lenkiewicz (1893-1898), ks. Józef Chęciński (1898-1906), ks. Maciej Sieniatycki (1906-1907), ks. Aleksander Pechnik (1907-1931), ks. Michał Rękas (1931-1935), ks. Piotr Stach (1935), ks. Józef Dajczak (1935-1937), ks. Michał Milewski (1937-1939), ks. Władysław Pilin (1939). Bibliografia katolickich czasopism religijnych $w$ Polsce 1918-1939, red. Z. Zieliński, Lublin 1981, s. 106-107.

57 Postać niezidentyfikowana.

a Powyżej obcą ręką napisano niebieską kredką nazwisko: „Teodorowicz” i rzymską cyfrę „I”. List pisany jest na podwójnej kartce formatu kieszonkowego. Kartka nie posiada znaku wodnego. 
Pisze mi właśnie ks. Sapieha donosząc o treści listu Mycielskiego ${ }^{58}$. Chciałbym atoli zwrócić uwagę Waszej Arcypasterskiej Mości na rzecz inną, o której już czasu nie miałem pomówić - oto wbrew życzeniu Księdza Arcybiskupa, ażeby spółka była związana na rok tylko, adwokat i Mycielski przedłożyli projekt, aby spółka była wieczną, to znaczy bez terminu. Postanowiono, że do zerwania spółki potrzeba jednomyślności głosów, tak samo przy przyjęciu nowego członka.

Otóż zwracam uwagę na całe niebezpieczeństwo podobnego procederu. Jeden bowiem Mycielski wystarczy, ażeby całą rzecz wedle woli swej trzymać i nią kierować więc np. - gdy po roku zechce Ksiądz Arcybiskup co z pismem zrobić, natrafia się na opór Mycielskiego, który jeden nie daje. I na to nie ma rady wówczas. Prawda, że możemy po roku trzej wystąpić, ale i to prawda, że musiałby wypłacić, a Mycielski za te pieniądze choćby sam może prowadzić pismo dalej. Tak samo przy przyjęciu nowego członka. Więc jeśli już się nie określa terminu spółki, to musi być punkt w układzie, iż tak o rozwiązaniu spółki, jak o przyjęciu nowego członka decyduje większość głosów. Od tego punktu nie można odstępować, nawet choćby Mycielski zerwał. Zresztą nie boję się o jego zerwanie. Zerwie na chwilę, a potem sam nas prosić będzie. W końcu mam wszelką nadzieję, że później ktoś się wynajdzie na miejsce jego. Co do piątego, o którym Mycielski pisze, to i owszem niech tak będzie, ale musi się wiedzieć kto on wątpię wszakże, czy tak dorywczo i na zawołanie da się ten piąty wytrzasnąć.

Tymczasem łączę wyrazy najoddańsze czci i szacunku

Stanisławów ${ }^{59}$, d[nia] 29/XII [1]900

Ks. Teodorowicz

\section{Dokument 10}

\section{Najczcigodniejszy Księże Arcypasterzu!}

${ }^{58}$ Mycielski Jerzy (1856-1928), doktorat z historii uzyskał w 1876 r. na UJ w Krakowie, w 1881 r. habilitował się tamże, 1881-1894 docent historii na UJ, w 1894 r. uzyskał rozszerzenie habilitacji na historię sztuki podejmując zarazem z tego zakresu wykłady, w 1899 r. prof. nadzwyczajny, w 1910 r. prof. zwyczajny, członek Akademii Umiejętności w Krakowie oraz stowarzyszeń zajmujących się historią i konserwacją dzieł sztuki, 1884-1914 redaktor „Przeglądu Polskiego” - czołowego organu kół konserwatywnych, 1917-1918 członek wiedeńskiej Izby Panów; w czasie I wojny światowej działał w NKN i popierał Legiony Polskie. J. K. Ostrowski, Jerzy Mycielski (1856-1928), w: Uniwersytet Jagielloński. Złota Księga Wydziału Historycznego, red. J. Dybiec, Kraków 2000, s. 108-117; A. Bochnak, Mycielski Jerzy, w: PSB, t. 22, red. zbior., Wrocław 1977, s. 332-335.

${ }^{59}$ Stanisławów - miasto w Galicji (Małopolsce) Wschodniej, po 1918 r. stolica województwa stanisławowskiego; funkcjonował tam kościół parafialny obrządku ormiańskokatolickiego, parafia rzymskokatolicka oraz stolica eparchii greckokatolickiej.

a Powyżej napisane niebieską kredką nazwisko: „Teodorowicz” i data: „1900”. List pisany jest na podwójnej, nieliniowanej kartce formatu kieszonkowego. Znak wodny przedstawia kartusz herbowy z koroną. Wewnątrz kartusza widnieje napis: „Princess Mill Ivory Paper”. 
Ksiądz Sapieha oświadczył mi dziś, iż Ksiądz Arcybiskup jednak życzy sobie zatrzymania Konecznego ${ }^{60}$. Stosuję się tedy do życzenia Waszej Arcybiskupiej Mości i piszę właśnie do Konecznego. Wobec tego jednak, że ciągle mnie ostrzegają, by na piśmie go związać (jezuici dali mu redagowanie "Grzmotu”61 i musieli mu podziękować, etc., etc.) więc zbieram w jedno całą moją ustną z nim umowę i przedkładam na piśmie jemu warunki raz już umówione pośród których za niezbędny uważam ten, aby on podpisywał pismo, od czego jak uważam, chce się zręcznie wykręcić. Piszę o tym wszystkim Księdzu Arcybiskupowi, by On przypadkiem rzeczy inaczej nie przedstawiał.

Ksiądz Arcybiskup doradzał mi także, bym mu wytknął błędy. Tego jednak uczynić nie mogę a to $\mathrm{z}$ tego powodu, że uważam to za rzecz, która go podrażni tylko, ale nic nie pomoże. Te wszystkie błędy płyną bowiem u niego z istotnego defektu, którym jest kompletny brak zmysłu redagowania i politycznego, do tego jeszcze jest i to źródło, że nie jest konserwatystą krakowskim. Na to nic nie pomoże zwracać uwagę, tak jak nic nie pomoże mówić ślepemu, że coś przeoczył. W jednym tylko tygodniu on narobił hecę $\mathrm{z}$ „Kalendarzem”62 , który jest jednym z najlepiej wydawanych, poróżnił nas z jezuitami, którzy do tego „Kalendarza” piszą, odstręczył jedynego prawie katolickiego posła Kozłowskiego ${ }^{63}$ (o tym mu mówiłem, ale on spojrzał na mnie jak na ignoranta i nawet nic nie odpowiedział i napisał parę innych artykułów, z których jeden mam u siebie niemożliwy do drukowania). Kto tak dokumentnie wykazał swój kompletny brak zmysłu w rzeczach praktycznych i politycznych, kto przy tym ma wiarę pełną w swoje słowa, kto moją uwagę jak o Kozłowskim przyjmuje z uśmiechem politowania, do tego jest pisać rzeczą straszną. Daruje więc Ksiądz Arcypasterz, ale ja pisać do niego nie będę, jak tylko w urzędowej sprawie to jest formułując punkta ${ }^{\text {b }}$ ugody, spełniając życzenie Waszej

${ }^{60}$ Koneczny Feliks (1862-1949), dr filozofii, 1890-1897 pomocnik kancelaryjny i adiunkt Akademii Umiejętności w Krakowie, 1897-1919 pracownik Biblioteki Jagiellońskiej, habilitacja w 1920 r. na UJ z dziejów Europy Wschodniej, 1920 r. prof. nadzwyczajny, 1922 r. prof. zwyczajny, 1919-1929 kierownik Katedry Historii Europy Wschodniej na Uniwersytecie Stefana Batorego w Wilnie. Od 1929 r. przebywał na emeryturze w Krakowie; 1905-1914 redagował „Świat Słowiański”, 1896-1905 recenzent teatralny „Przeglądu Polskiego”. Publikował na łamach „Muzeum”, „Przeglądu Powszechnego”, „Świata”, „Tęczy”, „Tygodnika Warszawskiego”, "Głosu Narodu". Był autorem wielu rozpraw z historii Europy, Polski, kultury narodowej. J. Mitkowski, Koneczny Feliks Karol, w: PSB, t. 13, red. zbior., Wrocław-Warszawa-Kraków 1967, s. 498-499.

61 "Grzmot” - pismo założone przez o. Jana Badeniego SJ; było organem stowarzyszeń katolickich robotników, ukazywało się w l. 1896-1898 najpierw we Lwowie, potem w Krakowie. Początkowo wychodziło trzy razy tygodniowo, później raz w tygodniu. Na jego łamach poruszano problematykę społeczno-religijną. Nakład: 2000 egz. W 1898 r. zostało organem Stronnictwa Katolicko-Narodowego, a od 1899 r. wychodziło pod tytułem „Jedność”. „Grzmot”, w: EWJ, oprac. L. Grzebień, Kraków 1996, s. 201.

${ }^{62}$ Tytuł niezidentyfikowany.

${ }^{63}$ Kozłowski Włodzimierz (1858-1917), dr praw, właściciel dóbr Zabłotce Kozłowskie w pow. przemyskim, 1889-1914 poseł do Sejmu Galicyjskiego; na jego forum zajmował się zagadnieniami budżetowymi, gospodarstwa krajowego, szkolnictwa, 1885, 1902, 1905-1917 poseł do parlamentu wiedeńskiego; w sejmie był przywódcą konserwatywnego klubu „Centrum” opowiadającego się za walką z Ukraińcami oraz sojuszem z endecją, 1889-1902, 1905-1917 poseł do Rady Państwa; w Kole Polskim przewodził grupie Podolaków, należał do grona polityków konserwatywnych. J. Zdrada, Kozłowski Włodzimierz, w: PSB, t. 15, red. zbior., Wrocław-Warszawa-Kraków 1970, s. 39-40.

b Zgodne z oryginałem - tak konsekwentnie dalej; poprawnie powinno być: punkty. 
Arcypasterskiej Mości. Co do Czerkawskiego ${ }^{64}$, to całkiem słusznie zauważył Ksiądz Arcypasterz, że nie miałaby racji konferencja z nim co do udziału jego w piśmie, ja zresztą sam bym tę rzecz załatwił i ułożył z nim, chciałem atoli, by Ksiądz Arcypasterz wysłuchał ogólne jego uwagi o dziennikarstwie, gdyż uważam go za człowieka najlepiej znającego się na dziennikarstwie z tych, których kiedyś poznałem. Da się jednak na to poradzić w ten sposób, że oddam Księdzu Arcypasterzowi projekt napisany całej organizacji „Przedświtu”.

Tymczasem przepraszając za mą bazgraninę, łączę najserdeczniejsze i najoddańsze wyrazy

Lwów, d[nia] 31/XII [1]900

Ks. Teodorowicz

\section{Dokument 11}

\section{Ekscelencjo! ${ }^{\mathrm{a}}$}

W tej chwili przybyłem do domu i właśnie oddano mi list Waszej Ekscelencji i zaproszenie na dzień jutrzejszy - otóż mogę tylko oświadczyć, że milo mi będzie zadość uczynić łaskawemu wezwaniu, jawię się przeto jutro o naznaczonej porze. Przy tej sposobności łączę wyrazy prawdziwie oddane czci i szacunku

Lwów, 30/I [1]901

Ks. J[ózef] Teodorowicz

\section{Dokument 12}

\section{Najczcigodniejszy Księże Arcypasterzu!}

Nie potrzebuję chyba powtarzać jak się cieszę i raduję szczególniej tymi życzeniami, jakie otrzymałem od Waszej Arcypasterskiej Mości. Są one prawdziwie dla mnie zakładem tego zobopólnego ${ }^{\mathrm{b}}$ pożycia i tej jedności, której rezultatem będzie jednolitość myśli i jednolitość działania pomimo odmiany i różnicy w zakresach i rodzajach działalności. Jeszcze raz z głębi serca wołam - dziękuję!

${ }^{64}$ Czerkawski Włodzimierz (1868-1913), dr praw, ekonomista i statystyk; habilitacja w $1893 \mathrm{r}$. na UJ, w 1897 r. prof. nadzwyczajny ekonomii politycznej, w 1906 r. prof. zwyczajny; był jednym z założycieli Szkoły Nauk Politycznych w Krakowie; uchodzi za twórcę krakowskiej szkoły ekonomicznej, popularyzatora idei katolicyzmu społecznego i współtwórcę polskiego ruchu chrześcijańsko-społecznego. Napisał m.in.: Zasady ekonomii społecznej (1900), Zasady ekonomii politycznej (1929), Polityka ekonomiczna (t. 1-2, 1905). A. Krzyżanowski, Czerkawski Włodzimierz, w: PSB, t. 4, red. zbior., Kraków 1938, s. 335-336.

a Powyżej pisane niebieską kredką nazwisko; „Teodorowicz”. List sporządzony jest na podwójnie złożonej, nieliniowanej kartce formatu kieszonkowego. Znak wodny przedstawia kartusz herbowy z koroną. W kartuszu umieszczono napis: „Princess Mill Ivory Paper”.

a Powyżej napisano ołówkiem rzymską cyfrę ,I”. List pisany jest na podwójnej, nieliniowanej kartce formatu kieszonkowego z fragmentarycznym, nieczytelnym znakiem wodnym w lewym górnym rogu kartki.

b Zgodne z oryginałem; tu w znaczeniu: wzajemnego. 
Już dwa tygodnie dobiega jak tu jestem nad morzem. Trafiłem na dobry czas, a to tyle znaczy, co wygrałem dobry los. Ostatki jesieni są jak ostatki życia u starego, przyjdzie jedno, drugie zaziębienie i już po życiu, tak i tu przyjdzie jedna, druga [...] $]^{c}$ lub sirocco ${ }^{65} \mathrm{i}$ wszystko skończone. Ale na szczęście dotąd jest dobrze. Muszę wyzyskać czas ten jak tylko się da długo, bo mi sił wiele potrzeba. Nie robię dużo, choć ciągiem zajęty, bo pisanina mię całkiem pożera. Kąpię się co dzień w morzu, łażę po werandzie, trochę się gapię, trochę o tym i owym przemyśliwam i tak dzień steram po dniu. Myślę notabene i o "Przedświcie”, który obecnie jest w prowizorycznym stanie, ale mam nadzieję, że się świetnie rozwinie. Organizuję powoli do pisma siły piszące w Krakowie i Lwowie, tak by było złożone wszystko jeszcze przed moją konsekracją ${ }^{66}$. Nie wiem, kiedy konsystorz papieski i czy mię zamianują przez brewe czy też przez konsystorz? Polonii tu taka jest masa, że mam złudzenie, żem gdzieś w polskim mieście. Był tu parę dni Piętak, bawi brat ${ }^{67}$ Pinińskiego, pani $[. . .]^{\mathrm{d}}$, która mnie tu zaprosiła do siebie na kolację, zapewne się gniewa za to, że odmówiłem, także willę ma pani Jordanowa ${ }^{68}$, która nawiasem mówiąc urządziła obiad na cześć moją, na który jako wierny uczeń Księdza Wałęgi nie poszedłem. Tyle o mnie; jak widzi Wasza Arcypasterska Mość aż za wiele się rozpisuję i czasu drogiego zabieram; a może i ślinkę trochę Wasza Arcypasterska Mość połyka na myśl o ślicznej jesieni nad Adriatykiem?

Bardzo serdeczny, choć terminatorski list miałem od Księdza B[iskupa] Wałęgi, poczciwy od Ks. B[iskupa] Pelczara ${ }^{69}$ i Fiszera ${ }^{70}$.

Na końcu jedna prośba, co do której jestem pewny prawie, że mi Ksiądz Arcypasterz odmówi. Ale stawiam ją dlatego, by ludzie, którzy mnie o to prosili mieli to przynajmniej,

c Tekst nieczytelny.

${ }^{65}$ Wł.: sirocco - ciepły lub gorący wiatr południowo-wschodni w basenie Morza Śródziemnego wiejący znad Afryki lub Półwyspu Arabskiego.

${ }^{66}$ Konsekracja ks. Józefa Teodorowicza na arcybiskupa lwowskiego obrządku ormiańskokatolickiego miała miejsce 2 II 1902 r. we Lwowie.

67 Piniński Aleksander (1864-1902), hrabia, właściciel ziemski w Galicji, żonaty z Ireną Wolańską (18711929); brat prof. Leona Pinińskiego.

d Tekst nieczytelny.

${ }^{68}$ Postać niezidentyfikowana.

69 Pelczar Józef Sebastian (1842-1924), święcenia kapłańskie w 1864 r. w Przemyślu, dr teologii, dr prawa kanonicznego, 1864-1865 wikariusz w Samborze, 1868-1869 wikariusz w Wojutyczach i ponownie w Samborze, w roku akad. 1869/70 prefekt Seminarium Duchownego w Przemyślu, 1870-1877 wykładowca teologii pastoralnej i prawa kanonicznego w Instytucie Teologicznym tamże, 1877-1880 prof. historii Kościoła i prawa kanonicznego na Wydziale Teologicznym UJ w Krakowie, 1880-1899 prof. teologii pastoralnej tamże, w roku akad. 1881/82 i 1885/86 dziekan, 1880/81 prorektor i 1882/83 rektor UJ, od 1880 r. kanonik Kapituły Katedralnej w Krakowie; 1899-1900 biskup pomocniczy przemyski, 1900-1924 biskup diecezjalny tamże. Beatyfikowany 2 VI 1991 r. w Rzeszowie, 18 V 2003 r. odbyła się jego kanonizacja w Rzymie. H. E. Wyczawski, Pelczar Józef Sebastian, w: SPTK, t. 3, red. H. E. Wyczawski. Warszawa 1982, s. 335-346; Święty Józef Sebastian Pelczar (1842-1924). Rektor Uniwersytetu Jagiellońskiego i biskup przemyski, red. A. Kubiś, J. Wołczański, Kraków 2005, passim; informacje własne autora.

${ }^{70}$ Właściwie: Fischer Karol Józef (1847-1931), święcenia kapłańskie w 1869 r. w Przemyślu, wikariusz w Sanoku, Drohobyczu i Jaśle, proboszcz w Tarnowcu i Dobrzechowie, kanonik Kapituły Katedralnej w Przemyślu, poseł do parlamentu wiedeńskiego, 1901-1931 biskup pomocniczy przemyski. P. Nitecki, Biskupi, s. 59. 
że się wstawiałem. Zresztą Ksiądz Arcybiskup będzie sam o to proszony. Oto chodzi o niejakiego Dobrowolskiego, którego znam jako bardzo uczciwego człowieka i pracowitego, a który na dzierżawie stracił nie ze swojej winy i dziś bez miejsca w opłakanym znajduje się stanie. Otóż chciałby on się dostać na wakujące miejsce zarządcy u Dominikanów. Otóż będę u Księdza Arcypasterza z prośbą o poparcie w tej sprawie. Niestety z góry wiem, że Dominikanie swoimi znajomymi obsadzają, ale moją tu misję na tym zamykam, acz wszystko to, co o uczciwości p[ana| Dobrowolskiego powiedzą i pracowitości jest szczerą prawdą. Resztę niech Ksiądz Arcypasterz sam zarządzi jak to za potrzebne uzna.

Najserdeczniejsze łączę wyrazy z czcią najgłębszą, oddany w Chr[ystusie] sługa Ks. Teodorowicz

Abbacja $^{71}$, d[nia] 8/X [1]901

Jest tu obecnie Przygodzki ${ }^{72}$ ze Lwowa, przybył niedawno.

\section{Dokument 13}

\section{Najczcigodniejszy Księże Arcypasterzu! ${ }^{\text {a }}$}

Przede wszystkim składam gratulację najserdeczniejszą listu pasterskiego ${ }^{73}$. Jakkolwiek jestem sceptykiem na punkcie praktycznego skutku w tej sprawie, to jednak co do listu samego uderzony jestem istnym mistrzostwem w pogodzeniu tego prostego, popularnego tonu zrozumiałego i dla prostaczka, z rozumem i logiką, i tej praktyczności wywodu ze sercem, a raczej tę mowę serca ciągle na oku mającą słuchacza. Szczególniej ponad wszystko wybija się ta niewymuszona, a taka popularna prostota.

A teraz do interesów. Otóż Księże Arcypasterzu narażony jestem na okropne przykrości i kolizje wskutek tego, że obiecane mi na 1-szy, potem połowę listopada pieniądze dotąd wypłaconymi nie zostały prócz 2 tysięcy. Obiecałem licząc na pewne na to, że Ksiądz Arcypasterz da część przypadającą w nuncjaturze ${ }^{74}$ przed paru tygodniami wypłacić. Nuncjusz urguje, jako na niedotrzymującego słowa. Zaciągnąłem i inną pożyczkę tymczasowo. Wreszcie „Przedświt” od 1-szego jest niewypłacalnym i pismo w tej właśnie chwili traci w opinii, w której najbardziej jej potrzebuje. Nie tracę więcej słów i proszę tylko o bezzwłoczne wydostanie pieniędzy i oddanie przez Księdza Sapiehę.

${ }^{71}$ Abbacja - bardzo znana miejscowość letniskowa w Istrii nad Adriatykiem, dziś: Opatija w Chorwacji.

72 Przygodzki Janusz - dr praw, urzędnik Wydziału Krajowego we Lwowie, wiceprezes Stronnictwa Katolicko- Narodowego we Lwowie, członek Chrześcijańskiej Demokracji Małopolski Wschodniej, członek Rady Miejskiej Lwowa i Komitetu Związku Katolicko-Społecznego archidiec. lwowskiej, aktywny działacz ruchu chrześcijańsko-społecznego Galicji (Małopolski) Wschodniej. J. Wołczański, Ksiadz Szczepan Szydelski, passim.

a Powyżej obcą ręką napisano niebieską kredką nazwisko: „Teodorowicz”. List pisany jest na trzech podwójnych, nieliniowanych, numerowanych kartkach formatu kieszonkowego. Kartki posiadają znak wodny z napisem: „Vienna Manufacture. Original Margaret Mill” oraz emblemat przedstawiający trzy kwiaty.

${ }^{73}$ Zob.: J. Bilczewski, W sprawie nauczania katechizmu. List pasterski do wiernych archidiecezji. Lwów 20 stycznia 1901 r., w: tenże, Listy pasterskie i mowy okolicznościowe, Mikołów-Warszawa 1908, s. 43-66.

${ }^{74}$ Kościół katolicki w Galicji podlegał nuncjaturze apostolskiej w Wiedniu. 
W sprawie pisma, które ostatecznie musi uregulować, chcę mieć osobną konferencję z Księdzem Arcybiskupem. Na razie tyle donoszę z faktów i planów.

Obecnie sporządza się najszczegółowszy rachunek z 1-szego roku wydawnictwa. Osobny człowiek bardzo fachowy pracuje nad tym od kilku dni i w ciągu tego miesiąca dostanie takowy Ksiądz Arcypasterz do rąk. Drugi rachunek przeciętnych dochodów i rozchodów dostanie Ksiądz Arcybiskup wcześniej jeszcze.

Na przyszłość chciałbym, by Ksiądz Arcybiskup miał swego stałego kontrolera czy kasjera w piśmie tak, by za stronę materialną pisma ani ja, ani mój brat odpowiedzialnym nie był. Gdyby Ksiądz Sapieha lub Ksiądz Zajchowski ${ }^{75}$ chcieli się podjąć tego byłoby bardzo dobrze.

Teraz co do redakcji. Otóż zamówiłem Konecznego z Krakowa mimo kolosalnej ceny jakiej on żąda, uważałem bowiem, że Ksiądz Arcybiskup nie ma zaufania do mego brata. Dziś jednak, gdy na Konecznym ma zostać tyle powiem, że brat mój okazał ogromny talent dziennikarski, że w tym krótkim czasie dziennikowi umiał nadać typ i formę odrębną od innych, że zespolił różne talenta ${ }^{\mathrm{b}}$ przy piśmie. Dziś więc niech mi to wolno będzie powiedzieć, gdy nie mogę być podejrzanym już o nic. Niestety, Przygodzki podkłada mu stołki chcąc mieć Madurowicza, który jest wprost niemożliwym. Zostaje więc Koneczny. O nim osobno pomówię z Księdzem Arcypasterzem.

Teraz co do bilansu pisma. Otóż z książek przedłożonych dowie się Ksiądz Arcybiskup, że prenumerata stale rośnie. To dowód najlepszy rozwoju i racji bytu pisma. Grzechem pierworodnym „Przedświtu” był ten, że nie miał kapitału zakładowego. Pierwszy rok pisma kosztuje zawsze 30 tysięcy. Tyle kosztował "Głos Narodu” (ma 40 tysięcy długu), tyle „Nowa Reforma”76, mniej więcej tyle wpakowano w „Ruch Katolicki”. „Przedświt" stosunkowo wyszedł obronną ręką wydając około 20 tysięcy. Otóż przyszłość pisma przedstawia się najświetniej. Subwencja 12 tysięcy rocznie wystarcza do najlepszego prowadzenia pisma już przy dzisiejszej liczbie prenumeratorów. A jest nadzieja na więcej, siły już dziś stają przy gazecie bardzo poważne. Organizacja społeczna stąd się rozpocznie. Jedno tylko musi się nasztukować, to jest pierwszy rok. To się da zrobić przez pożyczkę 30 tysięcy umarzaną ratami (tysiąc pięćset rocznie rata). To jedno od

75 Zajchowski Józef (1861-1939), święcenia kapłańskie w 1883 r. w Przemyślu, dr prawa kanonicznego, 1883-1887 wikariusz w Jaworowie, od 1887 r. kanclerz Konsystorza Biskupiego Przemyskiego, w 1888 r. sędzia w Sądzie Biskupim tamże, 1889-1901 wykładowca historii Kościoła i prawa kanonicznego w Instytucie Teologicznym w Przemyślu oraz prefekt Seminarium Duchownego tamże, od 1901 r. na zaproszenie abp. J. Bilczewskiego objąłkanonię w Kapitule Metropolitalnej we Lwowie. Był członkiem Stronnictwa Narodowo-Demokratycznego we Lwowie, należał do Rady Nadzorczej Kasy Oszczędności i Kredytu we Lwowie, angażował się w ruchu chrześcijańsko-społecznym, wchodził w skład Kresowego Biskupiego Komitetu Ratunkowego (KBK) we Lwowie. W 1925 r. został szefem komisji delegatów kurii biskupich prowincji kościelnych lwowskiej i krakowskiej powołanej w celu przygotowania materiałów na obrady biskupów w maju t. r. na temat konkordatu. W 1928 r. reprezentował abp. Bolesława Twardowskiego w pracach mieszanej komisji kościelno-rządowej w sprawie ustaw uchylonych przez konkordat. Cieszył się wielkim zaufaniem i autorytetem w kościelnym środowisku lwowskim. J. Wołczański, Listy biskupa, s. 309.

b Zgodne z oryginałem; poprawnie powinno być: talenty.

${ }^{76}$ „Nowa Reforma” - dziennik wychodzący w Krakowie w 1. 1882-1928. Funkcje redaktorów pełnili: Adam Asnyk, Michał Konopiński, Tadeusz Romanowicz, Tadeusz Rutowski, Bolesław Lutostański, Mieczysław Pawlikowski, Konstanty Srokowski. Polskie czasopisma, s. 426-428. 
razu stawia pismo na nogi i daje mu trwałą podstawę. Ksiądz Arcybiskup mi mówił, że Mycielski chciałby podpisać. Ja bym wolał, by mógł tę pożyczkę wyrobić Ksiądz Arcybiskup, bo by wtedy nikt obcy w piśmie nie gmyrał. Raty zaś roczne potrącałby Ksiądz Arcybiskup ze subwencji, a i tak podobną pożyczkę chciał Ksiądz Arcybiskup zaciągnąć na Dom Katolicki ${ }^{77}$. Tym jednym aktem raz na zawsze stawia się pismo. Mogłyby dodatkowo być rozważone udziały, ale i na ten sposób potrzebna jest teraz pożyczka, bo udziały to rzecz powolna. Ostatnim refugium ${ }^{78}$ moim zdaniem dla pisma zabójczym jest zlanie z innym pismem. Wtedy finansowo się wychodzi, ale duchowo się traci. „Przedświt” idący dziś swoją niezależnością tak potrzebną zwłaszcza wobec kulturkampfu ${ }^{79}$ idącego na nas, „Przedświt” wlewający nowe tętno staje się kaiserköniglichkeit ${ }^{80}$. To cios śmierci, to znaczy tyle, co całą ideę pisma zabić i to wtedy, gdy ono najlepsze rokuje nadzieje.

Co do kierunku pisma byłoby najlepiej gdybyśmy we dwu pismem kierowali mając cotygodniowe narady. Komitet rzeczą jest dobrą byle z głosem doradczym. Poddaję te rzeczy w pośpiechu na papier rzucone Księdzu Arcybiskupowi, proszę rozważyć, a pojutrze ja przybędę lub najdalej za dwa dni. Tymczasem proszę o pieniądze zaraz, bo ludzie niepopłaceni, a ja wyczerpany i zaangażowany. Najserdeczniejsze łączę wyrazy czci i hołdu.

\section{Oddany}

Putiatyńce $^{81}$, dnia 3/XI [1]901

Ks. Teodorowicz

Dołączam list brata pisany do mnie do Abbacji. Wtajemniczy on lepiej jak moje rozprawy Księdza Arcypasterza i w maszynę „Przedświtu”, a da poznać jak brat się orientuje wyśmienicie w każdej kwestii redakcyjnej i jak gotów zrobić wszystko, co mu się poleci.

\section{Dokument 14}

\section{Najczcigodniejszy Księże Arcypasterzu!}

Chciałem koniecznie osobiście przybyć, ale tak jestem całą sprawą i fizycznie, i duchowo przybity, że dla osłabienia ruszyć się z domu nie mogę.

77 Dom Katolicki - instytucja powołana do życia przez abp. J. Bilczewskiego we Lwowie dla stowarzyszeń katolicko-społecznych. Gmach został wzniesiony przy ul. Gródeckiej, a jego otwarcia i poświęcenia dokonał wspomniany hierarcha 29 I 1911 r. M. Tarnawski, Arcybiskup, s. 164-165.

78 Łac.: ucieczka.

${ }^{79}$ Niem.: walka o kulturę. Nawiązanie do walki rządu pruskiego z Kościołem katolickim w 1. 1871-1878 w celu wyeliminowania jego wpływów w Niemczech.

${ }^{80}$ Niem.: lojalny względem monarchii austro-węgierskiej.

${ }^{81}$ Putiatyńce - wieś w pow. Rohatyn, woj. Stanisławów.

a List pisany na 9,5 stronicach czystego papieru formatu kieszonkowego. W lewym górnym rogu strony tytułowej napisane obcą ręką niebieską kredką: „Teodorowicz IV”. Brak miejsca wystawienia dokumentu i datacji. Papier posiada znak wodny przedstawiający napis: „Star Mill Hand-Made” oraz sześcioramienną gwiazdę z umieszczoną wewnątrz datą: „1866”. 
Bardzo a bardzo żałuję i przepraszam, żem mimo woli Księdzu Arcypasterzowi sprawił taką przykrość. Ale świadczę się Bogiem, że najlepiej myślałem o tym człowieku i dopiero po próbie przekonałem się, że zupełnie się nie nadaje na redaktora. Bez próby nigdy o nikim nie można powiedzieć, czy ma talent redaktorski. Tak jak ktoś może być teoretycznie kaznodzieją, ale skoro prawd nie umie aplikować ad captum ${ }^{82}$ słuchacza, albo gdy nie ma taktu w napominaniu, albo gdy nie zna audytorium, to choćby był nie wiem jak kuty w dogmatyce, do niczego się nada a słuchacza odstręczy; a na odwrót może być ignorant, ale gdy czuje ze słuchaczem, wie co mu się w danej chwili podoba, co go poruszy, to choćby tę ignorancję swoją poparł podręcznikami obcymi, ma jednak zmysł kaznodziejski, podobnie się ma z redaktorstwem. Praktyka może dopiero nauczyć. Do tego podowiadywałem się o Konecznym teraz dopiero różnych rzeczy. Więc ja zawiedzionym zostałem tak, jak Ksiądz Arcybiskup, w dodatku Mycielski przypuścił go od razu przy Księdzu Arcybiskupie do najtajniejszych rzeczy.

Jeszcze jedna okoliczność. Przy Konecznym koniecznym jest Kuśmiński ${ }^{83}$. Bez Konecznego on odpada także, lecz Konecznego koszta redakcji o przeszło 3 tysiące rocznie się zmniejszają, to jest w 3 latach około 10 tysięcy. Czyli, że ubytek Konecznego to równa się przybyciu jednego udziałowca. Mam cały plan organizacji redakcji. Zresztą już w tej chwili nie piszę, ale go przedłożę Waszej Arcybiskupiej Mości. Przybędę po obiedzie lub jutro około 5-tej. Tym razem łączę najoddańsze wyrazy przepraszając raz jeszcze za mimo woli sprawioną przykrość, którą doskonale pojmuję i rozumiem.

Najoddańszy

Ks. Teodorowicz

Właśnie przybywa Ks. Sapieha. Co do sprawy Ks. Sapiehy pomówimy osobno. Tylko co do punktów poruszonych odpowiadam.

A) Że Koneczny zobowiązał się podpisywać dziennik, to zresztą uważałem w umowie za kardynalny punkt, dla siebie, bo na nim ciąży odpowiedzialność za pismo, a nie na mnie. Jeszcze ostatnim razem mi mówił, że tymczasowo będzie się podpisywał jako kierownik działu felietonowego by oswoić opinię, a potem gdy przyjedzie - całą redakcję. I teraz w liście do mnie mówi tylko o projekcie tymczasowego przez kogo innego. Zaraz jednak istne miałem podejrzenie co do tego, że się chce wykręcić. To, że Ksiądz Arcybiskup mówił wprost, że nie będzie podpisywał, jest bardzo jak na niego niemożliwym. Wszakże podobnie zrobił w innej sprawie. Z Mycielskim się umówił w Krakowie, że bezpłatnie przybędzie na grudzień do Lwowa. Ja nic nie wiedząc o tym przybywam do Krakowa, a on nie wspominając o umowie z Mycielskim, każe sobie zapłacić 100 reńskich jako jego koszta pobytu we Lwowie. Dziś mi właśnie ten pasztet przysłał do zapłacenia.

B) Redakcję on objął zaraz, a brat ustąpił mu wszystko jako kierownikowi. Swoją droga głównie pilnował wizyt i prawie nic tu nie robił. Ja go raz spotykam, a on mi mówi: jeszcze śniadania nie jadłem (o 11-tej rano!) tyle wizyt musiałem robić. A przecie sobie kazał za to tak suto płacić!

82 Łac : dla pozyskania.

${ }^{83}$ Postać niezidentyfikowana. 
C) Jezuici mi dopiero donieśli o "Grzmocie”, tak samo inne rewelacje przyszły ex post ${ }^{84}$.

Zdaje się już jutro będę u Księdza Arcypasterza z całym gotowym planem. Dodaję i to, że ten człowiek mógłby tak łatwo intrygować między nami, skoro już dziś tą wartością tak trudne stwarza sytuacje.

\section{Dokument 15}

Najczcigodniejszy Księże Arcypasterzu! ${ }^{\mathrm{a}}$

W odpowiedzi na punkta podniesione w liście Księdza Sapiehy tyle tylko zauważyć mogę:

1) że co do mnie mam tylko wątpliwość czy on podpisywać umie, ale nie mam pewności;

2) że Koneczny się ze mną umówił o podpis, a umowę ze mną uważam tak ja, jak on za istotną. Więc Ksiądz Arcypasterz w niczym nie jest wobec niego zobowiązany. Ja mu zresztą osobiście zaręczyłem te 2400 f[lorenów], więc z natury rzecz wynika, że tylko do mnie może mieć pretensję, a i tylko na mnie odium spada.

Jeżeli piszę do niego o podpis to powołuję się na to, jako na istotny warunek naszej umowy, gdyż właśnie mi głównie przecie chodziło o to, by siebie zasłonić jego nazwiskiem równocześnie pomagając pismu. Zresztą Koneczny pisał teraz do mnie projektując, by „tymczasem” pismo „Madurowicz” podpisywał, więc tym słówkiem daje najwyraźniej poznać, że on podpisać myśli. Wątpliwości co do podpisu nasuwa mi jego przełożony w bibliotece p[an] Semkowicz ${ }^{85}$, który ogromnie niechętnie przyjął Konecznego jako mającego famę niezdarnego robotnika i przez Smolenia ${ }^{86}$ przekazywał do redakcji, że będzie robił trudności w tej sprawie. O tym także dowiedziałem się dopiero post factum $^{87}$. Nie mogłem zaś przypuścić nawet, by „Przedświt” był bez podpisu Konecznego przedtem, gdyż pismo osiadłoby bez podpisu na lodzie. Bo ani mój brat, ani Madurowicz z chwilą objęcia przez kogoś innego nie będą kłaść swój podpis i brać odpowiedzialność za kogoś innego. Więc co się z pismem stanie?

Nie mam nic przeciw temu, by były poruszone te punkta, ale one tylko dowodzą jednego, to jest, że przyjęcie Konecznego jest zabiciem „Przedświtu”, ale nie osiąga się tymi argumentami wobec Konecznego nic, bo on najspokojniej powie, że wedle jego zdania

${ }^{84}$ Lac.: po fakcie.

a Powyżej obcą ręką napisano niebieską kredką nazwisko: „Teodorowicz” i czerwoną kredką rzymską cyfrę: „VI”. Brak miejsca wystawienia dokumentu, autografu autora i datacji. List pisany jest na podwójnej, nieliniowanej kartce formatu kieszonkowego bez znaku wodnego.

${ }^{85}$ Semkowicz Aleksander (1850-1923), dr filozofii, od 1876 r. bibliotekarz Biblioteki Uniwersyteckiej we Lwowie, od 1892 r. dyrektor tejże, habilitował się w 1884 r. na Uniwersytecie Lwowskim w zakresie historii powszechnej, w 1889 r. prof. nadzwyczajny; w 1886 r. był współzałożycielem Towarzystwa Historycznego we Lwowie, redagował też „Kwartalnik Historyczny”. W. Bieńkowski, Semkowicz Aleksander, w: PSB, t. 36, red. zbior., Warszawa-Kraków 1995-1996. s. 231-232.

${ }^{86}$ Postać niezidentyfikowana.

87 Łac.: po fakcie. 
wszystko było bez zarzutu. Poruszanie zresztą punktów niełamiących umowy może nastąpić każdej chwili, ale ważniejsza rzecz jest upomnieć się najpierw o rzecz istotną. Tak przynajmniej mnie się zdaje. Załączam zresztą tu list mój do Konecznego, który lepiej rzecz zilustruje. Raz jeszcze powtarzam, że przed zawiązaniem spółki, przed oddaniem Konecznego przeze mnie spółce, tylko ja z nim na mocy umowy mogę traktować, więc Ksiądz Arcybiskup wolny jest od wszelkiej wobec niego odpowiedzialności.

Łączę wyrazy najoddańsze i najgłębsze ${ }^{\mathrm{b}}$

\section{Dokument 16}

Najczcigodniejszy Księże Arcypasterzu! ${ }^{\mathrm{a}}$

Sobota

Od przedwczoraj jestem chory. Wczoraj leżałem w łóżku, ale nie odpowiadałem, dlatego iż myślałem, że dziś będzie całkiem dobrze. Mam się wprawdzie dziś lepiej, ale chodzę już w pokoju, lecz zawsze potrzeba mi się zaszanowaćb i starannie unikać wszystkiego, co by wywołać mogło jakie silne wzruszenie. Wobec tego muszę prosić Księdza Arcypasterza o zwolnienie mnie od dzisiejszego zaproszenia i usprawiedliwienie. Nadmienić przy tym muszę, że z Panem Pilatem ${ }^{88}$ zerwałem stosunki, więc widzenie się nasze może być naraz niemiłe i Księdzu Arcybiskupowi, i mnie, i jemu. O powodach tych chciałem właśnie ustnie pomówić z Księdzem Arcybiskupem, ale że się trzymam zasady, by jak najmniej czasu zabierać Waszej Arcypasterskiej Mości, więc odkładałem widzenie się, aż spółka odjedzie i coś z „Ruchem” załatwi, by tak skumulować kwestie, a nie traktować odmiennie. Z P [anem] Pilatem była sprawa tego rodzaju.

Objąwszy „Przedświt” rozumiałem, co czynię. Nie tyle pracą, ale dawałem me nazwisko. Dziś nikt nikogo z[a] gazetę nie czyni odpowiedzialnym tylko mnie. Jest to faktem. Choćby wiedziano, że Ksiądz Arcypasterz daje pieniądze, to jednak mimo wszystko mnie czynią i czynić będą odpowiedzialnym przed społeczeństwem. Jeśli nikt w świecie nie może się domagać ode mnie ażebym kładł nazwisko na książkę, gdzie w brew mej intencji powkładał ktoś ustępy, to a priori ${ }^{89}$ ma się to rozumieć o dzienniku. Raczej mogę ustąpić, aniżeli dozwolić na wściubianie się obu i niepowołane w kierunek dziennika,

b Brak autografu autora.

a List pisany na 6 stronicach czystego papieru formatu kieszonkowego ze znakiem wodnym: „Victoria Note Paper". Brak miejsca wystawienia dokumentu i datacji.

b Zgodne z oryginałem; w znaczeniu: oszczędzać.

${ }^{88}$ Pilat Tadeusz (1844-1923), dr praw, 1867-1872 urzędnik Namiestnictwa we Lwowie, w 1868 r. habilitacja na Uniwersytecie Lwowskim z ekonomii społecznej, w 1872 r. prof. nadzwyczajny austriackiego prawa administracyjnego, nauki administracji i statystyki Uniwersytetu Lwowskiego, w 1878 r. prof. zwyczajny, w roku akad. 1886/87 rektor, 1887/88 prorektor, wielokrotny dziekan Wydziału Prawa, w 1902 r. przeszedł na emeryturę, ale nadal wykładał jako prof. honorowy do 1923 r. Był pionierem naukowych badań statystycznych w Galicji, 1876-1914 poseł na Sejm Galicyjski, 1901-1920 członek Wydziału Krajowego i zastępca marszałka krajowego. J. Zdrada, Pilat Tadeusz,w: PSB, t. 26, red. zbior., Wrocław 1981, s. 237-239.

${ }^{89}$ Łac.: z góry. 
który jest dzieckiem mym duchownym i którego obraz duchowy i kierunek ja wykołysałem w duszy.

Otóż osobista wolność jest warunkiem, od którego nie mogę odstąpić, a samo żądanie ograniczenia $[\ldots]^{c}$ tej wolności, musiałbym uważać za krzywdzące najcięższe postępowanie ze mną zwłaszcza po ofierze jako wbrew wszelkim moim duchowym, moralnym, ba nawet materialnym interesem służyłem. (Nie dano mi teraz urzędu proboszcza niosącego grubą resztę, dlatego, że „Przedświt” prowadzę). Ale nie tylko dla mej osoby. Dla dobra dziennika niezależność kierującego jest pierwszym warunkiem. Gdy ktoś raz, ten raz ów zaczyna w dzienniku zaznaczać kierunek, wówczas dziennik wciąż się zmienia i nie ma jednolitego kierunku, a wtedy przestaje zupełnie działać i przestaje być organem, a jest tylko kupą niepowiązaną szczegółów, toteż lepszy jest jednolity kierunek, choć słabszy, choć z błędami, aniżeli niejednolity z perfekcją. Dlatego to [... $]^{\mathrm{d}}$ rozpędził komitet redakcyjny mu narzucony. Otóż tego nie chce zrozumieć P[an] Pilat. I mimo tego, iż mi powtarzał, że komitet redakcyjny tylko jest dla mnie ciałem doradczym, on gwałtem mi usiłował objąć supremację w redakcji. Już dawniej ostrzegali mnie najpoważniejsi ludzie, że Pilat znanym jest z tego, iż gdzie tylko był przy dzienniku, tam najfatalniej bruździł i że „Przedświtowi” szkodzi to bardzo, iż wiedzą, że Pilat tam jest. Ale nie wierzyłem temu zanim na własnej nie doświadczyłem skórze tego miękkiego, słodkiego despotyzmu, tej zakulisowej ingerencji, a nawet w części zapewne niezawinionej intrygi. P[an] Pilat bowiem zwołał np. mych współpracowników i moich podwładnych, ażeby z nim omawiać redakcyjne rzeczy, przez co byli zbałamuceni kogo słuchać mają. P[an] Pilat Madurowicza interpelował, dlaczego mi dozwolił pomieścić ten czy ów artykuł, choć wie, że rzeczą Madurowicza jest nie dyskutować, lecz słuchać. P[an] Pilat, gdy się odważyłem radzić Kozłowskiego, jedynego katolickiego polityka (bo Pilat $\mathrm{w}$ polityce mimowiednie jest liberałem dawnej szkoły), wołał, że jemu niedowierzam i pogniewał się, a na mój list otwarty i jasny nawet nie raczył odpowiedzieć. Głosi zaś, że zaczyna być niepewny kierunek „Przedświtu” etc., że ja ufam Czerkawskiemu i inne historie. Taki jest stan rzeczy, który się czułem obowiązany Księdzu Arcypasterzowi przedstawić z prośbą, by bez niego porozumienia nie było nic w sprawie „Przedświtu” postanowionym. Z mej strony dodaję, że najchętniej się zgodzę na to, by grono ludzi czy robiło mi uwagi, czy błędy wytykało, czy zdanie co do pisma objawiało, gdyż to co innego rada życzliwych, co innego zachłanność polityka wybitnego, który swój kierunek chce przeforsować. Więc może się zbierze czy Dembiński ${ }^{90}$, czy Abraham ${ }^{91}$, czy

c Wyraz nieczytelny.

d Wyraz nieczytelny.

${ }^{90}$ Dembiński Bronisław (1858-1939), dr filozofii, w 1886 r. uzyskał habilitację na Uniwersytecie Jagiellońskim z zakresu historii oraz podjął tam wykłady, 1892-1919 prof. historii powszechnej na Uniwersytecie Lwowskim, w roku akad. 1907/08 r. rektor uczelni, w 1908/09 i 1909/10 prorektor, w 1898/99 r. dziekan Wydziału Filozoficznego, 1920-1923 wykładowca historii na Uniwersytecie Warszawskim, od 1923 r. związał się z Uniwersytetem Poznańskim; 1914-1918 poseł do parlamentu austriackiego, 1919-1922 poseł do Sejmu Ustawodawczego, 1918-1920 podsekretarz stanu w Ministerstwie WRiOP. J. Ziółek, Dembiński Bronistaw, w: EK, t. 3, red. zbior., Lublin 1985, kol. 1138-1139.

${ }_{91}$ Abraham Władysław (1860-1941), dr praw, w 1886 r. habilitacja na UJ, 1888-1935 prof. zwyczajny prawa kanonicznego na Uniwersytecie Lwowskim, w roku akad. 1899/1900 rektor, od 1893 r. członek Akademii 
Ks. Lenkiewicz, Ks. Sapieha i jeszcze może paru zaufanych, których atoli dobór mnie zarezerwowanym być musi. Przepraszam, że mą bazgraniną tyle zabrałem czasu, ale musiałem rzecz opisać.

Ucałowuję ręce z czcią najgłębszą, najoddańszy sługa

Ks. Teodorowicz

\section{Dokument 17}

\section{Najczcigodniejszy Księże Arcypasterzu!}

Jeśli mi tylko będzie możliwym, będę się starał być dzisiaj, gdyż jak wnoszę umyślnie Ksiądz Arcypasterz zaprosił nas dla narady w sprawie „Przedświtu”. Dziękuję serdecznie za list łaskawy, musiałem wszakże mój w wielkim pisać pośpiechu, skoro nie zostałem zrozumiany. Powiada Ksiądz Arcypasterz całkiem słusznie, że potrzeba wysłuchać zdania 2 partii, aby potem urobić swoje. Ale właśnie w liście pisałem do Księdza Arcybiskupa, że godzę się na grono ludzi, którzy mię radą wspierają. Właśnie napisałem, że i Dembińskiego, i Abrahama chętnie za takich przyjmę, gdyż ludziom tym o nic innego nie idzie jak o danie rady i wskazówki. Tylko dlatego z panem Pilatem być nie mogę, że on tej zasady uznać nie chce w praktyce choć ją powtarza w słowach. Wszakże o to poszło, że mu powiedziałem, iż nie mogę polegać w kwestii politycznej tylko na jego zdaniu, ale muszę się poradzić Kozłowskiego i posłów księży świeżo obranych. W liście ostatnim, na który mi nie odpisał wcale, właśnie mu powiedziałem, że cenię jego zdanie, ale muszę wysłuchać i strony przeciwnej. Więc Księże Arcypasterzu tu się zgadzam najzupełniej ze zdaniem Księdza Arcybiskupa i jeśliby tylko tak postępywał ${ }^{\mathrm{b}}$ Pan Pilat, byłaby między nami niezamącona zgoda. Mówi Ksiądz Arcypasterz, że Pilat mnie ceni. Alei i ja go cenię jako człowieka, jako katolika, jako męża nieposzlakowanego. To co mi tak niemożliwym czyni stosunek z nim jest tylko wypływem jego żyłki politycznej i jego zdecydowanego liberalno-konserwatywnego kierunku politycznego, który on mimowiednie ma i który gwałtem chce dziennikowi narzucić zapewne w najlepszej wierze, bo to w czym wzrósł, uważa sam za najlepsze. Dziwi się Ksiądz Arcypasterz, dlaczego zerwałem tak rychło z ludźmi, których tak niedawno do narad prosiłem. Najpierw nie z tamtymi zrywam tylko z Pilatem. Po wtóre całkiem co innego były narady nad praktyczną stroną dziennika, a całkiem co innego narada nad samym kierunkiem jego. Tam chodziło o kupiecką stronę rzeczy, że się tak wyrażę, tu zaś chodzi o sam rdzeń duchowy. Co do taktycznej strony dziennika, to w tej mierze błędy w początkach być

Umiejętności w Krakowie, 1922-1923 referent ministerialny ds. opracowania projektu konkordatu pomiędzy Polską a Stolicą Apostolską. Był twórcą nowoczesnej polskiej szkoły kanonistycznej. Publikował prace w zakresie prawa kanonicznego, historii Kościoła powszechnego i polskiego, historii Polski średniowiecznej, dziejów ustroju i dawnego polskiego prawa sądowego, historii literatury, językoznawstwa, historii liturgii, etnologii. J. Sawicki, Abraham Wtadystaw, w: EK, t. 1, red. zbior., Lublin 1985, kol. 25.

a Powyżej obcą ręką napisano czerwoną kredką rzymską cyfrę: „II”. List pisany jest na dwóch podwójnych, nieliniowanych kartkach formatu zeszytowego. Brak miejsca wystawienia dokumentu i datacji. Kartki posiadają znak wodny przedstawiający napis: „Victoria Note Paper”. 
muszą. Co innego, gdy w wir życia wchodzi. Zresztą to jest rzecz bardzo względna, co się błędem zwie taktycznym. Za artykuł przeciw „Czasowi” dostał „Przedświt” gratulacje z najpoważniejszych stron i od osób bardzo wybitnych, a tarnowska diecezja po tym artykule nawróciła się do „Przedświtu”. [... ${ }^{\mathrm{c}} \mathrm{w}$ swoim czasie (nie myślę się z nim równać, choć o nim piszę) posuwał się do tego, że walczył w „L'Umiere” ${ }^{\text {”g }} \mathrm{z}$ takim biskupem orleańskim, a jak silnie walczył - i nic. To, co uznałem za złe, było więcej ze względu na sąd Księdza Arcypasterza, który niesłychanie cenię, niż ze względu na me własne przekonanie. Zresztą na tego rodzaju błędy żaden komitet nie poradzi. Artykuły rodzą się w dzienniku pod wpływem chwili i nie ma nigdy czasu czekać na komitet. Komitet zawsze ma głos ex post. Zresztą gdyby nawet, co nie jest nigdy w praktyce, komitet przeszkodził artykułowi nietaktycznemu, to z drugiej strony uczyni on gorsze złe, bo żałuje łatwo skoro w nim są ludzie narzucający swe zdanie samą odpowiedzialność dziennika. Proszę, podam przykład. „Gazeta Kościelna” za Księdza Lenkiewicza zrobiła taktyczny błąd w walce z Luegerem, a potem $\mathrm{z}$ Gnatowskim ${ }^{93}$, a dzisiejsza nie robi błędów żadnych. Ależ właśnie dzięki, że powiem, temperamentowi, który tu i tam w błąd wystrzeli, tamta gazeta z błędami miała taką wyższość nad tą bez błędów. Każda indywidualność ma swoje słabe strony $[\ldots]^{\mathrm{d}}$. Każdy autor ma je w książce, którą pisze. Musi je mieć i dziennikarz. Trwożliwe usuwanie ich zabija temperament dziennika, bałamuci sąd redaktora i wytwarza dzienniki à la "Gazeta Narodowa" ${ }^{44}$ i „Przegląd”, bez barwy i życia. Gdy dziennik żyje musi tu i tam zbłądzić, bo gdy 10 razy decyduje na godzinę to przecie raz pobłądzi, ale właśnie trwożliwość i obawa Pilata lub jemu podobnych da dziennik może bez usterek, ale i bez zalet, bez czucia, bez życia. Najmocniej przepraszam za takie nadużywanie cierpliwości i łaskawości Księdza Arcypasterza.

\section{Z czcią najgłębszą najoddańszy sługa}

Ks. Teodorowicz

b Zgodne z oryginałem; poprawnie: postępował.

c Wyraz trudny do odczytania.

92 Tytuł niezidentyfikowany.

${ }^{93}$ Gnatowski Jan (1855-1925), studiował na Politechnice w Rydze, na wydziałach humanistycznych uniwersytetów w Wiedniu i Krakowie oraz teologicznym Uniwersytetu w Innsbrucku, święcenia kapłańskie w 1887 r., 1888-1890 sekretarz nuncjatury apostolskiej w Monachium, 1890-1905 katecheta szkół średnich we Lwowie, 1905-1925 na emeryturze w Warszawie; wydawca i redaktor periodyków: „Wiara”, „Przegląd Katolicki”, współpracownik „Niwy”, „Wieku” i „Ateneum”, był autorem nowel, powieści, publicystyki społeczno-kulturowej; odznaczony godnością prałata papieskiego. Wyróżniał się erudycją, kulturą umysłową, znajomością świata, we Lwowie prowadził salon literacki. A. Bednarek, Gnatowski Jan, w: EK, t. 5, red. zbior., Lublin 1989, kol. 1159.

d Tekst nieczytelny.

94 „Gazeta Narodowa” - dziennik ukazujący się w 1. 1862-1915 we Lwowie. Redaktorami byli: Ludwik Gumplowicz. Mieczysław Romanowski, Ludwik Powidaj, Jan Dobrzański. Do 1885 r. nakład wynosił 2500 egz., potem spadł do 1000 egz. W 1911 r. pismo zakupiła spółka reprezentująca skrajny odłam Podolaków tzw. Centrum (Stanisław Stadnicki, Władysław Czartoryski, Aleksander Krzeczunowicz). Prasa polska, passim: J. Jarowiecki, Prasa lwowska, s. 192-196.

95 Właściwie: „Przegląd Polski” - konserwatywny miesięcznik poświęcony polityce i literaturze, ukazujący się w l. 1866-1914 w Krakowie. Redaktorami byli: Stanisław Koźmian, Ludwik Powidaj, Ignacy Skrochowski, Stanisław Tarnowski, Józef Szujski, Jerzy Mycielski. Polskie czasopisma, passim. 


\section{Dokument 18}

\section{Najczcigodniejszy Księże Arcypasterzu! ${ }^{\mathrm{a}}$}

Jeszcze raz piszę, bo dotknął Ksiądz Arcybiskup [sprawy], z której poruszenia bardzo się cieszę, a w której lepiej mi jest pisać niż mówić.

Otóż pisze Ksiądz Arcypasterz gdzie był redaktor, który wiele artykuł[ów] Konecznego rzucił do kosza. Otóż tu został po prostu Ksiądz Arcybiskup okłamany przez Mycielskiego i Konecznego. Obaj ci panowie próbowali to samo ze mną zrobić. Ale zaraz wdrożyłem indygencję ${ }^{96}$, sprowadziłem do Konecznego i brata, i co się pokazało? Oto, że jeden jedyny artykuł Konecznego nie poszedł, a to z powodu, który Koneczny sam uznał za słuszny, mianowicie z powodu przedawnienia sprawy, bo była mowa o jakichś rozruchach studenckich, o których post factum Koneczny napisał. A więc czyż nie oczywiste i tendencyjne to kłamstwo obmyślone li tylko w tym celu ażeby brata w oczach Księdza Arcybiskupa zdyskredytować? To zaś, co Koneczny pisał Księdzu Arcybiskupowi, że jego planów i wskazówek redakcja nie uwzględnia odnosiło się do jego artykułów, z których jeden mnie przysłał, a drugi bratu dał, by były jako jego proponowane artykuły drukowane. W tym czasie, kiedy Koneczny mówił o masie artykułów zalegających, jeszcze ich nie było wcale. Brat ich nawet nie przeglądał tylko mnie oddał do rzeczy, ja zaś absolutnie zabroniłem drukowania ich, tak bowiem są napisane niezręcznie nie w duchu „Przedświtu”, że wystarczyłoby je pomieścić, aby się rozgłosiło, że „Przedświt” to pismo stańczykowsko-klerykalne.

Co do drugiego punktu, mianowicie kwestii, dlaczego brat artykuły jego pomieścił, to odpowiem na to po prostu, że brat uważając Konecznego za kierownika sam złożył władzę i do technicznej strony przeznaczył Madurowicza, aby nie sądził Koneczny, że może mu zależy na władzy. Ale swoją drogą pośrednio uwagi i przedstawienie brat mu robił, ale mając głos doradczy nie miał prawa przeszkodzić. Bratu jednak zawdzięcza „Przedświt”, że wymógł na Konecznym nienapisanie artykułu, którym Koneczny się gotował przeciw manifestacji mającej się odbyć w sejmie w sprawie Wrześni. Tym jednym artykułem byłby „Przedświt” w opinii raz na zawsze zabity. Uratował parę drobnych rzeczy, ale wszystkiego nie mógł, nie miał prawa, tym bardziej, że Mycielski wciąż pompował Konecznego i ten wygłaszał wobec brata i mnie hasła o absolutnej władzy w redakcjach. Więc co ma brat robić? Z jednej strony może go spotkać zarzut, że pismo opuścił, z drugiej, że za obecnością redaktora samego chce [coś] jeszcze mieć do gadania. Chciałbym jednak skorzystać z tej sposobności, ażeby odkryć Księdzu Arcypasterzowi rzecz, której dlatego nie poruszałem, że była dla mnie za drażliwa. Oto od roku jest formalna kampania przeciw mojemu bratu podjęta $\mathrm{z}$ jasnym planem i wytrwałością. Ksiądz Arcybiskup o tym nie wie, ale ja mam dziś w ręku wszystkie nici.

\footnotetext{
a List pisany na 12 stronicach kratkowanego papieru formatu zeszytowego. Brak miejsca wystawienia dokumentu i datacji. W lewym górnym rogu karty tytułowej obcą ręką niebieską kredką napisano: „Teodorowicz".

${ }^{96} \mathrm{Z}$ łac.: indigentia - potrzeba, brak; tu w znaczeniu: dochodzenie.
} 
To gwałtowne forsowywanie ${ }^{\mathrm{b}}$ Konecznego mnie i Księdzu Arcybiskupowi było, jak zaraz wykażę, tylko jednym pociągnięciem więcej.

Myliłby się jednak, kto by sądził, że tu chodzi o brata mego. Nie, tu w tej kampanii co do której odkryję zaraz Księdzu Arcypasterzowi ciekawe szczegóły, chodzi o coś całkiem innego. Oto ci panowie poznali, że ja się im nie dam użyć za narzędzia. Rozumieją, że „Przedświt” tak długo nie jest do wzięcia jak ja w nim jestem. Więc co robią? Oto uderzają na brata, by z chwilą jego wyrzucenia wysunąć i mnie $\mathrm{z}$ „Przedświtu”, a tym samym uczynić z gazety narzędzie dla swoich celów i dla swej polityki. Na tej widowni tajnej a ustawicznej kampanii występował głównie Stanisław Badeni ${ }^{97}$ i Pilat. Pieskiem szczekającym, użytym za ich narzędzie podrzędne był Przygodzki. Badeni poznał dawno, że ze mną nie poradzi [sobie], dał mi to nawet osobiście uczuć swoją indygnację ${ }^{98}$, a co do brata to otwarcie się rzucił na niego z chwilą, gdy jego mowę nie pomieścił w przeszłym roku całą, ale w streszczeniu. Jak Pilat czuwa nad „Przedświtem” do dziś dnia, na to mam najautentyczniejsze dowody. Zręczny ten człowiek nie uderza wprost. Oświadcza się, że z przyjaźni dla mnie i dbałości o dobro pisma byłby za tym, by zmienić redakcję. Tymczasem wchodzi poza plecyma ${ }^{c}$ brata w konszachty ze współpracownika$\mathrm{mi}$, a nawet $\mathrm{w}$ nieobecności brata bywa $\mathrm{w}$ redakcji, co wiem nie przypadkiem, dowiedziałem [się] od obcych ludzi, co go parę razy właśnie wtedy zastali wraz z Kuśmińskim, gdy brat wyjechał. Ja tu nie wyliczam wszystkich manewrów Pilata, ja mu się zresztą nie dziwię ani go oskarżam, bo rozumiem, że jako tęgiemu politykowi musi zależeć na opanowaniu pisma, ja tylko konstatuję, że kampania trwa. Przygodzki znowu użyty przez Badeniego i Pilata puszcza w obieg tysięczne plotki myszkując w redakcji i gdzie może tam osłabia brata.

Wszystko to miało cel jeden. Wyrzucić brata a wsadzić Madurowicza, którego kierunek konserwatywny i sympatie dla Badenich były tym panom aż nadto znane. Prawda, że charakter i uczciwość Madurowicza stanowiły pewne trudności. Z ust Madurowicza wiem o tym, że Pilat go buntował przeciw mnie wtedy, gdy byłem jeszcze redaktorem, mówiąc: „co pan się na księdza T[eodorowicza] masz oglądać” etc., ale Madurowicz się oparł. W każdym razie Madurowicz bezwiednie i nieświadomie sprzyjając osobiście Badeniemu (proszę uważyćd jak teraz w „Przedświcie” zarekomendował jego mowę i podał w całości), byłby o tysiąc procent wygodniejszy niż brat, za którym ja stałem.

Ja nie wiem, ani nie pytam o to, czy ci panowie i o ile w tym kierunku próbowali wpływać na Księdza Arcybiskupa. W każdym razie podziwiałem dobroć, cierpliwość i wyrozumiałość Waszej Arcypasterskiej Mości, skoro ciągle słysząc echa tego, co oni w kurs puszczali, czy bezpośrednio, czy pośrednio wciąż słysząc, że brat niezdarny, że

b Zapis zgodny z oryginałem; w znaczeniu: forsowanie, promowanie.

97 Badeni Stanisław (1850-1912), dr praw i dr filozofii, od 1883 r. poseł na Sejm Galicyjski, w 1891 r. wszedł dożywotnio do austriackiej Izby Panów, 1895-1901 i 1903-1912 marszałek Sejmu Galicyjskiego.

S. Starzyński, Badeni Stanisław Marcin, w: PSB, t. 1, red. zbior., Kraków 1935, s. 209-211.

${ }_{98} \mathrm{Z}$ łac.: indignatio - niechęć, niełaska, gniew.

Zgodnie z oryginałem; poprawnie: plecami.

d Zgodnie z oryginałem; w znaczeniu: zauważyć. 
nie ma człowieka, etc., etc. jednak na tyle jeszcze był względny, że nie dał mi tego tak bardzo poznać i odczuć.

Otóż tymi ciągłymi atakami tymi systematycznymi, a przeciw mej osobie pośrednio skierowywanymi strzałami, byłem zatrwożony. Przykro mi niewątpliwie było i to nad wyraz, i stanowiło ciągłą mękę dla mnie zasłaniać brata i jakby odpowiadać za wszystko, ale co głównie mnie niepokoiło to to, że się poważnie począłem obawiać, by ta sieć zręcznie oplątująca mnie nie stała się kiedy powodem naprężenia względem osób, na których przy jasnym dla mnie stosunku niesłychanie wiele mi zależało i zależy, i dla osobistych względów, i dla dobra sprawy a nawet Kościoła.

W tym czasie nawinęło mi się dwu ludzi: Mycielski i Koneczny. Otóż powiedziałem sobie: Mycielski niezwiązany z konserwatyzmem, a przynajmniej nieszkodliwy, niechaj figuruje, a Koneczny, który za pierwszym widzeniem pobieżnym mnie się podobał, niechaj redaguje. W ten sposób usunę brata, tę kość niezgody, usunę się i sam, ale za to będzie człowiek, który poprowadzi pismo w tym samym duchu i nie odda na pastwę czyhających na nie polityków. Myślałem sobie, że przy Konecznym wpływ dalszy więcej pośredni mój i Księdza Arcybiskupa zupełnie wystarczą.

Tymczasem co do Konecznego nastąpiło na całej linii rozczarowanie. Postępowało po jego tu pobycie crescendo ${ }^{99}$, szczegół dorzucał się do szczegółu i nareszcie utworzył mi się cały obraz człowieka w gruncie sądzę, że dobrego, w pewnej mierze zdolnego, ale z ogromnym brakiem zmysłu politycznego, z ogromną dozą próżności i pewności siebie, z ogromną nieścisłością w obowiązkach, z olbrzymią ignorancją dziennikarskiej techniki, który byłby zdolny pismo zabić zupełnie za 2 tygodnie redagowania bez możności poprawienia go kiedy i zrehabilitowania w opinii. Zresztą facta loquntur ${ }^{100}$. Pozornie ten Koneczny mówił, że będzie się radził nas obu. Ale de facto nie pytał się o nic ani Księdza Arcybiskupa ani mnie, a za to dawał się powodować takiemu głupiemu Mycielskiemu, o czym się naocznie przekonałem. To samo najzupełniej wystarczało, by Konecznego $\mathrm{w}$ interesie pisma się koniecznie pozbyć. Ale dziś, gdy w spokoju i skupieniu zbieram wszystkie rozrzucone szczegóły, widzę jeszcze jedno w całej sprawie.

Nie da się zaprzeczyć, że nigdy bym był mimo wszystko na tak wygórowane warunki Konecznego nie przystał i nigdy bym się był z układem nie spieszył, gdyby nie Mycielski. On to na mnie wciąż urgował, on wołał, że przystąpi do „Przedświtu”, gdy Koneczny będzie lub ktoś, kto podlega jego wpływom, on wreszcie poleciał do Krakowa by przyspieszyć wszystko. Otóż jakkolwiek mając nadzieję na Mycielskiego i Konecznego zadość czyniłem im obydwom, jednemu w warunkach, drugiemu w pośpiechu, to jednak nie rozumiałem osobliwszej animozji Mycielskiego do brata. Dziś przekonuję się, że Mycielski był tylko znowu narzędziem Abrahamowicza ${ }^{101}$. Sam Mycielski mi się przyznał, że się „radzi”, że z nim zawsze konferuje etc.

99 Wł.: wzrastając; tu w znaczeniu: stopniowo coraz głośniej.

100 Łac: fakty mówią same za siebie.

101 Abrahamowicz Dawid (1839-1926), Ormianin, 1869-1918 poseł do Sejmu Galicyjskiego i Sejmu Ustawodawczego, 1875-1918 członek austriackiej Izby Poselskiej, w 1906 r. prezes Koła Polskiego w Radzie Państwa, 1907-1909 minister dla Galicji. W Sejmie należał do grupy tzw. autonomistów. Pozostawił po sobie fundację dla ubogiej młodzieży. S. Starzyński, Abrahamowicz Dawid, w: PSB, t. 1, s. 9-10. 
A więc znowu dalszy ciąg tej samej akcji. Abrahamowicz przyjaciel Pilata chcący się gwałtem wpakować w „Przedświt” [... $]^{\mathrm{e}}$ o to, gdy byłem redaktorem, znowu wie, kto tu stoi w drodze. Tym jest nie kto inny, tylko ja, a ja tak długo jak brat. A więc usunąć mnie i to w ten sposób, bym jednak mimo faktycznego wysunięcia jednak przed opinią za pismo odpowiadał. Właśnie wczoraj i dzisiaj zbierając z pamięci różne inne drobne szczegóły do tego przekonania przybyłem. A więc nie dosyć by było zabicia pisma przez niezdarnego redaktora, stało by się ono nadto łupem ambicji politycznych. Oczywiście, że mówiąc tu ciągle „ja” i o sobie mówię w pojęciu ich, gdyż w rzeczy samej z wysunięciem mnie i brata utracą tym samym możność wpływu na pismo. Bo z chwilą, kiedy wtargnie do pisma konserwatywny kierunek cała wartość indywidualna „Przedświtu” dla Księdza Arcypasterza jest utracona i „Przedświt” miałby tylko co najwyżej dla Księdza Arcybiskupa tę wartość, co „Czas”102 dla Kardynała Puzyny.

Tymczasem teraz wręcz jest inaczej. Najpierw znosić się będziemy ze sobą, a potem gdyby doszło z „Przedświtem” do skutku, brat będzie się poczuwał do obowiązku ciągłego znoszenia się bezpośredniego z Księdzem Arcybiskupem, ja więc będę bronił inwazji konserwatyzmu i zasłaniał sobą, a Ksiądz Arcypasterz będzie się znosił z redakcją.

A teraz, co do przyszłości „Przedświtu”. Prenumerata styczniowa nie tylko, że nie przyniosła strat, ale około 100 nowych prenumeratorów zapewniła. Pismo stanowczo ma przyszłość, chodzi tylko o to, by się raz na coś zdecydować.

Co do mnie raz jeszcze powtarzam, że dla mnie osobiście nie jest pożądaną rzeczą istnienie „Przedświtu”. Nie tylko tyle męki mi to pismo sprawia, ale nadto trzyma na ciągłej uwięzi moją całą działalność, którą w pismo chcę czy nie chcę muszę utopić i bezpotrzebnie mnie naraża. Dla mnie osobiście gdyby mi chodziło o pismo wystarczyłby jaki dwutygodnik czy coś podobnego, żyłce pisania, gdyby na nią było czas, zadość by się stało. Ale dobro ogółu, jak to pisałem Waszej Arcypasterskiej Mości, przedkładam nad dobro moje osobiste, więc stawiam się najzupełniej do dyspozycji i decyzji Księdza Arcybiskupa.

Plan zaś co do pisma podałbym następujący. Nie jednego mieć redaktora, ale paru. Taka organizacja jest w „Kölnische Volkszeitung”103, w „L'Umiers” i wszystkich wielkich dziennikach. Więc tak:

I. Do działu politycznego bardzo wybitny polityk Dr Czerkawski. Nie puszczać go wszakże bez zastrzeżeń, ja wspólnie z Księdzem Arcybiskupem bylibyśmy najwyższą instancją.

e Tekst nieczytelny.

102 „Czas” - dziennik poświęcony polityce krajowej i zagranicznej oraz wiadomościom literackim, rolniczym i przemysłowym. Wychodził w l. 1848-1863 i 1864-1939 w Krakowie-Warszawie. Funkcję redaktorów pełnili: Lucjan Siemieński (1849-1852), Konstanty Sobolewski (1852-1854), Antoni Kłobukowski (1854-1864), Ksawery Masłowski (1864-1867), A. Kłobukowski (1867-1892), Michał Chyliński (1892-1899), Antoni Beaupré (1899-1900), Aleksander Szukiewicz. Po 1900 r.: M. Chyliński, Rudolf Starzewski, Witold Noskowski, Antoni Bassara, A. Beaupré, Jan Moszyński, Stanisław Kopernicki, Rudolf Osman, Aleksander Lekszycki, Michał Konopiński. Polskie czasopisma, s. 90.

${ }^{103}$ Kölnische Volkszeitung” - pismo założone w 1860 r. w Kolonii przez J. Bachem jako „Kölnische Blätter" stało się dziennikiem katolickim, w l. 1869-1933 nosiło tytuł „KV”. 
II. Dział kościelno-społeczny. Artykuły wychowawcze. O te postarałbym się ja mając do tego ludzi, a tylko dając kierunek, więc i z Ameryki mógłbym tym działem kierować. Mianowicie dostarczyłbym w miesiącu pewną liczbę artykułów określonych $\mathrm{z}$ tego zakresu. Oczywiście omawialibyśmy sprawy wspólnie. A te 2 działy mogłyby mieć podpodziały. Np. pani Hardorf ${ }^{104}$ mogłaby mieć akcję społeczną kobiet. Kwestie prawno-społeczne Halban ${ }^{105}$.

III. Dział [kulturalny] wziąłby mój brat. To jest ściśle dziennikarskie koncerty, teatraf, kronika. On ma obowiązek się starać, aby nie pominięto jakiej wiadomości co by pismo dyskredytowało, że się spóźnią z wiadomościami. On by miał z partiami do czynienia, na co osobno potrzeba kilka godzin dziennie, on by wycisnął całą inwencję na to, by ożywić pismo, czynić je interesującym i zawsze podobającym się nie tylko pewniej części czytelnikom, ale wszystkim. On by mógł też wziąć odpowiedzialność za to, że prowadzenie pisma nie przekroczy rocznie dodatku 12 tysięcy. Zostałaby tedy tylko strona materialna, ale tę byśmy musieli omówić osobno.

No, ależ nabazgrałem bez końca. Kończę, przepraszając za mitręgę łącząc najoddańsze wyrazy

Ks. Teodorowicz

Co do Rampolli ${ }^{106}$, to on doskonale wie o „Przedświcie” od Jaroszyńskiego ${ }^{107}$. Wprost mu kardynał oświadczył, że się cieszy „Przedświtem”, bo uważa istnienie tego pisma za dowód żywotności katolicyzmu u nas, a w szczególności dowód podatności dla idei Ojca Św[iętego] społecznych. To są jego ipsissime verba ${ }^{108}$ wedle Jaroszyńskiego. Oni tak mało wiedzą w Rzymie o nas, że niestety jedynym dla nich termometrem akcji katolickiej jest pismo i nie taję tego, że godzę się z Księdzem Arcybiskupem na to, że upadek pisma jest równocześnie utraceniem zupełnym kredytu episkopatu naszego w Rzymie.

104 Osoba niezidentyfikowana.

${ }^{105}$ Halban Alfred (1865-1926), dr praw, docent na Wydziale Prawa UJ, 1894-1905 prof. historii prawa niemieckiego i historii ustroju Austrii na Uniwersytecie w Czerniowcach, w roku akad. 1898/99 dziekan Wydziału Prawa, w 1905 r. prof. zwyczajny prawa porównawczego, później historii prawa niemieckiego na Uniwersytecie Lwowskim; 1919-1926 wykładowca historii prawa na Zachodzie Europy w Uniwersytecie Jana Kazimierza we Lwowie, w roku akad. 1908/09 dziekan, w 1919/20 rektor UJK, 1904-1910 poseł do Sejmu Bukowińskiego, 1908-1914 poseł do Sejmu Galicyjskiego, 1911-1918 poseł do parlamentu austriackiego, potem do Sejmu Ustawodawczego RP. K. Koranyi, Halban Alfred, w: PSB, t. 9, red. zbior., Wrocław-Kraków-Warszawa 1960, s. 243-244.

f Zgodnie z oryginałem; w znaczeniu: teatry.

${ }^{106}$ Rampolla del Tindaro Mariano (1843-1913), święcenia kapłańskie w 1866 r., w 1882 r. mianowany nuncjuszem, w 1887 r. kreowany kardynałem i sekretarzem Stanu Stolicy Apostolskiej; zwolennik normalizacji między Stolicą Apostolską a rządem włoskim i Francją. Przeciwko jego wyborowi na papieża w 1903 r. cesarz austriacki za pośrednictwem kard. Jana Puzyny z Krakowa wniósł na konklawe veto. A. Posch, Rampolla del Tindaro Mariano, w: LThK, Bd. 8, herausg. von J. Höfer, K. Rahner, Freiburg im Br. 1986, kol. 985-986.

107 Jaroszyński Edward (1865-1907), ziemianin, pisarz, działacz społeczny, popularyzator katolickiej nauki społecznej. Napisał m. in.: Leon XIII i demokracja chrześcijańska (1899), Katolicyzm socjalny (t. 1-2, 1901), Historia akcji katolickiej spotecznej przed Leonem XIII (1907). Z. Skwierczyński, Jaroszyński Edward, w: EK, t. 7, red. zbior., Lublin 1997, kol. 1053-1054.

${ }^{108}$ Lac.: własne słowa. 
Proszę się nie męczyć odpowiedzią, ja przybędę. Jeszcze zanadto dziś jestem osłabiony, więc może jutro. Jeszcze w planie redakcji opuściłem reportera. Musi być dobry. Ten np. mimo osobnego polecenia brata, by dał najdokładniejsze sprawozdanie z uroczystości Żyły ${ }^{109}$, gdzie był Ksiądz Arcypasterz, podał względnie ogólnikowe, a na odwrót, co do mnie przekręconym została zupełnie moja odpowiedź dana Małachowskiemu ${ }^{110}$, której sens był zupełnie inny.

\section{Dokument 19}

\section{Najczcigodniejszy Księże Arcypasterzu! ${ }^{\mathrm{a}}$}

Bardzo dziękuję za uwagi. Z Adamskim ${ }^{111}$ nie ma rady, gdyż pracy jego absolutnie nie można brać do „Przedświtu”, bo to i ciężkie, i zawiłe, i z pieczęcią jezuity, „Gazeta Narodowa” bierze zaś jedynie dla reklamy. Jeszcze z nim pomówię. Błąd się wkradł dziś o Ks. Wałędze, „miły” ksiądz. Co do nadesłanego oczywiście nie widziałem tego przedtem, zrobiłem też zaraz dochodzenie i pokazało się, że to sobie żarta ${ }^{\mathrm{b}}$ zrobiły znajome mi same panienki z kuzynem, którego zowią żartobliwie opiekunem. Ale notabene to nie powinno być i na przyszłość nie będzie. Jeszcze chciałem Księdzu Arcybiskupowi zwrócić uwagę na Milskiego. Jest to człowiek niesłychanie sprytny i nie tyle zły on na "Gazetę", ile na „Przedświt”, który mu podbiera prenumeratorów. Boję się, czy on z gotowym planem nie idzie do Księdza Arcybiskupa. Mianowicie Chęciński ${ }^{112}$ się bronił czy mówił ogólnie, że odezwy przeciw „Ruchowi” są za wiedzą Księdza Arcybiskupa. Tak też było, choć mimo wiedzy i przeciw woli była jazda na dziennik. Ale jedno z drugim jest złączone, gdyż Ksiądz Arcybiskup dał ogólny plan, a nie dał szczegółów i w tych właśnie szczegółach rzecz została popsuta. Milski zaś w miłej spółce z Ks. [...] ${ }^{\mathrm{c}}$ zrobili

109 Postać niezidentyfikowana.

110 Małachowski Godzimir (1852-1908), dr praw, adwokat i członek lwowskiej Izby Adwokackiej, od 1892 r. członek Rady Miejskiej Lwowa, 1896-1905 prezydent Lwowa; za jego kadencji zbudowano m. in. wodociągi, tramwaj elektryczny i teatr miejski oraz liczne pomniki; od 1896 r. poseł do Sejmu Galicyjskiego, od 1904 r. poseł do Rady Państwa, członek Koła Polskiego. J. Zdrada, Małachowski Godzimir, w: PSB, t. 19, red. zbior., Wrocław 1974, s. 390-392.

a Powyżej adnotacja pisana ręką abp. Bilczewskiego: „Odnośnie do notatki w Gaz[ecie] Kośc[ielnej]. Początek. L.A., a także obok niebieską kredką napisane jest nazwisko: „Teodorowicz”. List pisany jest na podwójnej, nieliniowanej kartce formatu kieszonkowego. Znak wodny przedstawia zdobiony napis: „Original Fiume-Mill." Brak miejsca wystawienia dokumentu i datacji.

111 Adamski Józef Stanisław (1851-1926), święcenia kapłańskie w 1881 r. w Zakonie oo. Jezuitów w Krakowie, 1873-1880 wykładowca j. niemieckiego w Vannes (Bretania), j. francuskiego w Kalksburgu (18821883), religii i filozofii w gimnazjum w Tarnopolu (1884-1885), j. francuskiego w gimnazjum w Chyrowie (1893-1894). Był znanym kaznodzieją w Krakowie, Lwowie, Czerniowcach, Zakopanem, Nowym Sączu i Czechowicach; autor wielu książek i broszur o tematyce filozoficzno-teologicznej, społecznej i ascetycznej. Adamski Józef Stanistaw, w: EWJ, s. 2.

b Zgodne z oryginałem; w znaczeniu: żarty.

112 Chęciński Józef (1856-1918), święcenia kapłańskie w 1883 r. we Lwowie, proboszcz parafii pw. Matki Bożej Śnieżnej tamże, redaktor odpowiedzialny „Gazety Kościelnej” w 1. 1898-1906. J. Jarowiecki, Prasa lwowska, s. 182; Schematismus [...] 1883-1918, passim.

c Nazwisko nieczytelne. 
mnie po prostu szachrajem, który okłamał Chęcińskiego. Otóż Milski chce pewnie jeszcze w słowach Arcypasterza aprobaty dla siebie, a raczej dla mnie na ten przyzwoity epitet. Otóż prosiłbym bardzo Księdza Arcybiskupa o jakąś wymijającą odpowiedź co do nieszczęsnej ciemnej karty z „Gazetą Kościelną”. Zaczyna się druga faza dla „Przedświtu”. Z początku kpiły zeń nasze gazety, potem milczały, a dziś się poczynają irytować. To dobry znak! Poczciwy „Czas” dzięki naszym artykułom wydrukował list pasterski ${ }^{113}$ Księdza Arcybiskupa. Zaczyna się nas bać. No, alem nabajał co się wlezie.

Rączki ucałowuję Arcypasterskie. Najoddańszy sługa

Ks. Teodorowicz

\section{Dokument 20}

Najczcigodniejszy Księże Arcypasterzu! ${ }^{a}$

Nie mam dotąd wiadomości od Mycielskiego, a więc tym większe dziś jest prawdopodobieństwo, że ostateczne załatwienie sprawy i zdecydowanie „tak” albo „nie” spoczywa zupełnie wyłącznie w ręku Księdza Arcybiskupa. Ażeby decyzję ostateczną ułatwić Waszej Arcypasterskiej Mości, zbieram raz jeszcze w jeden obraz częścią omawiane już, częścią nieomawiane rzeczy. Popróbuję podać résumén ${ }^{114}$ całości.

Otóż przede wszystkim chciałbym, by w podjęciu ostatecznej decyzji Ksiądz Arcybiskup niczym zgoła nie był krępowany, nawet względami osobistymi co do mnie. Dlatego na wstępie oświadczam, że ja osobiście nie mam żadnego interesu w prowadzeniu nadal „Przedświtu”, owszem wszelkie moje osobiste względy przemawiają wręcz inaczej. Bo i proszę uważyć:

1) Jak długo jestem przy „Przedświcie”, tak długo odpowiedzialność choćby częściowa za tak wielką żywą machinę jest na mych barkach. Moją działalnością, moją pracą pisarską nie mogę rozporządzać jak chcę, ale przynajmniej w znacznej części staję się niewolnikiem gazety. Dotąd sam sobie tę cząstkę obrałem. Ale na nowym stanowisku ${ }^{115}$ taka ofiara nie jest bagatelą.

2) Ludzie patrzący na mnie dotąd przez pryzmat „kapłana”, widzący mnie zawsze w pracach bezpośrednio kapłańskich od roku poczęli patrzeć przez pryzmat lekceważonego „dziennikarza”. To mnie obniżyło w pojęciu najlepszych, a naraziło na szykany i ataki. Rzecz oczywista, że mój interes osobisty domaga się, by ta tradycja co rychlej przeciętą została, a to się stanie najdosadniej ze zniknięciem z widowni „Przedświtu”.

3) Gdybym więcej dbał o wpływ zewnętrzny jak dbam, to bym sobie już przed pół rokiem winien był powiedzieć: „zwiń Przedświt, bo jak świeca z łoju, tak to pismo żyje

${ }_{113}$ Prawdopodobnie chodzi o przesłanie abp. J. Bilczewskiego: W sprawie nauczania katechizmu. List pasterski do wiernych archidiecezji, Lwów 20 I $1901 \mathrm{r}$.

a List pisany na 9 podwójnych, nieliniowanych kartkach formatu kieszonkowego. Wszystkie kartki posiadają znak wodny z napisem: „Original Margaret Mill” oraz zgeometryzowany potrójny kwiat.

114 Fr.: streszczenie.

115 Aluzja do objęcia przez abp. J. Teodorowicza stolicy arcybiskupów lwowskich obrządku ormiańskokatolickiego w $1901 \mathrm{r}$. 
z twojej popularności czy twojego imienia, a mianowicie żyje kosztem jego". To przecie mówił mi teraz we Lwowie Sam Ksiądz Arcybiskup. Nawet dzienniki katolickie szachowane „Przedświtem” tyle mi niechęci okazywać będą przy jego istnieniu, ile mi okażą sympatii z jego zniknięciem. A przeciw tym pociskom nawet się bronić nie mogę. Bo z mej roli to wynika, iż o ile podnosić mam obowiązek wszędzie osobę Księdza Arcybiskupa, o tyle muszę najskrupulatniej ukrywać siebie.

4) Dziś po krachu bankowym muszę u rządu żebrać o niejedno. „Przedświt” do tego jest przeszkodą. Piętak wprost powiedział jednemu z posłów, że uważając mnie za redaktora pisma ociągano się z moją nominacją ${ }^{116}$.

Nie chcę nużyć Księdza Arcybiskupa rozwlekaniem tych rzeczy, ale to już chyba aż nadto wystarczy. I niechaj mi wierzy Ksiądz Arcybiskup, gdybym nic innego nie czynił, tylko te artykuły, które starannie ukrywam w „Przedświcie” rozdawał to tej, to owej redakcji, to nie tylko pozyskałbym je wszystkie dla mej osoby, ale i wpływ mego słowa pisanego o tysiąc procent byłby skuteczniejszy, a przynajmniej rentowniejszy. Zostawałyby co prawda ze zwinięciem „Przedświtu” skrupuły co zrobić z bratem, którego wycofałem z jego zajęć, a wprowadziłem w dziennikarstwo? Jest to wzgląd oczywiście drugorzędny, ale i ten zupełnie upada, skoro wezmę to na uwagę, iż on się tak już wybił w świecie dziennikarskim, że już tam nawet dziś wszędzie będzie poszukiwany z chwilą zwinięcia „Przedświtu”, a w razie jakiej fuzji, on przecie zostanie. Nie dziw więc, że głos moich przyjaciól, głosy diecezjan, którzy z deputacją osobną mieli być u mnie w tej sprawie są jak jeden za tym, by „Przedświt” zwinąć i to przed konsekracją.

Co mnie jednak mimo wszystkich tych względów przy piśmie trzyma? Niezawodnie pewne przywiązanie do dziecka mego ducha. Ale dziś tyle racji mówi przeciw temu, że choć nie bez cierpienia w[e]nętrznego, ale gotów zupełnie jestem zrzec się takowego. Główny atoli powód to jest sumienie. Ono mi mówi: „twoje osobiste względy muszą ustąpić na miejsce drugie wobec sprawy. Mniejsza ostatecznie o ciebie, zwłaszcza w chwili, gdy episkopat tak jest obsadzony jak jest, ale nie mniejsza o pismo, które jest głosem wciąż mówiącym Kościoła”. I oto ten wzgląd rozstrzyga. Po prostu nie miałbym spokoju sumienia, żem dla względów osobistych zaprzepaścił sprawę Bożą. Z chwilą tą jednak gdy zobaczę, że mimo wszystko pismo nie ma gwarancji pomocy, z chwilą gdy nie ma gwarancji materialnej, z tą chwilą mówię skrupuły me upadają gdyż ad impossibilia nemo tenetur ${ }^{117}$ tą chwilą jestem najzupełniej dziś zdecydowany poczynić kroki do natychmiastowej likwidacji.

Dziś nawet się nie zadowolnię niczym problematycznym, kwestię muszę mieć postawioną jasno aut aut ${ }^{118} \mathrm{i}$ zdecydowaną przed konsekracją, a że ta właśnie sprawa spoczywa w rękach Księdza Arcybiskupa, a więc proszę rzecz rozważywszy rozstrzygać; na to, czy na owo jestem najzupełniej przygotowany.

116 Elekcja abp. J. Teodorowicza miała miejsce 30 V 1901 r., prekonizacja - 16 XII 1901 r., konsekracja 2 II $1902 \mathrm{r}$.

117 Łac.: do rzeczy niemożliwych nikt nie jest zobowiązany.

b Zgodne z oryginałem; w znaczeniu: zadowolę.

118 Łac.: albo, albo. 
Ale skoro już mowa o względach osobistych to mimo woli ciśnie się pod pióro ta uwaga, że wręcz odwrotny jest stosunek osobistych względów u mnie, a u Księdza Arcybiskupa. Pozwoli Ksiądz Arcybiskup, że jakkolwiek nic mi do tego, to jednak nie pominę i tych pobudek, o których oczywiście sądzę podług siebie. I tak u Księdza Arcybiskupa wskutek zewnętrznych okoliczności to właśnie staje się korzystnym, co dla mnie niekorzystnym i na odwrót.

Bo proszę zważyć. Istnienie dziennika, jako organu Księdza Arcybiskupa ułatwia ogromnie Księdzu Arcybiskupowi wejście co rychlejsze i zżycie się ze społeczeństwem, na co we zwykłej normalnej drodze więcej potrzeba czasu. To jest tym więcej potrzebne skoro się zważy, że Ksiądz Arcypasterz więcej miał skierowaną czynność w pracę umysłową, a więc był bardziej znany elicie inteligencji niż ogółowi.

Dalej, przy metropolii Ksiądz Arcypasterz potrzebuje prowadzić politykę osobną jak np. z Czerniowcami ${ }^{119}$, dalej potrzebuje Ksiądz Arcypasterz pisma, by w nim jako w środowisku duchownych idei wciąż brzmiały echa jego słów etc.

Proszę zważyć, że już w tym jednym roku każdy występ ważniejszy Księdza Arcybiskupa był opatrzony artykułem osobnym, najczęściej wstępnym (trzy sam pisałem, o innych wiedziałem). Ale pomijam już to wszystko.

Sam duch opozycyjny pisma jest szczególniej pomocny Księdzu Arcybiskupowi. Bo tym więcej odwraca mniemanie ogółu od wyobrażenia, jakoby Ksiądz Arcypasterz był Biskupem bardziej rządowym. Proszę darować może za wielkiej otwartości, ale ocieram się o ludzi i wiem, co mówią.

Obawa zaś, że się komuś narazi Ksiądz Arcypasterz jest najzupełniej płonna. To ja się narażam, bo za bezpośrednio mnie z „Przedświtem” związano i już odwiązać się nie mogę. Ale całkiem inna jest rola tego, który ma gazetę jako organ.

Co zaś do uczynności, to ci ludzie przez obawę do tej uczynności tym skorsi. Korytowski ${ }^{120}$ i tak nic z miłości nie daruje, ale ot sam przychodzi, by się ekskuzować ${ }^{121}$. Nawet ton demokratyczny pisma czyni Księdza Arcybiskupa popularnym w tej części kraju, w której jest i w której jest ognisko demokracji.

Na odwrót, pismo połączy się z narodówką (innej drogi wyjścia nie ma), to znów najniepotrzebniej w świecie połączą Księdza Arcybiskupa z namiestnikiem ${ }^{122}$. Nie na wiatr to mówię. Ile to razy musiałem o to kopię kruszyć z ludźmi twierdzącymi, że

119 Czerniowce na Bukowinie; prowincja ta podlegała do 1925 r. jurysdykcji arcybiskupów lwowskich ob. łac. Zamieszkana w dużej mierze przez katolików pochodzenia niemieckiego, wykazywała znaczne tendencje separatystyczne, zmierzające do utworzenia odrębnej diecezji. W czasie pontyfikatu abp. Bilczewskiego funkcję wikariusza generalnego Bukowiny sprawował ks. infułat Józef Schmidt (1850-1921).

${ }^{120}$ Korytowski Witold (1848-1923), dr praw, urzędnik austriackiego Ministerstwa Skarbu, 1891-1908 szef tego resortu, 1907-1913 poseł do Rady Państwa, od 1908 r. poseł do Sejmu Galicyjskiego, 1913-1915 namiestnik Galicji, od 1915 r. członek Izby Panów Rady Państwa, od 1919 r. osiadł w Poznaniu włączając się w proces odbudowy gospodarki Wielkopolski. J. Buszko, Korytowski Witold, w: PSB, t. 14, red. zbior., Wrocław-Warszawa-Kraków 1968, s. 155-157.

121 Z fr. przestarzałe: tłumaczyć się, usprawiedliwiać, przepraszać.

122 Aluzja do bliskich relacji przyjacielskich łączących abp. Bilczewskiego z namiestnikiem Galicji Leonem hr. Pinińskim. 
namiestnik odkrył Księdza Arcybiskupa ${ }^{123}$. Dziś właśnie talenta i przymioty Księdza Arcybiskupa zbyt są jawne światu, by potrzeba ci walczyć o to, ale zawsze ludzie są ludźmi. Nie uwierzy Ksiądz Arcybiskup, jakie drobiazgi im do sądu wystarczą. Np. ten szczegól, że Ksiądz Arcybiskup mowę na zakończenie sejmu robił w pokoju namiestnika już wystarczył, by o Księdzu Arcybiskupie mówiono, że chadza na pasku Pinińskiego. Być może, że za czarno widzę, ale wolę przesadzić w skrupułach jak w lekceważeniu, zresztą Ksiądz Arcypasterz sam jest kompetentniejszy w tych rzeczach niźli ja. Moją raczej jest rzeczą te ogólne przedstawić względy, które właśnie jak zmora mnie trzymają i nie pozwalają lekkomyślnie puścić pisma z ręki, a nawet dla ważnych pobudek moich osobistych. Oto przede wszystkim upadek katolickiego pisma w obecnej chwili nie tylko jest bogactwem jednego doświadczenia więcej, ale jest niestety uniemożliwienie doświadczenia z katolickim pismem na jakie pół roku. Jest to prawda, przeciw której nic powiedzieć się nie da. Gdyby dziś zbankrutował "Naprzód”124 - to to bankructwo będzie nie tylko bankructwem jednej gazety, ale „idei”, ale partii samej. To samo ma się z nami. Upadek „Przedświtu” jest upadkiem sprawy katolickiej u nas i dowodem, że nie mamy żywotności w sobie.

Co smutniejsze, że się to stanie w przededniu kulturkampfu (załączam tu „Germanię"125, by widział Ksiądz Arcybiskup, że katolicy niemieccy trochę inaczej sądzą p[ana] Körbera ${ }^{126}$ niż my, zresztą i bez Körbera do tego idzie, w chwili najcięższej walki zostaniemy bez broni i bez oręża).

Poza tym zasadniczym punktem są jeszcze inne:

1) Gazeta katolicka to dowód żywotności katolickiej zagranicą. Kardynał Rampolla dowiedziawszy się od Jaroszyńskiego o „Przedświcie” powiedział: „no to przecie się ruszacie, dlaczegóż nic o tym nie mówicie”.

2) Ale nadto specjalnie „Przedświt” ma tę wielką i ważną misję, ażeby ideę Kościoła zdyskredytowaną przez konserwatyzm i „Czas”, który ją wziął w arendę okazać społecznie żywotną dla mas całych demokracji, dla całych zastępów wreszcie tych katolików u nas, którzy nie chcą iść na pasku partii krakowskiej, a żądną dlatego, że sama idea Kościoła jest ciasna i niewystarczająca. Mówiłem Księdzu Arcybiskupowi, co mi mówił

${ }^{123}$ Nawiązanie do genezy elekcji abp. J. Bilczewskiego na arcybiskupstwo lwowskie. Notabene - o czym już wcześniej wspomniano - opinia przytoczona tu była prawdziwa.

124 „Naprzód” - dwutygodnik polityczny i społeczny ukazujący się w Krakowie, Lwowie i Warszawie w l. 1892-1939, wznowiony w l. 1945-1948; od 1895 r. tygodnik, od 1900 r. dziennik; organ prasowy partii robotniczej. W redakcji pracowali m. in.: Ignacy Daszyński, Jan Englisz, Jan Serkowski, Kazimierz Kaczanowski. Nakład wynosił w 1914 r. 6000 egz. Polskie czasopisma, s. 399-400; Prasa polska, passim; J. Jarowiecki, Prasa lwowska, s. 271-272.

125 "Germania” - niemiecki dziennik wychodzący w 1. 1871-1938 w Berlinie, organ prasowy „Centrum” do 1933 r.; później przeszedł na pozycję ideologii narodowego socjalizmu.

126 Właściwie: Koerber Ernest von (1850-1919), dr praw, od 1874 r. urzędnik Ministerstwa Handlu, od 1897 r. szef sekcji Biura, od 1895 r. dyrektor generalny kolei austriackich, od 1897 r. minister handlu, od 1900 r. szef rządu austriackiego i minister spraw wewnętrznych, od 1902 r. minister sprawiedliwości, w 1915 r. minister finansów, w 1916 r. kilka miesięcy premier. R. Lorenz, Koerber Ernest von, w: ÖBL, Bd. 4, herausg. von L. Santifaller, Wien-Köln-Graz 1969, s. 44-45. 
poseł Schätzel ${ }^{127}$ : „nie miałem dotąd pojęcia o tym, by można było pogodzić Kościół i katolicyzm z wolnością i demokracją. «Przedświt» jest dla mnie rewelacją".

3) Ten całkiem nowy, świeży powiew przyszłości czuć w tym piśmie, które jak słusznie powiedział Baupré ${ }^{128}$ ma swój odrębny typ już dzisiaj.

4) „Przedświt” byłby specjalnie tym, czym nie zawsze jest każdy katolicki dziennik, byłby półurzędowym organem episkopatu. (Dodaję półurzędowym dla odróżnienia od całkiem urzędowego. Gdyby był bowiem oficjalnym, straciłby na żywotności, stałby się nudnym przez konieczność wielkiej powagi, a potem dobrze jest powiedzieć coś przez dziennik czego się nie może powiedzieć prywatnie).

5) W końcu „Przedświt” jest pismem będącym już dzisiaj w ręku świeckich.

A teraz co do przyszłości pisma. Rozbiorę szczegółowo takową. Oto przede wszystkim redakcja ma kombinację brata i Konecznego. Mówiłem o tym z Madurowiczem, który nie owija rzeczy w bawełnę, a ma w tej mierze bardzo dobry i trafny sąd. Otóż on powiedział, że taka kombinacja byłaby idealną, bo to są jego słowa: „brat ma bardzo zdrowy zmysł i rozsądek praktyczny, a Koneczny znowu czynnik przedstawia więcej naukowy". Słowem czynnik praktyczny reprezentowany w moim bracie z dodatkiem rzadkiego talentu dziennikarskiego i sprytu dziennikarskiego złączony z idealizmem Konecznego, który wedle ks. Zbyszewskiego ${ }^{129} \mathrm{w}$ tej mierze ma wielkie dane, jest wygraną.

Brat by brał rzecz z praktycznej strony wnikając w życie i szczegóły, on z teoretycznej, a nadto pisałby artykuły (4 tygodniowo) głównie w tym guście, jak tego pragnął Ksiądz Arcybiskup, wychowujące.

Co do polityki austriackiej i krajowej, to miałbym do tego zebrane już siły i w chwili, gdy się zdecyduję, że „Przedświt” ma istnieć dalej, układam się z tymi ludźmi. Dla wpływu pisma, a w szczególności dla polityki Kościoła w Austrii jest to rzecz niesłychanej wagi. Wszelkie nasze konserwatywne gazety („Przegląd”, „Gazeta Narodowa”, „Dziennik") są kupione przez rząd, a obsłużone niżej krytyki. Miałbym do tego najwybitniejszą zdolność polityczną w Krakowie, dalej Madurowicza, potem drogi do wybitnego korespondenta szwajcarskiej gazety, wreszcie do polakac ${ }^{c}$, który jest korespondentem z Austrii do „Figara” ${ }^{30}$.

127 Schätzel Stanisław (1856-1942), polski adwokat, 1895-1914 poseł do Sejmu Krajowego we Lwowie, zmarł w 1942 r. tamże. Źródło: Stanisław Schätzel, https://pl.wikipedia.org/wiki/Stanisław_Schaetzel_ (1856-1942). Dostęp 15 I 2017 r.

128 Właściwie: Beaupré Antoni (1863-1937), dr praw, publicysta, redaktor naczelny „Czasu” (1899-1900), „Głosu Narodu” (1900-1908), „Nowej Reformy” (1920-1937), 1914-1917 członek Naczelnego Komitetu Narodowego, 1918-1919 prowadził kampanię prasową na rzecz Polski i uczestniczył w debatach pokojowych w Paryżu, komisarz plebiscytowy na Mazurach, wieloletni prezes Syndykatu Dziennikarzy Krakowskich, członek Związku Obrony Kresów Zachodnich, od 1910 r. członek Rady Naczelnej Stronnictwa Prawicy Narodowej, 1933-1937 analogicznie w Zjednoczeniu Zachowawczych Organizacji Politycznych. Beaupré Antoni, w: Czy wiesz kto to jest?, red. S. Łoza, Warszawa 1937, s. 32.

129 Postać niezidentyfikowana.

Zgodne z oryginałem - tak konsekwentnie dalej; poprawnie winno być: Polaka.

${ }^{130}$ Fr.: „Le Figaro” - wpływowy prawicowy dziennik francuski założony w 1826 r., w l. 1854-1866 tygodnik satyryczny, od 1866 r. dziennik poranny, w l. 1942-1944 nie ukazywał się, po czym został wznowiony; wychodzi do dziś. 
Co do ruchu katolickiego świata to i tego nie zaniedbałem. Wchodzę w związek $\mathrm{z}$ wielkimi katolickimi dziennikami i w zamian za ich korespondencję dając nasze, mam nadzieje wzbogacić ten dział całkiem oryginalną a bogatą zastawą. Z Rzymu już zamówiłem polaka zmartwychwstańca, który oryginalne rzeczy pisuje, nadto drugiego francuza ${ }^{d}$ będą rzeczy z ruchu socjalnego we Włoszech. Z Belgii, Paryża, Niemiec, Szwajcarii będą korespondencje o tamtejszym ruchu i akcji socjalnej.

Aby nie rozwlekać wiele, mam nadzieję, że w dwu latach „Przedświt” stanie się dziennikiem, który skupi ludzi i z którym cała liczyć się będzie opinia. Koneczny wprost zobowiązuje się także do tego.

Ale to jest bilans pisma duchowy. Pozostaje bilans materialny. Otóż trzeba było całej ignorancji Pilata i mojej, by być tak naiwnym i chcieć za 15 tysięcy dziennik zakładać. „Ruch Katolicki” zjadł przecie coś przeszło 40 tysięcy - „Nowa Reforma” w 1-szym roku kosztowała 30 tysięcy. „Przedświt” wyszedł stosunkowo dobrze zwłaszcza skoro się zważy, że miał on drugie jeszcze zadanie, a tym było zabicie „Ruchu Katol[ickiego]”. Jest to akcja, która pozornie nie kosztowała, ale w rzeczy samej kosztowała wiele. Niech Ksiądz Arcypasterz przypomni sobie, że „Przedświt” powstał w chwili, gdy Zawadzki zdefraudował - więc był złożony z konieczności na poczekaniu, bez przygotowania, a to musiało kosztować.

"Ruch” się organizował coś zdaje mi się przez dwa lata, „Przedświt” musiał wyjść w paru tygodniach. Taka improwizacja pisma musiała się odbić na nim finansowo. W każdym razie zdobycie przeszło 2 tysiące prenumeratorów w roku pierwszym jest $\mathrm{w}$ annałach dziennikarstwa rzeczą niebywałą. Jest to dziś bardzo poważny kapitał pisma. W razie jakiej katastrofy (choć ta po ludzku mówiąc wykluczona) za 2000 tysięcye prenumeratorów wszędzie zapłaconą dobrze, tym bardziej, że ci zebrani pod sztandarem katolicyzmu zawsze są pewni.

Teraz jest wszelka nadzieja, że jak dotąd tak i na przyszłość prenumeratorowie ${ }^{f}$ będą rosnąć. Gdyby jeszcze tysiąc przybyło, byt pisma jest już zapewniony nawet w najgorszym razie i bez subwencji, zwłaszcza gdy pismo drukarnię posiadać będzie. Nie chcę i nie mogę obiecywać złotych gór, ale mam nadzieję wszelką, że zdobycie tysiąca prenumeratorów przy pewnej presji na księży, przy pewnej agitacji da się bez trudu osiągnąć wielkiego, a i w niedługim czasie.

Z tego już wszystkiego aż nadto wyraźnie może zważyć Ksiądz Arcybiskup, że wyrobienie pismu takiemu jak „Przedświt” pożyczki (u nas nie ma pisma prawie bez kilkudziesięciotysięcznej pożyczki, „Głos Narodu” czy o „Gazecie Narodowej” nie mówię) pożyczki trzydziestotysięcznej nie może nawet ryzyka przedstawić sądząc ponad spodziewanym sukcesie pisma i po idei, którą pismo przedstawia, która to idea u nas ogromną ma przyszłość i trwałą przyszłość. Gdyby zaś kto w najczarniejsze chciał się bawić horoskopy to i myślał o bankructwie pisma, to jeszcze w chwili nawet bankructwa za

\footnotetext{
d Zgodne z oryginałem; poprawnie powinno być: Francuza.

e Zapis zgodny z oryginałem.

f Zapis zgodny z oryginałem; poprawnie powinno być: prenumeratorzy. Sens zdania: liczba prenumeratorów będzie się powiększać.
} 
pismo (za 2 tysiące prenum[eratorów] biorę minimum stałe) weźmie się jakich 20 tysięcy, a reszta w paru latach niewątpliwie się wypłaciła. Ale nawet gdybym jeszcze dalej poszedł, gdybym powiedział Księdzu Arcybiskupowi proszę dać pożyczkę nie myśląc o „Przedświcie”, ale we własnym interesie i na dzieło, o którym Ksiądz Arcypasterz marzy - na drukarnię, to jeszcze miałbym rację.

Jak to? Zawoła Ksiądz Arcypasterz - pożyczkę spłacać na „Przedświt”, więc co to ma do drukarni? Zaraz wyjaśnię. Ale przedtem jeszcze przypomnę Księdzu Arcypasterzowi tę rozmowę naszą coś przed pół rokiem prowadzoną, w której mi Ksiądz Arcybiskup opowiadał, że na licytacji kupuje jakiś dom, który przy pierwszej licytacji kupić się nie udało, ale który ma być kupiony później i że w tym domu mają być pomieszczone różne stowarzyszenia, a i drukarnia. Na ten dom Ksiądz Arcybiskup miał przeznaczyć coś około 70 tysięcy, które za pozwoleniem namiestnictwa z jakichś funduszów spłacać się miały. Jeśli się nie mylę, z tych 30 tysięcy miała pochłonąć drukarnia. Otóż jak z jednej strony Ksiądz Arcybiskup wobec swych planów przyszłości prawie musi mieć drukarnię - tak z drugiej strony Ksiądz Arcybiskup absolutnie jej mieć nie może, czy to pod swoją firmą, czy to w jakikolwiek sposób złączoną ze swą osobą. A to z tej prostej przyczyny, że by się bardzo łatwo to stać mogło z Księdzem Arcypasterzem, co z biskupem Kopem $^{131}$. Któryś z jego pełnomocników źle płacił robotnikom, a w parlamencie wywleczono, że to on. Otóż niech kierownik drukarni oddali jakiego zecera to wobec tego, że ci zecerzy tkwią w gnieździe socjalistów i mają ciągłe koneksje, jakże łatwo z takiego drobiazgu wniesie p[an] Daszyński ${ }^{132}$ interpelacje o uciskach Arcybiskupa łacińskiego. Albo np. niech namiestnictwo da jakie roboty drukarni, a już zaraz powiedzą, że to ono wspiera Arcybiskupa łac. itp. $Z$ tej już przyczyny jezuici nie założyli drukarni, tym więcej na to uważać musi Ksiądz Arcybiskup.

Jakie więc stąd jest wyjście? Oto to, że Ksiądz Arcybiskup ma drukarnię, ale nie bezpośrednio tylko pośrednio przez pismo. „Przedświt” zakłada drukarnię, ona jest jego przedsiębiorstwem, a że przedmiot jest w ręku Księdza Arcybiskupa, więc Ksiądz Arcybiskup przez pismo ma drukarnię. Więc zamiast dawać na drukarnię wprost, Ksiądz Arcypasterz daje na nią pośrednio, a dlatego pośrednio, by w ten sposób umożliwić powstanie drukarni, czyli iż danie „Przedświtowi” 30 tysięcy pożyczki może być uważane za środek do celu, to jest do powstania drukarni.

131 Właściwie: Kopp Georg (1837-1914), święcenia kapłańskie w 1862 r. w Hildesheim, 1881-1887 biskup Fuldy, od 1884 r. członek pruskiej Rady Państwa, od 1887 r. członek Izby Panów, 1887-1914 biskup Wrocławia, w 1893 r. mianowany kardynałem, 1886-1887 przewodniczący komisji regulującej relacje Kościół-państwo, od 1900 r. pełnił funkcję przewodniczącego Konferencji Episkopatu Niemiec. Dążył do zerwania łączności Górnego Śląska z całością ziem polskich. K. Engelbert, Kopp Georg, w: LThK, Bd. 6, herausg. von J. Höfer, K. Rahner, Freiburg im Br. 1961, kol. 537-538; J. Pater, Z dziejów wrocławskiego Kościoła, Wrocław 1997, s. 83-85; J. Mandziuk, Postacie Kościoła katolickiego na Ślasku, Warszawa 2016, s. 626-630.

132 Daszyński Ignacy (1866-1936), współzałożyciel i przywódca PPSD, 1897-1917 poseł do parlamentu austriackiego, 7 XI $1918 \mathrm{r}$. proklamował w Lublinie powstanie rządu złożonego z socjalistów i radykalnych ludowców, którego został premierem i ministrem spraw zagranicznych. Był jednym z przywódców PPS, 1920-1921 wicepremier, 1919-1930 poseł do Sejmu, 1922-1927 wicemarszałek, 1928-1930 marszałek Sejmu. Był jednym z czołowych opozycjonistów obozu sanacyjnego w Polsce. J. Gołębiowski, Daszyński Ignacy Ewaryst, w: Kto byt kim w Drugiej Rzeczypospolitej, red. J. Majchrowski, Warszawa 1994, s. 36. 
Z wrażenia zaś, jakie wyniosłem z konferencji z Chromińskim ${ }^{133}$ wreszcie sądząc po udziałach, które clausi $^{134}$ już są przyobiecane, uważam założenie drukarni w niedługim czasie przy „Przedświcie” za rzecz pewną. Taka zaś drukarnia może ogromne przynosić zyski, bo przez stosunki nasze możemy sobie wyrobić robotę $w$ namiestnictwie, wydziale krajowym, etc., etc. Swoją drogą nie można przeoczać szczegółu, że drukarnia taka będzie na udziały. Chcąc mieć drukarnię bez obcych udziałów musiałoby się pożyczkę mieć większą (udział obcych zawsze ich do wpływu pewnego przypuszcza).

Zostaje mi na końcu jeszcze jedna rzecz do poruszenia. Wahałem się, czy pisać o niej, ale w końcu napiszę gdyż wiem, że mnie Ksiądz Arcypasterz nie wyrozumie źle. Powodem, dla którego piszę jest to, iż usłyszałem z ust Księdza Arcybiskupa powiedzenie, że wydając pieniądze liczyć się musi ze sumieniem i spowiednikiem, i że sumienie by nie pozwoliło może wydać tak wiele. Pomijam już ten wzgląd, który właściwie nie moją jest rzeczą poddawać, iż skoro raz się sobie powiedziało, że dziennik katolicki koniecznością jest i że bankrutować nie może, to się kilka tysięcy i kilkanaście nawet więcej lub mniej zaryzykować musi, gdyż połowiczność nic nie zyska. Ja tu chcę zwrócić na co innego uwagę. Oto przypuszczam, że „Przedświt” z dniem ostatniego grudnia się zamyka, przypuśćmy, że się nikomu w spadku prenumeratorów nie zostawia i że pismo wykazuje deficytu 20 tysięcy. Ponieważ nie jest wyświeconym między nami dwoma, kto właściwie ma to zapłacić, więc przypuśćmy znowu, że tę sprawę oddajemy pod sąd polubowny wzywając np. Ks. Ks. Wałęgę, Szeptyckiego i Puzynę. Nic nie kosztuje takie przypuszczenie, więc snuć będę wątek dalej. Przedkłada się, że cała sprawa między mną a Księdzem Arcypasterzem. Kwestia jest o to, kto z nas dwu ma zapłacić te 20 tysięcy? Otóż Księże Arcypasterzu sądzę, że nie mnie by kazano. Dlaczego? Bo moja cała rola w „Przedświcie” była tylko rolą plenipotenta. I nie mogła być inna, bo absolutnie nie miałem pieniędzy i nie mam, by brać na siebie albo spółkę, albo jakiekolwiek jakie do wydawnictwa pismo jest przywiązane. Prawdą jest, że opierając się nie na swoim, ale na Kułakowskiego ${ }^{135}$ powiedzeniu mówiłem Księdzu Arcybiskupowi, że 15 tysięcy na 1-szy rok wystarczy. Ale zapewniłem tak jakby np. zapewniał Puchalski ${ }^{136}$, że na osuszenie łąk potrzeba tysięcy 15 , a tymczasem się pokaże, że potrzeba 30 to samo przez się rozumie, że za to nie Puchalski, ale Ksiądz Arcybiskup zapłaci. Zresztą Ksiądz Arcybiskup nie polegał na moim tylko twierdzeniu, ale sprowadził i Pilata, który też mówił - więc odpowiedzialność między nas dwu w najgorszym razie byłaby podzielona ${ }^{g}$.

${ }^{133}$ Postać niezidentyfikowana.

134 Łac.: postanowić, uchwalić, zamknąć.

135 Postać niezidentyfikowana.

136 Puchalski Wawrzyniec (1842-1920), święcenia kapłańskie w 1867 r. w Przemyślu, wikariusz w Sanoku i Samborze, 1874-1875 proboszcz par. Wysoka k. Łańcuta, 1875-1893 proboszcz par. Łąka, 1893-1920 proboszcz par. Wyżniany - archidiec. lwowska, od 1901 r. zarządca dóbr stołowych arcybiskupstwa lwowskiego, szambelan papieski, autor zbiorów kazań i czytań różańcowych dla ludu oraz kilku monografii parafii. Kościót rzymskokatolicki i Polacy w Małopolsce Wschodniej podczas wojny ukraińsko-polskiej 1918-1919. Źródta, t. 1, opracowanie, wstęp, przypisy, indeksy i wybór fotografii J. Wołczański, Lwów-Kraków 2012, s. 591.

g Na marginesie dopisek piórem ręką abp. Bilczewskiego: „Właśnie wobec Pilata, Abrahama, Dembowskiego zaręczał Ks. Teod[orowicz], że kosztorys dokładny, że bierze za kosztorys odpowiedzialność". 
Lecz czyżby aż sądu polubownego było potrzeba? Znam złote i czyste ręce Księdza Arcypasterza i wiem, że by powiedział nawet w tym wypadku, gdybym ja, jako spólnik $^{\mathrm{h}}$ występywał ${ }^{\mathrm{i}}$, a nie jako plenipotent, jest jak jest, ale ten człowiek uwolnił mnie od Zawadzkiego i od „Ruchu Katolickiego”, co samo jest warte 20 tysięcy, własnym nazwiskiem osłaniał mnie, naraził się dla mnie wszystkim, więc nie godzi się by jeszcze szedł w długi z których by w jego stosunkach wybrnąć nie mógł przez całe życie!, a skoro tylko plenipotentem byłem, to i ta pewno racja nie byłaby potrzebną, bo secundum iusticiam $^{137}$ należałoby się to. Straciło się, to się straciło jak na tylu się traci przedsiębiorstwach, przepadło, a nawet w tym najskrajniejszym wypadku zyskało się usunięcie Zawadzkiego, co warte tyleż najmniej, co strata. Wszystko to jest gadanina przypuszczeń, która wobec tego, że namiestnik „Przedświt” by wykupił, nie ma realnej podstawy, ale gdy już o sumieniu mowa, to nie było od rzeczy tę stronę poruszyć.

No, ale już czas najwyższy skończyć. Patrząc na zabazgrany 8 arkusz kończę co rychlej wołając "dixi et salvavi animam meam" ${ }^{138}$, przepraszam za takie nadużycie cierpliwości Waszej Arcypasterskiej Mości i łączę wyrazy najgłębszej i najoddańszej czci

Ks. Teodorowicz

Putiatyńce, d[nia] 3/XII [1]901

Jeszcze jedno. Poddaję to Księdzu Arcypasterzowi do rozwagi prosząc, by ze względu na moje poufne rzeczy, list nie był innym czytany. Dobrze by było, by Ksiądz Arcybiskup wybrał na czytanie swobodniejszą chwilę. Zestawiwszy wszystko ani doradzam, ani namawiam Księdza Arcybiskupa. Czas decyzji zostawiam Księdzu Arcybiskupowi, ale zastrzegam się, że nie może być długi. Ja muszę przed konsekracją porządek zrobić i nie mogę dopuścić dla siebie i dla swego stanowiska żadnej niejasności, żadnego półcienia.

Stosunek nasz wzajemny na wypadek zgodzenia się na rzecz Księdza Arcybiskupa musiałby być osobno skrystalizowany.

\section{Dokument 21}

Najczcigodniejszy K[sięże] Arcybiskupie!

Jakkolwiek zdziwiło mnie, że w kwestiach czysto redakcyjnych Ksiądz Arcypasterz zwraca się do mnie, to jednak by dogodzić Księdzu Arcypasterzowi i własną ciekawość zaspokoić zwróciłem się do redakcji o wyjaśnienie. Odpowiedź otrzymałem, iż wiadomość o składkach wypisano z niemieckich bukowińskich gazet, które na liście dających podały nazwisko Księdza Arcypasterza. Redakcja twierdzi, że takie rzeczy przypuszcza, że z góry są najpewniejsze.

h Zapis zgodny z oryginałem; poprawnie powinno być: wspólnik.

Zapis zgodny z oryginałem; poprawnie powinno być: występował.

137 Łac.: ze sprawiedliwości.

138 Łac.: powiedziałem i uspokoiłem swoje sumienie.

a List pisany jest na podwójnej, nieliniowanej kartce formatu kieszonkowego. Posiada znak wodny przedstawiający napis: „Sar Mill Hand - Made” oraz sześcioramienną gwiazdę, wewnątrz której umieszczona jest data: „1866”. Brak miejsca wystawienia dokumentu i datacji. 
Co do kroniki, to znowu robiono zastrzeżenia, że kroniki humorystyczne nie są wyrazem opinii redakcji i że za takie też je nie biorą, czego dowodem taki Potoczek ${ }^{139}$, który naciągnięty w kronice ani myślał się pogniewać i „Przedświt” prenumeruje. Relata refero ${ }^{140}$ przedkładam Księdzu Arcypasterzowi zdanie redakcji, a gdyby Ksiądz Arcypasterz miał co do zarzucenia, proszę bardzo do nich wprost się zwrócić, względnie do mego brata, który dziś za pismo odpowiada. W ogóle gdyby na przyszłość chodziło Księdzu Arcypasterzowi o jakie wyjaśnienia proszę uprzejmie żądać takowego wprost od redaktora, który je ma obowiązek dać, a i da bezpośrednie i najdokładniejsze.

Łączę przy tej sposobności wyrazy najgłębszej i najoddańszej czci

Ks. Teodorowicz

\section{Dokument 22}

Ekscelencjo! ${ }^{a}$

Pan Tatarczuch ${ }^{141}$ ma prośbę do Ekscelencji, by mianowicie wyjednał Ksiądz Arcybiskup order papieski dla jednego z lekarzy pracujących z wielkim oddaniem się i bezinteresownością w poliklinice. Pan Tatarczuch znany mi jest osobiście zarówno z szlachetności charakteru jak i przekonań religijnych, przeto na jego informacji może Ekscelencja śmiało polegać, a zasługuje też na to, by prośbę jego uwzględnić.

Łączę prawdziwie oddane wyrazy czci i szacunku

Ks. J[ózef] Teodorowicz

wtorek, d[nia] 9/XII [1]901

\section{Dokument 23}

\section{Najczcigodniejszy Księże Arcypasterzu! ${ }^{a}$}

Dziś znowu zaalarmuję Księdza Arcybiskupa wieścią o „Ruchu”. Zawadzki zdefraudował w tym roku w lipcu na „Ruch” 6 tysięcy niejakiej pani Bauerowej ${ }^{142}$ wdowy, która mu dała swoją książeczkę kasy oszczędności, by jej wyjął 100 fl[orenów] na jej cele. On zaś książeczkę wziął i wyjmował aż do 6 tysięcy. Jest więc teraz w przededniu procesu karnego. Skandal więc nowy grozi katolikom nieszczęśliwym, których redaktor defrauduje

139 Postać niezidentyfikowana.

140 Łac.: zdaję sprawę z tego, co sam słyszałem.

a Powyżej obcą ręką, niebieską kredką nazwisko: „Teodorowicz”. List pisany jest na nieliniowanej, podwójnie złożonej kartce formatu kieszonkowego. Znak wodny przedstawia imitację słojów drzewnych. Brak miejsca wystawienia dokumentu.

${ }^{141}$ Tatarczuch Władysław - lekarz dermatolog, pracownik Polikliniki Powszechnej we Lwowie przy ul. Sienkiewicza 1/17 i Lindego 1/5.

a Powyżej obcą ręką, niebieską kredką widnieje nazwisko: „Teodorowicz”. List pisany jest na podwójnej, kratkowanej kartce formatu zeszytowego bez znaku wodnego.

142 Postać niezidentyfikowana. 
pieniądze. Z drugiej strony widać, że nóż ma on do szyi przyłożony, że pieniędzy nie miał i że liczył na przyszłą nową kombinację co do „Ruchu”. Co robić na to? Był u mnie adwokat Schürr i drugi adwokat w tej sprawie. Mówią, że 3-ma tysiącami złotych może by się dało wdowę jako uspokoić. Dla interesów „Przedświtu” jest to sprawa kompletnie obojętna, ale jeśli by Ksiądz Arcybiskup chciał co dla zażegnania skandalu co zrobić, to proszę albo mnie powiadomić, albo do Schürra się odnieść.

O „Przedświcie” nic nie pisałem dotąd czekając raczej na opinię o piśmie. Ogólne wrażenie pisma przeszło moje oczekiwania. Jednym słowem mimo krytyk pomniejszych całość przyjętą została dobrze i pismo ma przyszłość przed sobą, byle tylko ciężkie czasy przetrzymać. Głowa mi pęka dla nawału różnych prac i trudności. Ale Bóg widocznie dopomaga. Nie można od razu uwzględnić wszystkiego, powoli dopiero wyrabiać się będziemy. Prenumeratorów do dziś już mamy około 700, co jest na początek.

Łączę wyrazy czci najgłębszej i oddania

Ks. Teodorowicz

Lwów, dnia 27/XII [1]901

\section{Dokument 24}

Wasza Arcybiskupia Mość! ${ }^{a}$

Pozwoli Wasza Arcybiskupia Mość, że z okazji wyszczególnienia i nominacji Waszej Arcybiskupiej Mości Tajnym Radcą, prześlę życzenia serdeczne ad multos annos ${ }^{143}$.

† Józef Teodorowicz

Lwów, dnia 6/I |1|902

\section{Dokument 25}

\section{Wasza Arcybiskupia Mość! ${ }^{\mathrm{a}}$}

Wobec tego, iż z wczorajszego listu wnoszę o gotowości Waszej Arcybiskupiej Mości do załatwienia całej sprawy w drodze pokojowej, nie uchylam się, ale owszem najchętniej się godzę i na odpowiedź na stawiane zarzuty w liście wczorajszym i na rozmówienie się u Naj[czcigodniejszego] Ks[iędza] Ar[cybiskupa] Webera. Proponuję tylko przedtem dopełnienie formalnej strony przez wystawienie mi przez Waszą Arcybiskupią Mość oświadczenia (najlepiej we formie listu). Ja właśnie dlatego po odebraniu pieniędzy w sobotę wstrzymywałem się z listem, gdyż mi mówił Ks. Kapelan ${ }^{144}$, że Wasza Arcybiskupia Mość list nadeśle jutro, tj. w niedzielę. Sądziłem tedy, że to będzie rodzaj oświadczenia

a Powyżej obcą ręką napisano niebieską kredką nazwisko: „Teodorowicz”. List pisany jest na podwójnej, kratkowanej kartce formatu zeszytowego. Znak wodny przedstawia bogato zdobiony monogram i napis: "Original Neusiedl Bank Post".

${ }^{143}$ Łaciński odpowiednik polskich życzeń „stu lat”

a Powyżej niebieską kredką, obcą ręką napisane jest nazwisko: „Teodorowicz” i ołówkiem nazwisko: „Komar”. List pisany jest na podwójnej, nieliniowanej kartce formatu zeszytowego.

${ }^{144}$ Kapelanem i sekretarzem abp. J. Bilczewskiego w l. 1901-1905 był ks. dr Albin Warszylewicz (1872-1941). 
danego mi tak samo ze strony Waszej Arcybiskupiej Mości, jak je znowu dałem od siebie. Przed daniem podobnego oświadczenia nie uważałem sprawę za załatwioną formalnie, czego najlepszym dowodem jest to, że pieniądze nietknięte zachowałem.

Co do formy tego oświadczenia nie żądam żadnych już szczegółów, poprzestanę na najbardziej ogólnikowej, wszak z tym się nigdzie nie będę popisywał, idzie tylko o to, bym takie absolutorium i ja miał w ręku, jak je ma ze Swej strony Wasza Arcybiskupia Mość ode mnie. Załączam do tego listu formularz, oczywiście nie myśląc go narzucać Waszej Arcybiskupiej Mości, ale dla ułatwienia Mu zadania i dla pokazania, o co mi właściwie chodzi.

Przyczyna zaś, dla której proszę o załatwienie tej sprawy formalnej przed rozmówieniem się naszym jest podwójna: raz dlatego, że daleko swobodniej można omawiać zarzuty wzajemne po zupełnym załatwieniu formalnym, a po wtóre, iż mi zależy na pośpiechu, by co rychlej nuncjaturę uwiadomić, iż sprawa została zupełnie załatwioną.

Łączę wyraz szacunku głębokiego

† Józef Teodorowicz

Lwów, sobota 16/I [1]902

\section{Dokument 26}

Najczcigodniejszy Księże Arcypasterzu! ${ }^{\mathrm{a}}$

Na takie wezwanie to choćby z łóżkiem się idzie, a tym bardziej bez łóżka. Mogę tylko dziękować opatrzności, że dała Pasterza, który tak rozumie potrzeby czasu i tak w nie wchodzi. Myślałem, że Ksiądz Arcybiskup na moje gadulstwo pogniewa [się], więc by słów nie tracić przyjdę.

Ucałowuję ręce i zostaję z czcią najgłębszą, oddany

Ks. Teodorowicz

\section{Dokument 27}

Najczcigodniejszy Księże Arcypasterzu! ${ }^{\mathrm{a}}$

„Przedświt” i na rekolekcjach ${ }^{145}$ spokoju mi nie daje. Oto z namiestnikiem wybrnie się w ten sposób, że się da dziś artykuł ogólny o rozłamie partii krakowskiej, przy czym rozbiera się stanowisko wobec namiestnika tejże partii. Tak więc i wilk syty, i koza cała. Nie ma słówka o popieraniu go, a jednak ubocznie jest poparcie. Nawiasem mówiąc namiestnik ogromnie kontent $\mathrm{z}$ „Przedświtu”, mówił mi to dziś i dodawał, że „Przedświt" wyszedł z lat chłopięcych, że ma wyborne artykuły, że jego stanowisko wobec

a Powyżej niebieską kredką, obcą ręką napisane zostało nazwisko: „Teodorowicz” i ołówkiem data: „1902”. List pisany jest na podwójnej kartce formatu kieszonkowego. Znak wodny przedstawia zdobiony napis: „Victoria Note Paper”. Brak miejsca wystawienia dokumentu i datacji.

a Powyżej niebieską kredką, obcą ręką napis: „Teodorowicz 1902”. List pisany jest na podwójnej, nieliniowanej kartce formatu kieszonkowego. Brak miejsca wystawienia dokumentu.

${ }^{145}$ Abp J. Teodorowicz odbywał wówczas rekolekcje przed przyjęciem sakry biskupiej. Prekonizacja na arcybiskupstwo lwowskie ob. ormiańskokatolickiego miała miejsce 16 XII 1901 r., a konsekracja 2 II 1902 r. 
rozruchów jest bardzo poprawne i że ma informacje o zdolnościach obecnej redakcji. Anim go o to pytał, ni mowę o tym rozpoczynał, więc zrozumie Ksiądz Arcybiskup, że mię ta elokwencja w zdumienie wprawiła.

Najoddańsze wyrazy łączę

Ks. Teodorowicz

30/I [1]902

\section{Dokument 28}

Najczcigodniejszy Księże Arcypasterzu! ${ }^{a}$

Przepraszam, że tak spóźniam się z odpowiedzią, lecz cały ranek miałem wydarty. List oddałem bratu, a zarzuty podnoszone przeciw niemu zostawiam bez odpowiedzi, by nie nadawać sobie więcej pozorów, że chcę go na redaktorstwie podtrzymać. Zresztą jest jeden zarzut, którego zrozumieć nie mogę, ten mianowicie, gdzie mu Ksiądz Arcypasterz podsuwa złą intencję; powtarzam, że zarzutu nie rozumiem, gdyż takowy dosłownie wzięty byłby za ciężki nie tylko dla niego, ale i dla mnie.

Co do zarzutów, co do „Przedświtu” nie mam doprawdy czasu odpowiadać, bo dużo by o tym mówić. Zresztą proszę mi tego nie brać za złe, gdy powiem, iż już nie umiem odpowiadać. Wskazywałem Księdzu Arcypasterzowi, na mnogie zasadnicze artykuły, którymi dziś bezwarunkowo „Przedświt” bije wszystkie inne pisma z wyjątkiem może jednego „Czasu”; wskazywałem na najżyczliwsze krytyki i zajęcie za ogółem „Przedświtem". Wskazuje zresztą sama prenumerata jak na rok pierwszy niezwykle wysoka, a ciągle rosnąca. Niestety, to wszystko nie zadowoliło Księdza Arcypasterza, nie pamiętam, by choć raz, choć w drobnostce co mi przyznał Ksiądz Arcypasterz, natomiast uważam jaką uwagę przywiązuje Ksiądz Arcypasterz do zdania tych ludzi, którzy spełniają rolę najłatwiejszą krytyków; w ogóle słyszę ciągłe zarzuty ogólnikowe, że „Przedświt” szkodzi, obniża katolicyzm i Osobę Księdza Arcypasterza, etc. Nie czynię z tego zarzutu Księdzu Arcypasterzowi, bo wiem, że Ksiądz Arcypasterz Sam nie ma czasu czytać, natomiast pismo niezależne zbyt wielu ludziom pokój psuje, więc szczują. Za wiele by o tym zresztą mówić i za długo. Znam całą sieć zarzuconą przez ludzi zręcznych na Osobę Księdza Arcypasterza, by Go do „Przedświtu” za wielką cenę zrazić. Jestem już zanadto zrażony bym wobec tego próbował obrony, w możliwość której przestałem już wierzyć, więc z niej kapituluję.

Zdawało mi się, że między liniami listu Księdza Arcypasterza były jeszcze inne kwestie, ale tak się samego dotknięcia ich boję myślą samą, iż jak przed pokusą, przed podejrzeniem się bronię, że mi Ksiądz Arcypasterz chciał coś dać do poznania, co we własnym naszym interesie nawet wymówionym by być nie powinno. Więc mówię sobie, że to przewidzenie moje i drażliwość moja, a nie co innego.

a List pisany jest na podwójnej, nieliniowanej kartce formatu zeszytowego. Papier nie posiada znaku wodnego. Brak miejsca wystawienia dokumentu i datacji. 
Porusza Ksiądz Arcypasterz w liście jeszcze kwestie pomniejsze i interesa, którymi jednak absolutnie dziś się zająć nie mogę, ze względu na nawalne zajęcia, które mi absolutnie nie pozwalają na nic poza sprawą, jaką mam dzisiaj w przygotowaniu się do 2 lutego ${ }^{146}$.

Racz przyjąć Wasza Arcypasterska Mość najoddańsze i najgłębsze wyrazy mej czci i szacunku

Ks. Teodorowicz

\section{Dokument 29}

Wasza Ekscelencjo! ${ }^{\text {a }}$

Notatka „Przedświtu” nic nie orzeka o tym, czy Ekscelencja należy, czy nie należy do pisma, tylko oświadczenie zawiera, że nieprawdą jest, jakoby oświadczenie podobne od Ekscelencji wyszło. Niepotrzebnym był tylko przydatek redakcji „jesteśmy upoważnieni", ale to może stąd pochodziło, iż interpelowany byłem przez kapłana pewnego i osobę bliską sfer „Przedświtu” wyrażających zdziwienie, że w rzekomo w takiej właśnie chwili Wasza Ekscelencja wypiera się pisma. Otóż odpowiedziałem, że Ekscelencja absolutnie takiego oświadczenia nie dawał i sam przysłał z tym do mnie Swego kapelana. Jeszcze zresztą dziś pomówię z redaktorem.

Co do uwagi Waszej Ekscelencji o mej osobie to zauważę, że rozróżnić należy między bezpośrednią, a pośrednią ingerencją Biskupa w piśmie. Bezpośrednią, gdzie biskup jest jednym z członków redakcji, jest niezawodnie dla niego szkodliwą, a że mnie wciąż o to pomawiają, więc wypieram się wszelkimi sposobami tego. Pośrednie atoli, to znaczy, że wiedzą, że organ katolicki w szczegółach samoistny, ale w całym kierunku ma czucie z episkopatem i jednym biskupem - to tylko świadczyć może o moralnej sile biskupa, co za pismem z dala stoi i z nim pewne ma czucie. Tak przynajmniej się zdaje.

Łączę przy tym dla Ekscelencji wyrazy najgłębszego szacunku, sługa oddany

† Józef Teodorowicz

\section{Dokument 30}

Najczcigodniejszy Księże Arcypasterzu! ${ }^{\text {a }}$

Z całego serca dziękuję Waszej Arcypasterskiej Mości za list ostatni, z którego wieje tyle szczerości serca, że jestem tym ujęty i za to wdzięczny. W sprawie finansowej widzę,

146 Dzień sakry biskupiej autora listu.

a List pisany jest na podwójnej, nieliniowanej kartce formatu kieszonkowego. Znak wodny przedstawia napis: „High Life Ivory Paper”. Brak miejsca wystawienia dokumentu i datacji.

a Powyżej ołówkiem, obcą ręką napisane nazwisko: „Teodorowicz” i data: „1902”. Brak miejsca wystawienia dokumentu i datacji. List pisany jest na dwóch podwójnych, nieliniowanych kartkach formatu zeszytowego. Kartki posiadają znak wodny w postaci napisu: „Bombay Paper” i litery „F”, umieszczonej poniżej wewnątrz sześcioramiennej gwiazdy. 
że w konturach ogólnych będzie możliwy projekt Księdza Arcybiskupa, ale konkretne

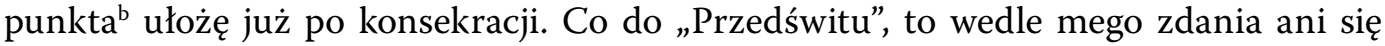
obaj nie różnimy, ani mamy powód do czarnych myśli. Powtarzam, że się nie różnimy, bo tylko z innej strony wychodzimy, ale w jednej zbieramy się drodze. I tak np. ja biorę dziennik jak obraz. I to obraz na deskach teatralnych. Dobry jest, skoro najogólniejsze rzuty są śmiałe, skoro z oddalenia jest skończony. $Z$ bliska daruję mu niejedno, ale tak jak się darowuje brodawki na ładnej twarzy. Lepiej by ich nie było, ale skoro są to cóż robić? Lepsza kształtna twarz z brodawką, niż niekształtna bez nich. Lepszy dziennik ze śmiałymi zasadniczymi rzutami a z usterkami, niż wymuskany, skończony bez nich. Ksiądz Arcypasterz z pewnością sądzi tak samo, tylko, że Ksiądz Arcybiskup nie zna technicznego aparatu dziennika i dlatego nie osądza należycie tych rzutów, a oczywiście widzi rażące brodawki. Np. weźmy 2 ostatnie kroniki. Kronikę taką można albo brać serio, albo brać tak jak się bierze np. dowcipy Księdza Biskupa Wałęgi. Coś serio, coś żartem. Na wszelki wypadek nie byłem kontent z kroniki ostatniej i przedostatniej. Tylko, że inaczej osądziłem redakcję gdyż znałem zakulisową maszynerię. I tak kronikę przedostatnią posyłał brat komuś do skorygowania, który był bardzo do tego kompetentny i ten to skreślił cokolwiek, a fijołkac ${ }^{\mathrm{c}}$ zostawił. W ostatniej zaś znów zaszło co innego. Bo przysłane w sobotę miało być wyjętą z maszyny, ale cóż kiedy 2 artykuły, które miały być napisane spaliły na panewce, więc zadowolono się najkonieczniejszymi poprawkami. Prawda, że trzeba dążyć do tego, aby i usterki były wykluczone, ale to możliwe dopiero z tą chwilą, gdy redaktor cały numer czyta od deski do deski. To zaś jest dopiero wtedy możliwe, gdy nie ma w ręku administracji, bo te 2 maszyny razem uniemożliwiają to. Więc przez czas jakiś takie kuksy są nieuniknione:

a) Dlatego, że jak mówię redaktor musi 2 sroki za ogon trzymać i nie czyta całego numeru.

b) Dlatego, że nie ma dorady księdza, a zatem świecki nie opanuje sfery kościelnej, której nie zna.

c) Bo każde pismo w pierwszym roku dopiero się kształtuje i musi kuksy mieć, dziś ich przecie nieskończenie mniej niż dawniej.

d) Bo charakter „Przedświtu” jest być kamuflażem Kościoła, więc większa żywość i ruchliwość, i nawet tu i tam o coś zawadzi, gdzie drwa rąbią tam trzaski lecą.

e) Bo pismo w pierwszym roku musi dbać o captandam benevolentiam ${ }^{147}$ audytorium, które na rzeczy się merytorycznie nie zna, by można poznać jego charakter. Dziś przecie zupełnie straciło to rzucanie się na innych. Już teraz bardzo poważnie i raczej podnosi osoby, jak na nie się rzuca.

f) Bo redaktor wskutek braku kontaktu z Księdzem Arcypasterzem jest doprawdy zbałamucony. I tak np. raz mu wołam: bój się Boga, czemuś nie pomieścił korespondencji z Tarnowa księży? Więc on na drugi raz sądząc, że wolą jest by każda korespondencja szła pakuje np. taką, jak starosta z Mościsk.

\footnotetext{
b Zgodne z oryginałem; poprawnie powinno być; punkty.

Zgodne z oryginałem; w znaczeniu: błąd, usterkę.

147 Łac.: zyskanie przychylności.
} 
g) Ja się zawsze dziwię, że tak mało fałszywych kroków w drobiazgach. Bo przecie proszę zważyć, że dziś Madurowicz wyjechał, a przy tym brat od miesiąca i w kłopotach pieniężnych, a i przy konsekracji zajęty, więc wszystko cudem Bożym idzie, a „Przedświt" przecie jest tak [... $]^{\mathrm{d}}$ i przeze mnie, i przez Księdza Arcybiskupa, że gdyby tak chcieć „Czas” krakowski [... $]^{\mathrm{e}}$, który ma 3 razy współpracowników i fundusze, nie wytrzymałby krytyki.

Teraz jeszcze powiada Ksiądz Arcypasterz, że osoby mnie życzliwe mówią, że brat niedobrze redaguje. Ale na czym to opierają? „Przedświt” idzie w górę i to nie dlatego, że katolicy dla zasady go popierają, bo w takim razie dlaczego „Ruch” z nazwą katolicką spadał? Idzie więc znak, że redaktor dobrze siedzi w duszy swych czytelników. Po wtóre, opieram mój poprzedni sąd o jego wolności na tym, że widzę jego ciągłe wyrabianie się. Wszakże dziennikarstwo jest sztuką, której się uczyć potrzeba jak każdej innej. A on przecie od kilku miesięcy jak wszedł do redakcji. Wziąłem go z konieczności po niezdarności Madurowicza i Kuśmińskiego wprost mimo jego woli. W tym krótkim czasie postąpił ogromnie i wyrobił się w oczach. Po trzecie, ma zdrowy rozsądek, co jest niezbędnym warunkiem redaktora. Np. proszę zliczyć, ile Koneczny przez brak zdrowego zmysłu głupstw narobił wtrącając w jednym tygodniu i Kozłowskiego, i rusinów ${ }^{\mathrm{f}}$, i chłopów z Gawłuszowic ${ }^{148}$, i „Kalendarz” nieszczęśliwy. Po czwarte, ma inicjatywę, np. sobotni numer. On dostał o rozruchach artykuł profesora jednego, w ostatniej chwili wycofał z drukarni. Kazał napisać drugi. Poliński ${ }^{149}$ napisał, ale słabo, znowu odrzucił i poddał myśli i duch artykułu Kuśmińskiemu. I to było dobre. Całe stanowisko strategiczne w rozruchach „Przedświtu” było dobre i zdrowe, a ręczę, że taki Koneczny jednym artykułem byłby już zdyskredytował „Przedświt”. Potem sądziłem brata, który na drobniejsze rzeczy jak mówię i czasu już nie miał. Piszę to dlatego, by Ksiądz Arcybiskup widział, że choć o bracie nie sądziłem za pospiesznie, zresztą mówię to obecnie po jego rezygnacji, nie chciałem zaś wywlekać przedtem, by uniknąć posądzenia, że mi zależy na jego stanowisku ze względów rodzinnych.

Tyle na dziś, bo już masa zajęć mnie przygniata. Ja będę jeszcze z osobną prośbą u Księdza Arcybiskupa, aby wyświadczyć chciał tę łaskę i przyjął Biskupów u siebie. O udziale w konsekracji osobno nie wspominam, bo umówiliśmy tę rzecz we Wiedniu.

Łączę najserdeczniejsze i najoddańsze wyrazy

Ks. Teodorowicz

Bravissimo! $!^{150}$ I Ksiądz Arcypasterz wchodzi w szranki dziennikarzy! Myślę o artykule o $[\ldots]^{g}$ Nie dałem go pomieścić wszakże dziś, gdyż chciałem jeszcze pomówić o tym z Księdzem Arcypasterzem ${ }^{\mathrm{h}}$.

d Tekst nieczytelny.

Tekst nieczytelny.

Zgodne z oryginałem; poprawnie powinno być: Rusinów.

148 Gawłuszowice - wieś na Podkarpaciu na Rzeszowszczyźnie.

149 Osoba niezidentyfikowana.

150 Wł.: doskonale, wspaniale.

$g$ Tekst nieczytelny.

h Poniżej nota ręką abp. Bilczewskiego: „Nie porozumiał się - rzucił do kosza. Bilczewski”. 


\section{Dokument 31}

\section{Najczcigodniejszy Księże Arcypasterzu! ${ }^{\mathrm{a}}$}

Dziękuję za list łaskawy. Będę w sprawie „Przedświtu”, jak tylko ukończę cały plan. Może nawet dziś jeszcze. Co do odezwy, to wczoraj układał numer nie brat, ale Madurowicz, gdyż brat zbyt niestety zajęty lepieniem dziur pieniężnych poprzestaje na ogólnym tylko kierownictwie. Na obronę Madurowicza to jednak powiem, że ze względów technicznych nie mógł zrobić inaczej. Co bowiem może sobie pozwolić pismo w dużym formacie, które na tej stronie samej obok odezwy naczelnej ma jeszcze miejsce na inne artykuły, to w normalnych warunkach jest złamaniem kardynalnego prawidła techniki dla pisma w małym formacie, które choć tę odezwę dać na czele musi całą pierwszą szpaltę zadrukować, bez możności pomieszczenia innego artykułu. Tak samo co do podpisów daje się zawsze tylko wybitniejsze. „Przegląd”, który zawsze kontent, gdy może czym szpalty zadrukować, nie jest miarodajny.

Oczywiście zmienia się wszystko, gdy Ksiądz Arcybiskup sobie osobno tego życzy. Ale w takim razie musi być redakcja naprzód o tym powiadomioną. Więc piszę to, by na przyszłość porozumienie ułatwić. Odezwa wedle życzenia Księdza Arcybiskupa pójdzie z podpisami, ale dopiero jutro, gdyż dziś już za późno do redakcji przekazałem, a jutro i tak wychodzi dodatek i sobota, więc i lepiej nawet będzie.

Tymczasem najoddańsze łączę wyrazy dziękując za pamięć o zdrowie, które jest lepsze. Byle z „Przedświtem” załatwić, bo wszystko czeka i listy moje pasterskie niegotowe i całe przygotowanie do obchodu ${ }^{151}$

Najoddańszy

Ks. Teodorowicz

\section{Dokument 32}

Najczcigodniejszy Księże Arcybiskupie!

A więc usuwa się Ksiądz Arcybiskup od wszystkiego i odmawia swego współudziału w likwidacji pisma. Zostaję sam i tu u końca opuszczony, a w całej tej sprawie tak odepchnięty, tak po prostu - proszę darować wyrażenie - kopnięty!

Bo czy mogę inaczej czuć w mej duszy, zwłaszcza, gdy od początku przechodzę nieszczęsne dzieje „Przedświtu”? Jakżem marzył o jednym zakładając to pismo, o czym nieraz mawiałem Księdzu Arcybiskupowi, by utorować Jemu drogę nową ideą społeczną, na którą przyszła chwila, a która by wyniosła na skrzydłach Księdza Arcybiskupa!

a Powyżej niebieską kredką, obcą ręką napisano nazwisko: „Teodorowicz” i czerwoną kredką rzymską cyfrę „VII”. List pisany jest na podwójnej, nieliniowanej kartce formatu kieszonkowego. Kolisty, fragmentaryczny znak wodny jest nieczytelny. Brak miejsca wystawienia dokumentu i datacji.

151 Aluzja do listów pasterskich abp. J. Teodorowicza na inaugurację jego pontyfikatu.

a List pisany na 12 stronicach czystego papieru formatu zeszytowego. W lewym górnym rogu strony tytułowej niebieską kredką obcą ręką napisano: „Teodorowicz”. Brak miejsca wystawienia dokumentu i datacji. 
Jakże i teraz na kroku każdym aż do ostatniej chwili z poczucia samego obowiązku wchodziłem w ogólnych konturach (nie drobiazgach) w myśl i potrzeby nie moje, ale Księdza Arcybiskupa. Tak np. szereg artykułów z okazji mego listu pasterskiego przez pierwszorzędne pióro skreślonych nie pozwoliłem drukować, a i w niektórych kwestiach społecznych nie siebie, ale względy Księdza Arcybiskupa li miałem na oku.

O ile zaś nie mogłem się oddać pismu bezpośrednio, o tyle byłem chyba aż nadto wymówiony przez wyjątkowe zajęcia. Słowem, wyszedłszy z założenia służenia Księdzu Arcybiskupowi, torowania Mu drogi dotrwałem dotąd i dotrwałbym był do końca.

Mogło się to nie udać, to rzecz inna, lecz chęci te były zawsze. Ale nawet wedle mego najgłębszego przekonania dzieło się udało mimo niektórych usterek drugorzędnych. Jak dalece się zaś udało, to dopiero pozna Ksiądz Arcybiskup po zwinięciu pisma, gdy ustanie pobudka dla pism innych rywalizacji z „Przedświtem”, gdy Osoba Księdza Arcybiskupa bez podmuchu nowego kierunku społecznego zostanie samą. Ale przypuśćmy, że się nie udało dzieło, że zawiodło. To czy nie zasłużyłem na to, by moje chęci, moje prawdziwe poświęcenie, moje tylekrotne narażanie się na pociski, jeśli już nie ocenić, to bodaj nie deptać. Tymczasem jakże się ze mną postępuje? Nie mówię i nie mam na myśli samego zwinięcia pisma, które w takich warunkach prowadzone było mi istną niewolą, niedozwalającą mi nigdy z niej się wydobyć. Nie sama decyzja, ta tylko zdejmuje ze mnie odpowiedzialność, ta mię czyni nareszcie niezależnym i wolnym. Ale chodzi mi o co innego, chodzi mi o sposób zrobienia rzeczy i postąpienia ze mną, to Księże Arcypasterzu boli mnie i bardzo boli. Chciałem się zamknąć z mym bólem i ani słówko nie pisnąć, ale po rozwadze wypowiem, co mi na sercu leży, tym bardziej, że niektóre rzeczy dotknąć i tak muszę.

Otóż twierdzę i czuję, że mi się staje ciężka krzywda w sposobie zerwania Księdza Arcybiskupa. Kiedy po powrocie z Abbacji w roku ubiegłym z jednej strony widziałem, że Ksiądz Arcybiskup nie osądzał „Przedświtu” z punktu idei przewodniej, dla której go założyłem to jest demokratycznej, która z natury rzeczy musiała się nie podobać konserwatystom i rządowcom, kiedy z drugiej strony nie wiedziałem, czy Ksiądz Arcybiskup zechce bym ja nadal stał przy piśmie na mej nowej godności. Wtedy zgłosiłem w grudniu w obszernym exposé152 moją dymisję, czyniąc zależną mą gotowość prowadzenia też pisma nadal, od zobowiązania się Księdza arcybiskupa i oświadczenia co do sprawy finansowej (pisałem wyraźnie o 30 tysiącach)b. Jeżeli Ksiądz Arcybiskup nie chce dalej pisma, wówczas ja nie mam żadnej o to pretensji jak pisałem, a nawet zobowiązuję się długi pisma w znacznej części pokryć, gdyż przed konsekracją rząd mi na pismo da.

W tym długim moim exposé naszkicowałem raz jeszcze jak pojmuję stosunek Księdza Arcybiskupa do pisma, jak pojmuję kierunek pisma, a to w tym celu, by Ksiądz Arcybiskup wiedział jasno, jak pismo pójdzie, by więc zostawić Księdzu Arcybiskupowi wolną rękę w decyzji.

Krótko mówiąc dałem do wyboru Księdzu Arcybiskupowi albo pismo zwinąć, albo prowadzić dalej, żądałem wszakże oświadczenia się Księdza Arcybiskupa przed

${ }^{152}$ Fr.: przedłożenie, sprawozdanie.

b Na marginesie ręką abp. Bilczewskiego notatka: „nigdy”. 
konsekracją, a to z tej przyczyny, że po konsekracji tracę możność usprawiedliwienia zwinięcia pisma związanego z mą osobą, a zarazem tracę możność uzyskania pieniężnego poparcia rządu dającego się tylko uzyskać tytułem wycofania biskupa z dziennikarstwa. Ja mogłem pismo zwinąć tylko przed konsekracją, bo po konsekracji zwinięcie pisma mnie i moją osobę eksponowało.

Ksiądz Arcybiskup po długich wywodach, pertraktacjach, które wszystkie wskazywały jak bardzo Ksiądz Arcybiskup życzy sobie prowadzenia pisma nadal, napisał mi wreszcie oświadczenie przed moją konsekracją normujące kwestię finansowania pisma, a zarazem najwyraźniej zaznaczające, że pismo iść będzie dalej.

Otóż księże Arcybiskupie, jakże mam nazwać nagłą decyzję po konsekracji w miesiąc daną, jak nie ciężką krzywdą? Jakże ona inaczej wygląda, jak nie na posunięcie i zaszachowanie mnie moralnie po gotowej umowie? Nie po, ale przed konsekracją był czas naradzania się z biskupami, co oni o piśmie sądzą: po konsekracji, po danym oświadczeniu, do którego żadnych warunków nie było przydanych i które nie było warunkowe lecz bezwarunkowe, każde oświadczenie się Księdza Arcybiskupa, że się wycofuje musiało być krzywdzącym mnie zawodem i to tym bardziej, im jaśniej kwestie wyłożyłem, im więcej czasu było do tego kroku przed konsekracją, im przede wszystkim to w krótszym czasie, bo toż po konsekracji jakby naumyślnie nastąpiło, tak, że gdybym nie znał Księdza Arcybiskupa to bym musiał przypuścić, że tu nie o „Przedświt” idzie, ani o brata, ale o wykierowanie wprost mej osoby.

Jeszcze bardziej krzywdzący jest dla mnie sposób, w jaki to zerwanie nastąpiło. Gdy mam choćby sługę u siebie, to jeszcze mając z nim zerwać naprzód mu zagrożę. „Nie upijaj się, bo pójdziesz precz" albo tym podobnec. Tymczasem Ksiądz Arcybiskup kwitował człowieka, który w pracę włożył pozycję, zdrowie, serce, kwitował go w interesie kolosalnym, bez słówka uprzedzenia, czy choćby pozornego ostrzeżenia. A w jakiej jeszcze chwili? Wtedy, gdy mi zleconym zostało bym dał odpowiedź, czy chcę być nadal przy "Przedświcie”, gdy więc dalsze losy „Przedświtu” uczynił Ksiądz Arcybiskup zależne od mego oświadczenia! Zanim dałem odpowiedź, już zostałem skwitowany z ogromną ujmą dla mej osobistej godności, bo lepiej było przynajmniej nie robić już tego aparatu całego i nie żądać oświadczeń, skoro w myśli było co innego.

Uczucia tego z mej duszy nic już nie wymaże, a wszelkie tłumaczenia się z tego kroku w oczach moich nie są niestety zdolne usprawiedliwić go.

Bo jeśli „Przedświt” kompromitował Księdza Arcybiskupa, to trzeba było z tą ewentualnością liczyć się przedtem i powiedzieć, że warunkowo Ksiądz Arcybiskup przystaje na dalsze prowadzenie pisma, zresztą na to była prosta rada wycofać się pro foro exter$n o^{153}$, ale zobowiązanie wypłacenia, czy podtrzymania pisma do czasu, gdy długi ono swe spłaci, to zostawało i tego należało dotrzymać. Wszak tak było w projekcie spółki z Mycielskim powiedziane: wycofać się wolno, ale zapłacić się musi to, co jako udział przypada.

Na marginesie ręką abp. Bilczewskiego nota: „nagle”.

153 Łac.: na forum zewnętrznym. 
Ksiądz Arcybiskup powołuje się na biskupów, ale nie ma takiej moralnej siły, która mogłaby zmienić raz dane zobowiązanie. Zresztą muszę z bólem serca powiedzieć, że miałem wrażenie, iż przed biskupami zostałem oskarżony zaocznie, bez możliwości obrony z mej strony, a może i bez wzmianki o tym liście z grudnia, gdzie to zdawałem „Przedświt” na ręce Księdza Arcybiskupa. Zaś co do strony materialnej, acz jako plenipotent nie[z]obowiązany do niczego, jednak się zobowiązałem do czynienia kroków, by rząd zapłacił; co gorsza, miałem to smutne wrażenie, że episkopat nic nie wie o tym, że Ksiądz Arcybiskup już był szczegółowe zobowiązanie się na mnie napisał, ja zaś je zaakceptowałem. Nie o złą wolę Księdza Arcybiskupa chcę pomawiać, ale szczerze mówię, co czułem i co czuję. A to uczucie było niestety uczuciem najprzykrzejszym. Nieraz myśląc sobie a i raz pisałem Księdzu Arcybiskupowi, że uważałbym chętnie biskupów za rozjemców w sprawach trudnych. Obraził się o to Ksiądz Arcybiskup, tymczasem co rychlej z episkopatu stworzył trybunał dla mnie poza mymi plecyma. Stało się to może bezwiednie, ale stało się w sposób arcy dla mnie dotkliwy z zawodem i rozczarowaniem, a i upokorzeniem dla mnie.

Dla samej zaś sprawy stała się rzecz niebywała. Oto Ksiądz Arcybiskup zmieniał punkt po punkcie umowy przedkonsekracyjnej, a w ogóle traktował tak sprawę, jakby poprzedniej umowy wcale nie było, jakby oświadczenie Księdza Arcybiskupa nie było padło, jakby nie był niczym Ksiądz Arcybiskup związany i dopiero miał się czymś związać na nowo.

Uderzyło to we mnie jak gromem i nie wiedziałem, co mam myśleć i sądzić o tym. Jakże to być może, by Ksiądz Arcybiskup zmieniał to, co już uważałem za rzecz niezmienną? Czy to ja dziecko jestem, by mi przesłaniać rzecz powagą biskupów i to niepoinformowanych? Czy (myślałem sobie wówczas) Ksiądz Arcybiskup nie zdaje sobie sprawy z konsekwencji? Czy w końcu nie widzi, że pozbawiając trybunału biskupów w oczach moich tego, co jest niezbędne dla poważnego sądu zmusza mnie do zerwania zupełnego w praktyce?

Lecz mimo to wysłuchałem żądań i gotowałem odpowiedź. Aż tu nowy zwrot i nowa decyzja, a i nowe powołanie się na biskupów! Biorę na sędziego Księdza Arcybiskupa samego i proszę powiedzieć z ręką na sercu, jak takie postępowanie nie ma najdotkliwiej ranić i krzywdzić?

Ach, Księże Arcypasterzu! Czy nie lepiej to było wprost i od razu powiedzieć, o co właściwie w całej sprawie chodzi? Czy nie lepiej było mi wprost powiedzieć, że się boicie (biorę tu Księdza Arcybiskupa z całym środowiskiem doradczym) i nie dowierzacie mnie zwłaszcza po mym pasterskim liście? Ja bym ubolewał nad niedowierzaniem, ale wytłumaczyłbym moje stanowisko jeszcze jaśniej. Wtedy mielibyście Wy mnie, jako Waszego, Wam oddanego. A tak? Ja przecie widziałem od początku doskonale, gdzie tkwi oś, około której wszystko się kręci. Ja odczuwałem cały proces, wszystkie niuansyd, wszystkie falowania i przemiany. Niczym mnie nie można było zbyć. Nieraz naprzód już odczuwałem i wiedziałem, co będzie powiedziane. Więc i tak wiedziałem, tylko mnie ta

d Zapis zgodny z oryginałem; poprawnie powinno być: niuanse. 
gra ze mną odpychała, a pobiło mnie wprost w najdelikatniejszym uczuciu ukrywanie właściwego powodu, a zmuszenie kwestią pieniężną do ustąpienia. W tej jeszcze nieszczęsnej kwestii pieniężnej musi Ksiądz Arcybiskup wysłuchać parę uwag. Oto wprost nie rozumiem, jak Ksiądz Arcypasterz może zezwalać na zamknięcie pisma i długi 9 tysięcye, skoro 9 tysięcy pójdą na samo zamknięcie „Przedświtu”, na spłatę zaległości drukarnianych, na 3-miesięczną pensję naprzód płacone każdemu ze współpracowników, którego się tylko oddala, na odszkodowanie tym, których się już z Wiednia (Sarnecki ${ }^{154}$ ), już z Krakowa do pisma sprowadziło, na odszkodowania prenumeratorom rocznym i półrocznym. Wszakże Ksiądz Arcybiskup nie może żądać ode mnie następnie spłaty długów, których spłacić nie jestem obowiązany, ani mogę, bo na pismo zamykające się nikt nie da! Wszak do ciosu moralnego nie będzie chyba Ksiądz Arcybiskup przydawał jeszcze ciosu materialnego bankructwa!

Dlatego proszę Księdza Arcybiskupa uregulować kwestię materialną wedle słuszności, stosownie do własnego oświadczenia, które o tyle wszakże ulec musi zmianie, że arendy na Potockiego, które Ksiądz Arcybiskup czynił i inne muszą być dziś w jakiś sposób powetowane przez Księdza Arcybiskupa. Ja zaś, co uzyskam czy u rządu, czy ze zlania to potrącę i o tyle mniej Ksiądz Arcypasterz zapłaci. Proszę raz jeszcze tę rzecz załatwić i nie zmuszać mnie do żadnych kroków, których bym za nic [na] świecie użyć sam nie chciał. A że pierwszy za plecyma, sprawa i likwidacja nagli, więc proszę w kwestii pieniężnej o odpowiedź zaraz, bo bez niej ruszyć się stąd nie mogę. W końcu proszę darować, gdy co dotknęło Księdza Arcybiskupa. Obrażać nie chciałem i nie chcę, mówiła ze mnie tylko szczerość i żal.

Najoddańsze łączę wyrazy

† Józef Teodorowicz

Dodaję odpis listu Księdza Arcybiskupa i to ustępów poruszających prawną i materialną stronę interesu.

\section{Dokument 33}

Najprzewielebniejszy Księże Arcybiskupie! ${ }^{a}$

List Księdza Arcybiskupa zwrócono w mej nieobecności ze Lwowa do Rzymu sądząc, że tam będę i dopiero teraz otrzymuję ten list z powrotem, zaraz też odpisuję.

e Na marginesie ręką abp. Bilczewskiego nota: „pismo oddam”.

${ }^{154}$ Sarnecki Zygmunt (1837-1922), dramaturg, dziennikarz, krytyk teatralny, tłumacz, dyrektor teatru, redaktor. Pochodził z Podola, uczył się w Odessie i Warszawie, podróżował po Francji i Włoszech. Założył w 1872 r. teatr w Lublinie, obejmując w nim funkcję dyrektora, 1872-1873 dyrektor Teatru Polskiego w Poznaniu, od 1877 r. redaktor dziennika warszawskiego „Echo”. Tworzył sztuki teatralne z gatunku zw. komedią społeczną; w 1885/86 r. objął kierownictwo literackie teatru w Krakowie, 1888-1895 redagował w Krakowie dwutygodnik „Świat”, 1900-1903 pełnił we Lwowie funkcję redaktora dziennika „Przedświt”. W 1904 r. osiadł w Krakowie współpracując z „Nową Reformą”. J. Kowalczykówna, Sarnecki Zygmunt, w: PSB, t. 35, red. zbior., Warszawa-Kraków 1994, s. 211-213.

a List pisany na 12 stronicach czystego papieru formatu kieszonkowego. Dwie kolejne stronice zapisane ołówkiem ręką abp. Bilczewskiego w formie nieczytelnego komentarza do wywodów zawartych w piśmie. 
Podniosłem swe żale i bóle po raz pierwszy, a podniosłem je dlatego, gdyż w tych warunkach uważałem, jak i uważam wypowiedzenie wszystkiego za obowiązek nakazany przez szczerość i prawdę. Spełniwszy tę arcyprzykrą powinność, nie chcę sprawy rozmazywać dalej, właśnie dlatego iż jest osobistą - podporządkowuję ją interesom wyższym dobra ogółu i Kościoła, i z tej też przyczyny żadnej z dotkniętych przez Księdza Arcybiskupa kwestii osobistych poruszać w liście nie będę.

Przeciw jednemu tylko najuroczyściej zaprotestować muszę, jakobym moje zarzuty i moje oskarżenie rozciągał do innych biskupów, albo jakobym im podsuwał jakieś plany co do mej osoby. Przez środowisko doradcze rozumiem innych ludzi, którzy są we Lwowie, ale nigdy biskupów.

Nie, Księże Arcypasterzu! Oświadczenie Księdza Biskupa Pelczara było nacechowane taką życzliwością dla mnie, taką intencją czystą i wyższą, sprawy Bożej taką miłością. Zaś słowa Księdza Biskupa Wałęgi i Jego rozmowa ze mną tuż po konsekracji tak świadczyły ówcześnie o Jego miłości i przyjaźni dla mnie i zrozumieniu mego stanowiska, że ja dla tych obu książąt Kościoła nie żal czuję, ale żywą wdzięczność, nie pogardę jak mi to insynuuje Ksiądz Arcybiskup raniąc mnie tym najdotkliwiej i najniesprawiedliwiej, ale najżywszy szacunek i najszczerszą przyjaźńb. Tyle o osobistych sprawach.

A teraz o sprawie pieniężnej. Co do niej jest między nami niezrozumienie się w samym punkcie wyjścia. Ksiądz Arcybiskup zdaje się tę sprawę traktować jako akt łaski, ja zaś ją biorę jako należność prawną, która posiada wszystkie żądane warunki do prawomocności żądań konieczne. Więc ani żądam współczucia nad sobą, ani łaski jakiej, ani nawet sam stawiam jakieś postulaty od siebie - domagam się tylko jednego - dotrzymania przez Księdza Arcybiskupa umowy, która jakkolwiek nie została za kontraktem uroczystym spisaną, to jednak zupełnie co do siły prawnej aktu równoważy się kontraktowi, gdyż się opiera na pisemnym oświadczeniu Księdza Arcybiskupa danym mnie, a raczej mojemu bratu pośrednio, a zaakceptowanym przeze mnie już też oświadczeniem uczynionym przez Ks. Sapiehę, już też przede wszystkim zaakceptowanym samym faktem prowadzenia pisma dalej i pozostania za wolą wyrażoną Księdza Arcybiskupa mego brata dalej przy redakcji po jego rezygnacji. To dla prawnej mocy i siły aktu jest zupełnie wystarczającym.

Nie mam niestety w tej chwili pod ręką tej umowy spisanej przez Księdza Arcybiskupa, gdyż ustęp określający pretensje brata dałem był jemu, a jego tu obecnie nie ma - wszakże niedawno przytoczyłem ją Księdzu Arcybiskupowi dosłownie - więc wystarczy już, skoro teraz streszczę główne punkta i ujmę ze strony prawnej.

Ustęp cały zawiera 2 strony. Jedna odnosiła się do przeszłości, druga do przyszłości. I. Co do przeszłości zobowiązuje się Ksiądz Arcybiskup do:

A) zapłacenia połowy długu,

Stronice 5-8 noszą liczne ślady rozmazanego atramentu. W lewym górnym rogu karty tytułowej obcą ręką niebieską kredką napisano: „Teodorowicz”. Powyżej notatka ołówkiem ręką abp. Bilczewskiego: „Na to, co mogłem odczytać, odp[isałem]”.

b Na marginesie ręką abp. Bilczewskiego notatka: „Ks. Wałęga ostrzegał, czy ks. b[iskup] Pel[czar], czy ma ludzi - do 15 tys[ięcy]". 
B) do umożliwienia spłaty drugiej połowy z różnych źródeł, które umożliwia wychodzące i żyjące pismo.

II. Co do przyszłości:

A) od tej chwili bierze Ksiądz Arcybiskup pismo materialnie na siebie, zarządzając jego stroną materialną przez komitet,

B) moralnie także, z tą odmianą, iż tymczasem ustanawia Ksiądz Arcybiskup „prowizorium”, które mają stanowić do wyboru nowej redakcji „moi ludzie”.

To prowizorium nie miało żadnych bliższych warunków zawarowanych przez Księdza Arcybiskupa. A więc czy redakcja prowizoryczna miała kierunek, czy nie miała żadnego, czy było po myśli, czy nie po myśli, to wedle tenoru umowy było rzeczą w niczym sam akt zobowiązania nieosłabiającą.

Toteż zarzut, że podczas prowizorium redakcja była niezdarną, może mieć co najwyżej osobiste znaczenie, ale nigdy nie może mieć znaczenia prawnego jakiegoś powodu, a to dlatego, że Ksiądz Arcybiskup nie zobowiązał się do prowadzenia pisma pod warunkiem, że prowizorium będzie takie czy owakiec, tylko po prostu sam to prowizorium ustanawia, polecając bratu prowadzić pismo dalej czy też mnie przez moich ludzi. Sam więc za to zarządzenie odpowiedzialność bierze, a po wtóre żadnych zgoła, żadnych warunków co do sposobu prowadzenia pisma i kierunku nie określa ${ }^{\mathrm{d}}$.

Stąd wnioski:

1) że Ksiądz Arcybiskup zobowiązuje się dać 9 tysięcy, obecnie nie dotrzymuje tym samym zobowiązania samego zapłacenia połowy długów,

2) że Ksiądz Arcybiskup uniemożliwiając prowadzenie pisma przez usunięcie swej subwencji i udziału sam odpowiada za akt zamknięcia pisma (mówię o odpowiedzialności prawnej) i musi też ponieść dlatego wszystkie prawne następstwa.

Prawnym następstwem zaś pierwszym jest uniemożliwienie spłaty drugiej połowy długów, której warunkiem jest istnienie pisma. Za to uniemożliwienie spada odpowiedzialność prawna na Księdza Arcybiskupa i nie wolno prawnie usunąć się od tego, gdyż $\mathrm{w}$ takim razie jest to niedotrzymanie punktu umowy wyrażonego pod liczbą I-B. Powody zaś przez Księdza Arcybiskupa przytoczone jak rzekłem, w niczym nie osłabiają prawnej strony umowy.

Wobec tego jest Ksiądz Arcybiskup zobowiązany skutkiem usunięcia się z pisma:

a) zapłacić połowę długów,

b) umożliwić pobór drugiej połowy z jakiego innego źródła, które by dorównywało możliwości kompensaty istniejącemu pismu,

c) ponieść koszta od chwili, kiedy na mocy oświadczenia wziął Ksiądz Arcybiskup pismo na siebie, a także koszta związane z rozwiązaniem pisma.

Te same prawie zobowiązania prawne byłyby w tym wypadku, gdyby nawet Ksiądz Arcybiskup chciał się powoływać na oświadczenie swoje zapłacenia 9 tysięcy. Bo prawnie całkiem inaczej wygląda rzecz, gdy Ksiądz Arcybiskup daje to zobowiązanie przyłączając je do żywego pisma, a całkiem inaczej, gdy je przyczepia do pisma podciętego materialnie

c Na marginesie karty ręką abp. Bilczewskiego nota: „Sztuczki adw[okackie]”.

d Na marginesie karty ręką abp. Bilczewskiego nota: „Przecież ostrzegałem, prosiłem”. 
przez siebie. Inaczej wygląda, gdy mówię komu: „dam ci 9 florenów i drzewo rodzące owoce”, a inaczej: „daję ci 9 fl[orenów] i drzewo ścięte, które ty w dodatku uprzątnij”. W pierwszym bowiem wypadku mogę resztę długów spłacać przez wciąganie udziałowców, przez rozłożenie długów na raty, w drugim zaś to całe źródło mi odjętym zostaje, a więc prawna kwestia $\mathrm{z}$ gruntu zostaje zmienioną. Tego zaś odrębnego momentu zmieniającego zupełnie i z gruntu akt zobowiązania Ksiądz Arcybiskup zupełnie nie bierze w rachubę, tak jakby on zupełnie a zupełnie nie istniał. Tyle co do prawnej strony zobowiązania Księdza Arcybiskupa.

Roiłem sobie dawniej, że będzie inaczej, że znajdę ludzi z pieniędzmi, około „Przedświtu" ich zgrupuję, że będę mógł spłacić Księdzu Arcybiskupowi połowę przynajmniej długu etc. etc. ... tymczasem naraz Ksiądz Arcybiskup podcina wszystko jednym niespodziewanym zamachem. Nie mówię o jego moralnej stronie, ale czysto o jego finansowej doniosłości. To od razu do niepoznania zmienia cały stan i obraz finansowy strony. Z tą chwilą przestaje być „Przedświt” pismem, na które udziały da się zbierać i subwencje, a nawet wprost nie pozwala dłużej rozkładać choćby raty przeszłych długów, ale jak drzewo przed chwilą żywe naraz podcięte jest z przedsiębiorstwa naraz finansowym trupem i nie tylko nie pozwala na żadne plany na przyszłość, ale nawet zmusza to przedsiębiorstwo z całą bezwzględnością spłacić te zaległości, które w normalnych warunkach latami całymi by się spłacać mogły. Takie straszliwe przeistoczenie prawnej strony i finansowej rzeczy przedstawiło się oczom moim, podobnie jak się przedstawia np. kamienica, na którą zaciągano pożyczki duże na lokatorów, a która naraz w gruzy się rozpada.

Te finansowe następstwa tego aktu ustąpienia odebrały mi wszelką wolność w załatwieniu tej sprawy i wtłoczyły w to położenie przymusowe i położenie bez wyjścia, które mię skazują na jedną konieczność domagania się bezwzględnego dotrzymania danych zobowiązań.

Kiedy przedtem mogłem był i byłbym w stanie pomóc Księdzu Arcybiskupowi przez zebranie udziałów itp., dziś to wszystko odpada, bo na martwe pismo nikt nic nie da, a domagając się od Księdza Arcybiskupa prawnego załatwienia sprawy mogę tylko tę jedną pomoc obiecać, iż pieniądze, które mi się uda dostać z rządu potrącę z cyfry długów ogólnej. Czy to będzie suma wielka - nic dziś powiedzieć nie mogę. W każdym razie trudności tu napotykam, bo dać na pogrzeb nie chcą chętnie i bodaj czy dadzą wiele.

Taki to jest obraz prawnej kwestii, której załatwienia się domagam od Księdza Arcybiskupa raz przymuszony do tego sytuacją stworzoną przez ten nagły cios finansowy, po wtóre zmuszony i tym także, że w grę wchodzi tu mój brat, któremu gdy wniósł rezygnację Księdzu Arcybiskupowi i od pisma odchodził, rzekłem: „Oto masz oświadczenie Ks. Arcybiskupa co do załatwienia sprawy Twojej, daję ci dotyczącą osnowę - na tym spokojnie polegaj". I on na tej podstawie jął się angażować dalej, a dziś zagrożony jest nie tylko kompletnym bankructwem, ale i atakami prawnymi niezaspokojonych wierzycieli. Dziś tedy jest w grze między nami nie już sprawa serca, osobistych pretensji czy żalów, ale po prostu kwestia prawna i finansowa, której załatwienia i wyrównania z powodów wzwyż przytoczonych domagać się muszę i będę.

Łączę wyrazy głębokiego szacunku, sługa oddany 
Przepraszam za okropne pismo a zarazem dodaję jeszcze prośbę, by mianowicie nie były puszczane w obieg z biur Romerów et tutti [... $]^{\mathrm{e}}$ wieści o cofaniu się Księdza Arcybiskupa z pisma. Dziś one z Wiednia dostały się do Lwowa i dalej; tymczasem nie tylko daje to powód do arcyniesmacznych i głupich komentarzy jak np. dlatego, że Ksiądz Arcybiskup chcąc zostać tajnym radcą wyparł się niezależnego pisma na żądanie rządu, stawiającego to za warunek; nie tylko rozsiewa pogłoski coraz głośniejsze o naszym nieporozumieniu, ale przede wszystkim to obniża wartość pisma, za które tym mniej się dostanie, im bardziej ludzie wiedzą, iż je zamknąć muszą.

Lwów, dn[ia] 20/IV [1|902

\section{Dokument 34}

Najprzewielebniejszy Księże Arcypasterzu! ${ }^{a}$

Dopiero wczoraj wieczorem przyjechałem, więc dlatego dziś dopiero na list Waszej Arcybiskupiej Mości odpisuję.

Wyczerpałem wszelkie środki, które by mogły prowadzić do łagodzenia rozdzielającej nas sprawy, a skoro wysiłki były nadaremne zmuszony byłem szukać dróg pośrednich. Używam wyrazu „zmuszony”, gdyż widmo procesu cywilnego, o którym wie dobrze Wasza Arcybiskupia Mość, przynagliło mnie do oświadczenia tam gdzie należy, że ja żadnej nie biorę odpowiedzialności za to, co się w najbliższej przyszłości stać może i najniezawodniej stanie. Tym samym sprawa sama stanęła przed forum nuncjatury ${ }^{155}$. Wobec takiego stanu rzeczy nie wolno mi żadnym krokiem wyprzedzać toku sprawy, a każde oskarżenie przed inne wniesione forum, w takim razie niepowołane, czy cywilne, czy duchowe miałoby na sobie właśnie charakter takiego uprzedzania wyroku właściwej instancji.

Co innego oczywiście gdybym w jakikolwiek sposób został pierwszy sprowokowany, bo wtedy musiałbym się bronić. Wyrozumie tedy Wasza Arcybiskupia Mość, że mi jest niemożebnym przychylić się do życzenia Waszej Arcybiskupiej Mości, bym wygotował oskarżenie dla użytku Jego Kapituły.

Dodając w końcu, że z Ks. Arcybiskupem Hryniewieckim ${ }^{156}$ od roku nie widziałem się wcale, ani doń pisałem, łączę wyrazy szacunku i poważania

† Józef Teodorowicz

e Tekst nieczytelny.

a Powyżej obcą ręką napisano niebieską kredką nazwisko: „Teodorowicz”. List pisany jest na podwójnej, nieliniowanej kartce formatu kieszonkowego. Brak miejsca wystawienia dokumentu i datacji.

155 Zatarg pomiędzy abp. Bilczewskim a abp. Teodorowiczem na tle losów „Przedświtu” znalazł swój epilog w nuncjaturze wiedeńskiej. Dnia 28 XI 1902 r. przemyski bp Józef Sebastian Pelczar pisał do abp. Bilczewskiego: „Bardzo mię zmartwiła wiadomość, że ks. arc[y]b[isku]p Teodorowicz wniósł skargę na Waszą Arcybiskupią Mość przed nuncjuszem; spodziewałem się bowiem, że ta sprawa da się załagodzić. Teraz alea iacta est; trzeba się bronić”. M. Kras, Bp Józef Sebastian Pelczar. Wybór pism, NP, t. 29, Kraków 1968, s. 174.

156 Właściwie: Hryniewicki Karol (1841-1929), święcenia kapłańskie w 1867 r. w Petersburgu, 1883-1885 bp wileński; za działalność patriotyczną i walkę z rusyfikacją zesłany przez władze carskie 2 II 1885 r. do Jarosławia n. Wołgę, zwolniony w $1890 \mathrm{r}$. bez prawa powrotu do diecezji, zrezygnował z urzędu; w $1891 \mathrm{r}$. 


\section{Dokument 35}

\section{Wasza Arcybiskupia Mość! ${ }^{a}$}

Proszę darować, że dopiero teraz odpisuję, ale ciągle aż do tej chwili byłem przeszkodzony. Wczoraj oświadczyłem Księdzu Biskupowi Pelczarowi, że się zgadzam tak na sąd polubowny, jak i na dobrowolną ugodę ${ }^{157}$. Przy dobrowolnej ugodzie zrzekłbym się pretensji, którą bym podniósł przy sądzie polubownym, mianowicie o odszkodowanie za czas od ustąpienia Waszej Arcybiskupiej Mości; motywem zaś by jej było to, iż wprawdzie Wasza Arcybiskupia Mość uwiadomił mnie był, że występuje z „Przedświtu” i powiedział, że na „Przedświt” da pewną sumę, ale de facto ja tej sumy nie otrzymawszy nie mogłem, nie byłem w stanie pisma zwinąć, co też wspominałem w jednym z listów. Bo by pismo zwinąć, potrzeba w tej chwili długi wszystkie wypłacić, by zaś wypłacić muszą być pieniądze. Więc skoro kto powoduje zwinięcie przedsiębiorstwa przez cofnięcie się, musi je także umożliwić przez wypłatę natychmiastową tej sumy, która się od niego należy.

Otóż cała ta kwestia prawna w ugodzie dobrowolnej stałaby się bezprzedmiotową, bo ja bym wtedy rezygnował z pretensji do kosztów za pismo przez cały czas od chwili ustąpienia Waszej Arcybiskupiej Mości aż do teraz. Natomiast określiłem pewne kwantum minimalne 17 tysięcy, na siebie biorąc już spłacenie połowy długów i wszystkich kosztów za prowadzenie tak długie pisma. Mówiłem wyraźnie Ks. Biskupowi Pelczarowi, że liczę na jego 3 tysiące ${ }^{158}$, na Waszą zaś Arcybiskupią Mość 17 (razem 20).

mianowany arcybiskupem tytularnym Perge, osiadł we Lwowie jako kanonik Kapituły Metropolitalnej. Kilka lat przed śmiercią przeniósł się do miejscowości Kozaki k. Złoczowa, gdzie pełnił funkcje duszpasterskie. Po śmierci pochowany został obok miejscowego kościoła. P. Nitecki, Biskupi, s. 82-83; informacja własna autora.

a Powyżej obcą ręką napisano niebieską kredką nazwisko: „Teodorowicz”. List pisany jest na podwójnej, nieliniowanej kartce formatu zeszytowego. Znak wodny przedstawia, w zdobionym obramowaniu, napis: „Margaret Mill Ivory Paper”, a pod obramowaniem napis: „Vienna Manufacture”. Brak miejsca wystawienia dokumentu.

157 Bp Pelczar w liście do abp. Bilczewskiego z 15 XII 1902 r. informował, że jego intencje zostały opatrznie zrozumiane przez abp. Teodorowicza. Pomysł zwołania sądu polubownego wyszedł wprawdzie od bp.Pelczara, ale miała to być ostateczność na wypadek, gdyby ugoda dobrowolna nie doszła do skutku. M. Kras, Bp Józef Sebastian Pelczar, s. 175.

158 Bp Pelczar twierdził, że kwotę 3000 zł reńskich usiłował wmówić mu abp. Teodorowicz. Tymczasem on zadeklarował na 1902 r. inną stawkę. Obiecał wypłatę w styczniu 1902 r. 1000 zł reńskich - czego zresztą dotrzymał - ale dalszą subwencję uzależnił „od okoliczności”. Ostatecznie w 1902 r. wypłacił żądaną sumę 3000 zł reńskich. Aby nie dopuścić do procesu sądowego pomiędzy zwaśnionymi hierarchami lwowskimi, bp Pelczar zobowiązał się wyasygnować w 1903 r. kolejne 3000 zł reńskich. Rekapitulując swoje zaangażowanie w tej sprawie, pisał 15 XII 1902 r. na pół żartobliwie, na pół złośliwie do abp. Bilczewskiego: „Więcej niech Wasze Arcybiskupie Moście nie żądają ode mnie, bo i tak ledwie dycham pod brzemieniem wydatków. [...] Przecież z Waszą Arcybiskupią Mością mierzyć się nie mogę, bo by to było głupią i śmieszną zarozumiałością! A więc niechże mój Metropolita daje przynajmniej dziesięć razy więcej, a może by też ofiarował kilka tysiączków na katedrę przemyską?” M. Kras, Bp Józef Sebastian Pelczar, s. $175-176$. 
W każdym razie bez względu na niego, na 17 tysięcy zupełnie poprzestanę, jakkolwiek do Niego jeszcze osobno pukać będę. Mówiłem zaś o połowie długu 30 tysięcy w równych ratach i określiłem w przybliżeniu, tę zaś kwotę 17 tysięcy podkreśliłem teraz bez względu na ilość długów, tylko jako minimum odszkodowania całej pretensji.

Zastosuję się najchętniej do życzenia Waszej Arcybiskupiej Mości i wszystko wyłożę co do tych przyszłych losów „Przedświtu”, tylko proszę jeszcze o cierpliwość co do czasu. Mogę to zrobić bowiem dopiero po załatwieniu sprawy między nami, by nie mieszać tych dwu odrębnych rzeczy, a potem jeszcze nie wszystko jest ostatecznie złożone i przed 15-tym grudnia ma być parę definitywnych narad, po których dopiero rzecz jako całkiem już gotową i skończoną będzie można uważać.

Przy tej sposobności łączę dla Waszej Arcybiskupiej Mości wyrazy szacunku głębokiego

† Józef Teodorowicz

Sobota, 6/XII [1]902

\section{Dokument 36}

Najczcigodniejszy Kochany Księże Arcypasterzu! ${ }^{a}$

Wiedeń, 7/XII [1]902

Nie wiem czy list ten dojdzie jeszcze do rąk Księdza Arcybiskupa, więc spieszę się jak mogę. Księże Arcybiskupie! To nie ja decyduję o losach „Przedświtu”, ale Ksiądz Arcypasterz zdecydował już o nich cofając subwencję. Nie na mnie więc odpowiedzialność spoczywa za losy „Przedświtu”. Tyle, co do uwagi wstępnej w liście Księdza Arcybiskupa.

Ksiądz Arcybiskup chce bym się sam zajął likwidacją „Przedświtu”. Proszę wszakże na wszystko zważyć bliżej, jakiej to doniosłości jest likwidacja pisma, ile z nią sprzęga się kwestii, a wtedy sam Ksiądz Arcypasterz osądzi, że taką rzecz musi się obmyślać wspólnie. Przede wszystkim w każdym piśmie, a i w „Przedświcie”, zaangażowani są w różny sposób różni ludzie. Zapewne powie mi Ksiądz Arcybiskup: tyś ich angażował, ty ich teraz zaspokój. Ale poza tym zaspokojeniem czysto prawnej natury, pozostaje jeszcze pewien moralny obowiązek nie puszczać z kwitkiem tych ludzi, którzy sprawie katolickiej służyli. Co do brata, to tego biorę na siebie, bo dla niego mam miejsce w banku. Ale taki np. Madurowicz. Taki świeżo z Wiednia zaangażowany Sarnecki etc. Coś więc trzeba pomyśleć o nich, by im coś przecie wynaleźć w miejsce pisma. Gdyby więc Ksiądz Arcybiskup nie miał nic zgoła z „Przedświtem”, to jeszcze byłbym prosił o pomoc w tej mierze w imię sprawy katolickiej.

Po wtóre: Nie może być również obojętnym Księdzu Arcybiskupowi, w jaki sposób pismo egzystencję zmienia. Z kim się połączy, czy też nie połączy.

Po trzecie: Potrzebne jest na ten pogrzeb wydać jakąś odezwę, jakąś bodaj próbkę uzasadniającą ten krok. Jak przestanie [wydawania] pisma jest klęską sprawy katolickiej,

a Powyżej obcą ręką ołówkiem napisane jest nazwisko: „Teodorowicz”. List pisany jest na trzech podwójnych, nieliniowanych kartkach formatu kieszonkowego. 
tak taka odezwa jest bodaj usprawiedliwieniem się tych, którzy chcieli, a nie mogli. Chciałbym tedy pomyśleć o takiej odezwie wspólnie, choć oczywiście nie wyszłaby ona wprost ani ode mnie, ani od Księdza Arcybiskupa tylko od odchodzącej redakcji.

Po czwarte: Sfinansowanie pisma również nie tylko mnie obchodzi. W grudniu pisałem obszerny list Księdzu Arcybiskupowi, składając losy „Przedświtu” w Jego ręce i podkreślając to niejednokrotnie i później, że proszę o decyzję przed moją konsekracją, gdyż przed konsekracją mogę uzasadnić zaprzestanie wydawania pisma i mogę od rządu wydostać pieniądze przedstawiając mu konieczność zerwania z pismem. Tymczasem po różnych ewolucjach naszych wspólnych napisał mi Ksiądz Arcybiskup list przed konsekracją pośrednio będący odpowiedzią na list brata wnoszącego rezygnację, a w tym liście prócz odpowiedzi dla niego na me ręce przysłanej, były także najogólniejsze wytyczne dla "Przedświtu” na przyszłość. Szkoda, że list ten jest we Lwowie, bo miałbym ochotę go tu zacytować. Ale jak sobie Ksiądz Arcypasterz przypomni, w liście tym najwyraźniej oświadcza Ksiądz Arcybiskup, że przez komitet będzie pismo prowadził sam finansowo, że redakcję ustanowi etc. Słowem, że „Przedświt” ma wychodzić dalej do dalszych zarządzeń tak samo kierowany przez dotychczasową redakcję. Wobec takiego oświadczenia Księdza Arcybiskupa, ja zaniedbałem skorzystać z jednej mi się nastręczającej sposobności wycofania się z „Przedświtu” i z honorem, i bez bankructwa. Dzisiaj nie wiem, co i jak mi się uda z rządem, będę tu próbował, ale sądzę, że pójdzie już trudniej. Namiestnikowi przynajmniej już coś ogólnie napomykałem, ale jakoś wywinął się. Jeszcze popróbuję tutaj. W każdym razie wspólnymi silami dałoby się uzyskać więcej, a im więcej dadzą, tym dla obu nas lepiej. W każdym razie sądziłbym, że i to jest sprawa nie tylko moja.

Ale jeszcze przystępuję do kwestii całkiem pobocznych, a dotkniętych przez Księdza Arcybiskupa. Ma widoczną pretensję Ksiądz Arcybiskup, że obiecałem omawiać kierunek „Przedświtu”, a tego nie uczyniłem. Otóż proszę sobie przypomnieć, że byłem u Księdza Arcybiskupa na wyjezdnym i mówiłem o Sarneckim, który obejmie redakcję i pismo pokieruje. Tymczasem, gdy wracam z rekolekcji z Brzeżan, już zastałem list Księdza Arcybiskupa i wycofanie. A więc przede wszystkim kierunek pisma nie zmienia się w 3 dniach, po wtóre myślałem o przyszłości najbliższej, gdy Sarnecki obejmie redakcję, po trzecie Ksiądz Arcybiskup przecie wiedział dobrze, że na wsiadanym byłem do Brzeżan, a więc udział mój w piśmie był niemożliwy; po piąte zresztą przygotowywałem cały program reformy, który bez planu wytycznego danego redaktorowi jest niemożliwy.

Co do sprawy bierzmowania ${ }^{159}$, to proszę Księdza Arcypasterza raz jeszcze uważnie przejrzeć mój list, a tam ani śladu nie znajdzie się wzmianki o jakimś żalu do Księdza Arcypasterza. Nawet w ogóle nic a nic nie wypowiadałem, co sądzę o tym zarządzeniu Księdza Arcybiskupa. Nie mam też żadnej zgoła pretensji do tego, by się Ksiądz Arcybiskup ze swego kroku tłumaczył.

W sprawie Krzysztofowicza ${ }^{160}$ najchętniej bym się zgodził na to, gdyby nie wzgląd na to, że tak mało mam diecezjan i że ci by mi za złe to wzięli, jak o tym wiem, znając ich. Prosiłbym też Księdza Arcybiskupa, by mu Ksiądz Arcypasterz nie wspominał o tym,

159 Zob. list 37 niniejszej części.

160 Osoba niezidentyfikowana. 
że chciał mu dać radę, bo to by go mogło w fałszywy stosunek do mnie postawić. Będę zdaje się w Rzymie sam i tę sprawę przygotuję리.

Jeszcze jedna uwaga. Prosiłbym w tajemnicy trzymać plan co do „Przedświtu”, bo więcej się da uzyskać w targu czy z rządem, czy z kim innym gdy nie będą o tym wiedzieć, że pismo się zwija z musu. Dziękuję za życzenia dla mej pracy, która tu rozpoczęła się bardzo dobrze, bo przy napływie osób znacznie większym niż w roku przeszłym.

Łączę najoddańsze wyrazy czci i szacunku

† Józef Teodorowicz

\section{Dokument 37}

Najczcigodniejszy Kochany Księże Arcypasterzu!

Wtorek, 11 [XII 1902]

Listem pisanym do mnie Ksiądz Arcypasterz rozstrzygnął o losach „Przedświtu”; "Przedświt” ma więc zostać zwiniętym i ma przestać wychodzić. Chodziłoby teraz o to, ażeby likwidację pisma przeprowadzić jak najrychlej, a z drugiej znowu strony ażeby ją przeprowadzić należycie, bo sposób, w jaki pismo istnieć przestaje jest także wagi niezmiernej dla całej sprawy. Wobec tego, że teraz wyjeżdżam, a i Ksiądz Arcypasterz wyjeżdża musi się niestety przewlec i odwlec wspólna narada i wspólne porozumienie w tej arcyważnej i doniosłej sprawie, do której sądzę trzeba będzie jeszcze wezwać i Księdza Biskupa Pelczara. W każdym razie będąc teraz we Wiedniu poczynię pewne ogólne ku temu przygotowania, później zaś po powrocie Księdza Arcypasterza naradzimy się już na pewnych danych nad sposobem likwidacji pisma. Tyle na razie o tej zasadniczej sprawie.

Co do bierzmowania to oczywiście przyjmuję do wiadomości oświadczenie Księdza Arcybiskupa i najściślej się do tego zastosuję. Ja bym był nawet nigdy w świecie o żadne tego rodzaju koncesje nie prosił, choćby już dlatego, że choćby pozorów chcę unikać jakobym się chciał mieszać do obcej diecezji. Tylko tą razą ks. Bąkowski ${ }^{162}$ postawił mnie we fałszywej pozycji, gdyż wprzód seminarzystkom ogłosił, że będę bierzmować, zanim się mnie o to zapytał. Drugą zaś przyczyną, dla której to uczyniłem, to był także wzgląd inny, mianowicie na to, iż wobec długoletniej, wiekowej tradycji tak

${ }^{161}$ Prawdopodobnie mowa o zamiarze zmiany obrządku przez wspomnianego Ormianina z ormiańskokatolickiego na łaciński.

a Obok daty, niebieską kredką obcą ręką napisane jest nazwisko: „Teodorowicz”. List pisany jest na podwójnej, nieliniowanej kartce formatu kieszonkowego. Kartka posiada znak wodny przedstawiający godło Austro-Węgier, a w otoku napis: „Millenium [...] 896-1896”. Brak miejsca wystawienia dokumentu.

162 Bąkowski Walerian (1869-1941), święcenia kapłańskie w 1894 r. w obrządku ormiańskokatolickim we Lwowie, 1894-1896 wikariusz w Czerniowcach, 1896-1897 wikariusz w Kutach, 1897-1905 administrator w Brzeżanach, 1905-1918 urlop zdrowotny - zamieszkał w Woronowie k. Horodenki angażując się w duszpasterstwo rzymskokatolickie, 1918-1922 proboszcz parafii ormiańskokatolickiej w Brzeżanach, 1922-1935 proboszcz w Łyścu, 1935-1941 administrator w Horodence; odznaczony orderem Polonia Restituta. T. Zaleski, Stownik biograficzny duchownych ormiańskokatolickich oraz duchownych rzymskokatolickich pochodzenia ormiańskiego w Polsce w latach 1750-2000, Kraków 2001, s. 35-36. 
nawykniono ${ }^{\mathrm{b}}$ do tego, że arcybiskup orm[iański] bierzmował, iż czyniąc inaczej zmuszonym się jest dawać komentarze, dlaczego się nie bierzmuje teraz, choć bierzmowali poprzednicy. W każdym razie w zasadzie poprzednicy moi uważali za pewną przysługę wyświadczoną biskupom łacińskim, a równocześnie ograniczali się do bardziej prywatnego administrowania tego sakramentu bez zapowiedzi, etc. Tego się trzymałem i ja tą razą w Brzeżanach ${ }^{163}$ tak, że gdyby w godzinę po mnie przyjechał biskup łaciński mógłby przez parę dni się dobrze napocić w bierzmowaniu.

Łączę najoddańsze wyrazy czci i szac[unku]

† Józef Teodorowicz

\section{Dokument 38}

Wasza Arcypasterska Mość! ${ }^{a}$

Najzupełniej się zgadzam na załatwienie sprawy w ten sposób, by w kwotę 17 tysięcy wchodziły także 3 tysiące Ks. Biskupa Pelczara. Wprawdzie dla powodów, które przytoczyłem Księdzu Sapieże trudno mi samemu do Niego o to pisać, ale stanowczo Wasza Arcybiskupia Mość po moim obecnym zrzeczeniu się tych 3 tysięcy, ma nie tylko możność, lecz wprost prawo o te pieniądze się upomnieć, gdyż Ks. Biskup Pelczar do tego się zobowiązał bez żadnych zastrzeżeń, więc prawnie jest winien zapłacić. Nie wątpię, że to uczyni także chętnie skoro obaczy, że od tej jego sumy zależy załatwienie rzeczy, która mu tak na sercu leży.

Raczy przyjąć Wasza Arcybiskupia Mość wyrazy mego głębokiego szacunku i czci

† Józef Teodorowicz

15/XII [1]902

\section{Dokument 39}

Wasza Arcybiskupia Mości! ${ }^{a}$

Zrzekłszy się owych 3 tysięcy od Ks. Biskupa Pelczara (pierwotnie jak to pisałem Waszej Arcybiskupiej Mości miały te pieniądze dopełnić 17 tysięcy robiąc kwotę 20), nie mogę pójść w zniżeniu dalej i dlatego niżej od 17 tysięcy pod żadnym warunkiem

\footnotetext{
b Zgodne z oryginałem; w znaczeniu: przyzwyczajono się.

163 Abp Teodorowicz celebrował sakrament bierzmowania w Seminarium Nauczycielskim Żeńskim w Brzeżanach, gdzie uczennicami były katoliczki obrządku łacińskiego. Według prawa kanonicznego musiał na ten akt uzyskać zgodę rzymskokatolickiego biskupa miejsca.

a Powyżej niebieską kredką obcą ręką napisano nazwisko: „Teodorowicz”. List pisany jest na podwójnej, kratkowanej kartce formatu zeszytowego. Znak wodny przedstawia dużą koronę, wstęgę oraz ozdobny napis: „English Crownmill”. Brak miejsca wystawienia dokumentu.

a Powyżej napisane obcą ręką niebieską kredką nazwisko: „Teodorowicz”. List pisany jest na podwójnej, nieliniowanej kartce formatu zeszytowego. Znak wodny przedstawia 2 identyczne napisy: „Star Mill Hand - Made” oraz datę: „1866” umieszczoną wewnątrz sześcioramiennej gwiazdy.
} 
przyjąć ugody nie mogę. Widzę z wczorajszego listu, że Wasza Arcybiskupia Mość przeoczył to, co pisałem przed paru dniami, dlatego powtarzam raz jeszcze, że stając na oświadczeniu z d[nia] 26 stycznia domagam się li tylko co mi się prawnie należy. Chcąc zaś uciąć przykrą sprawę rychlej zrzekam się tego, czego bym musiał dochodzić więcej, mianowicie $\mathrm{z}$ wszelakich pretensji do odszkodowań i strat moich etc. i określiłem cyfrę, która nieomal połowę tego wynosi, do czego nie godząc się dobrowolnie prawne pretensje podnieść musiałbym. Dlatego jeszcze raz oświadczam, że z chwilą niedojścia ugody dobrowolnej cofam pretensje do kwoty 17 tysięcy i rozciągam je do zobowiązań wszystkich wedle uwzględnienia kompetentnych z oświadczenia z d[nia] 26 stycznia wynikłych zobowiązań. Oświadczenie żądane przez Waszą Arcybiskupią Mość w razie przyjścia ugody wystawię.

Przy tej sposobności łączę wyrazy mego szacunku

Lwów, d[nia] 17/XII [1]902

† Józef Teodorowicz

\section{Dokument 40}

\section{Wasza Arcybiskupia Mość! ${ }^{a}$}

Trzy dni już temu jak nadesłałem odpowiedź Waszej Arcypasterskiej Mości na list mi napisany. Wobec tego, że dotąd nie otrzymuję żadnej odpowiedzi, a chodziło o napisanie krótkiego oświadczenia, przeto obawiam się bardzo, czy w ogóle list mój doręczony został, tym bardziej, że nie wysyłałem go przez mego służącego.

$\mathrm{Na}$ wszelki tedy wypadek powtarzam treść listu. Oto przed wszelakim osobistym układaniem się uważam za konieczne wprzód załatwienie formalne całej sprawy i nadesłanie mi oświadczenia. Jeżeli podobne oświadczenia są potrzebne w każdym interesie gdzie niejedna tylko strona, ale obie w takich razach oświadczenia dają, to potem co między nami zaszło uważam podobne oświadczenie jako tak konieczne, że bez niego absolutnie na układ pieniężny przystać nie mogę i muszę ugodzenie się uważać za nieistniejące. W oświadczeniu musi być wyraźnie zawarte, że Wasza Arcybiskupia Mość żadnych pretensji w sprawie „Przedświtu” do mnie nie ma i że żadnych zarzutów co do moralnej strony dotyczącej tej sprawy podnosić nie może.

Łączę wyrazy szacunku i poważania

Lwów, poniedziałek 20/I [1]903

† Józef Teodorowicz

a List pisany na dwóch stronicach czystego papieru formatu zeszytowego. W lewym górnym rogu strony tytułowej niebieską kredką obcą ręką napisano: „Teodorowicz”. W prawym górnym rogu ręką abp. Bilczewskiego ołówkiem nota: „20/I [1]903”.

b Na trzeciej stronicy nota abp. Bilczewskiego: „Na ten list odpisałem 20 I [1]903. W[asza] Ar[cybiskupia] $\mathrm{M}$ [ość]. $\mathrm{B}$ [ardzo] przepraszam, że dopiero dzisiaj odpisuję, ale wciąż mam gości z miasta i prowincji tak, że nawet wieczorów nie miałem wolnych. Jedną rzecz dam W[aszej] Ar[cybiskupiej] M[ości] tj. pismo, że sprawa „Przed[świtu]” została na dniu... załatwioną między nami ku obopólnej zgodzie. Strony moralnej nie tknę, bo ona w ogóle nie należy do ludzi, tylko jest rzeczą naszych sumień i Pan Bóg ją rozsądzi. Nie 


\section{Dokument 41}

Wasza Arcybiskupia Mość! ${ }^{a}$

Lwów, piątek

Tydzień minął jak oddany został Waszej Arcybiskupiej Mości list mój, na który dotąd żadnej nie mam odpowiedzi. Ponieważ to milczenie może mnie upoważniać do wniosku, że Wasza Arcybiskupia Mość trwa w zarzucie na mnie rzuconym - ponieważ jak to dziś odczułem, ja pod żadnym warunkiem pieniędzy z podobnym zarzutem mi danych przyjąć nie mogę, przeto racz Wasza Arcybiskupia Mość mi donieść co mam z pieniędzmi zrobić, czy je odesłać, czy też czekać aż kto ze strony Waszej Arcybiskupiej Mości je weźmie za oddaniem mi mego rewersu, który wydałem mylnie będąc poinformowany, że pieniądze są mi dane jako należytość, którą tedy wobec tej zmiany kardynalnej utrącą swą wartość prawną zupełnie.

Powolny sługa

† Józef Teodorowicz

Pieniądze wszystkie są złożone w banku i na każde dzienne wypowiedzenie natychmiast wydane zostaną.

\section{Dokument 42}

\section{Wasza Arcypasterska Mość! ${ }^{a}$}

Otrzymałem od Ks. Kan[onika] Sapiehy list w odpowiedzi na moją interpelację w znanej sprawie i list ten jest dla mnie zupełną satysfakcją co do postępowania mojego moralnego. Jak z listu bowiem wynika, powiedział Waszej Arcybiskupiej Mości Ks. Sapieha, iż ja życzyłbym sobie rozpatrzenie przez kogoś trzeciego sprawy, by tym więcej rzecz cała na obiektywnej postawie stanęła. To chyba aż nadto wystarczający dowód uczciwości i bezstronności mojego postępowania. Wobec tego mogę zrezygnować z tego, by Wasza Arcybiskupia Mość wypominał o moralnej stronie w Swym oświadczeniu i proszę je wystylizować tak, jak o tym Wasza Arcybiskupia Mość w liście mi napisał, a w takim razie będę mógł uważać rzecz za załatwioną.

Łączę wyrazy szacunku i poważania

Lwów, 21/I [1]903

† Józef Teodorowicz

może wejść w żadne układy pisemne. To moje ostatnie słowo. W każdym moim liście podniosłem najwyraźniej, że ja nic nie mam przeciw temu, że W[asza] Ar[cybiskupia] M[ość] odda sprawę wyższej instancji. Proszę mię tylko powiadomić, kiedy ta sprawa pójdzie do tej wyższej instancji. Ja akta mam gotowe, tylko Ks. Sapieha spisze jeszcze swoje zeznania. Proszę przyjąć wyr[azy] szac[unku] i pow[ażania]. † J[ózef] B[ilczewski]".

a Powyżej obcą ręką niebieską kredką napisano nazwisko: „Teodorowicz”. List pisany jest na podwójnej, nieliniowanej kartce formatu zeszytowego. Brak datacji.

b Zapis zgodny z oryginałem; poprawnie powinno być: utracą.

a U górnej krawędzi karty tytułowej obcą ręką napisano: „Teodorowicz”. Obok ręką abp. Bilczewskiego nota: „Koniec” i „21/I [1]903”. List pisany jest na podwójnej, kratkowanej kartce formatu zeszytowego. Znak wodny przedstawia napis: „Original Neusiedl Bank Post” oraz stylizowany monogram. 


\section{Dokument 43}

Wasza Arcybiskupia Mość! ${ }^{a}$

Załączam tu oświadczenie Waszej Arcybiskupiej Mości, które dla ewidencji zaznaczam, by dać lepiej poznać, o co mi chodzi i od jakiego minimum odstąpić nie mogę. Chodzi o jedno tylko słowo - sprawa. Tak jak jest, to oświadczenie jest tylko jednostronne w swym brzmieniu dając do zrozumienia, że tylko jedna i to mniejsza strona ugody załatwioną została. Zrezygnowałem z osobnego dodatku części moralnej, ale nie mogę się godzić z formułą wykluczającą. Sądzę, że Wasza Arcybiskupia Mość uwzględni to, o czym już raz pisałem i na co się był Wasza Arcybiskupia [Mość] sam zgodził, przepisując w jednym $\mathrm{z}$ listów formułę, jaką dać może, a jaka od dzisiejszej właśnie tym słowem się różni. Łączę przy tej sposobności wyrazy szacunku i poważania.

Powolny sługa

† Teodorowicz

\section{Dokument 44}

Wasza Arcybiskupia Mość! ${ }^{a}$

Oświadczenie Waszej Arcybiskupiej Mości zadowala mnie najzupełniej i cieszę się bardzo, że mogę nazwać dziś sprawę między nami za najzupełniej załatwioną. Tym samym upada dziś ta przeszkoda wciąż nas obu dzieląca i wzajemnie psująca stosunki. Cieszę się tym z głębi mojego serca i dziękuję Bogu za tę chwilę.

Dla Waszej zaś Arcypasterskiej Mości łączę oddane wyrazy czci i szacunku

† Józef Teodorowicz

Do nuncjatury donoszę o załatwieniu sprawy.

Lwów, d[nia] 8/II [1]903

\section{Dokument 45}

Ekscelencjoa, Wasza Arcybiskupia Mości!

Jakkolwiek formalnie sprawa między nami zupełnie jest załatwioną, to jednak moralnie nią jeszcze nie jest. Wasza Arcybiskupia Mość uczynił w tej mierze ze swej strony

a Powyżej obcą ręką niebieską kredką napisano nazwisko: „Teodorowicz”. List pisany jest na podwójnej, nieliniowanej kartce formatu kieszonkowego. Znak wodny przedstawia zdobiony napis umieszczony wewnątrz otoku: „Margaret Mill Ivory Paper” oraz pod nim: „Vienna Manufacture”. Brak miejsca wystawienia dokumentu i datacji.

a Powyżej ręką abp. Bilczewskiego napisana jest ołówkiem nota: „8/2 [1]903” oraz obcą ręką niebieską kredką nazwisko: „Teodorowicz”. List pisany jest na podwójnej, nieliniowanej kartce formatu kieszonkowego. Kartka posiada znak wodny przedstawiający w zdobionym otoku napisy: „Margaret Mill Ivory Paper” oraz: „Vienna Manufacture”.

a Powyżej obcą ręką niebieską kredką: „Teodorowicz” i ołówkiem ręką abp. Bilczewskiego data: ,„1]903” List pisany jest na podwójnej, nieliniowanej kartce formatu zeszytowego. 
wszystko, bo jasno a szczerze przedłożył zarzuty. Do mnie należało dać odpowiedź. Tę napisałem jeszcze na dniu 2 lutego i chciałem zaraz wysłać. Zmieniłem atoli plan, bo sądziłem, że będzie najlepiej odpowiedzieć wówczas, gdy już faktycznie nie będę należał do „Przedświtu”, gdy więc sprawa nas dzieląca będzie za nami. Tymczasem skutkiem tego, iż jeden z panów nowej spółki „Przedświtu” leży dłuższy czas chory w Krakowie na influenzę ${ }^{164}$, przeto ostateczne ułożenie sprawy umowy z nowym redaktorem, spółkę etc. a tym samym moje wycofanie się zupełne przedłuża się $\mathrm{z}$ natury rzeczy i nastąpi gdzieś za parę tygodni dopiero, a samo ogłoszenie zewnętrzne najprawdopodobniej w czasie, w którym mnie tu wcale nie będzie. Wobec tego, by nie nazbyt odwlekać odpowiedź przyspieszam ją odsyłając dotyczący dokument.

Proszę mi wierzyć, że tak jak Wasza Arcybiskupia Mość tak i ja niczego nie pragnę goręcej jak zgody, ale że droga do niej wiedzie przez jasne powiedzenie prawdy, bez owijania w bawełnę, przeto to czynię - tak jak i Wasza Arcybiskupia Mość ze swej stronie ${ }^{b}$ $\mathrm{w}$ tej samej intencji to już uczynił.

Łączę przy tej sposobności dla Waszej Ekscelencji wyrazy głębokiego szacunku † Józef Teodorowicz

Lwów, dnia 29/II [1]903

Przepraszam za przemazany ustęp, ale go dziś wykreślam, bo nie należy ściśle do mej obrony, więc jest niepotrzebnyc.

\section{Dokument 46}

\section{Wasza Arcybiskupia Mość! ${ }^{\mathrm{a}}$}

Exposé moje ostatnie napisałem w tym celu, aby raz dać zupełną odpowiedź, a i spowiedź moją w tym całym wypadku między nami. Samego żadnego osobistego celu nie miałem, a ostatni mój list uważam za zamknięcie zupełne tej sprawy między nami. Dlatego szczegółów poruszonych w liście Waszej Arcybiskupiej Mości więcej nie dotykam i tylko na wyraźne żądanie Waszej Arcypasterskiej Mości gotów bym był ustnie objaśnić każdy szczegół, który Waszą Arcypasterską Mość porusza.

Jeden tylko szczegół teraz dotykam, bo on dotyczy przyszłego naszego stosunku, a mianowicie, że ja nigdzie nie pisałem, jakoby ludzie, co obejmą „Przedświt” mieli walczyć z Waszą Arcybiskupią Mością. Redaktor aż z Londynu sprowadzony może jedynie

164 Przestarzałe określenie grypy.

b Zgodnie z oryginałem; poprawnie powinno być: strony.

c Do listu dołączona osobna kartka z notatką ręką abp. Teodorowicza: „Oświadczam, że nieporozumienia między mną a Ks. Arcybiskupem Teodorowiczem, jakie powstały z powodu wydawnictwa «Przedświtu» zostały na dniu dzisiejszym w całości usunięte i obopólna zgoda ku zupełnemu zadowoleniu obu stron do skutku doprowadzona została. W następstwie czego ja z tytułu «Przedświtu» najmniejszych pretensji do Ks. A[rcybiskupa] Teodorowicza nie tylko nie mam, ale też z tytułu moralnej strony postępowania żadnych zarzutów stawiać nie mogę".

a Powyżej obcą ręką niebieską kredką napisane jest nazwisko: „Teodorowicz”, a ołówkiem ręką abp. Bilczewskiego data: „[1]903”. List pisany jest na podwójnej, nieliniowanej kartce formatu kieszonkowego. Brak znaku wodnego. 
możliwy w Polsce człowiek do redagowania pisma, z pewnością będzie życzliwy Waszej Arcybiskupiej Mości, władzą właściwą pisma i jego kierunek będzie dzierżyć spółkę, której woli redaktor jest wykonawcą, o tej zaś nie mogę powiedzieć, jakie stanowisko zajmie w przyszłości. To tylko zauważę, że jeśliby stanowisko spółki w jej osobistej polityce było niewłaściwym, ja za to absolutnie odpowiedzialności nie ponoszę, bo chyba nie ja temu winien, że Biskupi dali się w organie katolickim wziąć poza nawias. List poczciwego, ale ciasnego, osobiście zrażonego do „Przedświtu” Krotoskiego ${ }^{165}$ odsyłam; tamty ${ }^{\mathrm{b}}$ list stosownie do życzenia Waszej Arcybiskupiej Mości podarłem. Niechaj Wasza Arcybiskupia Mość uważa niniejsze pismo za ostateczne podanie i szczere mej ręki do jedności i zgody.

Łączę wyrazy prawdziwego poważania

† Józef Teodorowicz

Lwów, dnia 7/XII [1]903

O całej tej sprawie między nami i jej szczegółach zachowam zupełne milczenie, a proszę o wzajemne.

\section{Dokument 47}

\section{Najczcigodniejszy Księże Arcypasterzu! ${ }^{\mathrm{a}}$}

Kiedy mi Ksiądz Arcybiskup mówił w kwestii „Macierzy”166, prosiłem by tę rzecz omówić wspólnie wraz z Ks. Lenkiewiczem. Niestety, skutkiem wyjazdu Ekscelencji projekt ten do skutku przyjść nie mógł. Otóż wobec tego, że nie miałem czasu i sposobności jasno cały mój sposób patrzenia na tę sprawę Ekscelencji przedłożyć, ani też poddać krytyce plan Księdza Arcybiskupa względnie omówieniu, wobec tego nadto, że dziś sytuacja wobec ostatnich wypadków zupełnie się zmieniła i to, co wczoraj było dobrem, dziś może być już niemożliwym, proszę najuprzejmiej Waszą Ekscelencję, by ewentualnie omawiając z kimkolwiek, a w szczególności z Ks. Ks. Biskupami sprawę „Macierzy”, nie powoływał się w niczym na mnie ani na moje zdanie. Tylko poczucie odpowiedzialności za jakiś krok, który by mym zdaniem nieugruntowanym o znajomość wszystkich faktów mógł być spowodowany, zmusza mnie do postawienia tej najgorętszej prośby.

${ }^{165}$ Krotoski Kazimierz Michał (1860-1937), studiował historię, geografię i germanistykę na UJ, 18851886 asystent przy Katedrze Historii UJ, 1886-1891 nauczyciel III Gimnazjum w Krakowie i Podgórzu, potem 1891-1904 w Nowym Sączu. Od 1896 r. związany ze Stronnictwem Katolicko-Narodowym, zwalczał socjalizm i ruch ludowy; 1904-1919 dyrektor gimnazjum w Nowym Targu. Członek tamtejszej Rady Miejskiej. W 1919 r. przeniósł się do Wielkopolski i włączył w nurt Stronnictwa Chrześcijańsko-Narodowego; był członkiem Sejmiku Województwa Poznańskiego, delegatem do Rady Szkolnej Okręgu Poznańskiego. Publikował studia mediewistyczne oraz przyczynki z dziejów nowożytnych. M. Tyrowicz, Krotoski Kazimierz, w: PSB, t. 15, red. zbior., Wrocław-Warszawa-Kraków 1970, s. 346-348.

b Zgodnie z oryginałem; poprawnie powinno być: tamten.

a Powyżej obcą ręką niebieską kredką napisano nazwisko: „Teodorowicz”.

166 „Macierz Szkolna” - stowarzyszenie oświatowe założone dla rozwoju szkolnictwa w Polsce. We Lwowie jego twórcą był Józef Ignacy Kraszewski w 1882 r.; wydawało ono i rozpowszechniało literaturę popularną. 
Życząc powodzenia kuracji łączę najoddańsze wyrazy

Wiedeń, 19/VII [1]904

† Teodorowicz

Dokument 48

Ekscelencjo! ${ }^{\mathrm{a}}$

Najczcigodniejszy Księże Arcypasterzu!

Serdecznie dziękuję Waszej Ekscelencji za list, a w szczególności za zaproszenie mnie na konferencję w poniedziałek. Niechaj mi wierzy Ekscelencja, że się tym uradowałem bardzo, widząc dowód ze strony Waszej Arcybiskupiej Mości chęci zjednoczenia wspólnej pracy, a to jest gorącym pożądaniem mego serca. Niestety, w sam poniedziałek przybyć jeszcze nie mogę, gdyż przed tygodniem zostałem zaproszony do Jazłowca ${ }^{167}$. A że tam przez moją nieboszczkę siostrę ${ }^{168}$, która całą edukację w Jazłowcu odbyła, jestem jakby w rodzinie, tam też mi moja siostra wymodliła powołanie, więc trudno by było mi odmówić. Po poniedziałku służę Ekscelencji, jeśli by były jeszcze jakie narady, to na nie $[\ldots]^{\mathrm{b}}$, a jeśli nie, w każdym razie na obiad.

Proszę przyjąć przy tej sposobności zapewnienie o mej oddanej czci i głębokim szacunku

Lwów, 23/IX [1]904

Ks. J[ózef] Teodorowicz

\section{Dokument 49}

Ekscelencjo! ${ }^{\mathrm{a}}$

Lwów, dnia 9/X [1]904

Zaszedł fakt w sejmie naszym, jakiego on jeszcze nigdy nie był świadkiem, o którym czuję się zniewolonym donieść Waszej Ekscelencji. Sejm uchwalił uchwałę o radzie

a List pisany jest na podwójnej, nieliniowanej kartce formatu kieszonkowego. Znak wodny przedstawia w zdobionym obramowaniu napis: „Margaret Mill Ivory Paper” oraz poniżej napis: „Vienna Manufacture”.

167 Jazłowiec - miasteczko w pow. Buczacz, woj. Tarnopol. W 1863 r. Siostry Niepokalanki erygowały tam klasztor i otworzyły szkołę dla dziewcząt.

168 Teodorowicz Katarzyna (1866-1885), siostra abp. J. Teodorowicza. Ukończyła pensję dla dziewcząt u ss. Niepokalanek w Jazłowcu. Zmarła na gruźlicę 25 I 1885 r. w Stanisławowie, ale to m.in. jej przyszły hierarcha zawdzięczał odzyskanie wiary religijnej oraz wymodlenie powołania kapłańskiego. S. Gawlik, Życie i działalność, s. 12; informacja pisemna mgr. Tomasza Krzyżowskiego, Kraków 4 I 2017 r.

b Tekst nieczytelny.

a Powyżej obcą ręką niebieską kredką napisano nazwisko: „Teodorowicz”. List pisany na nieliniowanej, podwójnej kartce formatu zeszytowego. Brak znaku wodnego. 
szkolnej wziętej żywcem z liberalnych majowych ustaw państwa ${ }^{169}$, przeciwko którym zarówno Ojciec Św[ięty], jak i episkopat cały w swoim czasie tak energicznie protestował. Punktem głównym tej ustawy jest wprowadzenie elementów antykościelnych do zarządu naszych szkół. Nie wchodzę zupełnie w momenta polityczne tej sprawy, tylko stwierdzam jej antykościelny charakter. Nie mogąc już obalić samego przedłożenia byłem zmuszony przynajmniej bronić godności episkopatu, ochronić zaniepokojoną katolicką opinię Kraju. W porozumieniu więc z Ks. Metropolitą Szeptyckim i Ks. Biskupem Pelczarem, który mnie upoważnił do przemówienia w imieniu episkopatu, złożyłem w sejmie deklarację, znaną zapewne Waszej Ekscelencji. Na poprzednie porozumiewanie się nie było już absolutnie czasu.

Zmuszony jestem też wyrazić Waszej Ekscelencji żal, jaki nas przejmuje. W tak ważnej chwili Wasza Ekscelencja ze Lwowa wyjechałeś, bo w samym właśnie dniu wetowania uchwały. Wiadomym mi zaś jest, że Wasza Ekscelencja byłeś dawno już poinformowany o projekcie wniesienia tej ustawy. Jako tyloletni członek Rady Szkolnej mogłeś, Ekscelencjo, zdawać sobie sprawę z wagi tego przedłożenia. Mimo to ani sam nie uczyniłeś, Ek[scelencjo], żadnych kroków, aby uchronić Kościół od tego ciosu, ale nawet nie przestrzegłeś nas o grożącym niebezpieczeństwie. Obalenie ustawy w sejmie już się nie udało. Ratowaliśmy tylko nasze sumienia, ratowaliśmy społeczeństwo od obałamucenia, zasłoniliśmy choć w części Episkopat od zarzutu karygodnego niedbalstwa. Trudno i nam będzie obmyć się przed Rzymem, trudno wytłumaczyć nasze zachowanie. Łasce Bożej tylko przypisać możemy, iż choć spóźnionym wystąpieniem spełniliśmy w części nasz obowiązek. Choć mi to ciężko i przykro, ale musiałem to Ekscelencji napisać.

Łączę dla Waszej Ekscelencji wyrazy braterskie i oddane, sługa w Chrystusie

† J[ózef] Teodorowicz

\section{Dokument 50}

\section{Ekscelencjo! ${ }^{\mathrm{a}}$}

Niestety, tenor otrzymanych telegramów nie taki jest, jak tego się spodziewałem i oczekiwałem. Telegram z Rzymu daje do poznania, że gremialny zbór biskupów byłby im nie na rękę, chyba tylko zgodziliby się na uczestnictwo w pojedynkę. Ten telegram muszę zabrać z sobą i dlatego nie doręczam. Do drugiego telegramu klucz jest następujący. Telegrafował Dziembowski ${ }^{170}$, któremu na bytności naszej bardzo zależy. Nie

169 Tzw. ustawa majowa z 1868 r. określająca stosunek szkoły do Kościoła w cesarstwie austro-węgierskim. W 1874 r. wydano kolejne ustawy regulujące położenie Kościoła w państwie. Pozornie dawały one silną władzę wobec Kościoła czynnikom państwowym, ale wykonywane były w sposób dlań zadowalający. Ta ostatnia z wymienionych ustaw wywołała jednak falę krytyki tak ze strony biskupów, jak i papieża.

a Powyżej obcą ręką niebieską kredką napisano nazwisko: „Teodorowicz” i datę: „1912?”. List pisany jest na podwójnej, nieliniowanej kartce formatu kieszonkowego. Brak miejsca wystawienia dokumentu i datacji.

170 Kryptonim bp. Edwarda Likowskiego. 
mógł jednak ukryć tego, że Biskup Likowski ${ }^{171}$, którego pod tą osobistością rozumie, nie przyjmie miło naszego przyjazdu. Doradzając tedy do wczoraj bardzo gorąco Księdzu Arcybiskupowi wyjazd, teraz nie biorę odpowiedzialności i zostawiam najzupełniej osobistemu zdaniu Ekscelencji. Co do mnie, mam tak ważne osobiste powody widzenia się z Ks. Likowskim, że liczę na to, że zrozumie przecie, że nie mogłem się z nim nie widzieć, więc jadę - zwłaszcza po wczoraj otrzymanych informacjach.

Łączę najoddańsze wyrazy czci i szacunku

† J[ózef] Teodorowicz

Ustęp na telegramie dotyczący Likowskiego podkreśliłem i w nawiasie umieściłem w odnośnym miejscu jego nazwisko. Telegram otrzymałem w nocy.

$\mathrm{W}[\mathrm{e}]$ wtorek.

\section{Dokument 51}

Ekscelencjo! ${ }^{\mathrm{a}}$

Najchętniej służyć będę w tej sprawie. Po rozmowie z Waszą Ekscelencją wpadła mi biblia francuska, która by bardzo się nadawała do przetłumaczenia, bo w odpowiednim duchu napisana. Będę się modlił, by Bóg zlewał potrzebne łaski w miarę trudności czasów, w jakich żyjemy i posłannictwa wielkiego, jakie Ekscelencji zlecone.

Najoddańszy sługa

† Teodorowicz ${ }^{\mathrm{b}}$

\section{Dokument 52}

Ekscelencjo ${ }^{\mathrm{a}}$, Kochany Księże Arcybiskupie!

Już w grudniu wiedziałem o gotującym się odznaczeniu Waszej Ekscelencji, ale nie chciałem przed czasem die Geheimnise lüften ${ }^{172}$. Więc spieszę teraz z serdecznymi

${ }^{171}$ Likowski Edward (1836-1915), święcenia kapłańskie w 1861 r. w Gnieźnie, wikariusz w Kcyni i Poznaniu, wykładowca i rektor Seminarium Duchownego w Poznaniu (1867-1873), podczas Kulturkampfu został aresztowany przez władze niemieckie (1874 r.); był oficjałem i wikariuszem generalnym archidiec. gnieźnieńskiej i poznańskiej, kanonikiem Kapituły Katedralnej w Poznaniu, 1887-1914 biskup pomocniczy poznański, wikariusz kapitulny archidiec. poznańskiej (1890-1892, 1906-1914), 1914-1915 metropolita gnieźnieński i poznański. B. Kumor, Likowski Edward, w: SPTK, t. 2, red. H. E. Wyczawski, Warszawa 1982, s. 525-527.

a Powyżej obcą ręką niebieską kredką napisano nazwisko: „Teodorowicz”. List pisany jest na podwójnej, nieliniowanej kartce formatu zeszytowego. Znak wodny przedstawia herb z koroną oraz datę: „1498”. Brak miejsca wystawienia dokumentu i datacji.

b Obok ręką abp. Bilczewskiego ołówkiem dopisana jest data: „20/8 [1]906”.

a Powyżej obcą ręką ołówkiem napisane jest nazwisko: „Teodorowicz” i cyfra „2" List pisany jest na podwójnej, nieliniowanej kartce formatu zeszytowego. Znak wodny przedstawia napis: „Joynson Mill Nr 327”.

172 Niem.: wyjawić tajemnicę. 
życzeniami. Przy tej sposobności tłumaczę się, że nie pisałem z Wiednia, ale to wszystko zaraz rozniosły gazety.

Tu jednak w Tyrolu gotuje się jak w garnku i tyrolczycy wspominają 1809 rok $^{173}$, gotowi dziś iść na awantury Bóg wie jakie. Ja niestety, muszę przerwać zaczęty tu pobyt skutkiem nagłego wezwania mnie do Rzymu. Myślałem, że się oddam bezkarnie dolcze farniente ${ }^{174}$ i w tym celu wysłałem naprzód był papiery, tymczasem nie udało się i jutro w imię Boże lecę do Rzymu. Już naprzód się boję tamtych upałów. Tu już one były nieznośne, cóż dopiero tam będzie.

Prosząc gorąco o modły Waszą Ekscelencję, przesyłam zarazem moją broszurę łącząc najoddańsze wyrazy czci i szacunku

† Teodorowicz

Brixen $^{175}$, d[nia] 21/V |1|908

Gdyby Ekscelencja miał mi co przekazać proszę adresować: hotel Marini Roma.

\section{Dokument 53}

\section{Przezacny Księże Arcybiskupie!}

Zbieram parę myśli pod wpływem konferencji i świeżym jeszcze wrażeniem, by zanim się rozproszą o tyle je zestawić, o ile wspólnej naszej sprawy dotyczą. Nie narzucam się, ale do ewentualnego omówienia czy dyskusji może w mniejszym kółku w Przemyślu ${ }^{176}$ poddaję.

Oto zdało mi się, że jak zmorą zaciążył nad episkopatem duch Koppa. Z pewnością zasługa to jego praktycznych zdolności i sprytu, ale także i całej taktyki zmierzającej do opanowania episkopatu, gdzie dla jednych, jak dla nas, nie szczędzi uprzedzającej grzeczności, dla drugich nawet pieniędzy (na dobre cele), wszystkich chcąc prowadzić na pasku swej opinii. Nie miałbym w końcu wiele przeciw temu, gdyby się ograniczył na uwagi praktyczne i rozumu w poszczególnych sprawach. Ale on idzie dalej i raz po raz sugestionuje całą taktykę swoją socjalną i polityczną. I tu jest on niebezpieczny.

Proszę sobie tylko uprzytomnić. Pierwszy jego atak był w kierunku oświadczenia się przeciw adresowi do francuzów ${ }^{b}$. Wprawdzie nie powiedział wyraźnie: róbcie, co my, ale także nie powiedział: nie róbcie i wszyscy biskupi zostali pod wrażeniem, że Kopp

${ }^{173}$ Tyrol - kraj związkowy w zachodniej Austrii. W 1809 r. wybuchło powstanie przeciw panowaniu bawarsko-francuskiemu w Tyrolu. Ludność stanęła po stronie Habsburgów, ale wojska francuskie opanowały Tyrol, a przywódca powstańców Andreas Hofer został rozstrzelany.

174 Właściwie wł.: dolce far niente - słodka bezczynność, miłe nieróbstwo.

175 Brixen - miejscowość w Tyrolu.

a Powyżej obcą ręką niebieską kredką napisane jest nazwisko: „Teodorowicz”. List pisany jest na dwóch podwójnych, nieliniowanych kartkach formatu zeszytowego. Brak miejsca wystawienia dokumentu i datacji. Znak wodny na obu kartkach przedstawia w ozdobnej ramce napis: „Margaret Mill Ivory Paper”. Poniżej ramki napis: „Vienna Manufacture”. Brak miejsca wystawienia dokumentu i datacji.

${ }^{176}$ Aluzje do planowanego spotkania biskupów rzymskokatolickich Galicji w Przemyślu; nie wiadomo, czy do niego doszło.

b Zapis zgodny z oryginałem; poprawnie powinno być: Francuzów. 
jest przeciw temu, tak, że byli zdumieni, iż on takie rzeczy bierze z politycznego stanowiska, mnie zaś byli wdzięczni (biskup z Laibach ${ }^{177} \mathrm{i}$ inni), że mu przypomniałem, że w Rzymie na taki adres ze strony Austrii czekają. Ale to pierwsze chwilowe niezadowolenie z Koppa ustępowało zupełnie miejsca poddaniu się pod jego batutę. Jemu został oddany list do wiernych i biskupi austriac[c]y wyręczają się uczniami pruskiego biskupa mówiąc do swoich. Tu także wprost veto założył́, by dotykać spraw socjalnych, a zrobił to z naciskiem twardym i silnym (przeciw mnie), ale i wbrew opinii Nagla ${ }^{178}$, Machnicza ${ }^{179} \mathrm{i}$ innych. Machnicz co prawda był na Koppa wzburzony: „nie możemy się jemu dać terroryzować jak małe dzieci" powiadał, ale on jeden to za mało. Stoimy wobec faktu, że bez względu na to, kim on jest w duszy, mamy do czynienia z niebezpiecznym a zręcznym przeciwnikiem. Potrzeba, żeby nasza taktyka wobec niego była jednomyślna i żebyśmy wzajemnie wiedzieli, z której strony zachodzi, zwłaszcza w sprawach Poznańskiego, by snać potem nie wygrywał jednego przeciw drugiemu. Uważam to za rzecz doniosłej wagi i dlatego o tym piszę i do rozmyślenia poddaję.

$\mathrm{Na}$ zakończenie winszuję Księdzu Arcybiskupowi, że choć częściowo przeszedł wniosek w sprawie uniwersytetu. W sprawie katechizmów trzeba będzie także z wielką ostrożnością, ale z całym planem. Wprawdzie i Kopp jest za tym, ale on czując biskupów przeciwnych nie oświadczy się wyraźnie, by swej powagi nie narazić w niczym. Tę sprawę z punktu taktyki naszej dla kraju, a potem szerszej wobec biskupów musimy także omówić w Przemyślu. Także proszę wydostać z konsystorza broszurę Zellera ${ }^{180}$ o reformie religii, o ile być może tą, w której jest mowa już o opiniach ordynariatów poszczególnych.

Ja tu jeszcze zostaję parę dni, a nie jest wykluczone, że może mi wypadnie być na osobnej audiencji u cesarza. Wczoraj także miałem wiele pociechy ze strony biskupów i zupełnie uspokojony dziś jestem, że głosy o moich zaczętych wystąpieniach są tylko ze strony 2 konserwatystów, z którymi toczy się cicha walka. I tak biskup spod Wiednia podnosił, że tyle życia wniosłem na konferencje i inicjatywy. Biskup z Linzu ${ }^{181}$ ulitował

177 Odniesienie do bp. Antona Bonaventury Jegliča (1898-1930), ordynariusza diecezji Laibach (Laybach, Ljubljany) na terenie dzisiejszej Słowenii.

${ }^{178}$ Nagl Franz Xawer (1855-1913), święcenia kapłańskie w 1878 r. w St. Pölten, dr teologii, od 1883 r. prof. egzegezy Nowego Testamentu i filozofii tomistycznej w Seminarium Duchownym w St. Pölten, 18851887 duszpasterz parafii przy dworze cesarskim w Wiedniu, 1887-1889 ojciec duchowny w stołecznym Zakładzie Naukowym dla duchowieństwa „Frintaneum”, w 1902 r. mianowany biskupem Triestu, od 1910 r. abp tytularny Tyru i koadiutor z prawem następstwa wiedeńskiego kard. A. J. Gruschy, 1911-1913 abp Wiednia i kardynał; zreorganizował i zmodernizował formy duszpasterskie, zajął się akcją budownictwa sakralnego, troszczył się o rozwój prasy katolickiej, zorganizował Kongres Eucharystyczny w Wiedniu. F. Loidl, Nagl Franz Xaver, w: ÖBL, Bd. 7, herausg. von E. Obermayer-Marnach, Wien 1978, s. 20-21.

179 Właściwie: Mahnič Anton (1850-1920), święcenia kapłańskie w 1874 r., dr teologii, wykładowca nauk biblijnych w Seminarium Duchownym w Görz, 1896-1920 biskup ordynariusz diecezji Krk (Veglia), zorganizował synod diecezjalny, erygował Starosłowiańską Akademię, promotor słoweńskiej i chorwackiej kultury, zaangażowany w ruch narodowy tego regionu Bałkanów. N. Prašelj, Mahnič Anton, w: ÖBL, Bd. 5, herausg. von L. Santifaller, Wien 1978, s. 413-414.

180 Postać niezidentyfikowana.

${ }^{181}$ Zapewne aluzja dotyczy ordynariusza diecezji Linz bp. Franza von Sales Marii Doppelbauera (1889-1908). 
się nawet nad moją niemszczyzną ${ }^{c}$ radząc, by zabierać nawet głos publicznie, a gdy się składałem ${ }^{d}$ językiem rzekł, że tylko czasem chybiam w mniejszych, które u cudzoziemca nie rażą. Szczególniej łaskawi byli mi biskupi, z którymi się ściślej związałem i z którymi już jakby jednego ducha byłem, musząc nawet czasem tylko dlatego zabierać głos, że sobie tego w tym nienazwanym klubie naszym życzyli. Z pewnością wszystko to nad zasługę moją, ale bądź co bądź dobre jest dla możliwego późniejszego działania, w którym także proszę Was wszystkich o solidarność. Dostałem także od Gruschy ${ }^{182}$ wezwanie na listopad w sprawie „Vaterlandu” ${ }^{183}$, więc także dobrze będzie w Przemyślu tą rzecz omówić, bo dla nas ważna to także rzecz mieć ten dziennik dla nas.

Ale rozpisałem się za wiele więc urywam, łącząc wyrazy najoddańsze

† J[ózef] Teodorowicz

\section{Dokument 54}

Nie $^{a}$ mogłem się Ekscelencji doczekać. Dziś jadę. Z Badenim omówiłem ogólne kontury umowy ${ }^{184}$. W tych dniach nastąpi skrystalizowanie ostateczne i umowa. Udział Ekscelencji określił O. Sopuch ${ }^{185}$ jak pierwotnie do 4 czerwca.

Polecam się pamięci i modlitwie

Teodorowicz

c Zapis zgodny z oryginałem; poprawnie powinno być: niemczyzną.

d Zapis zgodny z oryginałem; w znaczeniu: wymawiałem, tłumaczyłem.

182 Gruscha Anton Josef (1820-1911), święcenia kapłańskie w 1843 r. w Wiedniu, dr teologii, 1843-1846 duszpasterz w Pillichsdorfie, później w par. pw. św. Leopolda w Wiedniu, 1851-1855 prof. religii w stołecznym Teresianum, 1855-1871 kaznodzieja w katedrze pw. św. Szczepana w Wiedniu, od 1863 r. prof. teologii pastoralnej na Uniwersytecie Wiedeńskim, w 1871 r. kanonik Kapituły Katedralnej, w 1878 r. mianowany austriackim biskupem polowym, w 1890 r. objął arcybiskupstwo wiedeńskie, w 1891 r. otrzymał kapelusz kardynalski; patronował budownictwu sakralnemu, był protektorem katolickich stowarzyszeń chrześcijańsko-społecznych. Gruscha Anton Josef, w: ÖBL, Bd. 2, herausg. von L. Santifaller, Graz-Köln 1959, s. 95.

183 „Vaterland” - niemieckojęzyczny katolicki dziennik założony w 1871 r. w Luzernie, organ chrześcijańsko-demokratycznego stronnictwa ludowego.

a List nie posiada tytulatury, miejsca wystawienia ani datacji. Ponad tekstem obcą ręką niebieską kredką napisano nazwisko: „Teodorowicz”. List pisany jest na podwójnej, nieliniowanej kartce formatu zeszytowego.

${ }^{184}$ Zob. list 55 niniejszej części.

185 Sopuch Stanisław (1869-1941), święcenia kapłańskie w 1897 r. w Zakonie oo. Jezuitów w Krakowie, 1891-1894 wychowawca w konwikcie w Chyrowie; 1897-1899 kaznodzieja i organizator katolickich stowarzyszeń robotniczych w Krakowie i 1899-1904 we Lwowie, 1904-1908, 1913-1915 superior domu we Lwowie oraz 1908-1913 domu rekolekcyjnego tamże, 1915-1918 przebywał w niewoli rosyjskiej w Kijowie; 1919-1926 prowincjał galicyjski (małopolski), 1935-1938 prowincjał wielkopolski, 1938-1941 superior w Kaliszu. Sopuch Stanistaw, w: EWJ, s. 633. 


\section{Dokument 55}

\section{Ekscelencjo! ${ }^{\mathrm{a}}$}

Żałowałem mocno, że nie zastałem Ekscelencję wczoraj i tylko naprędce musiałem poprzestać na skreśleniu kilku słów. Otóż jak już wzmiankowałem, drukarnię można uważać tak jak już sprzedaną, gdyż główne punkta umowy tak z Badenim, jak O. Sopuchem przedyskutowane zostały [i] przyjęte obustronnie. Podkład umowy jest prawie ten sam, a raczej ten sam, jaki szkicował Ks. Sopuch przed Księdzem Arcybiskupem i przede mną w swoim czasie. Jest to też zrealizowanie planu, jaki Ksiądz Arcybiskup rozwinąłby przede mną. To j[est], by na czele wydawnictwa i drukarni postawić grupę ludzi ruchliwych i przedsiębiorczych, którzy by też biskupów zasłaniali. Otóż pod tym względem uważam za wygraną przystąpienie do tej akcji Badeniego. Jest to nie tylko człowiek poważny, ale też człowiek, który sobie jasno z tego zdaje sprawę, że jemu cofnąć się nie wolno, a nie wolno też imać się rzeczy, która się nie powiedzie. W tym jest stanowczo wygrana. Co do ceny kupna, to jeszcze spuściłem z ceny 30 tysięcy fl[orenów], tak że sprzedaję drukarnię za 27 tysięcy; nie potrzebuję dodawać, że sprzedaję z dużą stratą. Bo pominąwszy już wkłady, które każda nowa drukarnia, jak to jest wszędzie stwierdzonym, przez kilka pierwszych lat ze stratą czynić musi, ponadto jeszcze tracą literalnie na podstawie przeprowadzonego rachunku. Ponadto wszystko atoli niezaprzeczony zysk moralny w tym tkwi, że nawet i pod tym względem dotąd nie powiem rozdzieleni, ale w każdym razie niezespoleni dziś odnajdziem się w wspólnym towarzystwie wydawniczym; a ponadto, że ruchliwy i młody zastęp ludzi przeprowadzi tę ideę wydawniczą w praktykę i życie, dla której właśnie „Polonia”"186 powołaną została i z której tylko pod tym warunkiem abdykować „Polonii” wolno, iż idea przewodnia nie zostaje zatraconą, ale tylko pod inną nazwą przejętą. Ale rozpisałem się, a tu czas na kolej. Więc informując o przebiegu sprawy i ciesząc się zarazem z jej uwieńczenia łączę wyrazy najoddańsze

Teodorowicz

Wiedeń, 5/XII [1]908

a Powyżej niebieską kredką napisano nazwisko „Teodorowicz”. List pisany na podwójnej, nieliniowanej kartce formatu kieszonkowego. Znak wodny przedstawia litery „TSL” w zdobionym obramowaniu.

${ }^{186}$ Drukarnię „Polonia” założył w imieniu konsorcjum brat abp. J. Teodorowicza - Mieczysław Dawid. Koncesję na drukarnię otrzymał 1 IV 1903 r. Bernard Gustaw Müller, który w 1909 r. wycofał się wraz z koncesją. Kierownictwo drukami objął wówczas Piotr Gawęda. Po nim kierownikami drukami byli: Raczyński oraz Skrabski. W 1. 1914-1918 drukarnia zawiesiła działalność. W 1919 r. drukarnię zakupiło dowództwo frontu południowo-wschodniego gen. Wacława Iwaszkiewicza. W 1920 r. drukarnię rozdzielono pomiędzy Kielce i Lwów. A. W. Bober, Historia drukarń i stowarzyszeń drukarskich we Lwowie. W siedemdziesiata rocznicę powstania Stowarzyszenia "Wzajemnej Pomocy” a w pięćdziesiąta rocznicę zatożenia Stowarzyszenia „Ognisko”, Lwów 1926, s. 18. 


\section{Dokument 56}

\section{Ekscelencjo! ${ }^{\mathrm{a}}$}

Najuprzejmiej dziękuję za łaskawe życzenia. Jak widzę, to obydwaj marudzimy, bo i ja dzisiaj dla niezdrowia krokiem się z domu nie ruszam i dlatego poprzestaję tym razem na przesłaniu życzeń świątecznych najserdeczniejszych Waszej Ekscelencji przeze mnie.

$\mathrm{Z}$ wyrazami prawdziwie oddanymi czci głębokiej i szacunku

24/XII [1]908

† Teodorowicz

\section{Dokument 57}

\section{Ekscelencjo! ${ }^{\mathrm{a}}$}

Wspominałem Ekscelencji, że wyrobiłem dla Pani Zaharyasiewicz ${ }^{187}$ u Ojca Św[iętego] krzyż Pro Ecclesia et Pontifice ${ }^{188}$. Miałem go właśnie jej doręczyć po załatwieniu sprawy Woronowskiej ${ }^{189}$. Tymczasem dochodzi mnie iście nieprawdopodobna wieść, jakoby ona właśnie z rąk Ekscelencji odznaczenie otrzymała. W każdym razie, ponieważ to słyszałem z bardzo wiarygodnych ust, przeto muszę prosić Ekscelencję o wyjaśnienie.

Łączę wyrazy oddane czci i szacunku

† Teodorowicz

Lwów, dnia 7/I [1]909

\section{Dokument 58}

Mój Drogi! ${ }^{a}$

Dziękuję Ci bardzo za Twój dobry list i życzenia tak mi miłe. Ja jednak tak jestem zajęty pertraktacjami i pisaniną w sprawie ustawy dotyczącej naszych kościołów, że istotnie mimo kilkakrotnego zbierania sic do pisaniny do Ciebie czasu mi na to nie stało. I teraz wysyłam $\mathrm{Ci}$ w tej sprawie pismo, które ułożyłem do wszystkich po niemiecku,

a Powyżej obcą ręką napisane jest niebieską kredką nazwisko: „Teodorowicz” i ołówkiem arabska cyfra: "4". List pisany jest na podwójnej, nieliniowanej kartce formatu zeszytowego. Brak miejsca wystawienia dokumentu. Znak wodny to herb przedstawiający kotwicę w zdobionym otoku, zwieńczony koroną.

a Powyżej niebieską kredką napisano nazwisko „Teodorowicz” i ołówkiem arabską cyfrę: „7”. List pisany jest na podwójnej, nieliniowanej kartce formatu kieszonkowego. Znak wodny przedstawia herb (prawdopodobnie głowy ptaków) oraz napis „Joynson's Parchment”.

187 Niezidentyfikowana bliżej lwowska Ormianka.

188 Papieskie odznaczenie przyznawane osobom świeckim zasłużonym dla Kościoła.

189 Osoba niezidentyfikowana.

a Powyżej obcą ręką niebieską kredką błędnie napisane nazwisko: „Weber”. Na prawo od tego nazwiska, obcą ręką dopisek: „24/3 Abbazia”. List pisany jest na dwóch podwójnych i nieliniowanych kartkach formatu zeszytowego. Znaki wodne przedstawiają w ozdobnym otoku napis: „Myrtle Mill Ivory Paper”. Brak miejsca wystawienia dokumentu i datacji. 
prosząc Cię bardzo, byś do Wiednia pojechał, bo boję się bardzo, że tam niewielu takich będzie, którzy sytuację ogarną. A przy tym mówię Ci to w zaufaniu, boję się Pinińskiego. Dość powiedzieć, że taki Hussarek ${ }^{190}$ był zdziwiony tym, że Piniński tak gwałtownie uderzał w kierunku interesów Kościoła przeciwnym. Wręcz mi powiedział Hussarek, że to szczęście istne, iż na drugim posiedzeniu Pinińskiego nie było, bo nawet by tego nie uchwalono, co jest w obecnym prawnym projekcie. Ciebie się będzie on żenował i miarę utrzyma.

Tu jest czas bardzo ładny i czuję się wybornie. [...] $]^{\mathrm{b}}$, który nawiasem mówiąc zupełnie zarzucił $4[\ldots]^{c}$ każe Ci się kłaniać. Mnóstwo tu Polaków a jeszcze więcej Węgrów, względnie węgierskich żydów. Myślę, że kontent będziesz z naszego jesiennego memoriału w sprawie Benigniego ${ }^{191}$. Można się było na memoriał oburzać, ale strawić go przecie było niepodobieństwem.

Pozdrawiam Cię najserdeczniej jeszcze raz kładąc na serce przyjazd do Wiednia. Piszę także o ile jeszcze zdążę i do innych naszych biskupów. Może Pelczara i Szeptyckiego ściągniesz?

Daj Ci Boże w tym roku jubileuszowym ukoronować go św. Elżbietą ${ }^{192}$ i dobrym zdrowiem odzyskanym. Ad plurimos annos ${ }^{193}$

Twój oddany $\mathrm{Ci}$

Pozmieniałem, jak widzisz, listów kopie, dobrze, że Wałęgi nie ma.

\section{Dokument 59}

Mój Drogi!a

${ }^{190}$ Hussarek von Heinlein Max (1865-1935), dr prawa, od 1892 r. urzędnik Ministerstwa Wyznań i Oświaty, 1893 r. docent prywatny, prawa kościelnego na Uniwersytecie Wiedeńskim, 1895 r. prof. nadzwyczajny, 1900 r. tytularny prof. zwyczajny, 1911-1917 minister Wyznań i Oświaty, od 1918 r. prof. prawa kościelnego na Uniwersytecie Wiedeńskim, 25 VII - 27 X 1918 r. premier. Hussarek von Heinlein Max, w: ÖBL, Bd. 3, herausg. von L. Santifaller, Graz-Köln 1965, s. 16-17.

b Tekst nieczytelny.

c Tekst nieczytelny.

191 Benigni Umberto (1862-1934), włoski duchowny rzymskokatolicki, wykładowca historii Kościoła w rzymskim Seminarium Duchownym, od 1906 r. podsekretarz Kongregacji Nadzwyczajnych Spraw Kościoła, w 1909 r. założył cieszącą się złą sławą organizację Sodalitium Pianum zw. Sapinierą ds. inwigilacji osób podejrzanych o modernizm. Przeciwko jego działalności rozwinęli akcję polscy biskupi galicyjscy, celem usunięcia go z Rzymu. Abp J. Teodorowicz opracował latem 1910 r. memoriał dla papieża i sekretarza Stanu na temat szkodliwej roli Benigniego w Kościele. Duchowny ów utrzymał się wszakże na stanowisku aż do pontyfikatu Benedykta XV (1914-1922), który położył kres Sapinieże, a samego twórcę wydalił z Rzymu. T. Marschler, Umberto Benigni, w: BBKL, Nordhausen 2002, kol. 113-116; informacje własne autora.

192 Abp J. Bilczewski w 1905 r. poświęcił kamień węgielny pod budowę kościoła pw. św. Elżbiety we Lwowie, a w 1911 r. poświęcił gotowy gmach.

193 Łac.: wiele lat życia, sto lat.

a List pisany na 3 stronicach czystego papieru formatu A4. W lewym górnym rogu strony tytułowej obcą ręką napisano ołówkiem: „Teodorowicz”. Brak miejsca wystawienia dokumentu. 
Nie mogłem przybyć do Albano ${ }^{194}$, gdyż właśnie w ten dzień miałem tu dawać 1-szą Komunię, natomiast pozostałem do jutra tu w Rzymie, by bez załatwienia sprawy nie odjechać. Miałem Ci pisać do Nettuno ${ }^{195}$, ale dowiedziawszy się, że przyjeżdżasz dziś wieczór posyłam jednak list, byś jeszcze mógł przez noc rozważyć moje argumentab, a postąpisz jak będziesz uważał.

Otóż nie weźmiesz mi za złe, gdy Ci całkiem szczerze powiem, iż mi się nie wydaje być wskazanym czynić zależnym dalsze kroki od aprobaty wszystkich biskupów; a to z tej przyczyny, że przecie bez nich zaczęliśmy. Dlaczegóż teraz, gdy chodzi o rzecz mniejszą, o konsekwencje naszego pierwszego kroku raptem mamy wszystko na nich zwalać? Czyż nam nie powiedzą słusznie: bez nas zaczęliście, więc i bez nas kończcie. Przy tym sytuacja nie cierpi zwłoki. Trzeba się zdecydować teraz, bo potem być może musztarda po obiedzie.

Bo zastanówmy się na zimno nad sytuacją wytworzoną po rozmowie z M[erry] del $\mathrm{Val}^{196}$. Nie gniewaj się proszę za moją szczerość, ale tak Tobie jak i mnie nie chodzi tu o sprawy osobiste, tylko i jedynie [o] sprawę samą. Otóż Ty wiesz, jak w szczegółach byłem kontent $\mathrm{z}$ toku, nawet Cię ucałowałem później. Tylko jeśli wezmę sytuację w jej całości, to nie my pokonali M[erry] d[el] V[al|, ale on nas.

Jeśli Sobie dobrze uprzytomnisz rozmowę z nim, toś Ty bił głównie na to, że nasze traktowanie sprawy nie jest serio i uzasadniałeś, że nam o tylko jedno chodzi, by wiedzieć, co mamy począć $w$ razie opublikowania dokumentu. Zapewne, że nam i o to chodziło, ale nie jedynie o to. Nam głównie chodziło i zasadniczo o usunięcie Ben[igniego] względnie o dowód nieufności ku niemu. Przez to Twoje stanowisko Merry del Val mógł śmiało sądzić, że nas zupełnie zaspokoił skoro obiecał dać oświadczenie, ale tym samym wypuściliśmy go zupełnie z klatki, co gorsza, mógł powiedzieć papieżowi, że nas obietnicą oświadczenia zupełnie uspokoił. Broń Boże nie czynię Ci tu żadnych wyrzutów, tylko właśnie wykazuję, że sytuacja przez tę rozmowę wytworzona i sposób postawienia kwestii i głównego nacisku na kwestię, domaga się koniecznie zdaniem moim uzupełnienia. Inaczej możemy spowodować, że stan obecny jest jeszcze gorszy niż ten, co był przedtem. Bo Ben[igni] będzie na całej linii tryumfował. Potwierdza mnie w tym to, co mówił mi O. Ledóchowski ${ }^{197}$ o tym, co papież powiedział Jego siostrze ${ }^{198}$ o naszej audiencji To, co dotąd zrobiliśmy,

${ }^{194}$ Albano - miejscowość wypoczynkowa nad jeziorem we Włoszech niedaleko Rzymu.

195 Nettuno - miejscowość k. Anzio nad Adriatykiem.

b Zapis zgodny z oryginałem; poprawnie powinnio być: argumenty.

${ }^{196}$ Merry del Val Rafael (1865-1930), syn hiszpańskiego dyplomaty, święcenia kapłańskie w 1888 r., dyplomata Stolicy Apostolskiej, od 1903 r. kardynał, 1903-1914 sekretarz Stanu; jego nazwisko kojarzy się z epoką walki z modernizmem. N. Miko, Merry del Val Raffaele, w: LThK, Bd. 7, herausg. von J. Höfer, K. Rahner, Freiburg 1962, kol. 312.

197 Ledóchowski Włodzimierz (1866-1942), święcenia kapłańskie w 1894 r. w Zakonie oo. Jezuitów w Krakowie, 1902-1906 prowincjał galicyjski, 1906-1915 asystent asystencji niemieckiej, 1915-1942 generał Zakonu; za jego rządów zakon rozrósł się tak pod względem organizacyjnym, jak i personalnym. Był orędownikiem spraw polskich w Stolicy Apostolskiej. Ledóchowski Wtodzimierz, w: EWJ, s. 357-358.

198 Nie wiadomo, którą siostrę o. W. Ledóchowskiego miał na myśli autor listu; mogła to być bł. Maria Teresa - założycielka Sodalicji św. Piotra Klawera, bądź św. Urszula - założycielka Zgromadzenia Szarych Urszulanek. 
równałoby się więc zeru. Dlatego sądzę, koniecznie potrzeba, moim zdaniem, odrzucone $\mathrm{z}$ memoriału argumenta nie tylko podać, ale jeszcze silniej rozwinąć, a uważam to za tak rzecz niezbędną, że jeśli Ty nie chciałbyś się na to zgodzić, to ja to zrobię od siebie. Nie gniewaj się, proszę Ciebie, za to na mnie, ale nie widzę innego wyjścia z całej sytuacji, która inaczej skończy się katastroficznie, a przy tym naszą kompromitacją.

Oddany $\mathrm{Ci}$ z całego serca

Niedziela, 8/V [1]910

† Teodorowicz

\section{Dokument 60}

\section{Najprzewiełebniejszy Księże Arcybiskupie! ${ }^{\mathrm{a}}$}

Poniedziałek

Właśnie był u mnie O. Ledóchowski i po rozmowie z nim wysyłam ten liścik, by Cię najgoręcej prosić, abyś ze swego Tuskulum ${ }^{199}$ przybył tu na czwartek. Wierzaj mi, że nie ruszalibyśmy Cię za nic, tym bardziej, skoro wiemy jak mało Ci czasu zostaje do dyspozycji, ale kwestia jest nadzwyczaj ważna, zostająca w najściślejszym związku ze sprawą przez nas poruszoną. Dlatego proszę o czwartek, gdyż najpóźniej piątek wieczór muszę wyjeżdżać, a tylko dla tej sprawy zostaję do tego czasu.

Uścisk zasyłam serdeczny

Teodorowicz

\section{Dokument 61}

\section{Mój Drogi! ${ }^{\mathrm{a}}$}

Chętnie się zgadzam, by Amirowicz ${ }^{200}$ pracował przy kościele św. Mikołaja, gdyż u mnie nie ma obecnie żadnego zajęcia, co mu nie może wyjść na dobre. Nie wiem tylko

a Powyżej obcą ręką niebieską kredką napisano nazwisko: „Teodorowicz”. List pisany jest na podwójnej, nieliniowanej kartce formatu kieszonkowego. W prawym górnym rogu napis: „Modern Hotel Roma”. W drugim rogu kartki znajduje się nieczytelny, fragmentaryczny znak wodny. Brak miejsca wystawienia dokumentu i datacji.

199 Właściwie: Tusculum - w starożytności letnia miejscowość wypoczynkowa bogatych Rzymian w Lacjum na pd.-wsch. od Rzymu. Synonim cichego, wiejskiego miejsca odpoczynku dla mieszkańców miasta.

a Powyżej adnotacja ręką abp. Bilczewskiego: „Dla Konsystorza: Ks. Arcybisk[up] Teodorowicz daje na mój list Ks. Amirowicza na wikar[iusza] do kośc[ioła] św. Mikołaja". Obok obcą ręką, niebieską kredką napisano nazwisko: „Teodorowicz”. List pisany jest fioletowym atramentem na podwójnej, nieliniowanej, jasnoniebieskiej kartce formatu zeszytowego. Znak wodny przedstawia napis: „Extra Superfine”.

${ }^{200}$ Amirowicz Kajetan (1881-1965), duchowny ormiańskokatolicki, święcenia kapłańskie w 1906 r., 1906-1907 wikariusz katedry ormiańskiej we Lwowie i dyrektor Zakładu Naukowego im. Torosiewicza tamże, 1907-1910 administrator parafii w Łyścu, od 1910 r. wikariusz parafii łacińskiej pw. św. Mikołaja we Lwowie, a później wikariusz katedry ormiańskiej tamże, 1922-1945 proboszcz w Śniatyniu; kanonik honorowy Kapituły Katedralnej. Po 1945 r. opuścił teren Związku Sowieckiego, osiadając w Żurawicy k. Przemyśla jako rezydent. T. Zaleski, Stownik, s. 25. 
jak to formalnie pogodzić z tym, że obecnie jest wikarym przy katedrze. Chyba niech zrezygnuje, albo może nie potrzeba tej kwestii tykać.

Jeśliby doktor pozwolił, najchętniej Cię odwiedzę, ale prócz tego wypadku gdzieś mnie spotkał po kryjomu idącego do miasta, nie wychodzę wcale, gdyż mi nie chcą na to pozwolić mówiąc, że jestem tak wyczerpany, iż muszę mieć najbezwzględniejszy spokój. W każdym razie może się uda, a tymczasem przejrzę broszury, za które Ci dziękuję.

Gratuluję Ci przy tym prześlicznego przemówienia na otwarciu domu katolickiego ${ }^{201}$. Łączę najoddańsze wyrazy

Lwów, 2/II [1]911

Józef

\section{Dokument 62}

Mój Drogila

Jakbyś przeczuwał, że Ci w ostatniej chwili skrewię. Niestety, po obiedzie rozbrykał mi się mój żołądek tak, że bojąc Ci się zawód możliwy robić jutro, wolę uprzedzić dzisiaj i najmocniej Cię przeprosić za kłopot sprawiony. Jak tylko mi będzie lepiej, odwiedzę Cię $\mathrm{w}$ wolnej chwili. Tymczasem raz jeszcze przepraszając, czego sam najwięcej żałuję, bo mnie omija taka śliczna okazja - ściskam Cię serdecznie

Lwów, 11/II [1]911

Twój Józef

\section{Dokument 63}

Mój Drogi! ${ }^{a}$

Będę Ci służył najpewniej. Co do namiestnika, to nie wiem jeszcze czy będę. O Palmierim ${ }^{202}$ nie piszę, bo tę sprawę musimy omówić. Dziękuję Ci najserdeczniej za

${ }^{201}$ Ceremonii poświęcenia Domu Katolickiego we Lwowie przy ul. Gródeckiej dokonał abp J. Bilczewski 29 I 1911 r. W wygłoszonym wówczas przemówieniu podkreślił, że gmach zbudowała ,jedynie chrześcijańska miłość”, stąd przeznaczeniem instytucji ma być „krzewienie zasad sprawiedliwości, czynnej miłości Boga, bliźniego, Ojczyzny - w jedności wszystkich stanów". Przestrzegał zarazem przed niebezpieczeństwem walk klasowych i nienawiści, a nawoływał, aby „w tej instytucji krzewiła się zawsze gorąca myśl katolicka i polska". J. Bilczewski, Mowa przy otwarciu Domu Katolickiego we Lwowie dn[ia] 29 I 1911, w: tenże, Listy pasterskie, odezwy, kazania i mowy okolicznościowe, t. 2, Lwów 1922, s. 278-282; M. Tarnawski, Arcybiskup, s. 165

a Powyżej obcą ręką błędnie napisane ołówkiem nazwisko: „Weber”. Obok, również ołówkiem, liczba: "18”. List pisany jest na podwójnej, niebieskiej, nieliniowanej kartce formatu zeszytowego fioletowym atramentem. Znak wodny przedstawia napis: „Extra Superfine”.

a Powyżej obcą ręką ołówkiem błędnie napisane nazwisko: „Weber”. Obok liczba: „19”. List pisany jest na podwójnej, nieliniowanej kartce formatu kieszonkowego. W dolnej części kartki widoczny w postaci znaku wodnego napis: „Imperial Mill Extra - Strong B. W.” Brak miejsca wystawienia dokumentu.

${ }^{202}$ Palmieri Aurelio (1870-1926), od 1885 r. augustianin, orientalista, autor 15 poważnych dzieł i ponad 300 artykułów poświęconych problematyce orientalistycznej, m.in.: La Chiesa russa (1908), Theologia 
zawiadomienie mnie o wiecu w Krakowie i podanie mi tekstu Waszego telegramu. Tylko tak wyjąłeś mi w tym telegramie wszystko, że musiałem kołować i objeżdżać tak, że na dobrą sprawę winieneś mi restytucję za długi telegram.

Najserdeczniej Cię pozdrawiam

Józef

Może jeszcze i pojadę do Jeruzalem. Dziś ma być Wiczkowski ${ }^{203}$ i tę sprawę ostatecznie rozstrzygnie.

Niedziela, 19/II [1]911

\section{Dokument 64}

Mój Drogi!a

Abbacja, d[nia] 29/II [1]911

Bardzo mnie zmartwił Twój telegram o zdrowiu. Choć mało mam nadziei byś posłuchał mej rady, bardzo Cię zachęcam byś się gwałtem oderwał na parę tygodni ze Lwowa i tu przyjechał. Święta Cię jeszcze więcej przemęczą, a tu zaczął się czas prześliczny. Na to potrzeba się nie namyślać, tylko zebrać się i w świat. 2-go przyjeżdża tu Dr Szulisławski"

dogmatica ortodoxa. Prolegomena (t. 1-2, 1913). Wydawał też czasopismo „Bessarione” i był dyrektorem Instytutu Orientalistycznego. Osoba i publikacje Palmieriego szczególnie bulwersowały biskupów łacińskich i arcybiskupa ormiańskiego w Galicji, bowiem wykazywały one tendencyjne sympatie ku unitom i abp. Szeptyckiemu. Niezwykłe oburzenie wywołała jego broszura Mohlianismus et Panpolonismus z 1911 r., uznana przez abp. Bilczewskiego za „najohyd[niejszy] paszkwil”. Zawarte w niej tezy sugerowały, że prawie wszyscy Polacy uważali katolicyzm jedynie za środek wiodący do realizacji celów narodowych. Lwowski metropolita łaciński pisał: „Nie wchodzę w szczegóły broszury - w niejednym przypadku autor ma może i słuszność - całość i tendencja jest ohydna - Kościołowi szkodliwa. Takiego człowieka Szeptycki, b[yły] Polak, nie powinien przepuścić nawet przez próg swojego domu". Ponadto abp Bilczewski miał dowody na ścisłe kontakty łączące Palmieriego z abp. Szeptyckim, któremu ten ostatni finansował druk publikacji. AALK, bsygn., J. Bilczewski, Dziennik, s. 81, 85-87; R. Janin, Palmieri Aurelio, w: LThK, Bd. 8, herausg. von J. Höfer, K. Rahner, Freiburg 1986, kol. 13-14.

203 Wiczkowski Józef (1858-1924), dr wszechnauk lekarskich 1883 r., asystent przy Katedrze Chemii Lekarskiej UJ, od 1886 r. pracował we Lwowie, w 1898 r. habilitował się na Uniwersytecie Lwowskim, był docentem patologii specjalnej i terapii chorób wewnętrznych, od 1906 r. prof. nadzwyczajny Wydziału Lekarskiego Uniwersytetu Lwowskiego; 1887-1900 kierownik pracowni chemicznej przy Szpitalu Powszechnym we Lwowie, 1900-1924 prymariusz Oddziału Chorób Wewnętrznych tegoż szpitala. Położył wielkie zasługi na polu walki z gruźlicą, zorganizował i prowadził Towarzystwo Przeciwgruźlicze i założył sanatorium dla gruźlików w Hołosku k. Lwowa. Kronika Uniwersytetu Jana Kazimierza we Lwowie za rok szkolny 1924/25 stanowiaca sprawozdanie rektora i dziekanów, zestawit rektor w roku szkolnym 1924/25 prof. dr Wtodzimierz Sieradzki, Lwów 1925, s. 3-4; W. Wojtkiewicz-Rok, Wydziat Lekarski, w: Academia militans. Uniwersytet Jana Kazimierza we Lwowie, red. A. Redzik, Kraków 2015, s. 154, 798, 837-838,

a Obok daty, obcą ręką błędnie napisano ołówkiem nazwisko: „Weber”. List pisany jest na podwójnej, nieliniowanej kartce formatu zeszytowego. Znak wodny przedstawia napis: „Myrtle Mill Extra Strong” oraz herb $\mathrm{z}$ monogramem na polu tarczowym.

${ }^{204}$ Szulisławski Adam (1865-1911), dr wszechnauk lekarskich UJ, od 1895 r. ordynator Oddziału Ocznego Polikliniki Powszechnej we Lwowie, docent prywatny Uniwersytetu Lwowskiego, w 1909 r. prof. nadzwyczajny. W. Wojtkiewicz-Rok, Wydziat Lekarski, s. 798, 852, 855. 
mógłbyś więc z nim przybyć. Niech tam Bandurski ${ }^{205}$ nas ze Święconym zastępuje, albo też i on może zastrajkować.

Ja też we Wiedniu być nie mogłem. Czekam rezultatu. Jeszcze raz proszę, weź sobie do serca radę. Ściskam Cię i pozdrawiam najserdeczniej.

Oddany $\mathrm{Ci}$

Józef

\section{Dokument 65}

Żałuja żeś nie pojechał. Spod stóp piramid ślę Ci serdeczne pozdrowienia ${ }^{206}$.

Twój Józef

\section{Dokument 66}

Kochany Księże Arcybiskupie!

Dziękuję Ci za telegramy. Byłem poważnie zaniepokojony o B[andurskiego], zwłaszcza wobec wiadomości, jakie otrzymywał Warszelewicz ${ }^{207}$ ze Lwowa. Dziś kryzys minął, a i powoli zacznie się rekonwalescencja, widocznie długa skoro sądzisz, że nie będzie

${ }^{205}$ Bandurski Władysław (1865-1932), święcenia kapłańskie w 1887 r. we Lwowie, dr teologii, 1889-1893 wikariusz w Kamionce Strumiłłowej, 1893-1895 wikariusz w katedrze lwowskiej, 1895-1896 sekretarz bp. Jana Puzyny w Krakowie, 1896-1906 kanclerz Kurii Biskupiej tamże, od 1899 r. kanonik Kapituły Katedralnej. Dnia 26 IX 1906 r. prekonizowany biskupem pomocniczym archidiec. lwowskiej: wikariusz generalny i rektor Seminarium Duchownego, działacz patriotyczno-społeczny. Po wybuchu I wojny światowej udał się do Krakowa, a stamtąd do Wiednia. Wskutek oskarżeń o nadużycia natury moralnej został zmuszony przez episkopat rzymskokatolicki Galicji do rezygnacji z funkcji biskupa pomocniczego, 16 IV 1917 r. otrzymał stosowny dekret Stolicy Apostolskiej. Po 1918 r. osiadł w Wilnie; był duszpasterzem Legionów, generałem dywizji, autorem licznych publikacji religijno-patriotycznych. AALK, bsygn., J. Bilczewski, Dziennik, passim; AALK, bsygn., Kopia pisma abp. J. Bilczewskiego do ministra Ludwika Ćwiklińskiego, Lwów 29 III 1918 r., teczka: Korespondencja abp. J. Bilczewskiego; S. Rachwał, Ks. biskup dr Wtadystaw Bandurski. Wzór kapłana-Polaka, Lwów 1913, passim; W. J. Wysocki, A. C. Żak, Biskup Władystaw Bandurski, Pruszków 1997, passim.

a Karta pocztowa. Na awersie kartka przedstawia piramidy przy zachodzącym słońcu. Na rewersie, oprócz pozdrowień, adres: „Autriche - Galicie via Wien, Excellenz Erzbischof Bilczewski, Lemberg”. W prawym górnym rogu 2 znaczki, na których przybito stempel w języku arabskim z czytelnym napisem: „Continental Cairo". Brak miejsca wystawienia dokumentu i datacji.

${ }^{206}$ W 1911 r. abp J. Teodorowicz w towarzystwie sekretarza i kapelana ks. Franciszka Komusiewicza odbył pielgrzymkę do Ziemi Świętej. S. Gawlik, Życie i działalność, s. 22.

a List pisany jest na pojedynczej, nieliniowanej kartce formatu zbliżonego do A4. Znak wodny przedstawia zdobiony napis: „Original Special Bank 1090”.

207 Właściwie: Warszylewicz Albin (1872-1941), święcenia kapłańskie w 1897 r. we Lwowie, dr teologii, 1901-1905 sekretarz i kapelan abp. J. Bilczewskiego, 1905-1913 ojciec duchowny Seminarium Duchownego we Lwowie, kanonik gremialny Kapituły Metropolitalnej, wizytator szkół średnich, sędzia i egzaminator synodalny, prałat domowy papieski, odznaczony Złotym Krzyżem Zasługi. Schematismus [...] 1897-1941, passim. 
mógł mieć skargowskiego kazania ${ }^{208}$. Ale to znowu dla mnie pensum $^{209}$ prawie nie do wykonania, bo mam w Krakowie mieć kazanie. 2 osobne kazania są mi iście niepodobne zwłaszcza, że dotąd nie tylko nie mam kazania skargowskiego, ale nawet przemowy na Wiedeń, w którą najniepotrzebniej dałem się wpakować komitetowi ${ }^{210}$. Więc istotnie i chciałbym Ci wygodzić, i znowu nie wiem jak z tego wybrnaćc?

Co do Band[urskiego]: podowiadywałem się rzeczy niestety bardzo poważnych, które mu zgubę mogą wróżyć. Jest to dziś już skonstatowaną rzeczą, że go wplątali ludzie nie już z narodowych partii, ale wprost rewolucyjnych. Trzeba go ratować, no i naturalnie trzeba ratować Kościół i społeczeństwo. To bardzo niebezpieczne. Ale o tym rozmówię się z Tobą we Wiedniu. Wiedziałem, że mu rozmowy nie zdradzisz, ale myślałem żeś może coś wypowiedział, co go na domysł naprowadzało, a wnosiłem stąd, że mi na telegram z gratulacjami nie dał odpowiedzi. Dziękuję Ci więc za uspokojenie w tej mierze. Na mnie możesz zupełnie w tej sprawie liczyć, uważam ją w tej chwili za najgroźniejsze, a w skutkach najniebezpieczniejsze dla nas niebezpieczeństwo. Wtedy we Lwowie opierałem się na domysłach, ale dziś mam w ręku fakta.

Tymczasem najserdeczniejsze i najoddańsze ślę Ci wyrazy

Tu śliczny czas, zostanę już do kongresu ${ }^{211}$.

Abbacja, villa Augusta, 21/VIIII [1]911

\section{Dokument 67}

\section{Mój Drogi! ${ }^{a}$}

Widzę, że musi być jakieś nieporozumienie w całej sprawie; bo ja od pierwszego razu powiedziałem, że nie mogę dać Kunzego ${ }^{212}$ przeznaczywszy go gdzie indziej - więc mylnie mówi proboszcz, że się cofałem. Teraz prosiły zakonnice, by go dać na krótki czas. Otóż na to odpowiedziałem, że pod tym względem muszę się porozumieć z proboszczem. Jeśli atoli Ty chcesz, to nie mogę rzecz naturalna Ci odmówić. Mogę go tedy dać,

${ }^{208}$ Zjazd Skargowski odbył się w Krakowie w 1912 r. z okazji 300. rocznicy śmierci ks. Piotra Skargi.

209 Łac.: praca, zadanie.

${ }^{210}$ W dniach 11-15 IX 1912 r. w Wiedniu odbył się XXIII Kongres Eucharystyczny.

${ }^{211}$ Autor nawiązuje do organizowanego przez bp. Józefa Sebastiana Pelczara Kongresu Mariologicznego w Przemyślu w dn. 26-28 VIII 1911 r., który istotnie się odbył.

a Powyżej obcą ręką ołówkiem błędnie napisano nazwisko: „Weber” (przekreślone). Ponadto ołówkiem dopisano obok liczbę: „26”. List pisany jest na podwójnej, nieliniowanej kartce formatu zeszytowego. Znak wodny przedstawia dwie końcówki wyrazów „[...] Good's [...]ine”. Brak miejsca wystawienia dokumentu.

212 Właściwie: Kuntze Tadeusz (1888-1959), święcenia kapłańskie w 1911 r. we Lwowie w obrządku ormiańskokatolickim, 1911-1914 wikariusz parafii łacińskiej w Sokołówce k. Świrża, 1914-1945 wikariusz katedry ormiańskiej we Lwowie i katecheta szkół podstawowych tamże. W 1945 r. w ramach ekspatriacji udał się na Dolny Śląsk, inkardynując się do archidiec. wrocławskiej: 1945-1946 kapelan szpitala św. Anny i katecheta we Wrocławiu, 1946-1952 wikariusz parafii pw. św. Henryka i Świętego Ducha tamże, 19521953 kapelan kliniki uniwersyteckiej i pomocnik duszpasterza we Wrocławiu-Leśnicy, od 1953 r. emeryt. T. Zaleski, Stownik, s. 67-68. 
ale z zastrzeżeniem, że gdy go tylko zapotrzebuję, wolno mi będzie znowu go zarekwirować. Jeśli Ci w takich warunkach to dogadza to służę.

Najserdeczniej oddany

Józef

26/VIII [1]911

\section{Dokument 68}

\section{Carissime ?13 $^{13}$}

Przepraszam ${ }^{a}$ Cię, że tak dorywczo piszę, ale jestem wprost przerażony wiadomością, że Daszyński ma zostać prezesem kola polskiego ${ }^{214}$. Zaciekłość partyjna krakowskich panów gotowa i do tego dopuścić. Pomyśleć sobie, co to za następstwa fatalne! Jak staje wtedy Polska wobec Rzymu. Jak staje wobec świata katolickiego? Jaki to wpływ na wzrost socjalizmu w kraju i jaki wpływ na rozrost socjalizmu w Królestwie. Sądzę, że powinniście się z Sapiehą wziąć do dzieła. Przede wszystkim rozmówić się z Lubomirskim $^{215}$; on jest marionetką $\mathrm{w}$ rękach Jaworskiego ${ }^{216}$. Powiedzieć tym panom, że ich za wszystko odpowiedzialnym się uczyni. Czy by nie należa[ło] natychmiast porozumieć

${ }^{213}$ Łac.: najdroższy.

a Powyżej obcą ręką niebieską kredką napisano nazwisko: „Teodorowicz”. List pisany jest na pojedynczej, nieliniowanej kartce formatu zbliżonego do A4. Brak znaku wodnego.

${ }^{214}$ Koło Polskie - zrzeszenie polskich posłów w parlamencie austriackim, funkcjonujące w l. 1861-1918. W myśl regulaminu wybierano prezesa i wiceprezesa, a w parlamentarnych wystąpieniach - z wyjątkiem kwestii religijnych - obowiązywała zasada solidarności. W szeregach Koła znajdowali się polscy posłowie z Galicji oraz Śląska Cieszyńskiego, jak również wybierani w Galicji reprezentanci społeczności ukraińskiej i żydowskiej; nie należeli doń członkowie Izby Panów, ale uzgadniali z nim linię polityczną. Pierwszym prezesem Koła był Kazimierz Grocholski. Do 1907 r. przewagę w Kole posiadali konserwatyści (stańczycy i podolacy); w jego szeregach byli też liberalni demokraci, od początku zaś XX w. także narodowi demokraci, po 1901 r. przystąpiła część posłów chrześcijańsko-ludowych, w 1908 r. akces zgłosili ludowcy, w 1916 r. socjaliści. Ogółem Koło liczyło 30-70 posłów. Po okresowej opozycji względem centralistycznej polityki Wiednia, od 1867 r. Koło okazywało aktywne wsparcie rządowi wiedeńskiemu; odegrało też ważną rolę w powstaniu Legionów Polskich i Naczelnego Komitetu Narodowego. P. Matusik, Koło Polskie, w: EK, t. 9, red. zbior., Lublin 2002, kol. 421.

${ }^{215}$ Lubomirski Andrzej (1862-1953), dr praw, 1882-1939 kurator literacki Zakładu Narodowego im. Ossolińskich we Lwowie, 1898-1914 poseł do Sejmu Galicyjskiego; należał do politycznych przeciwników Michała Bobrzyńskiego, 1907-1918 poseł do Rady Państwa, od 1887 r. był dziedzicznym członkiem Izby Rady Państwa. W 1914 r. wstąpił do Naczelnego Komitetu Narodowego jako przedstawiciel konserwatystów wschodniogalicyjskich. Po 1945 r. emigrował do Brazylii, gdzie zmarł. M. Tyrowicz, J. Zdrada, Lubomirski Andrzej, w: PSB, t. 18, red. zbior., Wrocław 1973, s. 4-6.

${ }^{216}$ Jaworski Władysław Leopold (1865-1930), dr praw, habilitował się w 1895 r. na UJ, w 1897 r. został prof. i kierownikiem Katedry Prawa Cywilnego UJ; od 1905 r. związany ze stronnictwem stańczyków krakowskich, 1901-1913 poseł do Sejmu Galicyjskiego, 1911-1918 poseł do Rady Państwa. Był współtwórcą idei zbliżenia konserwatystów z ludowcami; od 1900 r. redaktor krakowskiego „Czasu”, członek NKN. Wyznawał koncepcję austro-polskiego rozwiązania kwestii polskiej, ale w ramach federacji środkowoeuropejskiej pod hegemonią Niemiec. Był autorem prac naukowych z dziedziny prawa administracyjnego i cywilnego. J. Buszko, Jaworski Wtadystaw Leopold, w: PSB, t. 11, red. zbior., Wrocław-Warszawa-Kraków 1964, s. 115-118. 
się z Sapiehą? Tu każda chwila droga, więc działanie niezwłoczne konieczne. Zdaje się w sobotę powrócę. Nie zazdroszczę Ci tych dni. Tu ślicznie jest, aż żal się stąd wybierać.

Ściskam Cię serdecznie

Ten ksiądz z Niżniowa ${ }^{217}$ to bardzo zacny i dobry kapłan.

Twój [Józef]

Wtorek, 5/IX [1]911

\section{Dokument 69}

Carissime $^{\text {! }}$

Zgadzam się, bo nie można inaczej istotnie. Osobno zapraszać mnie nie ma potrzeby. Serdecznie ściskam i pozdrawiam

† Józef

16 X $[1] 911$

\section{Dokument 70}

$W^{a}$ tej chwili prosi mnie moja diecezjanka o pozwolenie odprawienia Mszy Św. w jej domu dla chorej osoby, która należy do Ciebie. Wobec tego proszę Cię, byś raczył zezwolenie to dać. Najserdeczniej pozdrawiam.

Niedziela, 24/XII [1]911

\section{Dokument 71}

$1 / \mathrm{II}[1] 912$

Najuprzejmiej ${ }^{a}$ Ci dziękuję za list i obietnicę odwiedzenia mnie, i będzie mi nad wyraz miło Cię powitać.

Najoddańszy

Józef

${ }^{217}$ Niżniów - miasteczko w pow. Tłumacz, woj. Stanisławów.

a List pisany na jednej stronicy nieliniowanego papieru formatu kieszonkowego. Brak miejsca wystawienia dokumentu.

a Tekst zapisany jest na odwrotnej stronie wizytówki z nadrukiem: „Arcybiskup Teodorowicz”. Brak miejsca wystawienia dokumentu.

a List pisany jest na sztywnej, pojedynczej, nieliniowanej kartce formatu kieszonkowego. Brak tytulatury i miejsca wystawienia dokumentu. W górnej części strony tytułowej obcą ręką niebieską kredką napisano nazwisko: „Teodorowicz”. 


\section{Dokument 72}

Carissime $^{\text {a }}$

Serdecznie dziękuję Ci za ofiarę. Telegrafował mi w tej sprawie nuncjusz. Jeśliby więc ta krakowska ofiara była przypadkiem obiecana mi przez nuncjusza, to bym Cię ewentualnie prosił o zarezerwowanie mi całej mej porcji.

Jak się miewasz? Biedny Rutowski ${ }^{218}$ miał 2 ataki apoplektyczne i stan jego jest groźny. Na jutro zgłosiły do mnie 2 panie katolickie. Sapieha pisze, byśmy się po świętach zjechali.

Ściskam serdecznie

Środa, 4/IV [1]912

† Józef

\section{Dokument 73}

Kochany Księże Arcybiskupie!

Dziękuję Ci najserdeczniej za troskę o zdrowie, które jest na zupełnie dobrej drodze. Co do kongresu ${ }^{219}$, opowiem dokładnie ustnie. W każdym razie wstępna cała akcja jest zaaranżowana. Trudność będzie z przełożoną Komitetu Lwowskiego. Ale to do omówienia ustnego.

Jeszcze raz najserdeczniej Ci dziękuję i najoddańsze łączę wyrazy

W sobotę będę u Ciebie.

Teodorowicz

Kraków, d[nia] 4/IV [1]912

a Powyżej obcą ręką błędnie napisano nazwisko: „Weber”. Brak miejsca wystawienia dokumentu.

${ }^{218}$ Rutowski Tadeusz (1852-1918), dr filozofii, od 1882 r. redaktor odpowiedzialny „Reformy” („Nowej Reformy”) w Krakowie. W 1884 r. przeniósł się do Lwowa pracując w Wydziale Krajowym, 1887-1901 poseł do Rady Państwa, 1889-1895 i od 1901 r. poseł do Sejmu Galicyjskiego, 1896-1902 redaktor „Słowa Polskiego", od 1902 r. członek Rady Miejskiej Lwowa, 1905-1917 wiceprezydent Lwowa; wywieziony przez wojska rosyjskie przebywał w l. 1915-1917 w Kijowie, Rostowie n. Donem i Piotrogrodzie, 1917-1918 komisarz rządowy Lwowa. Zasłużył się dla życia artystycznego miasta: dbał o dotacje dla muzeów, wzbogacał ich zbiory nabytkami, popierał twórców krajowych. S. Kieniewicz, Rutowski Tadeusz, w: PSB, t. 33, red. zbior., Wrocław-Warszawa-Kraków 1991-1992, s. 252-256.

a Powyżej napisy: niebieską kredką nazwisko „Teodorowicz”, a ołówkiem cyfra „1”. List pisany jest na podwójnej, nieliniowanej kartce formatu zeszytowego. Brak znaku wodnego.

${ }^{219}$ XXIII Kongres Eucharystyczny w Wiedniu (11-15 IX 1912 r.). 


\section{Dokument 74}

Chciałem $^{a}$ wysłać z tym listem do Ciebie Twego sekretarza. Dowiedziawszy się jednak, że dopiero pod wieczór przybyć może do Ciebie i że dziś telegram do Pelczara niemożliwy, wysłałem już sam na własną rękę do niego telegram podpisując: Josephus. Tak nie będzie on wiedział, czy to ode mnie, czy od Ciebie. Prócz tego jeszcze telegrafuję do Ciebie na wypadek gdyby list się spóźnił o terminie konferencjii ${ }^{220}$.

\section{Dokument 75}

\section{Carissime $^{\text {!a }}$}

Chciałem Cię prosić dziś do siebie na poufną rozmowę, w której wezmą udział Czartoryskii ${ }^{221}$, Cieński ${ }^{222}$ i profesor Jentys ${ }^{223}$. Dowiedziałem się niestety, że masz o 5 -tej procesję, Czartoryski zaś dłużej czekać nie może. Będzie u Ciebie dziś Jentys i jeślibyś mógł być o wpół do czwartej u mnie, byłoby bardzo pożądane. Daj odpowiedź przez Jentysa. Serdecznie Cię pozdrawiam, Twój

Teodor[owicz]

9/IV [1]912

a List pisany na pojedynczej, niebieskiej nieliniowanej kartce papieru formatu zeszytowego. Brak tytulatury, datacji i autografu autora pisma. Poniżej tekstu dopisek ręką abp. Bilczewskiego: „dodatek do listu wysłanego do Wyżnian. 27.4".

${ }^{220}$ Konferencja biskupów rzymskokatolickich Galicji z udziałem abp. Teodorowicza odbyła się 29 IV 1912 r. we Lwowie, a po południu tegoż dnia została przeniesiona do rezydencji greckokatolickiego bp. Grzegorza Chomyszyna w Stanisławowie. W części pierwszej omawiano sprawę Kongresu Eucharystycznego w Wiedniu, opieki nad polskimi emigrantami w Bośni, kandydatury na urząd rektora Hospicjum Polskiego w Rzymie. W drugiej części zajęto się w dalszym ciągu problematyką kongresową, dyskutowano o metodach obchodu rocznicy edyktu mediolańskiego oraz podjęto kwestię konserwacji zabytków. AALK, bsygn., J. Bilczewski, Dziennik, s. 204.

a List pisany na 1 stronicy czystego papieru formatu zeszytowego. W lewym górnym rogu karty obcą ręką niebieską kredką napisano: „Teodorowicz”. Brak miejsca wystawienia dokumentu.

${ }^{221}$ Czartoryski Witold (1864-1945), książę, właściciel Pełkiń, Woli Pełkińskiej i Wierzbnej; od 1908 r. poseł do Sejmu Galicyjskiego, członek wiedeńskiej Izby Panów, od 1914 r. należał do NKN, w 1917 r. członek założyciel Komitetu Narodowego Polskiego w Paryżu. Od 1928 r. należał do prezydium Rady Naczelnej i Komitetu Politycznego Stronnictwa Narodowego, senator I kadencji i zastępca senatora II kadencji. Czartoryski Witold, w: Kto byt kim, s. 503.

${ }^{222}$ Cieński Tadeusz (1856-1925), ziemianin, poseł do Sejmu Galicyjskiego, prezes „Sokoła”, prezes Rady Narodowej w Małopolsce. W 1914 r. przewodniczył Centralnemu Komitetowi Narodowemu we Lwowie, prezes sekcji wschodniej NKN, współzałożyciel biur organizacji narodowych we Francji, Anglii, Włoszech i Szwajcarii, uczestnik obrony Lwowa podczas wojny ukraińsko-polskiej 1918-1919 r., senator I kadencji z woj. tarnopolskiego. Cieński Tadeusz, w: Kto byt kim, s. 502.

${ }^{223}$ Jentys Stefan (1860-1919), dr filozofii, fizjolog roślin, chemik rolny i agronom, w 1889 r. prof. Wyższej Szkoły Rolnej w Dublanach, od 1894 r. docent chemii rolnej i rolnictwa UJ, od 1899 r. prof. tamże. Podczas I wojny światowej pracował w KBK, był też współtwórcą Zjednoczenia Narodowego, przeciwnikiem NKN i Legionów. W październiku 1918 r. wyjechał do Lwowa na Ogólny Zjazd Zjednoczenia Narodowego; uczestniczył w rokowaniach polsko-ukraińskich podczas trwającej wojny. F. Górski. Jentys Stefan, w: $P S B$, t. 11, red. zbior., Wrocław 1964-1965, s. 173-174. 


\section{Dokument 76}

Mój drogi Księże Arcybiskupie!

13/IV [1]912

Zgadzam się na pozostanie tam Ks. Kunzego; tylko nie zużywając go dzisiaj już musiałbym go Ci zostawić tak długo aż tu się nie utworzy nowe miejsce dla niego. Więc w każdym razie przez lato zostawiam, a potem obaczymy. Tam go zresztą tak polubili, że tak łatwo nie puszczą.

Ściskam Cię serdecznie

Twój J[ózef]

\section{Dokument 77}

\section{Carissime!}

Kissingen Dr Dapper's Sanatorium ${ }^{\mathrm{a}}$

Posyłam Ci wycinek z „Colner Zeitung”224, wielkiego półurzędowego organu. Przedtem, nim się manifest pokazał w polskich gazetach, już widocznie pruski konsul we Lwowie telegrafował do dziennika swego. Obawy nasze nie były więc płonne. Jeszcze oczywiście trzeba znać tekst polski. W każdym jednak razie jesteśmy zaskoczeni manifestem, pod którego znakiem i tonem my dziś wszyscy.

$\mathrm{Z}$ Bandurskim niestety nie mogłem się był widzieć. Wybieram się rozmówić z nim o tych rzeczach jasno i lojalnie, naturalnie tylko od siebie, napisz mi tylko wprzód proszę czyś mu nie wspomniał przypadkowo o czymś, albo nie powiedział czegoś, co by go naprowadziło na domysł naszej rozmowy ${ }^{225}$.

Jeśli istotnie ten manifest jest taki, jak piszą niemieckie gazety, to jesteśmy naprawdę w bardzo trudnym położeniu. W takim razie radzić co robić, choć Bogiem a prawdą jest już trochę za późno.

a List pisany jest na tekturce formatu wizytówkowego. Brak miejsca wystawienia dokumentu.

a Powyżej ręką abp. Bilczewskiego ołówkiem dopisek: „koło 15.8”. List pisany jest na pojedynczej, nieliniowanej kartce formatu zbliżonego do A4. Znak wodny przedstawia napis: „Original Margaret Mill Theyer \& Harotmuth Wien". Brak miejsca wystawienia dokumentu i datacji.

${ }^{224}$ Właściwie: „Kölner Zeitung” - czasopismo niemieckie wychodzące w 1. 1802-1945.

${ }^{225}$ Zarówno abp Bilczewski, jak i abp Teodorowicz mieli za złe bp. Bandurskiemu jego zaangażowanie się w akcje patriotyczne. Łaciński metropolita lwowski zanotował w podręcznym dzienniku przebieg spotkania z hierarchą ormiańskim 12 VI 1912 r.: „Zeszła rozmowa na hałaśliwą działalność Ks. Bandurskiego mówiliśmy, co byśmy przy nim mówić mogli i powinni. Doszliśmy do wniosku, że jego akcja, w której wciąż prawi o dąż [eniu] do Polski niepodległej jest w najwyż[szym] stopniu szkodliwa dla Kościoła i narodu, bo podnieca, potęguje dzisiejsze podniecenie patriotyczne - szkodzi nam w Rosji, Prusiech, Wiedniu, Rzymie. Jest to chorobliwe szukanie popularn[ości] dla popularn[ości]. Jesteśmy zdania, że trzeba usilnie pracować, żebyśmy Polskę wolną mieli, a mało gadać. [...]. Pomówimy obaj na serio z Ks. Band[urskim], zwrócimy uwagę na nieszczęście, jakie narodowi i sobie gotuje przez to, że szuka nieśmiertelności na łamach dzienników, miast jej szukać w historii, a więcej jeszcze u P[ana] Boga”. AALK, bsygn., J. Bilczewski, Dziennik, s. 218. 
Zwracam też Twą uwagę na notatkę „Słowa” o wiecu eryteryków w Kossowie. Są to panteiści, którzy mają założyć pod Krakowem szkołę.

Proszę o mym liście dzisiejszym nic nie wspominać z łatwo zrozumianych powodów. Do Kochawiny ${ }^{226}$ nie będę mógł przybyć, mimo danej obietnicy. Życzę Ci najlepszych skutków kuracji.

Oddany $\mathrm{Ci}$

J[ózef] T[eodorowicz]

\section{Dokument 78}

Kochany Księże Arcybiskupie! ${ }^{\mathrm{a}}$

[Abbacja], 21/VIII [1]912

Jeszcze drugi list puszczam. Oto z Wiednia dostałem (niestety, dopiero teraz) wezwanie, by się postarać, aby na kongresie była też deputacja uniwersytetu i by był sejm reprezentowany ${ }^{227}$. Byłoby to istotnie bardzo pożądane. Uniwersytetowi można wmówić wzgląd na sprawę ruską, a na marszałka ${ }^{228}$ nacisnąć należy, by przybył z deputacją. Mówił mi Starzyński ${ }^{229}$, że to jest w kompetencji marszałka. Otóż racz się tym zająć. Oni to dla Ciebie zrobią. Jako curiosum ${ }^{230} \mathrm{Ci}$ dopisuję, że tu do Abbacji Wysłouch ${ }^{231}$ telegra- $^{-}$ fował o zdrowie Bandur[skiego].

Najserdeczniej oddany

J[ózef Teodorowicz]

${ }^{226}$ Dnia 15 VIII 1912 r. na terenie archidiec. lwowskiej w Kochawinie k. Stryja odbyła się koronacja łaskami słynącego obrazu Matki Bożej. Uczestniczył w niej galicyjski episkopat łaciński.

a List pisany jest na podwójnej, nieliniowanej kartce formatu zeszytowego. Znak wodny przedstawia napis: „Mary Mill Extra Durable”. Brak miejsca wystawienia dokumentu.

${ }^{227}$ Przygotowania do wysłania na Kongres Eucharystyczny w Wiedniu delegacji Uniwersytetu Lwowskiego i Sejmu Galicyjskiego.

${ }^{228}$ Funkcję ówczesnego marszałka Sejmu Galicyjskiego pełnił w latach 1908-1913 Stanisław Marcin Badeni.

${ }^{229}$ Starzyński Stanisław (1853-1935), dr praw, 1876-1879 urzędnik Namiestnictwa we Lwowie, w 1879 r. pracownik Starostwa w Tarnowie, 1884-1888 i 1901 poseł do Rady Państwa, 1907 r. poseł do Sejmu Galicyjskiego, w 1882 r. habilitacja na Uniwersytecie Lwowskim, 1883-1889 docent austriackiego prawa politycznego tamże, 1889 r. prof. nadzwyczajny, 1892 r. prof. zwyczajny, w roku akad. 1895/96, 1916/17, 1918/19 dziekan, 1896/97 prodziekan Wydziału Prawa i Umiejętności Politycznych, 1913/14 rektor, 1914/15 prorektor uczelni. S. Starzyński, Historia Uniwersytetu Lwowskiego, cz. 2: 1869-1894, Lwów 1894, s. 211-216; Uniwersytet Jana Kazimierza we Lwowie. Sktad uniwersytetu w latach akademickich 1930/1931 i 1931/1932, Lwów 1931, s. 89-90; Uniwersytet Jana Kazimierza we Lwowie. Skład uniwersytetu w latach akademickich 1936/1937 i 1937/1938, Lwów 1937, s. 86; A. Redzik, Wydziat Prawa, w: Academia militans, passim.

${ }^{230}$ Łac.: osobliwość, fenomen.

231 Wysłouch Bolesław (1855-1937), działacz ruchu ludowego, od 1885 r. związany ze Lwowem, gdzie wydawał od 1886 r. „Przegląd Społeczny”; był współzałożycielem i redaktorem naczelnym „Kuriera Lwowskiego", od 1889 r. wydawał i redagował "Przyjaciela Ludu”. Z jego inspiracji powstało w 1895 r. Stronnictwo Ludowe (od 1903 r. PSL). W 1914 r. związał się z PSL „Piast”, a w 1923 r. z PSL „Wyzwolenie”; w 1925 r. wystąpił ze stronnictwa i przeszedł do Klubu Pracy. Wysłouch Bolesław, w: Kto byt kim, s. 560-561. 


\section{Dokument 79}

\section{Carissime $^{\text {Ia }^{2}}$}

Istotnie bardzo by nam było potrzeba się zjechać, tylko mi piszesz, że mają dopiero zamiar napisać do nas, więc i tak potrzeba przeczekać zanim napiszą i zanim się będzie można zorientować o co im idzie. Wobec tego dosiedzę sobie tu jeszcze kilka dni, bo czas tu darowany każdy dzień. Widzę, że się zwijasz co się zowie, tylko nie za wiele naraz, bo zdrowie potrzeba szanować.

Serdecznie Cię ściskam

Truskawiec $^{232}$, 5/IX [1]912

Twój Józef

\section{Dokument 80}

Carissime $^{\text {a }}$

Sobota, 8/XI [1]912

Przybył Sapieha ${ }^{233} \mathrm{z}$ Wiednia, proszę Cię więc byś był u niego dziś około $12 \mathrm{w}$ południe - możliwie incognito ${ }^{234}$.

Najoddańszy

Może wezwiesz zaraz Pelczara telegraficznie?

J[ózef] T[eodorowicz]

\section{Dokument 81}

\section{Najprzewielebniejszy Księże Arcybiskupie! ${ }^{\text {a }}$}

Posyłam Ci odezwę, którą zmień i popraw wedle swego rozumienia. Zdaje mi się jednak, że należy bardzo silnie podkreślić zasadę.

Przy tej sposobności proszę Cię byś cofnął łaskawie Tomaszewskiemu ${ }^{235}$ dane pozwolenie; nie wspominaj mu jednak o mnie, tylko może powołaj się na to, co i mnie mówiłeś,

a Powyżej obcą ręką niebieską kredką błędnie napisano nazwisko: „Weber”. List pisany jest na podwójnej, nieliniowanej kartce formatu kieszonkowego. Znak wodny przedstawia w zdobionym otoku napis: „Ivory Paper”.

${ }^{232}$ Truskawiec - popularny kurort w pow. Drohobycz, woj. Lwów.

a Tekst zapisany jest na sztywnej, pojedynczej, nieliniowanej kartce formatu kieszonkowego. Brak miejsca wystawienia dokumentu.

${ }^{233}$ Bp Adam Stefan Sapieha - rządca diecezji krakowskiej.

${ }^{234}$ Łac.: nieznany, anonimowy.

a List pisany jest na podwójnej, nieliniowanej i przezroczystej kartce formatu kieszonkowego. Brak miejsca wystawienia dokumentu i znaku wodnego.

${ }^{235}$ Tomaszewski Edward (1862-1927), święcenia kapłańskie w 1887 r. we Lwowie, w 1891 r. przeszedł na obrządek ormiańskokatolicki; był wikariuszem katedralnym we Lwowie, 1902-1904 katecheta w lwowskich 
to jest żeś przeoczył, że ona [jest] moją diecezjanką. Mam do tego powody poważne, o których w części Tobie wczoraj wspomniałem.

Najoddańsze Ci łączę wyrazy

Lwów, d[nia] 29/XI [1]912

Teodorowicz

Dokument 82

Kochany Księże Arcybiskupie! ${ }^{\mathrm{a}}$

21/XII [1]912

Dziękuję Ci za szczegół cenny i naturalnie w sobotę wyjadę. Sapieha przybędzie. Dostałeś jego list co do poglądu Wałęgi? Ja na wszelki wypadek piszę i może co dowiozę na sobotę.

Ściskam Cię serdecznie i całuję

Twój Józef

\section{Dokument 83}

\section{Carissime $^{\text {!a }}$}

Już pisałem do drukarni. Wiele kazać odbitek zrobić wszystkich? Zatelefonuj mi jutro. Jest to wprost impertynencja, z jaką Komitet świecki dyktuje klerowi, jakie ma być nabożeństwo! Do czego to dochodzi. „Nabożeństwa powinny być uroczyste nie [zaś] żałobne”, a w „Wieku Nowym” ${ }^{236}$ przed paru dniami jakaś baba pisała, że to klerykały chcą nabożeństwa żałobnego, a my chcemy nieżałobnego ${ }^{237}$. Trzeba się zastanowić, co tu zrobić - najserdeczniej pozdrawiam

szkołach powszechnych, 1905-1911 administrator parafii w Horodence, 1911-1927 emeryt i kapelan szpitala dla umysłowo chorych we Lwowie-Kulparkowie. T. Zaleski, Stownik, s. 103.

a Powyżej obcą ręką niebieską kredką napisano nazwisko: „Teodorowicz”. List pisany jest na podwójnej, nieliniowanej kartce formatu kieszonkowego. Brak miejsca wystawienia dokumentu.

a List pisany na 2 stronicach czystego papieru formatu kieszonkowego. Na stronie tytułowej w górnej części niebieską kredką obcą ręką napisano: „Teodorowicz” i liczbę: „14”. Brak miejsca wystawienia dokumentu.

${ }^{236}$ „Wiek Nowy” - dziennik ukazujący się we Lwowie w 1. 1901-1939 o nakładzie 6000-35000 egz.; organ Polskiego Stronnictwa Postępowego. Z pismem identyfikował się obóz postępowo-demokratyczny. Funkcję redaktora pełnili do 1918 r.: Stanisław Piątkowski, Józef Krzysztofowicz, Bronisław Laskownicki. Po 1918 r. redaktorem był Bronisław Laskownicki, redaktorem odpowiedzialnym - Józef Krzysztofowicz. Prasa polska, passim; J. Jarowiecki, B. Góra, Prasa lwowska w dwudziestoleciu, s. 85; J. Jarowiecki, Prasa lwowska, s. 439-440.

${ }^{237}$ Aluzje do przygotowań obchodów 50. rocznicy powstania styczniowego. Tematyka ta zdominowała konferencję 10 XI 1911 r. zorganizowaną przez abp. J. Teodorowicza we Lwowie z udziałem abp. J. Bilczewskiego, bp. J. S. Pelczara i bp. A. S. Sapiehy. Ustalono wówczas potrzebę opublikowania listu pasterskiego O miłości Ojczyzny oraz zorganizowania w poszczególnych diecezjach galicyjskich nabożeństw żałobnych. Ostatecznie 14 I 1913 r. abp Teodorowicz wspólnie z abp. Bilczewskim ustalili tekst odezwy jubileuszowej. 
Józef

$14 / \mathrm{I}[1] 913$

\section{Dokument 84}

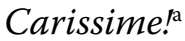

Piszę na razie naprędce. Był u mnie Bob[rzyński ${ }^{238}$ w całej tej sprawie ${ }^{239}$ na długiej rozmowie. Później opowiem. Wobec ciągłych ataków i poczynających iść pocisków w gazetach, postanowiliśmy jednak zrealizować uchwalę episkopatu co do ogłoszenia w dziennikach i to zaraz. Dołączam Ci jej tekst, z którego widzisz puentę. Otóż w interesie zgody obu narodowości jesteśmy przeciw ustawie, która wprowadza przez swój separatyzm polityczny także separatyzm religijny i narodowy. Teraz nam nikt nic zarzuci, że stajemy przeciw Rusinom. Przeciwnie: my właśnie za zgodą jesteśmy. Namiestnikowi na jego zapytanie powiedziałem, że episkopat w zasadzie był uchwalił poinformowanie opinii o swym stanowisku, a przed puszczeniem notatki do gazet puściłem list, w którym go zawiadamiam, że wraz z Sapiehą ułożyliśmy notatkę i uzasadniłem nasze stanowisko. Nawiasem dodam, że z Pinińskim porozumiałem się przedtem i on uważał za bardzo wskazane ukazanie się co rychlejsze takiej naszej notatki. Odczytałem mu jej tenor.

Pewno wypoczywasz teraz w Rzymie ${ }^{240}$. Lecz i u nas ślicznie. Najserdeczniej pozdrawiam Cię oddany Ci zawsze

Miała ona wyjść w formie broszury, ale bez podpisów autorów, bowiem bp L. Wałęga nie zgodził się na wspólne orędzie całego episkopatu. Kontrowersje wśród hierarchów wywołała na pozór błaha sprawa kolorów szat liturgicznych, w których celebrowano wspomniane rocznicowe nabożeństwo. Początkowo ustalono kolor czarny - znak żałoby, ale lokalne komitety organizacyjne domagały się koloru białego - symbolu uroczystych nastrojów. We Lwowie zgodził się na tę zmianę - rzekomo pod wpływem enuncjacji „Gazety Narodowej” - abp Bilczewski, co wyrzucał mu tarnowski bp Wałęga. Ten ostatni upierając się przy pierwotnych ustaleniach, a nie znając nowych decyzji metropolity, naraził się na zarzuty braku patriotyzmu i złośliwej niechęci względem narodowo nastawionych określonych sfer polskiego społeczeństwa. AALK, bsygn., J. Bilczewski, Dziennik, s. 228-229, 242; J. Wołczański, Listy biskupa, s. 303-307.

a List pisany na 3 stronicach czystego papieru formatu zeszytowego. W lewym górnym rogu obcą ręką niebieską kredką napisano: „Teodorowicz”.

${ }^{238}$ Bobrzyński Michał (1849-1935), dr praw, habilitacja w 1873 r. na UJ, 1877 r. prof. nadzwyczajny historii prawa niemieckiego, 1879 r. prof. zwyczajny UJ, od 1902 r. prof. prawa politycznego, od 1885 r. poseł do Sejmu Galicyjskiego i Rady Państwa, zwolennik programu konserwatystów krakowskich „stańczyków”, 1891-1901 wiceprezydent Rady Szkolnej Krajowej, 1908-1913 namiestnik Galicji; na tym stanowisku zajął się problemem reformy ordynacji wyborczej do Sejmu Galicyjskiego, której nie zdołał uchwalić oraz zagadnieniem szkolnictwa ukraińskiego. Opowiadał się za przyznaniem Ukraińcom praw do rozwoju kulturowego w granicach Polski. Po dymisji przebywał w l. 1913-1914 we Włoszech, w 1917 r. mianowany ministrem dla Galicji, ale wnet zrezygnował z urzędu. W 1914 r. przeniósł się do Wielkopolski, gdzie zmarł. S. Estreicher, Bobrzyński Michat, w: PSB, t. 2, red. zbior., Kraków 1936, s. 165-168.

${ }^{239}$ Chodzi o kwestię przygotowywanej reformy ordynacji wyborczej.

${ }^{240}$ Zgodnie z decyzją powziętą „od miesięcy”, abp J. Bilczewski wyjechał 30 III 1913 r. do Rzymu via Wiedeń. Formuła ta była taktycznym wybiegiem metropolity w obliczu planowanego na początku kwietnia 1913 r. głosowania w Sejmie Galicyjskim nad reformą ordynacji wyborczej. Dnia 12 marca t.r. namiestnik 
Najserdeczniej pozdrów księdza Wałęgę.

Lwów, d[nia] 2/III [1]913

Teodorowicz

\section{Dokument 85}

\section{Carissime $!^{\text {a }}$}

W tej chwili telefonuje Sapieha, że we wtorek wieczór przyjeżdża. Sproś tedy biskupów na konferencję we środę ${ }^{241}$. Wesołego Alleluja!

Teodorowicz

Lwów, d[nia] 22/III [1]913

\section{Dokument 86}

\section{Carissime $^{\mathrm{a}}$}

Sapieha gotów przybyć w środę, ale naturalnie dla wspólnej konferencji, więc przynaglij Pelczara. Lub też może wystarczy we trójkę rzecz omówić, jeśli tamci przybyć nie zechcą. Może mi przyślesz list Wałęgi? Ja niestety jestem z przemęczenia chory i zwlokłem się z łóżka, nawet ceremonii nie mogę odprawiać. Wiczkowski był u mnie wczoraj i kazał mi natychmiast wyjechać, bo boi się powrotu choroby sprzed 2 lat.

\section{Całuję Cię najserdeczniej}

Józef

23/III [1]913

Michał Bobrzyński prosił abp. Bilczewskiego o obecność wszystkich hierarchów kościelnych w sali sejmowej, bowiem liczyć się miał każdy głos. Biskupi jednak, uznając projekt ordynacji za szkodliwy dla Kościoła i polskiej społeczności w Galicji, odrzucili petycję namiestnika. Lwowski metropolita przybył do Wiecznego Miasta 1 kwietnia wraz z bp. Wałęgą, udając się w podróż powrotną dopiero 18 kwietnia; do Lwowa wjechał 23 kwietnia. AALK, bsygn., J. Bilczewski, Dziennik, s. 251-282.

a Powyżej obcą ręką niebieską kredką napisano nazwisko: „Teodorowicz”. Informacja zapisana jest na pojedynczej, nieliniowanej kartce formatu zeszytowego. Znak wodny przedstawia dzwonki.

${ }^{241}$ Konferencja odbyła się 26 III 1913 r. w pałacu łacińskich arcybiskupów lwowskich. Brali w niej udział: abp Bilczewski (Lwów), bp Pelczar (Przemyśl), bp Sapieha (Kraków), bp Wałęga (Tarnów) i abp Teodorowicz (Lwów). Gospodarz spotkania relacjonował przebieg spotkania na kartach swego dziennika: „Omówiliśmy blokowy projekt reformy wyborczej. Uznaliśmy, że szkodliwy pod wzgl[ędem] religijnym i narodowym. Wprowadza powszechne głos[owanie], jakiego nie ma w innych krajach koronnych. Wprowadza zradykaliz[owanie] sejmu. Radykali polscy + ruscy + socjaliści + Żydzi gotowi mieć większość, Miasta wschodniej Galicji wpadną w ręce Żydów. Wprowadzenie dla Rusinów Kurii przy wyborze do Wydz[iału] Kraj[owego] itd. jest początkiem podziału kraju. Postanowiliśmy nie brać udziału w obradach sejmu, w głosow[aniu]. Jak tedy od miesięcy postanowiłem, jadę zaraz do Rzymu. Jedzie też Ks. Wałęga”. AALK, bsygn., J. Bilczewski, Dziennik, s. 254-255.

a List pisany na 1 stronicy czystego papieru formatu zeszytowego. W lewym górnym rogu niebieską kredką obcą ręką napisano: „Teodorowicz” i liczbę: „23”. Brak miejsca wystawienia dokumentu. 


\section{Dokument 87}

"Gazeta ${ }^{a}$ Narodowa" sfuszerowała napisem: enuncjacja. Naprawiłem to zaraz podając do pism innych, jako wiadomość z autentycznego źródła ${ }^{242}$. Był czas najwyższy by to zrobić. Naszą nieobecność już zaczęto komentować w prasie robiąc aluzję do nagłego wyjazdu. Wyglądało to na ucieczkę. A tak określamy jasno nasze stanowisko.

Żydowska „Gazeta Wieczorna"243 strzeliła już w nas. Numer załączam. Delegaci nauczycieli na zebraniu oświadczyli, że wolą raczej czekać z płacami na odroczoną reformę, byle dobrą. Wprawdzie to zrobione było prywatnie, ale daje świadectwo o tym.

Ściskam najserdeczniej

Lwów, d[nia] 3 kwietnia

Józef

\section{Dokument 88}

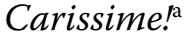

Notatka nasza narobiła niebywałej wrzawy, ale dzięki Bogu wszystko jest na najlepszej drodze. Teraz przychodzą na nas próby zastraszania nas. Namiestnik twierdzi, że wydostanie od biskupów list, z którego się wykaże, że notatka w gazetach nie była na konferencji biskupów uchwalona, a znowu Szeptycki wije się jak w ukropie mucha, bo się boi Rzymu. Już wysłał list do Ciebie, albo też wyszle ${ }^{\mathrm{b}}$ dzisiaj. Mówił mi o treści tego listu ${ }^{244}$. Na wszelki wypadek podaję Ci pomysł do odpowiedzi jemu, gdyż wiem na

a Powyżej obcą ręką niebieską kredką napisano nazwisko: „Teodorowicz”. Brak tytulatury i daty rocznej. List pisany jest na pojedynczej, nieliniowanej kartce formatu zbliżonego do A4. W dolnej części kartki widoczne są dwa identyczne i fragmentaryczne kołowe znaki wodne z czytelnym napisem: „Universal”. Na odwrotnej stronie kartki ołówkiem napisana jest cyfra „3”.

${ }^{242}$ Nawiązanie do komunikatu episkopatu galicyjskiego, wyjaśniającego opinii publicznej absencję biskupów w debacie sejmowej nad reformą ordynacji wyborczej.

243 "Gazeta Wieczorna” - dziennik wychodzący we Lwowie w l. 1910-1935, założony i redagowany przez Rogera Battaglię, redaktorem odpowiedzialnym był Jerzy Konarski, od 1919 r. red. odpow. Marian Machalski, od 1922 r. red. Stanisław Zachariasiewicz, od 1923 r. red. odpow. Mieczysław Trajdos, od 1924 r. red. odpow. Marian Machalski, red. Antoni Sadzewicz, od 1926 r. red. Jerzy Konarski, od 1928 r. red. odpow. Stefan Krzyżanowski, od 1930 r. red. nacz. Józef Reindler, red. odpow. S. Menczel, od 1933 r. red. odpow. S. Krzyżanowski. Nakład wynosił w 1917 r. 12000 egz., w 1921 r. - 25000 egz., w 1929 r. - 15000-20000 egz. Sądzono, że inicjatorem powstania pisma był namiestnik Bobrzyński, aby tym sposobem przeciwdziałać rosnącym wpływom Narodowej Demokracji; dotowane było przez sfery finansowo-rządowe. Prasa polska, passim; J. Jarowiecki, B. Góra, Prasa lwowska w dwudziestoleciu, s. 53.

a Powyżej dopisek ręką abp. Bilczewskiego: „otrzymałem rano 8/4”. List pisany jest jednostronnie na pięciu numerowanych i nieliniowanych kartkach formatu zbliżonego do A4. Wszystkie kartki posiadają ten sam okrągły znak wodny przedstawiający wewnątrz okręgu w otoku podwójny napis: „Universal” i liczbę „606”.

b Zgodne z oryginałem; poprawnie powinno być: wyśle.

${ }^{244}$ Reakcją episkopatu greckokatolickiego Galicji na planowaną reformę wyborczą był list abp. Szeptyckiego do abp. Bilczewskiego z 8 IV 1913 r. Autor wyraził ubolewanie z faktu, że uchwały episkopatu łacińskiego z 26 marca t.r. o uchyleniu się od głosowania nad reformą ordynacji wyborczej nie poprzedziła 
podstawie dłuższej dyskusji, o co jemu chodzi i czego należy się strzec w odpowiadaniu jemu. On chce mieć list od Ciebie taki, który by mógł pokazać nuncjuszowi na dowód, że nam nie chodzi o stanowisko katolickie, ale narodowe (!). Chce nadto zamanifestować wobec Rzymu chęci pojednawcze przez to, że nam proponował wspólną konferencję, a myśmy odmówili.

W końcu Tarnowski ${ }^{245}$ skierował ku nam drogą gazet publiczne zapytanie, a Badeni powołuje się na naszą oczekiwaną odpowiedź. Odpowiedź dziś episkopat musi dać, ale sądzę taką, by nie bardzo wchodzić w szczegóły i lekko dać do zrozumienia, że to znowu nie jest droga publicznie interpelować biskupów. Odpowiedź ta musi być jeszcze przed sejmem i nastąpić bezzwłocznie. Albo więc zechcesz Sam ułożyć taką odpowiedź, a my podpiszemy, albo też zgodzicie się na osnowę odpowiedzi, którą tu załączam. Brakuje jeszcze tylko zakończenia, które jutro dopiero dorobię. Jeślibyś się na tę osnowę zgodził, to dasz mnie i Sapieże plenipotencję, byśmy jeszcze myśli w niej zawarte o tyle oszlifowali, o ile byśmy to uznali za potrzebne, a następnie pozwolisz podpisać wszystkich biskupów. Byłoby może najlepiej w takim razie, gdybyś po prostu zatelegrafował: zgadzam się. To zgadzam się będzie upoważnieniem:

a) do opublikowania albo dosłownie tego tekstu z zakończeniem dorobionym, albo do dodania jeszcze jakich małych zmian przedsięwziętych wspólnie z Sapiehą,

b) do podpisania pod tą odezwą wszystkich biskupów ${ }^{246}$.

wspólna konferencja z episkopatem unickim Galicji. Abp Szeptycki pisał: „Sprawa reformy wyborczej jest sprawą ogólnokrajową, mającą dla obu narodowości kraj nasz zamieszkujących pierwszorzędne, dla obu narodów równe znaczenie. Jeśli przeto projekt reformy sprzeciwia się zasadzie katolickiej, jeśli są zasady prawa Bożego albo kościelnego, które nie pozwalają biskupowi katolickiemu a przeto i katolikowi - brać udziału w naradach nad projektem, a tym więcej za nim głosować, wszyscy powinniśmy solidarnie postąpić, by nie dać katolikom zgorszenia. My, ruscy biskupi, takiej zasady nie widzimy, że nam nie wolno usuwać się od głosowania a tym samym rozbijać ugody między dwoma narodami; sądzimy, że wzgląd na katolicką zasadę nakazuje nam raczej współdziałać z usiłowaniami doprowadzenia do zgodnego pożycia obu narodów. Dlatego zamierzamy gremialnie brać udział w naradach i głosować za projektem reformy wyborczej, ułożonym na podstawie porozumienia przedstawicieli obu narodów i wszystkich stronnictw w Sejmie. Stoimy przeto w zasadniczej sprzeczności z polskimi biskupami i ich uchwałą. Tą sprzeczność może usunąć tylko porozumienie, wspólna ogólna konferencja wszystkich katolickich biskupów w kraju”. Abp Bilczewski na gorąco po lekturze listu zanotował swoje wrażenia: „Otrzymałem list od X. Szeptyckiego w sprawie reformy. Dosiadł wielkiego konia. Już na święconym u mnie wyjaśniłem mu, że biskupi pol[scy] uchylimy się od głosowania, bo mamy uzasadnione obawy, że sejm przyszły będzie miał sporo Żydów, radykałów pol[skich] i rusk[ich]; że też nie mogę nabrać przekonania, żeby posłowie ruscy chcieli ugody szczerze, za którą miałaby pójść zgodna [w]spółpraca w kraju i Wiedniu". AALK, bsygn., J. Bilczewski, Dziennik, s. 270; AALK, bsygn., teczka: Korespondencja abp. J. Bilczewskiego z abp. A. Szeptyckim, List abp. Andrzeja Szeptyckiego do abp. Józefa Bilczewskiego, Lwów 8 IV 1913 r., rps.

${ }^{245}$ Tarnowski Stanisław (1837-1917), dr historii, od 1869 r. docent UJ, w 1871 r. prof. nadzwyczajny, w 1879 r. prof. zwyczajny tamże, w roku akad. 1882/83 dziekan Wydziału Filozoficznego, 1886/87 i 1899/1900 rektor Uj; od 1873 r. członek czynny Akademii Umiejętności, od 1883 r. sekretarz generalny, od 1890 r. prezes tejże. Był jednym z czołowych przywódców krakowskich konserwatystów; od 1867 r. poseł do Sejmu Galicyjskiego, od 1885 r. poseł do wiedeńskiej Izby Panów; od 1876 r. współwłaściciel „Czasu”, drukował artykuły publicystyczne na łamach „Przeglądu Polskiego”. T. Bujnicki, Stanisław Tarnowski (1837-1917), w: Uniwersytet Jagielloński. Wydziat Filozoficzny, red. J. Michalik, W. Walecki, Kraków 2000, s. 60-75.

${ }^{246}$ Abp Bilczewski zanotował od datą 8 IV 1913 r. w swoim dzienniku: „Przyszedł list Ks. Teodorowicza w sprawie reformy z tym, żeby się zgodzić na przedstawiony przez niego tekst enuncjacji episkopatu 
Wczorajsze sejmowe głosowanie było wielkim zwycięstwem przeciwników reformy. Wskazuje dzisiaj, że do 50 już jest tych, co wyjdą. Ponadto Piniński także zapowiedział publicznie, że w razie nie uwzględnienia poprawek wyjdzie i głosować nie będzie.

Jak bardzo było potrzebne opublikowanie notatki o naszym stanowisku, to Ci przytoczę następujący przykład. Szedłem z bratem ${ }^{247}$ ulicą, a kilku akademików poznawszy mnie zaczęło głośno wołać: „Skandal! Biskupi w taki czas się rozjeżdżają, a tu powinni być przy głosowaniu nad reformą". Schroniłem się w małą uliczkę bojąc się tumultacjii ${ }^{248}$. Po kawiarniach mówiono o naszej gremialnej ucieczce, jako niegodnej naszego stanowiska. Dziś się sytuacja notabene zmieniła. Sapieha wysłał list do nuncjusza z wyjaśnieniem i uzasadnieniem naszego stanowiska. „Reichpost” ${ }^{249}$ też pisze o tej reformie, jako dobrej dla żydówc.

Stapiński ${ }^{250}$ ma wnieść do nas korną i synowską (!) prośbę, byśmy lud popierali. Tak się dziś sytuacja przedstawia. Tyle na razie. Ściskam Cię najserdeczniej. Księdza Wałęgę proszę pozdrowić. Dobrze Wam tam ${ }^{251}$, a ja się stąd ani ruszyć mogę i jestem w ciągłych opałach. Namiestnik ${ }^{252}$ walczy prostym, ordynarnym kłamstwem. Ale prawda, że miałem zakończyć.

Lwów, [...] d [1]913

Twój Józef

w odpowiedzi hr. Tarnowskiemu. Naradziliśmy się z bisk[upem] Wałęgą; nie zgodziliśmy się na ten tekst; wysłałem w im[ieniu] nas obu telegram z tym, żeby w enunc[jacji] akcentować tylko moment religijny. Mamy obaj z b[iskupem] Wałęgą posmak, że w całej tej akcji u Ks. Teod[orowicza] zbyt wielką rolę odgrywa niechęć osobista. My stoimy obaj na stonow[isku], że jest wielkie prawdopodobieństwo, że ta reforma jaką dziś blok proponuje przyniesie szkodę Kościołowi. Nie współpracujemy nad jej poprawieniem, bo przedłożono ją jako gotową, jako rzecz przesądzoną". Jednakże abp Teodorowicz nie dawał za wygraną. Dnia 12 IV 1913 r. wysłał telegram do abp. Bilczewskiego z prośbą na wyrażenie zgody dołączenia podpisów obu biskupów bawiących wówczas w Rzymie pod odpowiedzią łacińskiego episkopatu Galicji dla Stanisława Tarnowskiego. Petycja ta wprawiła metropolitę w zakłopotanie, bowiem planowana nota nie tylko odbiegała od wcześniej ustalonego stanowiska biskupów przenosząc akcent na politykę stronnictw politycznych, ale w dodatku wykładała sprawy nie dość jasno. W odpowiedzi abp Bilczewski zgadzał się spełnić prośbę, ale tylko w razie rzeczywistej konieczności publikacji noty. Dnia 14 kwietnia nadszedł kolejny telegram abp. Teodorowicza informujący o publikacji enuncjacji, „że nie mogą biskupi zmienić stanow[iska]”. AALK, bsygn., J. Bilczewski, Dziennik, s. 271-273.

${ }^{247}$ Drugi brat abp. Teodorowicza - Michał (1868-1924), urzędnik Polskiej Krajowej Kasy Pożyczkowej, członek Zarządu Spółki Wydawniczej Drukarni „Polonia” we Lwowie. Zmarł 13 IV 1924 r. we Lwowie, pochowany na Cmentarzu Łyczakowskim tamże. Informacja pisemna mgr. Tomasza Krzyżowskiego, Kraków 14. XII $2017 \mathrm{r}$.

${ }^{248}$ Wyrażenie przestarzałe: bojkotu, poturbowania.

249 Tytuł niezidentyfikowany.

c Zgodne z oryginałem; poprawnie powinno być: Żydów.

${ }^{250}$ Stapiński Jan (1867-1946), pionier ruchu ludowego w Galicji, 1898-1900 i 1907-1918 poseł do austriackiej Rady Państwa, 1901-1908 poseł do Sejmu Galicyjskiego, od 1908 r. prezes Polskiego Stronnictwa Ludowego, w 1913 r. stanął na czele PSL-Lewicy, a w 1924 r. objął funkcję wiceprezesa Związku Chłopskiego, 1926-1928 wiceprezes Zarządu Głównego Stronnictwa Chłopskiego. W 1919 r. i w 1928 r. wszedł do Sejmu RP, 1902-1934 wydawca i redaktor „Przyjaciela Ludu”, 1928-1934 zwolennik sanacji, po $1934 \mathrm{r}$. wycofał się z życia politycznego. J. Hampel, Stapiński Jan, w: Kto byt kim, s. 436.

${ }^{251}$ Abp Bilczewski wraz z bp. Wałęgą nadal bawili w Rzymie.

${ }^{252}$ Wzmianka dotyczy Michała Bobrzyńskiego.

d Data nieczytelna. 
Wczoraj Bobrzyński stwierdził, że klub ruski jest radykalny ${ }^{253}$, wyraził tylko nadzieję, że się poprawią (?!).

\section{Dokument 89}

\section{Carissime! ${ }^{\mathrm{a}}$}

Wygraliśmy! Tak pisze o reformie ludowiec! W takiej kompanii będąc jesteśmy zupełnie chyba kryci.

Całuję Cię

Twój Józef

\section{Dokument 90}

\section{Carissime $^{\text {Ia }^{2}}$}

Wysłałem list do Ciebie do Rzymu, ale Cię z pewnością już nie zastał, więc piszę do Wiednia byś znał sytuację.

Nasza odpowiedź Tarnowskiemu wywołała wprost entuzjazm w całym kraju. Nawet dzienniki nam wrogie jak "Gazeta Wieczorna” chwaliły ją niesłychanie, a „Wiek Nowy” i inne milczały. Nawet „Kurier” 254 i „Naprzód” tendencyjnie opuszczały miejsca gdzie była mowa o ludzie. Słowem wygraliśmy nią. Jak $\mathrm{Ci}$ jednak telegrafowałem, oparcie się o radykalizm było ostrą formą, bo katolików pośrednio wiązało. Jeśli my głosimy quasi religijną wojnę, to ich rzeczą jest słuchać. Ale i to dobre. Dobre wobec Wiednia: Szeptycki w intervievie ${ }^{255}$ „Neue Freie Presse” ${ }^{\text {"256 }}$ rzucił na nas oskarżenie, że tylko polityczne względy nami kierują. Dziś mają o naszym liście odpowiedź, że nie. „Reichspost” we

${ }^{253}$ Ugrupowanie posłów ukraińskich w Sejmie Galicyjskim.

a Na lewo od tego adnotacja abp. Bilczewskiego: „ze Lwowa otrzymałem 7/4”. Powyżej obcą ręką niebieską kredką napisano nazwisko: „Teodorowicz”, a obok tego ołówkiem datę: „1913”. Informacja zapisana jest na kartce z notatnika, nieliniowanej, formatu zbliżonego do A4. Brak miejsca wystawienia dokumentu i datacji. Kartka posiada fragmentaryczny znak wodny przedstawiający napis: „Universal” wpisany w okrąg. Na odwrocie kartki ołówkiem napisana jest cyfra „7”.

a Powyżej obcą ręką niebieską kredką napisano nazwisko: „Teodorowicz". List pisany jest na dwóch pojedynczych, nieliniowanych kartkach formatu zbliżonego do A4. Brak miejsca wystawienia dokumentu i datacji. Papier posiada fragmentaryczne, okrągłe znaki wodne z czytelnym na tych fragmentach napisem: „Paper”.

254 „Kurier Lwowski” - dziennik polityczno-społeczny wychodzący we Lwowie w l. 1883-1935, adresowany do zwolenników ruchu ludowego. Redaktorami naczelnymi byli: Ludwik Masłowski, od 1884 r. Henryk Rywakowicz, od 1907 r. - Bolesław Wysłouch, w 1918 r. - H. Rywakowicz, od 1922 r. - Jan Dębski, od 1823 r. - Włodzimierz Jampolski, od 1927 r. - J. Geschwind. Nakład pisma wynosił 1200-10000 egz. Prasa polska, passim; J. Jarowiecki, B. Góra, Prasa lwowska w dwudziestoleciu, s. 60.

$255 \mathrm{Z}$ franc.: wywiadzie.

256 „Neue Freie Presse” - austriacki dziennik liberalny, powstał we Wiedniu w 1864 r., założony przez secesjonistów z redakcji „Die Presse”, w l. 1908-1920 redagował go M. Benedikt, 1934-1939 wychodził jako „Neuen Wiener Journal” i „Neuen Wiener Tagblat”. 
wstępnym artykule szeroko ujęła nasze stanowisko. Więc Wiedeń cały wie jasno, że tylko najbardziej zasadnicze względy nami kierowały w naszej decyzji.

Rzym oświadczył, że się nie chce mieszać w ogóle w tę sprawę. W kraju zaś jest rozdział na 2 obozy: radykalny i nieradykalny.

Nie mamy się co łudzić. Dzisiejszy rząd idzie w przymierzu społem z masonerią, żydostwem, radykalizmem. Demonstracyjnie patronował wiecowi Daszyńskiego we Lwowie. Dobrze, że wcześniej maska odkryta. Walka to walka. Ale co dalej robić? Nad tym się naradzimy w Krakowie. Tam dziś jadę. We Wiedniu podobno mają chrap[kę] na Ciebie, by Cię do Cesarza powołać. Tak przynajmniej pisała "Presse" ${ }^{257}$. Więc najlepiej może incognito nie przyjmując nikogo przysunąć się pod Wiedeń. Jeśli zaś będzie potrzeba przyjąć, to może przed omówieniem wspólnym sprawy będzie pożądanym nieangażowanie się w nic. Oni koło nas tańczą, bo mamy w naszym ręku cały klucz do sytuacji. Tyle na razie.

Do widzenia jutro w Krakowie. Proszę najserdeczniej pozdrów Księdza Biskupa Wałęgę.

Józef

\section{Dokument 91}

\section{Carissime $!^{\mathrm{a}}$}

Niedługo Ci daję spokoju. Nowa awantura. Pelczar nie porozumiawszy się z nami, na własną rękę napisał do Zaleskiego ${ }^{258}$, a Zaleski zaraz użył tego listu, by wykazać, że nie ma solidarności w episkopacie i że ten jest rozbity. Przysłał mi ustęp listu Pelczara, a równocześnie w „Neue Freie” 259 pomieścił ustęp, że tylko 4 biskupów jest reformie przeciwnych. Jutro zaś zjeżdża do Lwowa i nie wątpię, że na całej prawicy wystąpi przeciw nam. Sądzę więc, że chwili zwłoki nie ma i że należy byś wysłał do Pelczara telegram $\mathrm{z}$ wypowiedzią, w którym mu donosisz, że pertraktacje już przez nas spróbowane, ale bezskuteczne, że jego list do Zaleskiego wyzyskują do rozbicia naszej solidarności i że wobec tego żądasz od niego telegraficznego oświadczenia, iż się we wszystkim z nami solidaryzuje. Taki telegram niech wyśle do Lwowa, a ja się postaram o to, by telegram ten wzięto na wypadek, jeśliby Zaleski przeciw nam wystąpił.

$\mathrm{Z}$ drugą jeszcze sprawą był u mnie od Zaleskiego Abrahamowicz (Ciebie już we Lwowie nie było). Oto Zaleski żąda odpowiedzi obiecanej przez episkopat i zapytuje czy

257 Właściwie: „Neue Freie Presse”.

a List pisany na 2 stronicach czystego papieru formatu zeszytowego. W prawym górnym rogu nota napisana ręką abp. Bilczewskiego: „26/4 [1]913”.

${ }^{258}$ Zaleski Wacław (1868-1913), prawnik, ekonomista, członek Rady Państwa w Wiedniu, minister rolnictwa, 1912-1913 minister skarbu Austro-Węgier. H. Morawska-Stec, Wactaw Zaleski (1868-1913). Wspomnienia rodzinne, Poznań 2010, passim.

259 Właściwie: „Neue Freie Presse” - austriacki dziennik liberalny, powstał we Wiedniu w 1864 r., założony przez secesjonistów z redakcji „Die Presse”, w l. 1908-1920 redagował go M. Benedikt, 1934-1939 wychodził jako „Neuen Wiener Journal” i „Neuen Wiener Tagblat”. 
konferencja się odbyła? W „Czasie” zaś oświadczają konserwatyści, że od naszego stanowiska czynią zależne swoje. Wobec tego nie możemy zwlekać konferencji wspólnej do początku maja, ale musimy ją odbyć natychmiast. Inaczej oburzano by się na nas i za zwłokę zwalano by wszystko na nas. Telefonowałem do Sapiehy i on gotów nas przyjąć na konferencję już na wtorek. Najdalej we środę musimy się zjechać w Krakowie i odbyć konferencji wspólną ${ }^{260}$. Na niej ułożymy odpowiedź Zaleskiemu. Odpisz mi proszę natychmiast, a ja z Sapiehą wtedy porozumiem się do „Czasu”261 definitywnie.

Ściskam Cię serdecznie

Lwów, d[nia] 26/IV [1]913

Twój Józef

\section{Dokument 92}

Carissime! ${ }^{\mathrm{a}}$

Dziś się pojawi ta enuncjacja w „Gazecie Narodowej”, więc równocześnie niech ją drukuje "Głos Narodu”. Dajżeż niezwłocznie do redakcji. Przeczytaj korespondencję z Krakowa w dzisiejszym „Słowie”.

Ściskam Cię

J[ózef]

\section{Dokument 93}

\section{Carissime $!^{\mathrm{a}}$}

Proszę Cię na wszystko, chciej załatwić sprawę z broszurą, bo absolutnie dłużej czekać niepodobna. To nie przeszkadza w niczym śrubowaniu późniejszym Sapiehy. Ale też gdzie ludzie są obcy zwlekanie dalsze jest istotnie niemożliwe. Odsyłam Ci „Czas”. Ładnie, ani słowa, popisał się Zaleski, którego mowa jest zbywaniem naszego listu i oświadczenia.

${ }^{260}$ Konferencja biskupów galicyjskich obrządku łacińskiego z udziałem arcybiskupa ormiańskokatolickiego J. Teodorowicza odbyła się w piątek 2 V 1913 r. w Krakowie. Wśród uchwał znalazła się decyzja w sprawie wydania listu pasterskiego na temat wyborów do sejmu. Opracowanie listu zlecono abp. Teodorowiczowi. Zaaprobowano także tekst notatki pióra tegoż hierarchy, przeznaczonej dla Wacława Zaleskiego. AALK, bsygn., J. Bilczewski, Dziennik, s. 284-285.

${ }^{261}$ Prawdopodobnie na łamach krakowskiego „Czasu” miała ukazać się enuncjacja biskupów, streszczająca wyniki odbytej konferencji.

b W prawym dolnym rogu karty obcą ręką ołówkiem widnieje nota: „Teodorowicz”.

a AKMK, sygn. TS IV/98, Tekst pisany czarnym atramentem na jednej stronicy papieru formatu zeszytowego. Brak miejsca i datacji. W prawym górnym rogu nota ołówkiem ręka archiwisty: „TS IV/98”.

a Powyżej obcą ręką napisano nazwisko: „Teodorowicz” oraz dopisek ręką abp. J. Bilczewskiego: „chce żebym za Ks. Sapiehę zapłacił należność za druk broszury, listu past[erskiego]”. 
Życzę Ci raz jeszcze najlepszego powodzenia kuracji ${ }^{262} \mathrm{i}$ uścisk serdeczny przesyłam

Lwów, d[nia] 16/VIII [1]913

Twój Józef

\section{Dokument 94}

\section{Carissime $!^{\mathrm{a}}$}

Czy byś nie mógł odłożyć konferencji? I tak sejmu przed 20 nie otworzą, a dopiero po 15 poczną się zjeżdżać nasi politycy. Przed Korytowskim możesz złożyć na mnie, że zachorowałem. Istotnie tak jest. Tu winogrona powielają $[\ldots]^{\mathrm{b}} \mathrm{i}$ ja się tym formalnie strułem. Dziś mi już lepiej, ale skutkiem tego chciałbym pobyt przedłuźyć o kilka dni po pierwszym, by całkiem przyjść do siebie. Więc czy by można wezwać na 10-go, albo jeszcze lepiej 15-go. W ogóle mi jakoś zeszło z feriami: choć sam sobie w części winien jestem, bom za wiele pracował nad „Życiem Chrystusa” ${ }^{263}$ i mózg na nic wymęczyłem. Szwajcaria śliczna. [... $]^{c}$ mimo deszczu względnie pogodny, a w Abbacji dopiero dziś uśmiechnęło się słońce. Bawi w Lozannie Kakowski ${ }^{264}$, Bobrzyńskiego już nie ma, pojechał do Rzymu z zamiarem starania się o audiencję u papieża. Widziałem się tu ze Starzyńskim i omawiałem z nim projekty reformy. Dobrześ zrobił, żeś lojalnie się znalazł na cesarskie święto, bo gdyby nikogo nie było, powiedzianoby, że strajkujemy. Cieszę się, że jak mi mówią, pobyt choć krótki dobrze Ci zrobił, mimo forsowania w Gastein ${ }^{265}$ kąpielami ponad ordynację lekarską. (A co, jak wszystko wiem).

Ściskam Cię najserdeczniej, Twój oddany Ci

Józef

$$
\text { Abbacja, 27/VIII [1]913 }
$$

${ }^{262}$ Abp Bilczewski przebywał w dniach 14 VII - 14 VIII 1913 r. na wypoczynku w Karlsbadzie.

a List pisany na 3 stronicach czystego papieru formatu zeszytowego.

b Tekst nieczytelny.

${ }^{263}$ Abp Teodorowicz planował opracowanie 12-tomowej monografii poświęconej Chrystusowi. Pochłonięty wszakże udziałem w życiu kościelno-religijnym i społeczno-politycznym Polski, a ponadto ulegając sugestiom polskich biblistów przestrzegających go przed podejmowaniem tematyki bez fachowego przygotowania merytorycznego zdołał wydać zaledwie trzy tomy: Od Betlejem do Nazaretu (1932), Od Jahwe do Mesjasza (1936) i Herold Chrystusowy na tle epoki (1937).

c Tekst nieczytelny.

${ }^{264}$ Kakowski Aleksander (1862-1938), święcenia kapłańskie w 1886 r. w Warszawie, dr prawa kanonicznego, od 1887 r. pracował w warszawskim Konsystorzu Biskupim, 1887-1898 wykładał prawo kanoniczne i homiletykę dla alumnów Seminarium Duchownego w Warszawie, 1899-1910 był rektorem tej instytucji, wykładając zarazem teologię pastoralną, 1910-1913 pełnił urząd rektora Akademii Duchownej w Petersburgu, po czym 22 VI 1913 r. otrzymał nominację na arcybiskupstwo warszawskie, w 1919 r. mianowany został kardynałem, 1917-1918 wchodził w skład Rady Regencyjnej i Rady Stanu. L. Grzebień, Kakowski Aleksander, w: SPTK, t. 6, red. L. Grzebień, Warszawa 1983, s. 19-21.

${ }^{265}$ Gastein - miejscowość wypoczynkowa w Austrii. 


\section{Dokument 95}

Carissime $!^{a}$

Abbazia, willa Augusta, 30 VIII [1]913

Dziękuję Ci za urlop bardzo mi naprawdę potrzebny i pozostanę tu już do 10-tego. Nawet potrzeba tego dla sprawy. Chciałbym się rozmówić jeszcze ze Starzyńskim, który był tutaj, ale wyjechał potem, lecz znowu ma przyjechać. I im później się oświadczymy też lepiej, tym bardziej, że trzeba przeczekać ze względu na ten nieszczęsny spór, o którym mi piszesz. Dziękuję Ci za wycinek „Przeglądu”. Staś Tarnowski bardzo zmalał w oczach moich. Zaciekła partyjność zupełnie mu oczy zamgliła. Wolałby raczej, by sprawa przepadła, byle się pokazało, że Bobrzyński miał rację. Mam pociechę ze starego Małeckiego ${ }^{266}$, który jak czytam w gazetach spowiadał się; zapewne dzięki Tobie i stary gotów jeszcze żyćc6 ${ }^{267}$. Nęciłoby mnie bardzo kazanie na [...] $]^{\mathrm{b}}$ ale niestety mam referat mieć w Krakowie na jubileuszu Semenenki ${ }^{268}$ i Kajsiewicza ${ }^{269}$, a to bardzo trudna rzecz, wymagająca ogromnego nakładu czasu i pracy. Mój zaś mózg taki teraz niezdarny i wyczerpany, że muszę wypoczywać.

a List pisany na 2,5 stronicach nieliniowanego papieru formatu zeszytowego. W lewym górnym rogu karty tytułowej niebieską kredką obcą ręką napisano: „Teodorowicz”.

${ }^{266}$ Małecki Antoni (1821-1913), dr filozofii, 1850-1853 prof. filologii klasycznej UJ, w l. 1853-1856 pełnił tę samą funkcję na Uniwersytecie w Innsbrucku, 1856-1873 prof. nadzwyczajny języka i literatury polskiej w Uniwersytecie Lwowskim, od 1865 r. prof. zwyczajny tamże; w roku akad. 1871/72 dziekan Wydziału Filozoficznego, w 1872/73 rektor uczelni, w 1874 r. przeszedł na emeryturę. Był członkiem Rady Szkolnej Krajowej (1867-1870), od 1871 r. członek Rady Miejskiej Lwowa, 1876-1889 poseł do Sejmu Galicyjskiego, od 1881 r. dożywotni członek austriackiej Izby Panów. R. Skręt, Małecki Antoni Józef, w: PSB, t. 19, red. zbior., Wrocław 1974, s. 431-435.

267 Pod datą 25 VIII 1913 r. abp Bilczewski zanotował w podręcznym dzienniku: „Zachorował A[ntoni] Małecki. Trudności ze spowiedzią. Posłałem mu wiadomość, że chciałem go odwiedzić, ale nie mogę wobec tego, że oświadczył, że się nie będzie spowiadał”. Ale już następnego dnia metropolita dopisał: „Małecki się wyspowiadał. Odwiedziłem go. Siedzi, ale ma po operacji pęcherz[a] zapalenie płuc. Przytomny, sił jeszcze dużo. Ucieszył się, chciał ucał[ować] rękę. Zapewniałem, że się zań modlę, że odprawiłem mszę św. Uściskaliśmy się na pożegnan[ie]”. AALK, bsygn., J. Bilczewski, Dziennik, s. 307-308.

b Wyraz nieczytelny.

268 Semenenko Piotr (1814-1886), współzałożyciel Zgromadzenia Księży Zmartwychwstańców; w 1841 r. przyjął święcenia kapłańskie, ułożył regułę dla Zgromadzenia, 1842-1845 i 1873-1886 generalny przełożony, szereg lat pełnił funkcję mistrza nowicjatu, realizował ideę odrodzenia religijności Polaków w kraju i za granicą. W 1880 r. założył dom zakonny we Lwowie, w 1884 r. - w Krakowie, w 1863 r. zorganizował misję w Bułgarii, w 1866 r. otworzył w Rzymie Kolegium Polskie dla studiujących tam księży. W 1951 r. rozpoczął się jego proces beatyfikacyjny. H. E. Wyczawski, Semenenko Piotr Adolf Konstanty, w: SPTK, t. 4, red. H. E. Wyczawski, Warszawa 1983, s. 38-45.

${ }^{269}$ Kajsiewicz Hieronim (1812-1873), święcenia kapłańskie w 1841 r. w Rzymie; skodyfikował idee Bohdana Jańskiego odnośnie do erygowania zgromadzenia zakonnego poświęcającego się pracy nad odrodzeniem religijno-narodowym Polaków. Pracował w Paryżu (1842-1845, 1847, 1852) i w Rzymie, odwiedzał Wielkopolskę, Galicję, Niemcy i Anglię, 1845-1847 i 1855-1873 generał Zgromadzenia przeszczepiając jego struktury do USA, Kanady i Bułgarii; należy do współzałożycieli Zgromadzenia Sióstr Niepokalanek. B. Micewski, Kajsiewicz Ambroży Józef Hieronim, w: SPTK, t. 2, red. H. E. Wyczawski, Warszawa 1982, s. 229-240. 
W jakich to Ty opałach teraz! Wyobrażam sobie, jak Cię te tryby tej wielkiej maszyny porwały zupełnie. Tylko pilnuj snu i spacerów. To ostatnie jest w twej mocy i konieczne dla Ciebie. Kakowski zabawi tu jeszcze z 10 dni. Jest też Chotkowski ${ }^{270}$ i dużo księży. Szkoda, że żaden $\mathrm{z}$ Was nie był w Lublanie ${ }^{271}$. Bardzo brakowało tam bodaj jednego biskupa polskiego. Ja tak w pojedynkę nie bardzo miałem ochotę się wyrywać. Ale dość już mej trzęsącej się (piszę na okręciku) bazgraniny dla Twych oczu.

Najserdeczniej Cię pozdrawiam, zawsze Ci oddany

Józef

\section{Dokument 96}

\section{Carissime $^{\mathrm{a}}$}

Dziś jeszcze nic się nie stało, o czym by warto donosić. Konferencja wspólna klubów będzie dopiero w drugiej połowie tego tygodnia. Wszech Polacy się zgodzą mimo pewnych pozorów niezadowolenia dla ratowania honoru ${ }^{272}$. (Ale o tym sekret). Kraków bardzo niepewny. Sapieha pisze, że forma odezwy do Stapińskiego bardzo nieskuteczna i zrobi dużo kwasu ${ }^{273}$. Zresztą jest tego zdania, by każdy miał formę inną, a nie wszyscy jakby zmówieni jedną i tę samą.

Ściskam Cię serdecznie i życzę zdrowia dla przetrwania tarapatów

Lwów, 29/IX [1]913

${ }^{270}$ Chotkowski Władysław (1843-1926), święcenia kapłańskie w 1866 r., dr teologii, 1882-1910 prof. zwyczajny historii Kościoła na Wydziale Teologicznym UJ, 1885-1897 poseł do Rady Państwa, 1886-1898 członek Rady Miejskiej Krakowa, w roku akad. 1891/92 rektor UJ, od 1900 r. kanonik Kapituły Katedralnej, od 1908 r. członek Akademii Umiejętności w Krakowie. Specjalizował się w dziejach reformacji, zakonów i historii likwidacji unii. M. Jagosz, Chotkowski Władysław Longin, w: SPTK, t. 5, red. L. Grzebień, Warszawa 1983, s. 205-213; U. Perkowska, Ksiadz profesor Wtadysław Chotkowski (1843-1926). Historyk Kościoła, działacz społeczny i kaznodzieja, Lwów-Kraków 2016, passim.

${ }^{271}$ Prawdopodobnie odbył się tam zjazd poświęcony tematyce religijno-społecznej.

a List pisany na 2 stronicach czystego papieru formatu kieszonkowego.

272 Aluzje do tarć pomiędzy stronnictwami politycznymi w Galicji w przedmiocie reformy wyborczej.

${ }^{273}$ Podczas konferencji rzymskokatolickiego episkopatu galicyjskiego 22 IX 1913 r. we Lwowie, biskupi przyjęli projekt listu pasterskiego pióra bp. Leona Wałęgi, wymierzonego przeciwko Stronnictwu Ludowemu. Ponadto zredagowano tekst odezwy zakazującej wiernym popierania ludowców. Jednak zapewne wskutek dezaprobaty bp. Adama Stefana Sapiehy zwołano nową konferencję do Krakowa 8 X 1913 r., w czasie której wypracowano nowy tekst odezwy w myśl koncepcji bp. Pelczara. Zawierała ona wykaz kar za przynależność i sympatie ku Stronnictwu Ludowemu. Szerzej na ten temat zob.: J. Wołczański, Listy biskupa, s. 313-317. 


\section{Dokument 97}

Polecam ${ }^{a} \mathrm{Ci}$ profesora Neuratha ${ }^{274}$ jako zupełnie obiektywnego naukowego badacza. Racz go przyjąć i poinformować.

Ściskam najserdeczniej

Lwów, niedziela 21 XII [1]913

† Teodorowicz

\section{Dokument 98}

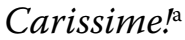

Nie weźmiesz mi za złe skoro Cię poproszę, byś mnie zwolnił odtąd od uczestnictwa we wspólnych konferencjach ${ }^{275}$.

Serdecznie Cię ściskam. Oddany Ci

Józef

Lwów, d[nia] 3/III [1]914

\section{Dokument 99}

\section{Carissime $^{\mathrm{a}}$}

Bardzo Ci dziękuję za list Twój i wiadomość o sobie. Boję się tylko, że melancholia $\mathrm{Iki}^{276}$ i niepogoda zaciążą Ci. Ale bodaj wypoczniesz trochę. Przykra Ci pewnie i dotkliwa wiadomość o śmierci biednego Wesolińskiego ${ }^{277}$; umarł też

a Tekst pisany na tekturowej karcie formatu biletu wizytowego. Na rewersie obcą ręką niebieską kredką napisano: „Teodorowicz”.

${ }^{274}$ Prawdopodobnie uczony austriacki. Złożył on wizytę tego samego dnia abp. Bilczewskiemu. Interesowała go kwestia religijnych relacji międzyobrządkowych w Galicji. Pytał gospodarza również o stosunki panujące $\mathrm{w}$ parafiach niemieckich; ponadto wybierał się $\mathrm{w}$ celach badawczych na Bukowinę. Wcześniej konferował na te tematy z abp. Szeptyckim. Abp Bilczewski zanotował w dzienniku: „Nie bardzo byłem kontent z jego wizyty, bo nie wiem, jak wyzyska informacje; trudno było odmówić wobec polecenia Ks. Teodorowicza". AALK, bsygn., J. Bilczewski, Dziennik, s. 342.

a Powyżej obcą ręką błędnie napisano nazwisko: „Puzyna”.

${ }^{275}$ W konferencjach episkopatu rzymskokatolickiego Galicji uczestniczył zwyczajowo pasterz Kościoła ormiańskokatolickiego abp Teodorowicz.

a List pisany na 4 stronicach czystego papieru formatu zeszytowego. W lewym górnym rogu karty tytułowej obcą ręką niebieską kredką napisano: „Teodorowicz”.

276 Abp Bilczewski przebywał w dniach 5-30 III 1913 r. w sanatorium dla duchowieństwa w kurorcie Ika.

277 Wesoliński Adam (1867-1914), święcenia kapłańskie w 1893 r. w Przemyślu, 1893-1895 wikariusz par. Święcany, 1896-1900 wikariusz par. Łączki, 1900-1901 wikariusz par. Kołaczyce, 1901-1902 wikariusz par. Rzeszów, 1902-1903 wikariusz par. Żołynia. Na zaproszenie abp. J. Bilczewskiego przeniósł się w $1903 \mathrm{r}$. do Lwowa, gdzie zajął się organizacją ruchu wydawniczego czasopism katolickich. Był redaktorem i wydawcą "Gazety Niedzielnej” (1903-1914) adresowanej do katolickich warstw ludowych Galicji Wschodniej. Drukował też dodatki: „Nauka Wiary”, „Niewiasta Polska”, „Anioł Stróż”. Zorganizował we Lwowie Biuro Pomocy Prawnej dla robotników chrześcijańskich; był członkiem zarządu Związku Katolicko-Społecznego. 
Bratkowski ${ }^{278}$. Strasznie śmierć u nas się zwija. Korytowski rozmawiał ze mną [o] sytuacji żaląc się, że Wałęga znowu Stapińskiego wysuwa pośrednio przez walkę z ludowcami. Broniłem stanowiska Wałęgi, jemu zaś samemu napisałem, aby koniecznie przyjechał do Lwowa i sam wyłuszczył sprawę Korytowskiemu. On też to zrobił, pisałem Ci też; nie wiem czy możliwe dziś będzie po tym, co się stało (opisałem mu sytuację dokładnie), byśmy czynili oświadczenia publiczne na rzecz jego. Sądzę jednak po osobistym widzeniu się z Wałęgą, że on jednak chciałby coś takiego od nas mieć. Będę się widział ze Sapiehą we Wiedniu, pomówię z nim o tym, a potem Ciebie zawiadomię. Chodzi przede wszystkim o to, w jakiej to formie należałoby uczynić. Z Korytowskim będę się jeszcze raz widział, wyjeżdżam do Jerozolimy jutro. A Ty niewierny Tomaszu jeszcze mnie podejrzewasz, że nie pojadę! Sapieha będzie we Wiedniu [w] poniedziałek rano. Bardzo Ci dziękuje za pamięć w modlitwie i będę gorąco Cię polecał na świętych miejscach. Potrzebujemy wszyscy Twojego zdrowia i sił, resztę już da Duch Święty. Leowi ${ }^{279}$ nie gratulowałem umyślnie. Tu u nas tej chwili jest śnieg.

Serdecznie Cię ściskam. Twemu sercu i pamięci się oddaję

Twój Józef

Lwów, d[nia] 13/III [1]914

\section{Dokument 100}

Piszę na dworcu na wyjezdnym. Dziękuję Ci za list, życzenia i modły. Napiszę więcej z Neapolu. Ojciec św. bardzo mi źle się wydał o sprawie berlińskiej, mówiłem mu - Walęga ma swój plan i nic go od tego nie odwiedzie. Chodzi dziś o to, czy Witos ${ }^{280}$ przez

Uczestniczył w pracy Chrześcijańskich Związków Zawodowych Małopolski Wschodniej, 1906-1908 poseł do Sejmu Galicyjskiego. J. Wołczański, Wesoliński Adam, w: SBKSwP, t. 3, red. zbior., Lublin 1995, s. $172-174$.

${ }^{278}$ Bratkowski Stefan (1853-1914), święcenia kapłańskie w 1882 r. w Zakonie oo. Jezuitów w Krakowie, pracował na placówkach jezuickich w Tarnopolu (1882-1884), Stanisławowie (1886-1888), Lwowie (18881892), Starej Wsi (1892-1893), Krakowie (1893-1914). Był założycielem we Lwowie pierwszej sodalicji mariańskiej dla studentów (1889 r.), w Krakowie - sodalicji uczniów szkól średnich (1895 r.) i kupców oraz mieszczan (1893 r.). Spieszył z pomocą materialną i moralną uczącej się młodzieży. Bratkowski Stefan, w: EWJ, s. 66.

${ }^{279}$ Leo Juliusz Franciszek (1861-1918), dr praw, w 1888 r. habilitował się z nauki skarbowości i prawa skarbowego w UJ, w 1891 r. prof. nadzwyczajny, 1893-1917 członek Rady Miejskiej Krakowa, 1904-1917 prezydent miasta i twórca Wielkiego Krakowa, 1901-1917 poseł do Sejmu Galicyjskiego; należał do stronnictwa konserwatywnego, potem przeszedł z Demokratycznego Koła Mieszczańskiego do obozu liberalno-burżuazyjnego; 1911-1917 poseł do parlamentu wiedeńskiego, w którym był prezesem Koła Polskiego (19121915). C. Bąk-Koczarska, J. Buszko, Leo Juliusz Franciszek, w: PSB, t. 17, red. zbior., Wrocław 1972, s. 66-70.

a List pisany jest ołówkiem na wizytówce z nadrukiem: „Mgr Joseph Teodorowicz. Archevêque Arménien Catholique de Leopol (Autriche)”. Brak autografu autora, miejsca wystawienia dokumentu i datacji. Ponadto ręką abp. Bilczewskiego dopisana ołówkiem jest data: „26/3 [ 1]914”.

${ }^{280}$ Witos Wincenty (1874-1945), rolnik, od 1903 r. wchodził w skład Rady Naczelnej Stronnictwa Ludowego, od 1908 r. poseł do Sejmu Galicyjskiego, od 1911 r. poseł do Rady Państwa w Wiedniu; w 1914 r. wybrano go wiceprezesem Rady Naczelnej PSL „Piast”, w 1918 r. został prezesem Polskiej Komisji Likwidacyjnej w Krakowie, 1917-1918 członek Ligi Narodowej, 1918-1931 prezes Zarządu Głównego PSL „Piast”, 
połączenie się ze Stapińskim u ludu straci, czy nie. Jeśli nie, to praca nasza zmarnowana. Wałęga jednak jest myśli najlepszej i twierdzi, że tak czy owak połączenie ze St[apińskim] nastąpiłoby prędzej czy później.

Ściskam Cię najserdeczniej.

\section{Dokument 101}

\section{Kochany Księże Arcybiskupie! ${ }^{a}$}

Mój list pisany wczoraj do Ciebie, jak się dowiaduję, jest już zupełnie bezprzedmiotowy. Tu bowiem do Wiednia dał znać Korytowski żeście w sobotę, a więc tuż przed mym przyjazdem, odbyli konferencję w Krakowie i że przyszła do skutku zgoda z konserwatystami ${ }^{281}$, dodajecie nowy liść wawrzynu do zasług namiestnika. Wobec tego oczywiście, że konferencja już odbyła się, racz mój [list] uważać za niebyły. Zresztą i co do Wałęgi nie jest sytuacja jego wcale tak krytyczna jak mi w pierwszej chwili we Wiedniu mówiono. Tym lepiej. Tu o zdrowiu Prochaski ${ }^{282}$ wszyscy się wyrażają z pewnym znakiem zapytania. Bo bądź co bądź długo się to wszystko przeciąga. Ja tu jeszcze do niedzieli zabawię, może sobie i odprawię rekolekcje.

Ściskam Cię serdecznie

Józef

w 1931 r. został prezesem Rady Naczelnej Stronnictwa Ludowego, 1920-1921 premier Rządu Obrony Narodowej, ponownie funkcję premiera pełnił w okresach: $28 \mathrm{~V}-14$ XII $1923 \mathrm{r}$. i $10 \mathrm{~V}-15 \mathrm{~V} 1926 \mathrm{r}$. W $\mathrm{l}$. 1929-1930 należał do przywódców Centrolewu; 10 IX 1930 r. aresztowany i więziony w Brześciu, 1933-1939 przebywał na emigracji w Czechosłowacji, 1936-1938 należał do opozycyjnego Frontu Morges. Więziony przez Niemców (1939-1941), ale nie podjął z nimi współpracy. Zmarł w Krakowie. J. Gołębiowski, Witos Wincenty, w: Kto byt kim, s. 74.

a List pisany na 1 stronicy kratkowanego papieru formatu zeszytowego. W lewym górnym rogu obcą ręką niebieską kredką napisano: „Teodorowicz”.

${ }^{281}$ Namiestnik Korytowski podczas wizyty u abp. Bilczewskiego 24 IV 1914 r. prosił, aby ten interweniował u bp. Wałęgi na rzecz zaprzestania walki ze Stronnictwem Ludowym „Piast”. Namiestnik opowiadał się za zjednoczeniem wszystkich stronnictw polskich do walki przeciwko Janowi Stapińskiemu. Metropolita obiecywał zwołanie w tej sprawie konferencji biskupów w Krakowie. Odbyła się ona w dniach 9-10 maja w rezydencji biskupa krakowskiego z udziałem gospodarza, abp. Bilczewskiego, bp. Pelczara i bp. Wałęgi. W pierwszym dniu dołączyli też: Stanisław Tarnowski, Zdzisław Tarnowski i baron Konopka. Biskupi opowiedzieli się za zgodną akcją wszystkich stronnictw narodowych, wymierzoną w Stapińskiego. W drugim dniu do biskupów dołączył namiestnik Korytowski. Uchwalono, że wpłynie on na „Piastowców”, aby wydali pojednawczą deklarację w stosunku do duchowieństwa. Wszyscy jednogłośnie zadeklarowali gotowość zwalczania Stapińskiego. Jednak abp Bilczewski zanotował: „W ogóle nie szły rozmowy w głąb - kwestie zasadnicze nie zostały należycie rozjaśnione - czasem zdawało się, że przyjdzie do większej burzy”. AALK, bsygn., J. Bilczewski, Dziennik, s. 386-387.

${ }^{282}$ Właściwie: Prohászka Ottokár (1858-1927), święcenia kapłańskie w 1892 r. w Esztergom (Węgry), od 1904 r. prof. teologii w Budapeszcie, 1905-1927 biskup diecezji Székesfehérvár (Węgry), przeciwnik zwalczanego przez Stolicę Apostolską na pocz. XX w. nurtu zw. modernizmem, propagator tzw. chrześcijańskiego socjalizmu, autor licznych publikacji teologicznych. W wyniku intryg duchowieństwa węgierskiego w 1911 r. oskarżono go o modernizm, a jego trzy książki znalazły się na Indeksie Ksiąg Zakazanych. J. Puciłowski, Biskup z indeksu kościelnego, „Znak”, 61(2009), nr 654, s. 75-83; T. von Bogyay, Prohászka Ottokár, w: LThK, Bd. 8, herausg. von J. Höfer, K. Rahner, Freiburg im Br. 1986, kol. 784-785. 
Wiedeń, V [1]914

Zgoda była potrzebna konserwatystom jako platforma wyborcza, z tym oni sami się nie tają. Przepraszam, że na takim piszę papierze, ale nie mam innego pod rękąa.

\section{Dokument 102}

\section{Carissime $^{\text {Ia }^{2}}$}

Wiedeń, 13/V [1]914

Powracam właśnie z podróży i dowiaduję się od Kulanowskiego ${ }^{283}$, że macie mieć konferencję w tych dniach nad sposobami obrony atakowanego Wałęgi ${ }^{284}$. To mu miał powiedzieć Ks. Pelczar. Otóż nie wiem, czy na tę konferencję przybędę, jeśli ona zaraz ma się odbyć, gdyż tu chciałbym sobie odbyć rekolekcje. W każdym razie chcę Ci napisać, co o tym sądzę i co za precedensa ${ }^{\mathrm{b}} \mathrm{w}$ tej sprawie się odbyły, o których miałem zamiar dopiero ustnie Ci relacjonować.

Wałęga w Twej nieobecności zwrócił się był do mnie z listem, w którym pisał o głosach prasy piastowej ${ }^{285}$ notującej nasze stanowisko w przeciwieństwie do Jego stanowiska, dodał, że spodziewa się ze strony naszej jakiegoś odwołania czy czegoś podobnego. (Szczegółów dokładnych listu już nie pamiętam). Musiałem wtedy jasno napisać Wałędze, że podobne odwołanie moim zdaniem niemożliwe, zwłaszcza, że passus ${ }^{286}$ mowy posła ludowego był oparty a raczej zawierał ustęp napisany przez Ciebie Długoszowi ${ }^{287}$. (Który następnie mnie pokazał, a ja znalazłem go dobrym). Otóż nie ma żadnej wątpliwości, że ten szczegół „Piast” w tej chwili wyzyska, jeślibyśmy my posyłali jakieś sprostowania wtedy ani Wałędze nie pomożemy, a episkopat skompromitujemy. Prosiłem Wałęgę o dyskrecję, by Cię przed czasem nie interpelował, a ponieważ chciałem Ci opowiedzieć wszystko i zostawić Ci możność zajęcia stanowiska. Tymczasem wobec ewentualności bliskiej tej konferencji i możliwości tej, że się tam nie znajdę, piszę Ci o tym wszystkim już teraz, gdyż sądzę, że i dzisiaj nie możemy się narażać na kompromitację publiczną. O mnie mniej tu chodzi, ale przede wszystkim chodzi o ciebie, a zresztą o pre-

b Brak daty dziennej.

a Powyżej obcą ręką niebieską kredką napisano nazwisko: „Teodorowicz”. List pisany jest na dwóch podwójnych, nieliniowanych kartkach formatu zeszytowego. Obie kartki posiadają ten sam znak wodny przedstawiający koronę, pod nią wstęgę i napis: „English Crownmill”.

${ }^{283}$ Postać niezidentyfikowana.

${ }^{284}$ Aluzja do trudnej sytuacji tarnowskiego bp. Leona Wałęgi, toczącego ostrą walkę z ludowcami na terenie diecezji.

b Zapis zgodny z oryginałem; poprawnie powinno być: precedensy.

${ }^{285}$ Mowa o organach prasowych Stronnictwa Ludowego „Piast”.

${ }^{286}$ Lac.: fragment.

287 Długosz Władysław (1864-1937), początkowo należał do Stronnictwa Narodowo-Demokratycznego, od 1908 r. do PSL; członek Rady Naczelnej, 1908-1914 poseł do Sejmu Galicyjskiego, 1911-1918 poseł do parlamentu wiedeńskiego, 1911-1913 minister dla Galicji. Po rozłamie PSL wszedł do Rady Naczelnej PSL „Piast”, 1922-1927 senator z ramienia tej partii. W 1928 r. wycofał się z życia politycznego. Dtugosz Wtadystaw, w: Kto byt kim, s. 505-506. 
stige ${ }^{288}$ episkopatu. Z drugiej strony w kołach politycznych tu się dowiaduję, że istotnie ataki na Wałęgę się ściągają, a namiestnikowi nie można w niczym dowierzać. Więc wedle mnie należałoby wziąć go w obronę i pomóc mu, tylko wszystko zależy od sposobu postawienia rzeczy. To, co powiedziałem o namiestniku opieram jeszcze na całkiem szczerym fakcie. Jak to on się odgrażał przede mną przynamniej, a myślę, że i przed Tobą na Jaworskiego. A dziś się dowiaduję, że najgoręcej Jaworskiego popiera w Sączu. Tacy to ludzie. Co do Wałęgi, to miałem z nim rozmowę w obecności jednej osoby, którą za powrotem Ci nazwę. Powiedziałem mu, że Wałęga zawsze dobre przewidywał rzeczy, że zresztą jest na miejscu i zna lepiej stosunki, że skargi ludowców są przesadzone, że jednak jeśliby $[\ldots]^{\mathrm{c}}$ we walce był za daleko idący nie wątpię, że go Wałęga zwolnić potrafi, gdyby jego księża poszli za daleko. On jednak wciąż powtarzał, że to inaczej było za Bobrzyńskiego, a inaczej za niego, że wreszcie on nie tknie nawet Stapińskiego, gdy mu Wałęga będzie psuł całą politykę, bo Stapiński pobije ludowców i na nim weźmie odwet za walkę wypowiedzianą jemu. To było przed dwoma miesiącami, dziś się musiało wiele odmienić. Jest jak jest, jedno stwierdzić się musi, że Wałęga poszedł w całej tej sprawie zupełnie na własną rękę, że wręcz nam pierwszą razą oświadczył, iż będzie działał nie oglądając się na nas. Po prostu na własną rękę i odpowiedzialność wziął wszystko. Nie myślę z tym ukrywać i przed nim, zresztą nie jest to tajemnica. Choćby więc on dziś miał zupełną rację o sposobie postępowania, a czy nie mieli racji, bądź co bądź poniekąd ponosi konsekwencje swego kroku i nie może nam stawiać zarzutów. Ale poza tym działa z najlepszą wolą i poprzeć go należy jak i pomóc mu tym bardziej, że po tym, co się dzieje jest nadzieja, iż w przyszłości będzie iść solidarnie.

Jak na mnie nabazgrałem wiele, więc czas kończyć. Z podróży jestem bardzo a bardzo zadowolony. Wezmę się już na dobre do pracy nad moim dziełem ${ }^{289}$. Modliłem się wiele za Ciebie.

Ściskam Cię i polecam się sercu i pamięci

Twój Józef

Z Sapiehą jeszcze się nie znosiłem, dziś do niego napiszę. Dopiero w drodze dowiedziałem się o śmierci Gołuchowskiej ${ }^{290}$.

\section{Dokument 103}

\section{Carissime! ${ }^{\mathrm{a}}$}

W tej chwili wracam od namiestnika, który mnie prosił na konferencję, dowiedziawszy się zaś w Konsystorzu od Bandurskiego, żeś w Jazłowcu, piszę do Ciebie. Sytuacja

${ }^{288}$ Fr.: prestiż, znaczenie.

c Tekst nieczytelny.

289 Abp Teodorowicz odbył wiosną 1914 r. podróż do Ziemi Świętej. Gromadził m.in. materiały do wielotomowej monografii Chrystusa, z której w l. 1932-1937 ukazały się trzy tytuły.

290 Postać niezidentyfikowana.

a List pisany na 1 stronicy czystego papieru formatu A4. W lewym górnym rogu obcą ręką niebieską kredką napisano: „Teodorowicz”. 
bardzo poważna i konieczna narada biskupów. Wałęga ofiarował się z gotowością przybycia do Lwowa namiestnikowi, ja w Twej nieobecności pozapraszam tamtych.

Jedyny termin możliwy ze względu na namiestnika i Wałęgę jest piątek. Dlatego wróć koniecznie z wizytacji we czwartek wieczór. Na wieczór w piątek namiestnik nas prosi na kolację. Czekam telegraficznej wiadomości, a tymczasem ściskam najserdeczniej

Twój Józef

Lwów, wtorek 23/VI [1]914

\section{Dokument 104}

\section{Carissime $^{\mathrm{a}}$}

Wiedeń, 8/VII [1]914

Jechałem do Krakowa z Korytowskim i marszałkiem ${ }^{291}$, którzy w Przemyślu wysiedli. Korytowski pokazał mi dokument, w którym mu donoszą, że piastowcy już się porozumieli ze Stapińskim i układ nawet jest znany w szczegółach. Przełożonym nowej grupy ma być Bernadzikowski ${ }^{292}$, do czasu wyborów mogąc iść dla pozorów osobno, potem razem. Trzeba na to naiwności Korytowskiego, by sądzić, że on chłopów jednak od Stapińskiego odciągnie. Napisałem mu z Krakowa obszerny list, w którym wykazałem, że to są iluzje. List odczytałem Sapieże i Wałędze.

Otóż my dziś ani na chwilę nie możemy dać się ciągnąć Korytowskiemu, który nawet wobec dokonanego faktu jeszcze myśli piastowca ratować od Stapińskiego. Dla nas piastowcy są identyczni ze Stapińczykami. Wałęga ani myśli rezygnować. Sądzę, że jeśli pojedzie do Rzymu to po to, by sprawę swoją uzasadnić i przedstawićc ${ }^{293}$. Ale i tego nie myśli czynić zaraz, dopiero we wrześniu.

Mieliśmy naradę we 3 i uznaliśmy za konieczne ogłoszenie w „Gazecie Kościelnej” komunikatu, który tu załączam. Myśleliśmy o podpisach osobistych, ale stanęło na tym, że taki akt, jak tu załączony, zupełnie wystarczy. Bądź tak dobry, jeśli Ci to odpowiada, zaraz ogłosić. Bo w każdym razie dłuższe zwlekanie z wyjaśnieniem sprawy zwłaszcza wobec paktu zacznie być już gorszącym. Dziś jadę do [...]. Lekarz bardzo chwalony. Sanatorium dobre. Stamtąd Ci napiszę.

Serdecznie Cię pozdrawiam

Józef

a List pisany na 1 stronicy czystego papieru formatu A4. W lewym górnym rogu obcą ręką niebieską kredką napisano: „Teodorowicz”.

${ }^{291}$ Funkcję ówczesnego marszałka Sejmu Galicyjskiego pełnił w latach 1913-1914 Adam Gołuchowski.

292 Postać niezidentyfikowana.

${ }^{293}$ W dobie trwających napięć pomiędzy bp. Wałęgą, ludowcami oraz namiestnikiem Galicji, pasterz tarnowskiej diecezji nie wykluczał możliwości rezygnacji z biskupstwa w sytuacji, gdyby z jego powodu dobro publiczne miało ponieść szkodę. Decyzja ta wszakże miała wyjść - jego zdaniem - ze strony Stolicy Apostolskiej, nie zaś wymuszona przez polityków. Dodać trzeba, że tego rodzaju sytuacja nigdy nie zaistniała. AALK, bsygn., J. Bilczewski, Dziennik, s. 386-387, 392-396.

b Tekst nieczytelny. 
Ależ ten Korytowski postąpił z Pelczarem! Także i Wałędze mówił: oddałbym order przemyskiemu biskupowi, ale czy mogę to zrobić skoro biskupi tak postępują? Może uwiadomisz Pelczara? Jeśli znajdę czas sam do niego dziś parę słów rzucę.

\section{Dokument 105}

\section{Carissime $!^{1 \mathrm{a}}$}

Ależ to nonsens niebywały taka argumentacja Pelczara. Tu przecie o co innego chodzi zupełnie, a na wypadek wojny listu tego w niczym poprawiać i zmieniać nie będzie potrzeba. Owszem tym lepiej, bo się na nim oprzemy, a myśli przed wojną wypowiedziane będą miały tym większą dowodową siłę. A nawiasem mówiąc - wojny nie będzie. Dziś mam tyle posiedzeń do rana, że w jednej chwili możliwej o godzinie 3-ciej będę się starał wpaść do Ciebie jeśli nic nie przeszkodzi

Ściskam Cię i całuję

Twój Józef

\section{Dokument 106}

\section{Carissime $^{\text {Ia }^{2}}$}

Czwartek, 30 VII [1]914

Właśnie z tym samym chciałem być dziś u Ciebie. Tylko rano jest mi to niemożliwe, bo sam wyjść z domu nie mogę, więc albo Ty do mnie przyjdź rano, albo też ja do Ciebie wstąpię koło [godz.] 5. Jeśli nie będziesz u mnie rano to znak, że mam przyjść do Ciebie. Ściskam Cię serdecznie

Józef

\section{Dokument 107}

\section{Carissime! ${ }^{\mathrm{a}}$}

Przepraszam Cię najmocniej za wczorajsze. Ale dowiedziałem się w znanej sprawie to tu taki i nie mogąc nic wymyszkować (Rutowski w rannych godzinach nie do złapania), poszedłem do Badeniego, który właśnie w tej kwestii miał mieć informacje i opowiadać je. Tymczasem służący mi mówi, że otrzymał list od Ciebie i właśnie do Ciebie poszedł.

a Powyżej obcą ręką niebieską kredką napisano nazwisko: „Teodorowicz”. List pisany jest na podwójnej, nieliniowanej kartce formatu zeszytowego. Brak miejsca wystawienia dokumentu i datacji. Kartka posiada znak wodny, herb oraz napis: „JOYSON'S Parchment”.

a List pisany na 1 stronicy czystego papieru formatu zeszytowego. Brak miejsca wystawienia dokumentu. W lewym górnym rogu obcą ręką niebieską kredką napisano: „Teodorowicz”.

a List pisany na 1 stronicy czystego papieru formatu zeszytowego. Brak miejsca wystawienia dokumentu. W lewym górnym rogu obcą ręką niebieską kredką napisano błędnie: „Weber”. 
Myślałem tedy, żeś na pewno już i z pewnego źródła poinformowany, więc i nie pisałem więcej. Dopiero później się dowiaduję żeś do mnie posyłał. Przepraszam raz jeszcze, ściskam najserdeczniej.

Twój Józef

\section{Dokument 108}

\section{Carissime $^{\text {Ia }^{2}}$}

Zdaje mi się, że byłoby bardzo wskazanym, byś zaprosił i marszałka ${ }^{294}$. Będzie to zrównoważenie. [... $]^{\mathrm{b}}$ przedstawi to, jako wyszczególnienie jego osoby. Odniosłem wrażenie, że na tym mu głównie zależy. Z marszałkiem zmienia się charakter cały przyjęcia. Rozważ i zrób jak uważasz.

Serdecznie Cię ściskam

Wtorek, 29/VI [1]915

Józef

\section{Dokument 109}

$\mathrm{A}^{a}$ no dobryś sobie! Właśnie Cię miałem o to samo pytać i list leży na stole do wysłania. Wobec afiszowanego rozkazu jesteśmy kryci na przyszłość, a demonstracja jest niemożliwą. Więc nie ma co, trzeba jak niepysznym wywiesić295. Dokąd to wszystko idzie? Do miłego obaczenia na dziś po obiedzie.

Twój.

\section{Dokument 110}

Jak słyszę, Twoja Kapituła chorągiew wywiesiła. Co wobec tego?

a List pisany na 1 stronicy czystego papieru formatu zeszytowego. W lewym górnym rogu obcą ręką niebieską kredką napisano błędnie: „Weber”.

${ }^{294}$ Funkcję ówczesnego a zarazem ostatniego marszałka Sejmu Galicyjskiego pełnił w latach 1914-1918 Stanisław Niezabitowski.

b Dwa wyrazy nieczytelne.

a Na wizytówce adnotacja ręką abp. Bilczewskiego: „6/8 [1]915 w sprawie wywieszenia chorągwi”. Tekst pisany jest obustronnie na wizytówce z nadrukiem: „Arcybiskup Teodorowicz”. Brak tytulatury, autografu autora i datacji.

295 Dnia 6 VIII 1915 r. na mocy zarządzenia władz austriackich, na ulicach Lwowa pojawiły się plakaty $\mathrm{z}$ rozkazem wywieszenia chorągwi na gmachach z powodu zdobycia przez wojska niemieckie Warszawy. AALK, bsygn., J. Bilczewski, Dziennik, s. 516.

a Tekst napisany na bilecie wizytowym z nadrukiem: „Arcybiskup Teodorowicz”. Brak tytulatury, miejsca wystawienia dokumentu, datacji i autografu autora. 


\section{Dokument 111}

\section{Carissime $^{\text {!a }}$}

Nie wiem, czy mi głowy nie zmyjesz za to, że się zarządziłem samowolnie. Ale tak byłem pod wrażeniem tumanerii pana C[olarda $]^{296}$, żem sobie pomyślał: za wiele to honoru pisać do tego jegomościa memoriały, a potem to będzie bardzo późno. Więc dałem do „Kuriera” streszczenie naszego przemówienia. Miałem być z tym u Ciebie, ale stał mi z redakcji nad głową, musiałem spieszyć i nie było już czasu do Ciebie iść. Więc rozgrzesz mnie łaskawie. Rzecz ta sama, mniej nas wiąże niż memoriał, w czas podana, bez wielkiego zaszczytu dla persony, którą tu zaczynają brać ze śmiesznej strony. Może jeszcze skoczę do Ciebie jeśli czas znalazł. Ollender ${ }^{297}$ Cię okłamał, ale przyślij jego oświadczenie na piśmie, by można również urzędowo stwierdzić jego kłamstwo.

Ściskam Cię

Sobota, d[nia] 28/VIII [1]915

Twój Józef

\section{Dokument 112}

\section{Carissime $^{\text {Ia }^{2}}$}

Wybierałem się właśnie dzisiaj do Ciebie, ale skoroś łaskaw, to bardzo proszęi oczekuję. Ściskam Cię serdecznie

niedziela, 28/XI [1]915

Twój Józef

\section{Dokument 113}

\section{Carissime $!^{\mathrm{a}}$}

a Powyżej na lewo obcą ręką niebieską kredką napisano błędnie nazwisko: „Puzyna” oraz ołówkiem dodano liczbę: „28”. List napisany jest na pojedynczej, nieliniowanej kartce formatu zbliżonego do A4. Brak miejsca wystawienia dokumentu i znaku wodnego.

${ }^{296}$ Mowa o nowym namiestniku Galicji gen. Hermanie von Colard (1857-1916), sprawującym tę funkcję w l. 1915-1916. Dnia 27 VIII 1915 r. obaj arcybiskupi lwowscy: Teodorowicz i Bilczewski złożyli mu wizytę, przedstawiając najpilniejsze potrzeby kraju. Metropolita łaciński zanotował zasadnicze dezyderaty: „Przedstawiliśmy konieczność najrychl[ejszego] ekon[omicznego] dźwignięcia kraju; 2) żeby nie wietrzono wszędzie zdrady, a w razie konieczności ludzi poważnych przesłuchiwano z wolnej stopy; 3) żeby życzliwe zajął stanowisko, gdy poczynimy kroki o założenie dziennika katolickiego". AALK, bsygn., J. Bilczewski, Dziennik, s. 523-524.

297 Postać niezidentyfikowana.

a List pisany jest na podwójnej, nieliniowanej o odcieniu niebieskim kartce formatu kieszonkowego. Brak miejsca wystawienia dokumentu. Znak wodny przedstawia napis: „Mill Paper”.

a List pisany na 1 stronicy czystego papieru formatu zeszytowego. Brak miejsca wystawienia dokumentu. W lewym górnym rogu obcą ręką niebieską kredką błędnie napisano: „Puzyna”. 
Sprawa istotnie fatalna. Nie możemy jednak my dwaj się cofać, jeśli zostanie Bielec$\mathrm{ki}^{298}$. Jedyne możliwe uzasadnienie byłoby w tym, że do finansowych operacji najmniej się nadają firmy duchowe. Oczywiście miałbyś sam to zrobić i to mając rękojmię, że odpowiednio potrafię uzasadnić gdzie należy.

Ściskam Cię serdecznie

Może by z Michalskim ${ }^{299}$ pomówić, a na razie wstrzymać ogłoszenie?

Twój J[ózef]

\section{Dokument 114}

\section{Carissime! $^{\text {a }}$}

Jutro pomówię z Tobą o tej sprawie rolnej. Otóż do mnie zgłaszał się o przyjęcie reformat. Sam miejsca w diecezji nie mam, więc go przyjąć nie mogę. Na wszelki sposób posyłam go do Ciebie, nie rekomendując, tylko przedkładając jej sprawę, na wypadek jeślibyś księdza potrzebował. Z decyzją się wstrzymaj, aż jutro się z Tobą zobaczę.

Serdecznie pozdrawiam i ściskam

Józef

Lwów, 1/VI [1]916

\section{Dokument 115}

\section{Carissime! ${ }^{\mathrm{a}}$}

Był u mnie wczoraj Janowicz ${ }^{300}$ z tym, że mieszczanie chcą być u Ciebie i u mnie $\mathrm{z}$ deputacją, by nas uprosić pójście $\mathrm{z}$ nimi do Dillera ${ }^{301}$, lub też o pośredniczenie u niego.

${ }^{298}$ Właściwie: Bielecki Andrzej/Biłeckyj Andrej (1847-?), święcenia kapłańskie w 1872 r. w obrządku greckokatolickim we Lwowie, prałat papieski, kanonik Kapituły Metropolitalnej, referent Kurii Metropolitalnej, oficjał Sądu Duchownego we Lwowie. Szematyzm wseho duchowenstwa hreko-katotyćkoji Lwiwśkoji mytropotyczoji archieparchii na rik 1924, Lwiw 1924, s. V.

${ }^{299}$ Michalski Michał (1847-1907), właściciel fabryki powozów we Lwowie, 1880-1907 członek Rady Miejskiej Lwowa, 1889-1907 poseł do Sejmu Galicyjskiego, 1895-1905 wiceprezydent Lwowa, 1905-1907 prezydent miasta. Był związany ze Stronnictwem Narodowo-Demokratycznym. Za jego rządów Lwów osiągnął wysoki poziom rozwoju przemysłowo-handlowego. M. Tyrowicz, Michalski Michat, w: PSB, t. 20, red. zbior., Wrocław 1975, s. 596-597.

a List pisany na 1 stronicy czystego papieru formatu zeszytowego. W lewym górnym rogu obcą ręką niebieską kredką błędnie napisano: „Puzyna”.

a Powyżej obcą ręką niebieską kredką napisano nazwisko: „Teodorowicz” i ołówkiem liczbę: „23”. List pisany jest na pojedynczej, nieliniowanej kartce formatu A4. Brak miejsca wystawienia dokumentu. Znak wodny przedstawia zdobiony napis: „Myrle Mill Columbia Paper”.

300 Janowicz Krzysztof - właściciel restauracji we Lwowie, zamieszkały przy ul. Lelewela 3.

301 Diller Erich (1859-1926) - generał austriacki, 1915-1916 generał-gubernator Lublina, 1916-1917 gubernator generalny Galicji. Źródło: Eryk von Diller, www.wladcy.myslenice.net.pl/Polska/opisy/Eryk\%20 von\%20Diller.htm. Dostęp: 17 I 2017 r. 
Chodzi im o reaktywowanie rady miejskiej ${ }^{302}$. Mówiłem Janowiczowi, że bez porozumienia się z Tobą nic nie mogę w tej mierze zrobić. On na to rzekł, że w każdym razie mogę przecie przyjść i wypowiedzieć się.

$\mathrm{Na}$ tym stanęło, że będzie dziś u mnie o [godz.] 11-tej. Co z tym fantem zrobić? Nie mam niestety już czasu być u Ciebie i porozumieć się. Może więc mi napiszesz Swoje zdanie. Czy oni jednak mają człowieka na taką chwilę?303

Serdecznie Cię ściskam

Piątek, 23/VI [1]916

Twój J[ózef]

\section{Dokument 116}

\section{Carissime.$^{\mathrm{a}}$}

O [godz.] 6 1⁄2 będzie deputacja mieszczan u ciebie. Powiedziałem im, żeby już do mnie osobno nie szli, więc będą już u Ciebie. Głąbiński ${ }^{304}$ i Adam ${ }^{305}$ nie radzili nam an-

${ }^{302}$ Po wkroczeniu wojsk rosyjskich do Lwowa 3 IX 1914 r. działalność Rady Miejskiej została ograniczona do czynności poszczególnych komisji, głównie tzw. „komisji rozdawniczych”, zajmujących się akcją charytatywną. Po powrocie władz austriackich do Lwowa 22 VI 1915 r., namiestnik baron Erich Diller rozwiązał Radę Miejską 30 czerwca t. r. pod pretekstem nieobecności w mieście większości radnych, co uniemożliwiało jej funkcjonowanie. W to miejsce powołał komisarza rządowego - starostę Adama Grabowskiego z grupą 24 mężów zaufania, tworząc tzw. Radę Przyboczną. Reaktywowanie Rady Miejskiej nastąpiło dopiero 31 I 1918 r. na mocy reskryptu Namiestnictwa. Powstała wówczas 100-osobowa Tymczasowa Rada miasta Lwowa, kierowana nadal przez komisarza rządowego. J. Wołczański, Ksiąz Szczepan Szydelski, s. 265.

${ }^{303}$ Deputacja złożona z 5 osób, m.in.: Krzysztofa Janowicza, Ferdynanda Ohly, Józefa Neumanna i Michała Makowicza złożyła 23 VI 1916 r. wizytę również abp. Bilczewskiemu. Delegaci zadeklarowali wobec metropolity gotowość udania się do namiestnika z prośbą reaktywowania Rady Miejskiej. Nie mieli wprawdzie nadziei na pomyślny rezultat swych zabiegów, ale tym wystąpieniem chcieli przynamniej zaznaczyć swą troskę o dobro miasta. W spotkaniu uczestniczył również abp Teodorowicz. Zapewne delegaci nalegali, aby wraz z nimi udali się obaj hierarchowie do namiestnika, bowiem ci wymówili się od tego kroku zapewnieniem o braku jakichkolwiek szans na powodzenie misji. Obiecali wszakże wyjednanie delegacji audiencji w pałacu namiestnikowskim. AALK, bsygn., J. Bilczewski, Dziennik, s. 556-557.

a List pisany na 1 stronicy czystego papieru formatu kieszonkowego. W lewym górnym rogu obcą ręką niebieską kredką napisano: „Teodorowicz”, w prawym - ołówkiem liczbę: „29”.

${ }^{304}$ Głąbiński Stanisław (1862-1943), dr praw, w 1892 r. habilitował się z ekonomii społecznej, w 1892 r. prof. nadzwyczajny na Uniwersytecie Lwowskim, w 1895 r. prof. zwyczajny, 1899-1900 dziekan Wydziału Prawa i Umiejętności Politycznych, w roku akad. 1908/09 r. rektor uczelni, 1890-1892 zastępca redaktora „Gazety Narodowej”, 1902-1918 poseł do Rady Państwa, 1904-1918 poseł na Sejm Galicyjski, 1910-1918 poseł na Sejm Bukowiński. Związany był ze stronnictwem wszechpolskim, od 1905 r. należał do Stronnictwa Narodowej Demokracji, 1919-1928 zasiadał w Sejmie z ramienia Związku Ludowo-Narodowego, 28 V - 14 IX 1923 r. był ministrem Wyznań Religijnych i Oświecenia Publicznego, 1928-1935 senator. We wrześniu 1939 r. aresztowany przez Sowietów, zmarł w Moskwie. A. Galos, Gtąiński Stanistaw, w: PSB, t. 8, red. zbior., Wrocław-Kraków-Warszawa 1959, s. 102-105; J. Gołębiowski, Gtąbiński Stanistaw, w: Kto byt kim, s. 39.

305 Adam Ernest (1868-1926), dr praw, od 1890 r. pracownik redakcji „Nowej Reformy” w Krakowie, w 1892 r. założyciel Towarzystwa Szkoły Ludowej tamże, 1920-1926 prezes Zarządu Głównego. W 1896 r. powrócił do Lwowa; 1910-1926 dyrektor Galicyjskiego Ziemskiego Banku Kredytowego we Lwowie, 1915-1919 
gażować się w sprawie, której rezultat będzie z góry przesądzony, bo na to rząd się nie zgodzi. Można wszakże życzliwie ich przyjąć.

Do zobaczenia się tedy

Lwów, d[nia] 29 VI 1916

† J[ózef $]$

\section{Dokument 117}

Carissime?

Jeśli łaska, podjedź po mnie. O której to godzinie się zaczyna? Czy mam wziąć fiolety? Nie męcz się pisaniem i powiedz posłańcowi ustnie.

Ściskam Cię

poniedziałek, 16/X [1]916

Twój

\section{Dokument 118}

\section{Carissime?}

Po wczorajszej dyskusji, przyszedłem do przekonania, że będzie dobrze, jeśli i ja u niego (namiestnika) dziś będę.

Mogę Ci też któreś z odiozów ${ }^{306}$ pomóc wziąć. Mogę np. mówić o Maternie ${ }^{307}$, albo też o prezydencie skarbowej dyrekcji, naturalnie, jeśli tego chcesz. O której godzinie mam być? Pójdziemy wprawdzie osobno, ale może i dobrze będzie, jeśli jeden pójdzie za drugim.

Ściskam Cię serdecznie

Wtorek, 17/X [1]916

Józef

prezes Związku Stowarzyszeń Zarobkowych i Gospodarczych b. Dzielnicy austriackiej, założył Książnicę TSL we Lwowie, „Bursę Grunwaldzką TSL” i „Czytelnię Naukową dla TSL we Lwowie, 1896-1898 pełnił funkcję redaktora „Przeglądu Wszechpolskiego”, od 1902 r. członek redakcji „Słowa Polskiego”. W 1904 r. należał do współzałożycieli Stronnictwa Demokratyczno-Narodowego w Galicji, 1905-1926 członek Rady Miejskiej Lwowa, 1913-1918 poseł do Sejmu Galicyjskiego, od 1919 r. poseł do Sejmu RP, 1922-1926 senator. Z. Próchnicki. Adam Ernest, w: PSB, t. 1, s. 21-23.

a Obok niebieską kredką obcą ręką błędnie napisano nazwisko: „Puzyna”. Informacja zapisana jest na twardym papierze formatu wizytówki. Brak miejsca wystawienia dokumentu.

a List pisany na 1,5 stronicy czystego papieru formatu zeszytowego z wyciśniętym znakiem wodnym: „Margaret Mill Old Style”. W lewym górnym rogu strony tytułowej obcą ręką niebieską kredką napisano błędnie: „Puzyna”, w prawym - ołówkiem liczbę: „17”. Brak miejsca wystawienia dokumentu.

${ }^{306}$ Z łac.: odiosus - przykry; tu w znaczeniu trudnych i przykrych tematów.

307 Postać niezidentyfikowana. 


\section{Dokument 119}

\section{Carissime $!^{\mathrm{a}}$}

Zapomniałem Ci zwrócić uwagę na to, co wczoraj Vogel ${ }^{308}$ mówił. Z tego wynikało jasno, że już wiedzą w mieście, żeś odmówił Te Deum ${ }^{309}$ i że podałeś powody, dla których odmówiłeś. To rozgłoszenie utrudnia ogromnie nasze cofnięcie się, które wygląda na kapitulację wobec $\mathrm{NKN}^{310}$ i w ogóle na kapitulacji wobec ulicy. Dlatego choć rzecz sama w sobie mniejszej jest wagi, przez ten moralny wzgląd nabiera innego znaczenia zwłaszcza w tej sprawie, która będzie pierwszym krokiem do różnych podobnych prób.

Podałem Ci do rozważenia to, co mi się nasunęło na umysł. Zrób jak uważasz, a jakkolwiek zrobisz lojalnie pójdę za Tobą.

Ściskam Cię serdecznie

Twój Józef

\section{Dokument 120}

\section{Carissime ${ }^{\mathrm{a}}$}

Niedziela, 11/I [1]917

Miałem nadzieję być u Ciebie wczoraj, ale mi gardło moje przeszkodziło, chwyciło mnie silniej. Najzupełniej podzielam Twe zapatrywanie i sam od siebie mniej więcej to samo prawie tym panom powiedziałem, zastrzegając się tylko, że to moje zdanie o dalszym przebiegu i dalszym stadium sprawy uwiadomię Cię.

Tymczasem ściskam Cię serdecznie

Józef

Telegrafowałem Dillerowi, dowiedziawszy się o zranieniu jego syna i sądząc, że jest ciężkie. Rana atoli jest lekka.

a List pisany na 2 stronicach czystego papieru formatu zeszytowego z odciśniętym znakiem wodnym: „Margaret Mill Old Style”. W lewym górnym rogu karty tytułowej obcą ręką niebieską kredką napisano błędnie: „Puzyna”.

308 Vogel Aleksander - dr, współpracownik „Wieńca” i „Pszczółki” oraz redaktor „Dziennika Polskiego” i „Gazety Narodowej”, którą w 1890 r. zakupił; zamieszkały we Lwowie przy ul. Słowackiego 8. Prasa polska, passim.

${ }^{309}$ Abp Bilczewski celebrował uroczyste nabożeństwo w Bazylice Metropolitalnej ob. łac. we Lwowie 5 XI 1916 r. z okazji ogłoszenia manifestu przez cesarzy: niemieckiego Wilhelma II i austriackiego Franciszka Józefa. Dokument zapowiadał utworzenie „państwa samodzielnego z dziedziczną monarchią i konstytucyjnym ustrojem" na terenach polskich odebranych Rosji. Państwo to miało posiadać własną armię, ale manifest milczał na temat kwestii rządu i granic.

${ }^{310}$ NKN - Naczelny Komitet Narodowy utworzony 16 VIII 1914 r. w Krakowie, złożony z przedstawicieli wszystkich stronnictw politycznych. Obejmował on patronat polityczny nad przyszłymi legionami. Episkopat łaciński Galicji zachowując lojalność względem monarchii austro-węgierskiej, zdystansował się wobec NKN. Jedynie biskup pomocniczy lwowski Władysław Bandurski w odróżnieniu od pozostałych hierarchów manifestował pełne poparcie dla idei NKN.

a List pisany na 1 stronicy czystego papieru formatu zeszytowego. Brak miejsca wystawienia dokumentu. W lewym górnym rogu karty tytułowej obcą ręką niebieską kredką napisano błędnie: „Puzyna”. 


\section{Dokument 121}

19/II [1]917

\section{Carissime $!^{\text {a }}$}

Obiecałeś był wstawić się za Tyszkowskim ${ }^{311}$, by go z tytułu zarządcy majątku tymczasowo ze służby zwolniono. Otóż jego sprawa jest obecnie aktualnie ${ }^{\mathrm{b}}$, powołano go przed paru dniami, a że nie śmieją interesanci naprzykrzać $\mathrm{Ci}$ się przypominaniem, więc mnie o to proszą. Chodzi o urgens ministerium wojny. Czyś dostał list od Sapiehy? Mówił mi Komusiewicz ${ }^{312}$, że Sapieha do Ciebie list dał; do mnie nic nie napisał.

Ściskam Cię serdecznie

Józef

\section{Dokument 122}

\section{Carissime $^{\mathrm{a}}$}

Za przerwanie Ci, gdy mówiłeś do Pelczara, wierzaj mi zupełnie impulsywne i bezwiedne, najmocniej Cię przepraszam i będę na to w przyszłości uważał. Możeś o tyle i Ty się do tego przyczynił, gdyś mi kładł na serce uwypuklenie wobec Pelczara momentu politycznego. Warunki Bobrzyńskiego w zasadzie en $b l o c^{313}$ uznaję wszystkie: to jest status quo ante ${ }^{314} \mathrm{i}$ sądzę, że nie można w tym pójść za daleko. Tylko co do taktyki z nim się nie godzę. On chciałby lecieć w objęcia rządowi. Miałby wysuwać kwestię Galicji, ja tymczasem przeciwstawiłem temu dążeniu w ostatnim przemówieniu:

1) Bezcelowość, bo koło polskie dziś na żadne układy nie pójdzie i każdego układającego się zbojkotuje;

2) Brak uwzględnienia psychologii pokrzywdzonego, który za prędko sam zaczyna myśleć o układach.

I właśnie dlatego Pelczara zapraszałem do Lwowa, bo się lękałem, że nasze dorywcze przedstawianie mu rzeczy wywołane brakiem czasu może go w błąd wprowadzić. Co do Sapiehy i Czartoryskiego, to pytałem ich parokrotnie, czy nie poszedłem w mym przemówieniu za daleko „na prawo”, a oni mnie zapewniali, że nie, bom jasno określił warunki, pod jakimi na rzecz samą w sobie słuszną się zgodzę. Dziękuję Ci, że Twój list pozwala mi uważać za epizod przypadkowy, który w niczym naszego stosunku nie

a List pisany na 1 stronicy czystego papieru formatu zeszytowego z odciśniętym znakiem wodnym: „Margaret Mill Astra”. Brak miejsca wystawienia dokumentu. W lewym górnym rogu niebieską kredką obcą ręką napisano błędnie: „Weber”.

311 Postać niezidentyfikowana.

b Zapis zgodny z oryginałem; poprawnie powinno być: aktualna.

${ }^{312}$ Komusiewicz Franciszek (1881-1936), pochodził z polskiej rodziny rzymskokatolickiej, przeszedł na obrządek ormiańskokatolicki i w 1910 r. przyjął święcenia kapłańskie: 1910-1919 wikariusz ormiańskiej katedry we Lwowie i sekretarz abp. Teodorowicza, 1919-1936 proboszcz parafii ormiańskiej w Stanisławowie, 1928-1936 także administrator w Horodence. T. Zaleski, Stownik, s. 63-64.

a List pisany na 3 stronicach czystego papieru formatu zeszytowego. W lewym górnym rogu niebieską kredką obcą ręką napisano błędnie: „Weber”.

${ }^{313}$ Fr.: w całości.

314 Łac.: stan wcześniejszy, pierwotny. 
zmąci i proszę Cię tylko, zwróć mi zawsze uwagę, jeśli Cię coś uderzy w mym przemówieniu czy zachowaniu.

Serdecznie Cię pozdrawiam i ściskam

Lwów, d[nia] 21/II [1]918

Twój Józef

Dokument 123

Carissime! $^{\mathrm{b}}$

$[\ldots]^{\mathrm{a}}, 26 /$ VIII [1]918

Miałem się przypisać do Ciebie na ostatnim liście Sapiehy, ale on szybciej z listem umknął niż się opatrzyłem. „Żałuj felek” ... żeś tu nie przybył. Pobyt tu nam wcale dobrze robi, czas z początku był kiepski, ale teraz piękny. Sapieha wraca już w tym tygodniu, mnie jednak zatrzymuje kuracja jeszcze przez dni kilka.

Radziliśmy z Sapiehą nad zjazdem biskupów w Częstochowie i on Cię prosi byś odpisał Kakowskiemu, że przyjedziemy, ale wolelibyśmy by miejscem zjazdu była Warszawa, a nie Częstochowa. Czasy są tak wyjątkowe, że skoro się raz dostało paszport do Królestwa, to już warto by być w Warszawie. Zresztą sama konferencja biskupów inaczej pójdzie, skoro będziem[y] mieć kontakt w Warszawie z kapłanami i w ogóle skoro będziemy patrzeć na sprawy w tym i owym oświetleniu.

Chodziłoby tylko o to, by z arcybiskupa zrzucić brzemię obiadów. Nie wiem oczywiście, czy Kakowski nie będzie się bał zjazdu w Warszawie, ale poddaję Ci tę myśl Sapiehy, do której też się zupełnie przyłączam. Jakże Ci Twoje Tusculum posłużyło? Lecz zobaczę się niedługo z Tobą, a wtedy sam będę miał sposobność o tym się przekonać.

Tymczasem najserdeczniej Cię ściskam

Twój Józef

Po napisaniu mego listu, napisał Ci Sapieha od siebie i list jego dołączam.

\section{Dokument 124}

Kochany Księże Arcybiskupie!

Lwów, 8/X [1]918

Zgłosili się do mnie Głąbiński, Adam, Dąbrowski ${ }^{315}$ z prośbą, że chcą omówić sytuację. Zaprosili się na dzisiaj wyrażając przy tym prośbę bym zaprosił i Ciebie. Byłem

\footnotetext{
a Wyraz nieczytelny.

b List pisany na 2 stronicach czystego papieru formatu zeszytowego. W lewym górnym rogu strony tytułowej niebieską kredką obcą ręką napisano błędnie: „Weber”.

a Obok obcą ręką niebieską kredką napisano nazwisko: „Teodorowicz”. List pisany jest na pojedynczej, nieliniowanej kartce formatu zeszytowego. Papier nie posiada znaku wodnego.

315 Dąbrowski Stefan Tytus (1877-1947), dr wszechnauk lekarskich, habilitował się na Uniwersytecie Lwowskim i tam od 1913 r. był prof. nadzwyczajnym na Wydziale Lekarskim. W 1918 r. brał udział
} 
u Ciebie rano, ale Cię nie zastałem, myślałem, że Cię odwiedzę z powrotem z Rady Szkolnej, lecz było już za późno, dlatego zapraszam Cię już listownie na dziś na 5 po obiedzie.

Najserdeczniej Cię pozdrawiam i ściskam

Teodorowicz

\section{Dokument 125}

\section{Carissime $!^{\mathrm{a}}$}

Praca na dzisiaj jest jednak trudniejszą jak myślałem, dlatego muszę koniecznie z piórem w ręku [... $]^{\mathrm{b}}$ rano. Proszę Cię więc już rano nie posyłaj po mnie koni. Aby zgorszenia nie było dam znać do gazet, że miałem nabożeństwo za Polskę o [godz.] 9. Po obiedzie może mi się uda już opanować do tyle materiał ${ }^{316}$, że będę na procesjii ${ }^{317}$; dlatego proszę Cię o łaskawe przybycie.

Ściskam serdecznie

Józef

\section{Dokument 126}

Kochany Księże Arcybiskupie!a

w obronie Lwowa. od 1919 r. delegat rządu I. Paderewskiego przy misji koalicyjnej gen. J. Berthélemy ds. Małopolski Wschodniej: 1920-1921 podsekretarz stanu w MSZ. Poseł do Sejmu 1922-1935 z ramienia Związku Ludowo-Narodowego, 1928-1935 wiceprezes Stronnictwa Narodowego, 1921-1939 i 1945-1947 prof. Uniwersytetu Poznańskiego. G. Mazur, Dąbrowski Stefan Tytus, w: Kto byt kim, s. 92; J. Malinowski, Stefan Dąbrowski (1877-1947). Biografia polityczna, Poznań 2014, passim.

a Powyżej na lewo błędnie napisano obcą ręką niebieską kredką nazwisko: „Weber”. List pisany jest na pojedynczej, nieliniowanej kartce formatu zeszytowego. Brak znaku wodnego.

b Dwa wyrazy nieczytelne.

316 Abp Teodorowicz wygłosił prawdopodobnie w ratuszu mowę nawiązującą do enuncjacji Rady Regencyjnej. AALK, bsygn., J. Bilczewski, Dziennik, s. 632.

${ }^{317}$ Z okazji ogłoszenia proklamacji Rady Regencyjnej 7 X 1918 r. o „utworzeniu niepodległego państwa, obejmującego wszystkie ziemie polskie z dostępem do morza", abp Bilczewski zorganizował 20 X $1918 \mathrm{r}$. we Lwowie procesję pokutno-błagalną. Jej trasa wiodła z kościoła oo. Bernardynów do Bazyliki Metropolitalnej ob. łac. Uczestniczyło w niej „przynajmniej 20000 ludzi. Cały Lwów się poruszył”; brał w niej udział także abp Teodorowicz. Kazanie przed katedrą wygłosił o. Stanisław Sopuch SJ. W katedrze sumę pontyfikalną celebrował metropolita Bilczewski, a po jej zakończeniu ks. kanonik Henryk Badeni odczytał z ambony proklamację Rady Regencyjnej. Metropolita zanotował ówczesne nastroje: „Wrażenie ogromne. [...]. Cały kościół odśpiewał zwrotkę «Boże coś Polskę». Bardzo poważny nastrój”. AALK, bsygn., J. Bilczewski, Dziennik, s. 632-633.

a Powyżej niebieską kredką nazwisko „Bilczewski” oraz ołówkiem liczba „20”. List pisany jest na podwójnej, nieliniowanej, żółtej kartce formatu zeszytowego. Papier nie posiada znaku wodnego. Brak miejsca wystawienia dokumentu. 
Proszę Cię, byś był tak dobry i wziął mnie na procesję $e^{318}$. Serdecznie Cię pozdrawiam Józef

Niedziela, 20/X [1]918

\section{Dokument 127}

Jadę jutro rano o [godz.] 8. Proszę Cię bardzo o konie na [godz.] 7, bo mój koń chory, a znikąd dziś już koni nie dostanę. Bardzo przepraszam. Ściskam Cię najserdeczniej.

\section{Dokument 128}

Kochany Księże Arcybiskupie! ${ }^{a}$

Piszę tylko szkicując rzecz. Wszyscy tu odczuwamy potrzebę jakiegoś pogodzenia się z rusinami ${ }^{\mathrm{b}}$, a to dlatego, że inaczej grozi rzeź, mord i zniszczenia we wschodniej Galicji ${ }^{319}$. Tak czy owak, ani oni, ani my, tylko kongres będzie rozstrzygał o wszystkim i idzie więc o modus vivendi ${ }^{320}$ na ten przejściowy czas. Pójdź więc do metropolity ${ }^{321}$ i zapytaj go o warunki, jakie by rusini postawili stronie polskiej, oczywiście dotyczące tylko tego przejściowego czasu. Te warunki by tu poddamy i omówimy z tymi, którzy tu rządzą i zaraz pośle się odpowiedź.

Tu u nas bardzo smutno! W Krakowie napędzono komisarza warszawskiego Czartoryskiego niby pod pozorem, że książę, a głównie dlatego, że komisja likwidacyjna chciała sama władzę wziąć w rękę. I wzięła, i stworzyła własny rząd. Drugi rząd radykalny tworzy się w Lublinie. W Warszawie walka znowu jest między radą regencyjną a rządem ${ }^{322}$. Tak więc mamy 3 rządy, względnie już 4! Tak zaczynamy nasze dzieje. Czartoryskiego obaliła demokracja narodowa. A więc waliła we własny swój rząd.

318 Zob. list 125, przypis 314 niniejszej części.

a Tekst napisany na bilecie wizytowym z nadrukiem: „Arcybiskup Teodorowicz”. Brak tytulatury, autografu autora, datacji i miejsca wystawienia dokumentu. W lewym górnym rogu ręką abp. Bilczewskiego nota: „1/XII [1]918”.

a Powyżej niebieską kredką napisane jest nazwisko „Teodorowicz” i ręką abp. Bilczewskiego data: „6 XI 1918". List pisany jest na pojedynczej, nieliniowanej kartce formatu zeszytowego.

b Zapis zgodny z oryginałem - tak konsekwentnie dalej; poprawnie powinno być: Rusinami.

${ }^{319}$ List pisany z Krakowa, dokąd abp Teodorowicz wyjechał 30 X 1918 r. na wezwanie bp. Sapiehy. Tymczasem we Lwowie nocą z 31/1 XI 1918 r. Ukraińcy przejęli władzę, co dało początek wojnie ukraińsko-polskiej.

${ }^{320}$ Łac.: metoda układania stosunków wzajemnych.

${ }^{321}$ Mowa o lwowskim metropolicie unickim abp. Andrzeju Szeptyckim.

${ }^{322}$ Dnia 31 X 1918 r. w Krakowie objęła władzę Polska Komisja Likwidacyjna złożona z przedstawicieli wszystkich stronnictw, z wyjątkiem konserwatystów. W Warszawie 3 listopada t. r. rząd Józefa Świerzyńskiego ogłosił manifest, w którym usiłował odciąć się od Rady Regencyjnej, deklarując współpracę z ludowcami i socjalistami. Został więc przez nią zdymisjonowany. W Lublinie zaś powstał Tymczasowy Rząd Ludowy Republiki Polskiej pod przewodnictwem Ignacego Daszyńskiego z przedstawicielami PPS, PPSD i ludowców. 
Bądź tak dobry i doręczyć każ list tu załączony Matce ${ }^{323}$. Piszę oczywiście po wspólnym porozumieniu się z biskupem. Żal nam bardzo was i miasta. Biedne! Co też ono nie przeżywa! Modły ślę, by Bóg odwrócił nieszczęścia.

Ściskam serdecznie, oddany $\mathrm{Ci}$

Józef

Poślij też memu bratu ${ }^{324}$ plany tu dołączone.

Kraków, wtorek 6/XI [1]918

Dołączam Ci list mój pisany do Skarbka ${ }^{325}$, który po przeczytaniu odeślij memu bratu z poleceniem, by go dał Dąbrowskiemu. Niechaj oni wiedzą, co o Sk[arbku] sądzić mając.

\section{Dokument 129}

\section{Carissime! ${ }^{\mathrm{a}}$}

Serdecznie Ci dziękuję za konie i żegnam Cię. Niestety, nie jedziesz ${ }^{326}$. Ale sam to do pewnego stopnia rozumiem, zwłaszcza po wczorajszej bytności Pinińskiego, który się gwałtem tego domagał, bym i ja pozostał, tak że dopiero musiałem tłumaczyć mu i umowę z Tobą, i list pasterski wyciągać na tapet zanim go przekonałem i uspokoiłem, iż jest potrzebne, by jeden z nas przynajmniej pojechał. Więc są oni i niepewni, i niespokojni. Gdyby jednak do soboty, jaka nagła i szczęśliwa zmiana była, to choćby w chwili ostatniej przybywaj.

Twoje kuzynki były o Ciebie bardzo niespokojne i przychodziły do mnie w Krakowie pytać się o Ciebie.

Najserdeczniej Cię pozdrawiam i ściskam

Lwów, 6/XII [1]918

Józef

${ }^{323}$ List adresowany do matki hierarchy - Gertrudy z Ohanowiczów Teodorowiczowej (1838-1930), polskiej Ormianki, córki Dawida Ohanowicza i Gertrudy Mikołajewicz, a żony Grzegorza Teodorowicza.

${ }^{324}$ Mowa o Michale Teodorowiczu zamieszkałym we Lwowie.

${ }^{325}$ Skarbek Aleksander (1874-1922), prawnik, członek Ligi Narodowej, 1908-1914 poseł do Sejmu Galicyjskiego, 1909-1918 poseł do parlamentu wiedeńskiego. Po wybuchu I wojny światowej wchodził w skład Centralnego Komitetu Narodowego, przewodniczył wydziałowi wojskowemu Sekcji Wschodniej NKN. W 1915 r. zmuszony do opuszczenia Galicji wyjechał do Lozanny, skąd powrócił do kraju w 1918 r. Uczestniczył w walkach z Ukraińcami o Przemyśl i Lwów 1918 r. Był posłem do Sejmu Ustawodawczego. C. Brzoza, Skarbek Aleksander, w: Kto Byt kim, s. 427.

c U dołu nota ręką abp. Bilczewskiego: „Otrzymałem list dopiero 23/11 popołudniu [sic!]. † Józef”.

a Powyżej obcą ręką na lewo niebieską kredką błędnie napisano nazwisko: „Bilczewski”. Powyżej na prawo ręką abp. Bilczewskiego nota: „List Ks. Arcyb[iskupa] Teodorowicza przed wyjazdem do Warszawy”. List pisany jest na podwójnej i nieliniowanej kartce formatu zeszytowego. Brak znaku wodnego.

${ }^{326}$ Abp Teodorowicz wyjechał do Krakowa i Warszawy z misja szukania pomocy dla okupowanego przez Ukraińców Lwowa. AALK, bsygn., J. Bilczewski, Dziennik, s. 676. 


\section{Dokument 130}

\section{Carissime $^{\text {Ia }^{2}}$}

Ślę Ci najszczersze, najgorętsze życzenia świąteczne. Myślą przebywam często u Ciebie, bo znowu tyle tam w biednym Lwowie troski i ucisku. Ja tu się krzątam jak mogę, by Lwowowi pomóc. Byłem po porozumieniu się z Sapiehą u Rattiego ${ }^{327}$ prosząc, by osiągnął interwencję u Ojca Św[iętego] na rzecz Lwowa. Ojciec Św[ięty] miałby napisać do Szeptyckiego, by nacisnął na Szeptyckiego, aby ze swej strony uczynił wszystko, co możliwe, by położyć kres rozlewowi krwi. Ratti obiecał mi, że to uczyni, ale dodał, że dla formy podobne pismo będzie wystosowane i do Ciebie ${ }^{328}$. Następnie otrzymałem od niego wiadomość, iż już się odniósł do papieża. Następnie udałem się do Grabskiego ${ }^{329}$ ażeby na koalicji wymógł oświadczenie, które by przesłano rusinom ${ }^{\mathrm{b}}$. W tym telegramie koalicji do rusinów byłoby wyraźnie zaznaczone, że zabór Lwowa w niczym nie przesądzi sprawy. Rozstrzygającym jednak dla Lwowa będzie przysłanie wojsk Hallera ${ }^{330}$.

a Powyżej na lewo błędnie napisane niebieską kredką nazwisko: „Puzyna”. Z prawej strony ręką abp. Bilczewskiego adnotacja: „List z Warszawy otrzymałem 9/I [1]919”. List pisany jest na dwóch podwójnych, liniowanych kartkach formatu zeszytowego bez znaków wodnych. Brak miejsca wystawienia dokumentu i datacji.

${ }^{327}$ Ratti Achilles/Pius XI (1857-1939), włoski duchowny, święcenia kapłańskie w 1879 r.; 1882-1888 wykładowca w Seminarium Duchownym w Mediolanie, 1888-1907 pracownik Biblioteki Ambrosiana tamże, od 1907 r. prefekt tej instytucji, 1912-1914 proprefekt Biblioteki Watykańskiej, 1914-1918 prefekt tamże; od 25 IV 1918 r. wizytator apostolski w Polsce i Litwie. Dnia 6 VI 1919 r. został nuncjuszem apostolskim w Polsce, 3 VII t. r. mianowany arcybiskupem tytularnym; 20 IV 1920 r. Stolica Apostolska zleciła mu obowiązki wysokiego komisarza kościelnego na Górnym Śląsku. Polskę opuścił 4 VI 1921 r., 13 VI t.r. kreowany arcybiskupem Mediolanu i kardynałem, 6 II 1922 r. wybrany papieżem; przyjął imię Piusa XI. G. Schwaiger, Pius XI, w: LThK, Bd. 8, herausg. von J. Höfer, K. Rahner, Freiburg 1986, kol. 540-542.

${ }^{328}$ Wspomniane pismo w imieniu papieża Benedykta XV wystosował 27 XII 1918 r. ks. Achilles Ratti do abp. Bilczewskiego i abp. Szeptyckiego w sprawie poszukiwania rozwiązań pokojowych w toczącej się wojnie. Pełny tekst enuncjacji zob.: J. Wołczański, Nieznana korespondencja arcybiskupów metropolitów lwowskich Józefa Bilczewskiego z Andrzejem Szeptyckim w czasie wojny polsko-ukraińskiej 1918-1919, Lwów-Kraków 1997, s. 143-148.

${ }^{329}$ Grabski Stanisław (1871-1949), polski ekonomista i polityk, 1905-1910 prof. Akademii Rolniczek w Dublanach k. Lwowa, 1910-1939 prof. Uniwersytetu Lwowskiego, członek Stronnictwa Narodowo-Demokratycznego w Galicji i Związku Ludowo-Narodowego, 1919-1927 poseł do Sejmu RP, w l. 1923, 1925, 1925-1926 minister Wyznań Religijnych i Oświecenia Publicznego, w 1925 r. negocjator konkordatu Stolicy Apostolskiej z RP, 1939-1941 więziony przez Sowietów w Moskwie, 1942-1945 przewodniczący Rady Narodowej w Londynie, 1945-1949 przebywał w PRL-u: 1947-1949 prof. ustrojów społecznych na Uniwersytecie Warszawskim. Grabski Stanistaw, w: Kto byt kim, s. 40.

b Zapis zgodny z oryginałem; poprawnie powinno być: Rusinom.

${ }^{330}$ Haller Józef (1873-1960), absolwent szkół wojskowych, 1895-1912 służył w armii austriackiej, 19121914 współorganizator skautingu i Drużyn Sokolich w Galicji, od 1914 r. służył w Legionach Polskich, 1918-1919 przebywał we Francji obejmując dowództwo nad formującymi się tam polskimi oddziałami; po powrocie w 1919 r. do Polski był dowódcą na frontach: Galicyjskim, Południowo-Wschodnim, Południowym, Pomorskim i Północno-Wschodnim. Od 1920 r. pełnił funkcję generalnego inspektora artylerii, przechodząc w stan spoczynku w 1926 r.; 1922-1923 poseł na Sejm z mandatu endecji, 1920-1923 przewodniczący ZHP; działał w Stronnictwie Narodowym, był związany z Frontem Morges (1936-1937), od 1937 r. ze Stronnictwem Pracy, 1939-1943 w rządzie gen. W. Sikorskiego piastował urząd ministra bez teki. Zmarł w Londynie. G. Mazur, Haller Józef, w: Kto byt kim, s. 125; K. Kaczmarski, W. J. Muszyński, R. Sierchuła, Generat Józef Haller 1873-1960, Warszawa 2017, passim. 
One na pewno idą, a Haller tuż po wylądowaniu ma spieszyć wprost na odsiecz Lwowa. Byleście do tego czasu wytrzymali.

Ja tu zostaję jak najdłużej, bo tu mogę daleko więcej dla Lwowa robić niźli tam, gdzie Ty i tak jesteś, więc ja zupełnie jestem we wszelkiej akcji zbędny.

Następnie mam zleconą przez konferencję biskupów sprawę, by wraz z Tobą i Hallerem opracować sprawę stosunku Kościoła do państwa. Wobec tego, że ani Ty, ani Dalbor $^{331}$ nie będziecie, spoczywa to na mnie. Do tych potrzeb przyłącza się jeszcze jedna, która się wyłoniła w dniach ostatnich. Oto przybyła do mnie deputacja z Siedlec z tym, iż tam na zjeździe delegatów uchwalono jednogłośnie postawić moją kandydaturę na posła. Sprawa ta była dyskutowana w zasadzie na konferencji biskupów gdzie wyrażono życzenie, by biskupi byli w sejmie, o ile ich wybór łatwo przejdzie. Co do mnie, to kandydatura moja jest pewna ${ }^{332}$. Wprawdzie nie mogłem odmówić, ale wprost mnie przeraża rzucenie się w wir szalony i mętny polityczny i ścieranie się ciągłe w tych codziennych utarczkach politycznych. Ale ostatecznie iść się musi. Oświadczyłem im, że mogę iść tytko na pewne, o czym mnie zapewniono, nie mogę też formalnie kandydować. Trudności mam jednak mimo to wszystko bardzo poważne nawet techniczne i inne, jak z mieszkaniem, pobytem tu i we Lwowie, etc. Więc niby idę, ale i jakby nie idę. Ale dosyć o tym.

Ściskam Cię serdecznie, a modląc się gorąco o Ciebie i polecając się Twej pamięci, życzę Ci z Nowym Rokiem wszystkiego najlepszego

Twój Józef

\section{Dokument 131}

\section{Carissime! ${ }^{\mathrm{a}}$}

Jestem po prostu w obawie, czy moje listy do Ciebie nie giną ${ }^{333}$. Pisałem Ci 3. W jednym doniosłem, że Ratti mi pisał o pozwoleniu z Rzymu ${ }^{334}$ w sprawie biskupa

${ }^{331}$ Dalbor Edmund (1869-1926), święcenia kapłańskie w 1893 r. w Rzymie dla archidiec. poznańskiej, dr prawa kanonicznego, 1894-1899 kanclerz Kurii Biskupiej w Poznaniu i wykładowca w miejscowym Seminarium Duchownym, 1899-1915 pełnił różne funkcje kościelne i administracyjne w Gnieźnie. Dnia 30 VI 1915 r. prekonizowany arcybiskupem gnieźnieńskim i poznańskim, 15 XII 1919 r. mianowany kardynałem; był członkiem rzymskiej Kongregacji Soboru, Obrzędów i Seminariów Duchownych. Działał na rzecz umocnienia niepodległego państwa polskiego, zainicjował opiekę duszpasterską nad emigracją, rozwijał akcję oświatową i charytatywną. P. Nitecki, Biskupi, s. 45; M. Banaszak, Dalbor Edmund w: EK, t. 3, red. zbior., Lublin 1985, kol. 976-977.

${ }^{332}$ Abp Teodorowicz piastował mandat poselski do Sejmu Ustawodawczego w 1. 1919-1922.

a Po lewej obcą ręką niebieską kredką napisano błędnie nazwisko: „Puzyna”. List pisany jest na pojedynczej, nieliniowanej kartce formatu zeszytowego. Brak datacji i znaku wodnego.

${ }^{333}$ Istotnie, chyba listy te nie docierały do rąk adresata - trwała wówczas wojna ukraińsko-polska - bowiem nie zachowały się one w kolekcji korespondencji zgromadzonej przez abp. Bilczewskiego.

${ }^{334}$ Ks. A. Ratti informował lwowskiego metropolitę łacińskiego, że może konsekrować ks. Bolesława Twardowskiego (1860-1944) na biskupa pomocniczego archidiecezji lwowskiej bez bulli papieskiej. AALK, bsygn., J. Bilczewski, Dziennik, s. 688. 
Twardowskiego ${ }^{335}$. Kartkę Rattiego adresowaną do mnie odesłałem Sapieże z prośbą, by $\mathrm{Ci}$ ją przekazał. Owe drugie listy zawierały wyjaśnienie, co do adresu Ojca Św[iętego] do was $^{336}$. Piszę ostrożnie i krótko nie mając pewności, czy me listy dochodzą do Ciebie i dlatego na razie urywam. Tu się robi, co tylko można. Na konsekrację biskupa Twardowskiego ${ }^{337}$ niestety nie będę mógł żadną miarą przybyć, bo mam być w tym czasie $\mathrm{w}$ Siedlcach u biskupa ${ }^{338} \mathrm{w}$ sprawach związanych z mym mandatem i biskup ludzi pozapraszał, tak że się to zawrócić nie da. Prócz tego są inne niezmiernie doniosłe sprawy o których pisać tu nie mogę.

Ściskam Cię najserdeczniej

Warszawa, czwartek

Twój Józef ${ }^{\mathrm{b}}$

\section{Dokument 132}

\section{Carissime $^{\mathrm{a}}$}

Za listy Ci dziękuję serdecznie. Tak wciąż jestem myślą z Wami! Czegóż Ty nie przechodzisz! Rozumiem, te nerwy idą w strzępy. Nie mogę Ci pisać tyle, ile bym chciał. Powody zrozumiesz. To pewna, że nie militarna pomoc, ale li tylko polityczna może jeszcze poradzi. Rozw[adowski] ${ }^{339}$ zbabrał wszystko. Bądź jednak o tyle spokojny, że tu się robi wszystko i po ludzku mówiąc rzeczy są na dobrej drodze. Mieliśmy tu zamach,

335 Twardowski Bolesław (1864-1944), święcenia kapłańskie w 1886 r. we Lwowie, dr prawa kanonicznego, dr honoris causa Uniwersytetu Jana Kazimierza we Lwowie, 1895-1901 kanclerz Kurii Metropolitalnej we Lwowie, 1902-1918 proboszcz parafii w Tarnopolu, 1918-1923 biskup pomocniczy archidiecezji lwowskiej, 1923-1944 biskup ordynariusz tamże. G. Chajko, Arcybiskup Bolesław Twardowski (1864-1944). Metropolita lwowski obrzadku tacińskiego, Rzeszów 2010, passim.

336 Por. list 130 niniejszej części.

${ }^{337}$ Konsekracja miała miejsce 12 I 1918 r. w Bazylice Metropolitalnej ob. łac. we Lwowie. W ceremonii uczestniczyli: abp Bilczewski, bp Leon Wałęga (Tarnów), bp Karol Józef Fischer (Przemyśl). Z powodu trwającej wojny i panujących antyukraińskich nastrojów we Lwowie pominięto w zaproszeniach hierarchię greckokatolicką. Podczas uroczystości słychać było odgłosy walki, nic więc dziwnego, że katedra świeciła pustkami. AALK, bsygn., J. Bilczewski, Dziennik, s. 701.

${ }^{338}$ Biskupem podlaskim w l. 1918-1939 był Henryk Przeździecki (1875-1939), sekretarz Konferencji Episkopatu Polski.

b Na prawo dopisek ręką abp. Bilczewskiego: „Kartkę tę od Ks. Arc[ybiskupa] Teodor[owicza] z Warszawy otrzymałem 18/1 [1]919; wysłana zdaje się 16/I".

a Obok niebieską kredką obcą ręką błędnie napisano nazwisko: „Puzyna”. List pisany jest na pojedynczej, nieliniowanej kartce formatu zbliżonego do A4. Brak miejsca wystawienia dokumentu, datacji i znaku wodnego.

339 Rozwadowski Tadeusz (1866-1928), generał broni, 15 XI 1918 - 19 III 1919 r. dowódca wojsk polskich w walce z Ukraińcami na terenie Małopolski Wschodniej, następnie szef Polskiej Misji Wojskowej w Paryżu, 1920-1921 generalny inspektor kawalerii, 1926-1927 więziony w Warszawie i Wilnie. W 1927 r. przeszedł w stan spoczynku; zmarł w Warszawie. G. Mazur, Rozwadowski Tadeusz, w: Kto byt kim, s. 139-140. 


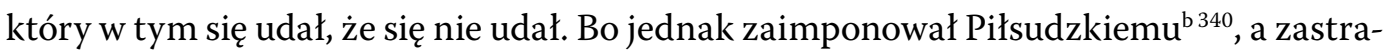
szył „towarzyszy”. A dobrze znów, że się nie udał, bo jest spokój. Odetchnęliśmy nareszcie po ustąpieniu tej bandy ${ }^{341}$. Biedny Paderewski ${ }^{342}$ przepracowany i przemęczony. Nie mam pojęcia jak on to wytrzyma. Chodzę do niego od czasu do czasu w sprawach, których się domyślasz. Cóż, kiedy dopiero teraz poczęto w ogóle o Lwowie myśleć. Tamci w ostatniej jeszcze chwili myśleli o oddaniu Lwowa. Stąd tyle opóźnienia i tak im literalnie nic nie można było wykołatać. Jak wybory wypadną, tego w ogóle nikt przewidzieć nie umie. Warszawa jeszcze i teraz dzieli się na partie i partie, zamiast skupić w jedno.

Robiłem objazd po Siedlcach i powiatach okolicznych i kazałem z ambony unikając wszelkich wieców. Przyznasz, że to pasztet nie lada wleźć w taki sejm! Jeszcze mnie tu traktują biskupstwem polowym. Ociągam się jak mogę, bo to doprawdy przechodzi moje i tak nietęgie siły. Te kapelany biorą pensję i używają warszawskich swobód, a młodzież na froncie ginie bez spowiedzi, bo nie ma księdza! Rozprzężenie straszne i rośnie z dnia na dzień. Gall ${ }^{343}$ nie chce się tego podjąć. Bandurski zaś agituje za sobą u Piłsudzkiego. Twoje listy pisane do niego są w ministerstwie spraw zagranicznych naturalnie przez niego podane by wykazać, że jest ofiarą. Piłsudzki poza Rattim i biskupami pisał za nim do Rzymu. Ratti, Szeptycki, Paderewski namawiają mnie na to. Sapieha mi jednak bardzo odradza. Może mnie z tych opresji wyratuje sam Piłsudzki, który będzie bardzo nierad $z$ tej kombinacji ${ }^{344}$. Wałęga sobie kpi ze mnie. Przyznam Ci się, że mam

b Zapis zgodny z oryginałem - tak konsekwentnie dalej; poprawnie powinno być: Piłsudskiemu.

340 Piłsudski Józef (1867-1935), polski polityk, 1919-1922 Naczelnik Państwa, od 1920 r. marszałek Polski, 1922-1923 szef sztabu Generalnego, 1926-1935 minister spraw wojskowych i generalny inspektor Sił Zbrojnych, 1926-1928 i 1930 r. premier. Pitsudski Józef, Kto byt kim, s. 16.

${ }^{341}$ Nocą 4/5 I 1919 r. grupa spiskowców na czele z Marianem Januszajtisem, Eustachym Sapiehą i Jerzym Zdziechowskim dokonała w Warszawie próby prawicowego zamachu stanu. Nie powiódł się on wprawdzie, ale Piłsudski spowodował ustąpienie szefa rządu socjalisty Jędrzeja Moraczewskiego i powierzył misję sformułowania nowego rządu Ignacemu Paderewskiemu. Dnia 16 I 1919 r. objął on stanowisko premiera rządu koalicyjnego, złożonego z reprezentantów endecji, stronnictw centrum, PPS i ludowców.

${ }^{342}$ Paderewski Ignacy (1860-1941), po studiach muzycznych w Warszawie, Berlinie i Wiedniu rozpoczął światowe koncerty fortepianowe, propagując zarazem ideę niepodległości Polski. Od 1917 r. należał do Komitetu Narodowego Polskiego w Paryżu; w okresie 16 I - 9 XII 1919 r. pełnił funkcję premiera i ministra spraw zagranicznych polskiego rządu; w 1920 r. wyjechał do Szwajcarii, a rok później do USA. Utrzymywał kontakty polityczne w latach 30 . XX w. z emigracyjnymi działaczami opozycyjnymi gromadzącymi się w jego willi w Morges („front Morges”). W 1939 r. objął przewodnictwo Rady Narodowej; w 1940 r. wyjechał do USA, zmarł w Nowym Jorku. J. Gołębiowski, Paderewski Ignacy, w: Kto byt kim, s. 60.

${ }^{343}$ Gall Stanisław (1865-1942), święcenia kapłańskie w 1887 r. w Warszawie, był duszpasterzem, wykładowcą i rektorem Seminarium Duchownego w Warszawie oraz kanonikiem Kapituły Katedralnej tamże. Dnia 29 VII 1918 r. mianowany biskupem pomocniczym warszawskim oraz 5 II 1919 r. pierwszym biskupem polowym Wojska Polskiego; z tej ostatniej funkcji zrezygnował 16 II 1933 r., po czym otrzymał godność arcybiskupa tytularnego Carpathus, 1939-1940 wikariusz generalny i kapitulny archidiecezji warszawskiej, 1940-1942 administrator apostolski tamże. P. Nitecki, Biskupi, s. 62.

${ }^{344}$ Bp Władysław Bandurski pozbawiony w 1919 r. funkcji biskupa pomocniczego archidiecezji lwowskiej ob. łac. miał nadzieję na objęcie naczelnego urzędu w Ordynariacie Polowym Wojska Polskiego. Tego samego roku, abp Teodorowicz przekazał abp. Bilczewskiemu informację, jakoby sfery wojskowe niezadowolone z wyboru bp. Stanisława Galla usiłowały wprowadzić na jego miejsce zdymisjonowanego biskupa lwowskiego. Autor doniesienia był zdania, iż trzeba temu stanowczo przeszkodzić. Podczas pobytu Naczelnika Państwa J. Piłsudskiego we Lwowie, abp Bilczewski spotkał się z nim 26 VI 1919 r. poruszając m.in. 
już dosyć tego dobrego. Od rana do wieczora istne zatrzęsienie z tymi rozmaitymi ludźmi i sprawami.

Arcybiskup Kakowski strasznie jest odosobniony i od świeckich, i zwłaszcza od kleru. To smutne, bo w tych czasach bardzo potrzeba skupienia sił. Będę się musiał też zająć organizacją katolicką ${ }^{345}$. Ludzie chcą tego i czują potrzebę wielką organizacji. Szóstego lutego o 5 po obiedzie ma być u mnie zebranie w tej sprawie. Czy by kto ze Lwowa nie przyjechał? Może Zajchowski? Myśleć też muszę o różnych praktycznych stronach jak mieszkaniu, wikcie. etc., bo tu dłużej trudno jest siedzieć na głowie misjonarzom.

Ściskam Cię najserdeczniej

Twój Józef

Bądź tak dobry i doślij listy do matki mojej, a raczej do brata ${ }^{346}$. Każ bratu przyjdź po ten list, bo wewnątrz są pieniądze ${ }^{c}$.

\section{Dokument 133}

\section{Ekscelencjo! ${ }^{\mathrm{a}}$}

Niniejszym mam zaszczyt ponownie korzystać z łaskawości Waszej Ekscelencji i stosownie do postanowienia ostatniego zebrania Księży Delegatów Biskupich uprzejmie

ten temat. Relację z audiencji zamieścił w dzienniku: „Powiedziałem: «Pan Naczelnik mówił przez Ks. Arc[ybiskupa] Teodor[owicza], że Ks. Bandurskiego chce powołać na ważniejsze stanowisko w Król[estwie] Pol[skim], że Ks. B[andurskiem]u biskupi robią krzywdę nie dopuszczając do pracy w Polsce. Otóż w interesie sprawy publ[icznej], w imię prawdy muszę oświadczyć, że biskupi jeszcze w r. 1913 zwrócili uwagę Ks. Bandurskiego, że musi opuścić swoje stanow[isko] sufragana, bo dostał się w ręce szantażystów, którzy go kompromitują. Nieprawdą więc jest, jakoby biskupi byli go usunęli dla jego niemądrych występów politycznych w czasie wojny; powód główny jest natury czysto kościelnej. Naczelnik musi to wiedzieć, przykro mi o tym mówić, ale przez podsuwanie biskupom celów egoistycznych, Ks. B[andurskiem]u się nie pomoże, a w społeczeństwie utrzymuje się szkodliwy ferment, który wykorzystują nieprzyjaciele Kościoła, a nawet narodu». P[iłsudski]: «szkoda wielka, bo b[iskup] Band[urski] dobrym jest mówcą i podnosił ducha żołnierzy». Zrozumiał jednak, że wobec takich racji bronić go nie wypada”. Dwa miesiące później, 25 VIII 1919 r., ponownie doszło do spotkania obu rozmówców, tym razem w Warszawie. Także wówczas rozmawiano m.in. o bp. Bandurskim. Abp Bilczewski zwrócił uwagę Piłsudskiego na zainicjowaną przez bp. Bandurskiego przy udziale niektórych „oficerów i socjalistów” kampanię przeciwko polskim biskupom. Naczelnik wprawdzie wiedział o tym, ale mimo to opowiedział się za powierzeniem mu jakiejś posady, np. kapelana dla wojska Frontu Białoruskiego. Prosił abp. Bilczewskiego o poparcie tej idei na forum episkopatu. Ten obiecał spełnić tę prośbę, ale nie krył sceptycyzmu odnośnie do reakcji pozostałych hierarchów. Jeszcze raz podkreślił, że Bandurski nie został zwolniony z sufraganii lwowskiej z powodów politycznych, lecz „natury innej”. Jeśli nie zaprzestanie on agitacji przeciw biskupom, wówczas ci będą zmuszeni ogłosić rzeczywiste powody jego dymisji, a wtedy protektorzy Bandurskiego „będą się musieli wstydzić”. AALK, bsygn., J. Bilczewski, Dziennik, s. 782-783, 794.

345 Zob. list 124 niniejszej części.

346 Mowa o Michale Teodorowiczu.

c U dołu ręką abp. Bilczewskiego nota: „List otrzymałem 31/I [1]919 z Warsz[awy] przez porucznika Bohdana Marchwińskiego".

a Powyżej obcą ręką niebieską kredką napisano nazwisko: „Teodorowicz”. List jest powielonym maszynopisem pisanym obustronnie na pojedynczej kartce formatu zbliżonego do A4. Brak miejsca wystawienia dokumentu i datacji. 
prosić, aby w celu umożliwienia rozwinięcia działalności społeczno-katolickiej w diecezjach, zechciała łaskawie Wasza Ekscelencja wydelegować do Warszawy na dzień 25 lutego (Dom Księży, [ul.] Miodowa 13) trzech kapłanów, którzy obecnie zajmują się sprawami społecznymi w Diecezji Waszej Ekscelencji, a którzy by mogli dać nam o tej pracy sprawozdanie i odpowiednio upoważnieni powziąć należyte uchwały. Zjazd przeto, który proponuję, będzie miał za zadanie ostateczne ujęcie w swoje ręce i unormowanie akcji katolicko-społecznej w Polsce, opierając się w swej pracy na przedyskutowaniu następującego programu:

Wtorek 25/II godz. 9 rano:

1. Zagajenie.

2. Wybór prezydium.

3. Sprawozdanie z działalności katolickiej organizacji młodzieży zarobkującej.

4. Projekt pracy dalszej - ks. Jarosz ${ }^{347} \mathrm{z}$ Poznania.

5. Dyskusja.

6. Wnioski.

Godz. 3 po poł[udniu]:

1. Sprawozdanie z działalności katolickiej organizacji kobiet pracujących.

2. Projekt pracy dalszej - ks. Schulz ${ }^{348} \mathrm{z}$ Poznania.

3. Dyskusja.

4. Wnioski.

Środa 26/II godz. 9 rano:

1. Sprawozdanie z dotychczasowej akcji wśród robotników.

2. Siła socjalizmu.

3. Siła ludowców.

4. Zamiary nasze:

a) akcja kulturalno-oświatowa. ks. Dymek ${ }^{349}$ z Poznania.

b) Związki zawodowe - ks. dr Hilchen ${ }^{350}$.

347 Jarosz Ludwik (1888-1935), święcenia kapłańskie w 1912 r. w Poznaniu, w 1912 r. wikariusz w Śremie, 1912-1914 wikariusz w Lesznie Wielkopolskim, 1914-1917 wikariusz w Śmiglu, 1917-1929 duszpasterz młodzieży w Poznaniu; był sekretarzem generalnym Związku Stowarzyszeń Młodzieży Polskiej, kuratorem młodzieżowych stowarzyszeń parafialnych, 1929-1932 wykładowca socjologii w poznańskim Seminarium Duchownym, 1933-1935 proboszcz w Ostrowiu Wielkopolskim. J. Odziemkowski, Jarosz Ludwik, w: $S B K S w P$, t. 1, s. 189.

348 Postać niezidentyfikowana.

${ }^{349}$ Dymek Walenty (1888-1956), święcenia kapłańskie w 1912 r. w Gnieźnie, 1912-1916 wikariusz w Ostrzeszewie, od 1916 r. sekretarz generalny Związku Katolickich Robotników Polskich i redaktor jego organu prasowego „Robotnik”; był działaczem Związku Spółek Zarobkowych, współorganizatorem Narodowego Stronnictwa Ludowego, delegatem abp. E. Dalbora ds. społecznych, inicjatorem wielu akcji charytatywnych. W 1929 r. mianowany biskupem pomocniczym poznańskim, od 1930 r. asystent kościelny Naczelnego Instytutu Akcji Katolickiej w Poznaniu, w 1946 r. mianowany arcybiskupem poznańskim. R. Gajewski, Dymek Walenty, w: SBKSwP, t. l, s. 122-123.

${ }^{350}$ Hilchen Henryk (1881-1956), święcenia kapłańskie w 1912 r. w Warszawie, dr nauk politycznych i ekonomicznych, od 1915 r. sekretarz generalny Stowarzyszenia Robotników Chrześcijańskich w Warszawie, redaktor „Przewodnika Społecznego”, 1919-1920 dyrektor Zjednoczenia Stowarzyszeń Robotników Chrześcijańskich, od 1922 r. doradca nuncjatury apostolskiej w Warszawie, 1931-1945 proboszcz parafii 
Środa 26/II godz. 3 po poł[udniu]:

1. Podstawy organizacji robotniczej w Polsce.

2. Dyskusja.

3. Przyjęcie ustawy normalnej - ks. Dymek z Poznania.

Czwartek 27/II godz. 9 rano:

1. Sprawa sekretariatów - ks. Adamski Wal[erian $]^{351}$ z Poznania.

2. Komisje społeczne.

3. Dyskusja.

4. Wnioski.

5. Prasa społeczno-katolicka.

Dowiaduję się, że p. p. hr. Łubieński ${ }^{352}$ i Leszek Wiśniowski ${ }^{353}$ rozesłali do konsystorzy zaproszenia opatrzone moim podpisem i powołujące się na mój protektorat. Oświadczam tedy, że nic z tym nie mam wspólnego; natomiast dla uchylenia w przyszłości podobnych samowolnych wystąpień, po porozumieniu się z Najp[rzewielebniejszymi] Księżmi Arcypasterzami Dalborem i Kakowskim zgodziłem się na utworzenie pewnego rodzaju biura pod mym patronatem (Miodowa 14) dla roboty katolickiej, które w niczym nie przesądza ani organizacji politycznej, ani w ogóle organizacji katolickiej.

$\mathrm{Z}$ najgłębszą czcią

† J[ózef] Teodorowicz

\section{Dokument 134}

Kochany Księże Arcybiskupie! ${ }^{a}$

Przyjedź, proszę, na konferencję w naszych sprawach 26. Sprawy bardzo ważne, a do tego czasu rozejm będzie ${ }^{354}$. Nie pieść się nadto ze sercem, tylko przyjeżdżaj. Po tych

pw. Matki Bożej Częstochowskiej w Warszawie, 1945-1947 proboszcz w Międzyrzeczu Wlkp., od 1947 r, proboszcz parafii pw. św. Ottona w Słupsku. B. Micewski, Hilchen Henryk, w: SBKSwP, t. 1, s. 172-173.

${ }^{351}$ Adamski Walerian (1885-1965), święcenia kapłańskie w 1911 r. w Poznaniu, dr filozofii, od początku pracy duszpasterskiej zajmował się młodzieżą; był sekretarzem generalnym Związku Towarzystw Młodzieży w archidiec. gnieźnieńskiej i poznańskiej, redaktorem naczelnym „Przyjaciela Młodzieży”, 1919-1934 dyrektor Zjednoczenia Młodzieży Polskiej na teren Polski, 1924-1927 wykładowca socjologii w poznańskim Seminarium Duchownym, współzałożyciel Katolickiej Szkoły Społecznej w Poznaniu, prezes Drukarni i Księgami św. Wojciecha. W czasie II wojny światowej przebywał w obozach koncentracyjnych, od $1947 \mathrm{r}$. pracował znowu w Poznaniu. J. Wycisło, Adamski Walerian, w: SBKSwP, t. 1, s. 3-4.

${ }^{352}$ Łubieński Roger (1849-1930), polski działacz katolicki, historyk i publicysta, 1883-1888 poseł do Sejmu Krajowego we Lwowie, 1906-1909 założyciel i redaktor warszawskiego tygodnika katolickiego „Wiara”, w 1907 r. należał do grona założycieli Związku Katolickiego dla regionu Królestwa Polskiego i Sodalicji Mariańskiej dla mężczyzn, był autorem artykułów w prasie katolickiej i opracowań historycznych. L. Kula, Eubieński Roger, w: SBKSwP, t. 2, red. zbior., Warszawa 1994, s. 102.

${ }^{353}$ Postać niezidentyfikowana.

a Powyżej obcą ręką ołówkiem błędnie napisano nazwisko: „Puzyna”. List pisany jest na podwójnej, nieliniowanej kartce formatu zeszytowego. Papier nie posiada znaku wodnego. Brak miejsca wystawienia dokumentu.

${ }^{354}$ Nawiązanie do nadziei na zawieszenie broni w walkach polsko-ukraińskich na terenie Małopolski Wschodniej. 
katuszach, które tam przechodziłeś, będzie to nawet wypoczynek. Wobec tego, że liczę na Twój przyjazd nie piszę więcej. Sprawę zwołania delegatów ${ }^{355}$, o której pisałem do Ciebie, wobec konferencji biskupiej odkładam na później.

Ściskam Cię serdecznie

Wtorek, 18/I [1]919

Twój Józef

\section{Dokument 135}

\section{Ekscelencjo $^{\mathrm{a}}$}

Wyłaniają się dzisiaj w klubach sejmowych sprawy, które, będąc ściśle związane z interesami Kościoła, domagają się ustalenia, wyjaśnienia i odpowiednich decyzji

Nie mogę zawsze brać na własną odpowiedzialność stanowiska, jakie zająć należy i dlatego czuję potrzebę zwrócić się do Najdostojniejszych Arcypasterzy z prośbą, by we spólnej ${ }^{b}$ naradzie zająć się raczyli roztrząśnieniem ${ }^{c}$ kwestii, o których w części nadmieniłem już w mym poprzednim piśmie.

Porozumiałem się już w tej mierze z Najdostojniejszym Księdzem Arcypasterzem Warszawskim ${ }^{356}$, który naznacza termin zjazdu na dzień 12 i 13 marca i zaprosi Waszą Ekscelencję na naradę do swojego pałacu.

Zawiadamiając o tym Waszą Ekscelencję i prosząc gorąco o przybycie, łączę wyrazy prawdziwej czci i szacunku.

Warszawa, 4 marca $1919 \mathrm{r}$.

† Józef Teodorowicz

J[ego] E[kscelencja] Ks. Józef Bilczewski

Arcybiskup Lwowski

we Lwowie

\section{Dokument 136}

Kochany Księże Arcybiskupie! ${ }^{a}$

Bardzo Ci dziękuję za twój list, myślałem, że Cię najdę we Lwowie, ale było już za późno. Twoje zlecenie do Rattiego i obecne załatwiłem. Ratti się zgadza na wszystko

355 Por. list 133 niniejszej części.

a Powyżej obcą ręką niebieską kredką napisano nazwisko: „Teodorowicz”. List jest powielonym maszynopisem. Został sporządzony na pojedynczej kartce formatu zbliżonego do A4. Papier nie posiada znaku wodnego.

b Zapis zgodny z oryginałem; poprawnie powinno być: wspólnej.

c Zapis zgodny z oryginałem; tu w znaczeniu: rozważeniem, rozstrzygnięciem.

${ }^{356}$ Był nim wówczas abp Aleksander Kakowski.

a List pisany jest na podwójnej, nieliniowanej kartce formatu zeszytowego. Brak znaku wodnego. 
w sprawach, które poruszyłeś, ale to już dawniejsza historia, zaś co do seminarium ${ }^{357}$, to Sapieha ruszył tę kwestię w ministerium dla swego seminarium, co tym samym przesądzi i Twoją sprawę.

Nie wiem czy wiesz, że jest w sejmie interpelacja wniesiona w sprawie Bandurskiego, jest też w „Naprzodzie” wydrukowany Twój list po inwazji pisany do niego: wszystko robota Piłsudskiego, który tego dla bardzo osobistych celów potrzebuje. Telefonował mi właśnie Sapieha, że jedziesz do Poznania ${ }^{358}$. Jest to konieczne, bo narady konferencji w sprawie agrarnej zwłaszcza są niesłychanej dla nas wagi.

Jak Ci kuracja zrobiła? Boję się, że miałeś nadto słotny czas, który się nie bardzo nadawał zwłaszcza w Truskawcu ${ }^{359}$ na kurację. Mnie tu Krynica bardzo dobrze zrobiła. Zabawię tu jeszcze tydzień, stąd jadę do Krakowa, a stamtąd do Poznania gdzie się też obaczymy.

Ściskam Cię serdecznie

Krynica, d[nia] 13/VIII [1]919

Twój Józef

Sapieha bawi w Nawojowej ${ }^{360}$.

\section{Dokument 137}

\section{Carissime $^{\text {Ia }^{2}}$}

Konferencja zajęła się sprawą B[andurskiego]. Ze sprawozdań pewnych wnosiliśmy na to, że Rzym nie chce brać za nią odpowiedzialności i od wszelkiego stanowczego kroku się uchyli. To jest zresztą zupełnie zrozumiałe, a obecne stanowisko Rattiego potwierdziło nas w tym przekonaniu. Wszelkie więc kombinowanie, że Rzym nie dozwoli biskupom pokierować samodzielnie tą kwestią, albo że sam inicjatywę podejmie, są pozbawione wszelakiej podstawy. Ostatecznie stanęło na tym, że mnie upoważniono bym mówił z Tobą i z nim. Mam Ciebie o to prosić, byś mu dał probostwo w Stanisławowie ${ }^{361}$

357 Rzecz dotyczy dotacji ze strony Ministerstwa Wyznań Religijnych i Oświecenia Publicznego dla Seminarium Duchownego ob. łac. we Lwowie.

358 Abp Bilczewski przybył 26 VIII 1919 r. do Poznania witany przez prymasa abp. E. Dalbora, duchowieństwo i wojsko. Po zwiedzeniu kościoła farnego i zamku, gość udał się po południu do Gniezna na pierwszą wspólną konferencję Episkopatu Polskiego 26-30 sierpnia w niepodległej Ojczyźnie. Metropolita lwowski podczas uroczystej Mszy św. 26 sierpnia inaugurującej zjazd biskupów, a celebrowanej u grobu św. Wojciecha wygłosił kazanie. AALK, bsygn., J. Bilczewski, Dziennik, s. 795-796; tenże, Kazanie wypowiedziane z okazji zjazdu biskupów w katedrze gnieźnieńskiej u grobu św. Wojciecha w dniu 26 sierpnia 1919 r., w: tenże, Listy pasterskie, odezwy, kazania i mowy okolicznościowe, t. 3, Lwów 1924, s. 465-473.

359 Abp. Bilczewski przebywał na kuracji w Truskawcu (Małopolska Wschodnia) w dniach 12 VII 9 VIII $1919 \mathrm{r}$.

${ }^{360}$ Nawojowa - miejscowość koło Nowego Sącza; majątek hr. Edwarda Stadnickiego i jego żony Heleny Marii z Sapiehów, siostry krakowskiego bp. Adama Stefana Sapiehy.

a List pisany na 2 stronicach czystego papieru formatu zeszytowego. W lewym górnym rogu obcą ręką niebieską kredką napisano: „Teodorowicz”.

${ }^{361}$ Stanisławów - miasto wojewódzkie w Małopolsce Wschodniej na terenie archidiec. lwowskiej ob. łac.; funkcjonowała tam jedna z bardziej prestiżowych parafii rzymskokatolickich. 
(Biskup Pelczar mówił też o Trembowli ${ }^{362}$, ale ta obsadzona). Tak biskup Pelczar, jak $\mathrm{i}$ inni biskupi byli tego zdania, że jest koniecznym szybkie załatwienie sprawy z B[andurskim]. Bliżej opowiem Ci ustnie. Później biskup miński ${ }^{363}$ okazał gotowość tymczasowo wziąć go do siebie. Ratti zgodził się na to natychmiast i ja napisałem do B[andurskiego], ażeby tu przyjechał w tym celu. Pytałem komitetu, czy wobec tego mam Ciebie jeszcze prosić o Stanisławów? Odrzekli, że tak, gdyż Stanisławów będzie dla niego podstawą stałą, na której może się opierać, tamto zaś jest tymczasowym tylko i przejściowym załatwieniem. O Stanisławowie wspomniałem naturalnie ja wzmiankując rozmowę z Tobą we Lwowie. Będę niezadługo we Lwowie i wtedy pogadamy bliżej.

Tymczasem łączę dla Ciebie najserdeczniejsze wyrazy i pozdrowienia

Warszawa, d[nia] 1/XI [1]919

Teodorowicz

\section{Dokument 138}

Nie ${ }^{a}$ mogłem dla zajęć wczoraj Ci służyć, dlatego przyjm tą drogą życzenia noworoczne wszystkiego najlepszego.

Oddany $\mathrm{Ci}$.

$1 / \mathrm{I}[1] 920$

\section{Dokument 139}

\section{Carissime! $^{\mathrm{a}}$}

Dopiero otrzymałem Twój projekt i jeszcze w czas oddam go Dalborowi. W zasadzie przyjęliśmy tę zasadę kombinując progresywne pensje z ziemią ${ }^{364}$. Projekt opracuje Sze-

${ }^{362}$ Trembowla - miasto powiatowe w woj. Tarnopol (Małopolska Wschodnia) na terenie archidiec. lwowskiej ob. łac., z parafią rzymskokatolicką.

${ }^{363}$ Bp Zygmunt Łoziński (1870-1932), ostatni rządca reaktywowanej diecezji mińskiej (1917-1925). Po aresztowaniu 1 VIII i powtórnie 4 IX $1920 \mathrm{r}$. przez władze sowieckie został osadzony w więzieniu, a po roku zwolniony wskutek interwencji rządu polskiego; wyjechał wówczas do Polski. Dnia 2 XII 1925 r. mianowany pierwszym biskupem diecezji pińskiej. B. Czaplickij, I. Osipova, Kniga pamiati. Martirolog katoliczeskoj Cerkwy w SSSR, Moskwa 2000, s. 358-359.

a List pisany na karcie wizytowej z nadrukiem: „Arcybiskup Teodorowicz”. Brak tytulatury, autografu autora i miejsca wystawienia dokumentu.

a Powyżej obcą ręką niebieską kredką napisano nazwisko: „Teodorowicz” oraz ołówkiem liczbę „15”. List pisany jest na podwójnej, nieliniowanej kartce formatu zeszytowego. Brak znaku wodnego.

${ }^{364}$ Jednym z głównych przedmiotów rozmów pomiędzy polskim rządem a episkopatem po roku 1918 były sprawy majątkowe Kościoła. Podczas zjazdu episkopatu w Gnieźnie 26-30 VIII 1919 r. abp Bilczewski stwierdził: „Jeżeli dobro Kościoła będzie tego wymagało, to biskupi Małopolski gotowi są zrzec się ziemi aż do ostatniej morgi, przedstawili jednak program zatrzymania pewnych obszarów, aby zabezpieczyć duchowieństwo przed rządem, który dzisiaj może dać, a jutro odebrać pensję". Dnia 10 VII 1919 r. Sejm uchwalił ustawę o parcelacji i osadnictwie. Dało to asumpt do rozpoczęcia nieoficjalnych rozmów na ten temat na linii rząd - nuncjusz apostolski - episkopat. W połowie 1921 r. rząd zwrócił się do Stolicy Apostolskiej 
lążek ${ }^{365}$ wedle naszych uchwał i w czerwcu (zdaje mi się 6) zejdzie się komitet ${ }^{366}$ znowu. Ciebie powołujemy do komitetu raz dla Twej osoby, a potem dla marki prawowierności wobec Rattiego, który uznaje komitet arcybiskupów i krakowskiego biskupa. W sprawie dodatków dla księży będę jutro z Sapiehą u Grabskiego. Obrady nasze były bardzo intensywne i bardzośmy radzi z ich przebiegu. W sprawie Bandurskiego Dalbor pisze do Rzymu o inspektorat w armii dla niego ${ }^{367}$. Godzi się na to kardynał warszawski ${ }^{368} \mathrm{i}$ Gall. Na razie tyle. W sprawie Gennocciego ${ }^{369}$ napiszę $\mathrm{Ci}$.

Ściskam Cię serdecznie

† Teodorowicz

Warszawa, 15/IV [1]920

Bardzo rad jestem, ze się udało ruszyć sprawę planu nauczania religii w szkołach i Ciebie prosimy o referat, z czym się zwróci do Ciebie Dalbor. Jest to uratowanie sytuacji. Co do ewentualnego udziału Ukraińców w związku katechetów, to też dobrze postanowiono. Wałęga napisze list do kleru, a Ty będziesz jednym z tych, którego poproszą o myśli pewne do tego listu.

\section{Dokument 140}

Mój Drogi! ${ }^{a}$

[ul.] Miodowa 6, 2 piętro

Proszę Cię ze Sapiehą dzisiaj na [godz.] 8 wieczór na siekanego zająca. Dzisiaj na konferencji ${ }^{370}$ nie będę, bo mi nie pozostaje nic jak tylko wycofać się zupełnie po dzisiejszym

z prośbą o rozpoczęcie rozmów na temat dóbr poduchownych i ziemi w posiadaniu Kościoła. Dnia $23 \mathrm{~V}$ 1921 r. powołano Komisję Papieską w składzie: bp Henryk Przeździecki, bp Stanisław Łukomski i bp Adolf Szelążek, która zajęła się tą problematyką. S. Wilk, Episkopat Kościoła katolickiego w Polsce w lalach 19181939, Warszawa 1992, s. 115-116.

365 Szelążek Adolf (1865-1950), święcenia kapłańskie w 1888 r. w Płocku, był wykładowcą Seminarium Duchownego w Płocku i Petersburgu, rektorem seminarium płockiego, 1918-1925 biskup pomocniczy płocki, od 1925 r. biskup diecezjalny w Lucku. Podczas II wojny światowej aresztowany przez Sowietów i więziony w Kijowie, po czym w 1946 r. deportowany do Polski; osiadł wówczas w Bierzgłowie k. Torunia. P. Nitecki, Biskupi, s. 200.

${ }^{366}$ Komitet Biskupów funkcjonujący w łonie Episkopatu Polskiego składał się z czterech arcybiskupów: Józefa Bilczewskiego (Lwów - obrz. łacińskiego), Edmunda Dalbora (Gniezno - Poznań), Aleksandra Kakowskiego (Warszawa) i Józefa Teodorowicza (Lwów - obrz. ormiańskokatolickiego). S. Wilk, Episkopat Kościoła, s. 61.

${ }^{367}$ W 1920 r. bp W. Bandurski został mianowany kapelanem generalnym sił zbrojnych Litwy Środkowej.

368 Tj. kard. A. Kakowski.

369 Właściwie: Genocchi Giovanni (1860-1926), święcenia kapłańskie w 1883 r. w Rawennie, misjonarz Najświętszego Serca Jezusa, wykładowca historii w miejscowym Seminarium Duchownym; pracował też w Syrii, Turcji, Nowej Gwinei i Kolumbii. Papież Benedykt XV mianował go wizytatorem apostolskim Ukrainy. J. Bazydło, Genocchi Giovanni, w: EK, t. 5, red. zbior., Lublin 1989, kol. 966-967.

a Powyżej obcą ręką błędnie napisano nazwisko: „Puzyna”. List pisany jest na podwójnej, nieliniowanej kartce formatu kieszonkowego. Brak miejsca wystawienia dokumentu i datacji.

${ }^{370}$ Konferencja episkopatu odbyła się w dniach 29-30 XII 1920 r. w Warszawie. AALK, bsygn., J. Bilczewski, Dziennik, s. 823-824. 
wykluczeniu mnie z liczby arcybiskupów i to tak publicznym, i tak kompromitującym, i demonstracyjnym. Więc do miłego obaczenia się

Józef

\section{Dokument 141}

Krynica, d[nia] 29/VIII 1920

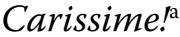

Myślałem, że po Krynicy będę się z Tobą widział we Lwowie, dokąd się chciałem udać dla wyświęcenia Bohdanowicza ${ }^{371}$. Niestety, sprawy polityczne powołują mnie do Warszawy i dlatego pisemnie przedkładam Ci moją sprawę. Idzie mi o księdza Isakowicza ${ }^{372}$, którego przez rok miałem w Warszawie, a teraz chciałbym go dać do Lwowa. Otóż jeślibyś miał jaką szkołę wolną, to bym Cię prosił o nadanie jej jemu. Zaręczyć Ci za niego pod każdym względem jak za wzorowego kapłana i nadzwyczaj sumiennego katechetę [mogę]. W Warszawie aż się sam zamęczył katecheturą z uszczerbkiem swego zdrowia, a zyskał sobie powszechną miłość i szacunek tak nauczycieli, jak uczniów. Adres jego obecny: Jarosław u nadradcy Teofila Isakowicza.

Myślałem sobie nieraz, jak ciężkie musiałeś przechodzić chwile we Lwowie. Dzięki Bogu istnym cudem uratowani jesteśmy ${ }^{373}$. Myśleliśmy z Sapiehą, który bawi w tych stronach, że byłoby dobrze po ostatnim liście wzywającym społeczeństwo do mo-

b Zapis zgodny z oryginałem; poprawnie powinno być: zobaczenia.

a List pisany jest na pojedynczej, nieliniowanej kartce formatu zbliżonego do A4. W nagłówku kartki nadruk: „Sejm Ustawodawczy Rzeczypospolitej Polskiej”.

371 Właściwie: Bogdanowicz Adam (1898-1941), święcenia kapłańskie w 1920 r. we Lwowie w obrz. ormiańskokatolickim, 1920-1928 katecheta lwowskich szkół średnich, 1928-1935 administrator parafii w Horodence, od 1932 r. obrońca węzła małżeńskiego w Sądzie Biskupim i kanonik gremialny Kapituły Katedralnej we Lwowie. Podczas II wojny światowej współpracował ze Związkiem Walki Zbrojnej obszaru lwowskiego; 2 IV 1940 r. aresztowany przez NKWD i osadzony w więzieniu lwowskim, 19 XI 1941 r. skazany na śmierć podczas procesu 14 przywódców ZWZ. Istnieją trzy wersje jego śmierci: 24 II 1941 r. rozstrzelany we Lwowie wraz z pozostałymi skazańcami; 25 VI t.r. miał zginąć podczas wycofywania się NKWD z więzienia „Brygidek” we Lwowie; trzecia wersja sugeruje śmierć w kijowskim więzieniu. Znany był jako znakomity duszpasterz, katecheta i kaznodzieja. T. Za1eski, Stownik, s. 37-38; J. Wołczański, Kaptani męczennicy - świadkowie wiary Kościoła Lwowskiego. Ksiadz Adam Henryk Bogdanowicz (1898-1941), RW (Lwów), 7 (1999), nr 2, s. 17.

372 Właściwie: Issakowicz Leon (1897-1944), święcenia kapłańskie w 1919 r. w Warszawie w obrz. ormiańskokatolickim, 1919-1920 katecheta w Warszawie, w 1920 r. mianowany wikariuszem katedralnym we Lwowie, 1920-1922 asystent przy Katedrze Historii Sztuki Kościelnej Wydziału Teologicznego Uniwersytetu Jana Kazimierza we Lwowie, od 1922 r. katecheta w Gimnazjum ss. Urszulanek tamże, od 1933 r. notariusz Kurii Biskupiej, od 1930 r. kanonik gremialny Kapituły Katedralnej, w 1938 r. odznaczony godnością prałata papieskiego, 1936-1944 proboszcz w Stanisławowie; doprowadził do koronacji 2 I 1939 r. słynącego łaskami obrazu Matki Bożej Łaskawej tamże. T. Zaleski, Słownik, s. 53.

${ }^{373}$ Nawiązanie do inwazji bolszewickiej na Polskę w 1920 r. 
dlitwy błagalnej, teraz je wezwać do modłów dziękczynnych. Ułożyliśmy nawet taką odezwę, którą on prześle Dalborowi i Kakowskiemu ${ }^{374}$. W Warszawie jest niedobrze pod względem politycznym. Polecam się Twej pamięci i modłom.

Oddany $\mathrm{Ci}$

† Teodorowicz

\section{Dokument 142}

\section{Carissime?}

Dziękuję Ci za Twój list i łaskawą Twą gotowość w sprawie Isakowicza. Wystarczy mu zupełnie katechetura szkół wydziałowych.

Wyobrażam sobie, co się tam dziać musi u Ciebie, skoro te biedy i jęki wszystkie tak bezpośrednio obijają się o Ciebie. Modlę się, by Cię Bóg na siłach potrzymał.

Kardynał Mercier ${ }^{375}$ wydał śliczny list wraz z całym episkopatem belgijskim z okazji naszego listu wystosowanego do nich ${ }^{376}$. Jest w tym pewna racja, że zwycięstwo nie jest jeszcze ostateczne, z drugiej jednak strony motyw psychologiczny i duchowny wywołany obroną Warszawy i Polski niewyzyskany minie bezpowrotnie. Każdy inny już będzie nieporównanie słabszy. Ale może ostatecznie na tym się skończy, że listu obecnie nie wydamy, choć Wałęga wcale myśl listu obecnie aprobuje. Napiszę

${ }^{374}$ Pod koniec sierpnia 1920 r. abp Teodorowicz wspólnie z bp. Sapiehą opracowali odezwę do duchowieństwa i wiernych zachęcając, aby 8 września t. r. we wszystkich kościołach urządzono nabożeństwa dziękczynne za obronę Warszawy. Ale zarówno prymas kard. Dalbor, jak i kard. A. Kakowski odmówili tej inicjatywie poparcia twierdząc, że publikacja odezwy może wciągnąć Kościół w rozgrywki polityczne, wymierzone przeciwko Piłsudskiemu. S. Wilk, Episkopat Kościoła, s. 340-341.

a List pisany jest na podwójnej, nieliniowanej kartce formatu zeszytowego. Brak znaku wodnego.

${ }^{375}$ Mercier Désiré (1851-1926), święcenia kapłańskie w 1874 r. w Belgii, 1877-1882 wykładowca filozofii w Seminarium Duchownym w Mecheln, od 1882 r. pierwszy kierownik Katedry Filozofii Tomistycznej erygowanej na życzenia papieża Leona XIII na Uniwersytecie Katolickim w Lowanium, od 1889 r. pierwszy przewodniczący Institut Supérieur de Philosophie tejże uczelni, założyciel w 1894 r. periodyku „Revue néoscolastique"; w 1906 mianowany arcybiskupem i prymasem Belgii. L. Oening-Hanhoff, Mercier Désiré, w: $L T h K$, Bd. 7, herausg. von J. Höfer, K. Rahner, Freiburg 1986, kol. 306.

${ }^{376}$ Kard. Mercier cieszył się opinią wielkiego przyjaciela Polski. Okazywał niezwykłą życzliwość polskim studentom w Lowanium, a już szczególne zainteresowanie przejawiał względem losów odrodzonego państwa polskiego. Do tej sympatii odwołał się abp Bilczewski, przesyłając mu 2 II $1919 \mathrm{r}$. za pośrednictwem abp. Teodorowicza memoriał w sprawie Galicji Wschodniej i Śląska. Kolejne pismo w tej sprawie metropolita lwowski wysłał doń 16 lutego t.r. Kiedy natomiast w 1920 r. zagrażał Polsce najazd Armii Czerwonej, belgijski prymas zarządził wraz z episkopatem publiczne modły w intencji zażegnania niebezpieczeństwa oraz zorganizował składkę na rzecz polskich sierot wojennych. K. Wais, Śp. Kardynat Mercier. Wspomnienie pośmiertne, Lwów 1926, s. 15; AALK, bsygn., J. Bilczewski, Dziennik, s. 717, 723, 731. 
Ci jeszcze o jednej sprawie, ale dopiero gdy się ostatecznie uda. Jutro idę do Piekarskiego $^{377}$ i Dembińskiego ${ }^{378}$.

Ściskam Cię serdecznie. Najoddańszy

† Teodorowicz

Warszawa, 1/IX [1]920

\section{Dokument 143}

\section{Carissime $^{\text {Ia }^{2}}$}

Dziękuję Ci serdecznie za przysłany mi list Twój ${ }^{379}$, którego Ci szczerze gratuluję. Poruszasz w nim najaktualniejsze problemy z plastyką, taktem i właściwą Tobie bezpośredniością, a przy tym popularnością. Będę się starał podać go do „Rzeczpospolitej”380. Spieszę się, bo jutro prawdopodobnie będę miał mowę w senacie. Sprawa z senatem jednak źle się zapowiada. Ściskam Cię serdecznie i pozdrawiam do obaczenia, da Bóg, na W[szystkich] Świętych.

Oddany Ci zawsze

Warszawa, d[nia] 12/X [1]920

Józef

377 Piekarski Stanisław (1868-1943), dr praw, urzędnik Namiestnictwa we Lwowie, 1901-1918 pracownik Ministerstwa Wyznań i Oświaty w Wiedniu, od 1918 r. urzędnik Ministerstwa Wyznań Religijnych i Oświecenia Publicznego w Warszawie; początkowo naczelnik wydziału departamentu (1918-1921), potem dyrektor departamentu wyznań (1921-1926). Z jego inicjatywy odbywały się konferencje międzyministerialne w sprawie konkordatu Polski ze Stolicą Apostolską, Zmarł w Krakowie. S. Konarski, Piekarski Stanisław, w: $P S B$, t. 26, red. zbior., Wrocław 1981, s. 74-75.

${ }^{378}$ Dembiński Bronisław (1858-1939) dr filozofii, habilitację uzyskał w 1886 r. z historii powszechnej na UJ, 1891-1918 prof. na Uniwersytecie Lwowskim, 1914-1918 poseł do parlamentu austriackiego, 1918-1919 prof. na Uniwersytecie Warszawskim, 1919-1922 urzędnik Ministerstwa WRiOP, od 1923 r. prof. na Uniwersytecie Poznańskim. C. Brzoza, Dembiński Bronistaw, w: Kto byt kim, s. 36.

a Powyżej obcą ręką niebieską kredką napisano nazwisko: „Teodorowicz” oraz ołówkiem liczbę „12”. List pisany jest na podwójnej, nieliniowanej kartce formatu zeszytowego. Brak znaku wodnego.

379 J. Bilczewski, Poktosie z czasu wojny bolszewickiej. List pasterski do duchowieństwa $i$ wiernych. Lwów 24 IX 1920 r., w: tenże, Listy pasterskie, t. 3, s. 266-279.

380 „Rzeczpospolita” - dziennik założony w 1920 r. w Warszawie, red. naczelny - Stanisław Stroński. Pismo związane było z Narodowo-Chrześcijańskim Stronnictwem Ludowym; 60\% akcji posiadał Ignacy Paderewski, pozostałą część członkowie stronnictwa. Sekretarzem redakcji został Stanisław Strzelecki, dział wojskowy podlegał gen. Józefowi Dowbor-Muśnickiemu, teatralny i literacki - Kornelowi Makuszyńskiemu, muzyczny - Stanisławowi Niewiadomskiemu, gospodarczy - Edwardowi Rose. Pismo ukazywało się w dwóch wydaniach warszawskich: porannym i wieczornym; edycje prowincjonalne miało w Poznaniu, Krakowie, Lwowie i Wilnie. W 1924 r. pismo zakupił Wojciech Korfanty, ale redakcję opuściło większość pracowników na czele ze S. Strońskim. Periodyk stał się organem Chrześcijańskiej Demokracji. W 1928 r. redakcję objął ks. Zygmunt Kaczyński, a w marcu 1930 r. pismo przeszło na własność spółki „Dom Prasy Katolickiej”. Połączono je zarazem z dziennikiem „Polak-Katolik”; łącznie dzienniki te drukowały 15000 egz. A. Paczkowski, Prasa polska w latach 1918-1939, Warszawa 1980, passim. 


\section{Dokument 144}

Warszawa, d[nia] 24/X 1920

\section{Carissime! ${ }^{\mathrm{a}}$}

Dawno już oddałem broszurę Dąbrowskiemu i upominałem się, o co pytałeś. Obiecał, muszę pourgowaćs81. Co do seminariów, to mówiłem z Grabskim. Okazuje wszelaką gotowość pomożeniab, a winę całą składa na Szelążka. Mam na to dowody, że Grabski mówi nieszczerze. Szelążek zrobił co mógł, a Grabski odrzucał wszelkie projekty ${ }^{382}$. Ale dobrze. Wziąłem Grabskiego za słowo i teraz mogę się upominać o jego dotrzymanie. Razem tu idę z Piekarskim.

Do miłego obaczenia się we Lwowie. Ślę Ci najserdeczniejsze pozdrowienia, dziękuję osobno za przesłanie mi listu, o którym Ci uwagi moje napisałem.

Twój

Józef Teodorowicz

\section{Dokument 145}

Kochany Księże Arcybiskupie! ${ }^{a}$

Miałbym ogromnie wiele Ci pisać, ale niestety kurier spieszy i dziś wyjeżdża, więc dlatego in medias res ${ }^{383}$ wchodzę. Loret ${ }^{384}$ przetłumaczył na włoskie broszurkę Tarnawskiego ${ }^{385}$, prosi jednak niezwłocznie by mu autor przysłał pełne nazwiska, gdyż począt-

a Powyżej obcą ręką niebieską kredką napisano nazwisko: „Teodorowicz”. List pisany jest na pojedynczej, nieliniowanej kartce formatu zeszytowego z nadrukiem: „Sejm Ustawodawczy Rzeczypospolitej Polskiej".

381 Z łac.: ponaglić.

b Zapis zgodny z oryginałem; poprawnie powinno być: pomocy.

382 Prawdopodobnie chodzi o dotacje na rzecz utrzymania Seminarium Duchownego ob. łac. we Lwowie.

a Powyżej ręką abp. Bilczewskiego napis: „Rzym, styczeń 1921”. List pisany jest na podwójnej, nieliniowanej kartce formatu zeszytowego. Znak wodny przedstawia napis: „Original Insumbria Mill C.E.M.” Brak miejsca wystawienia dokumentu i datacji.

383 Łac. w sedno rzeczy.

${ }^{384}$ Loret Maciej (1880-1949), dr filozofii, 1904-1909 nauczyciel w szkołach średnich we Lwowie i Krakowie, od 1911 r. kierował w Rzymie polską agencją prasową założoną przez Radę Narodową w Galicji dla propagowania sprawy polskiej na Zachodzie Europy. Był wydawcą pisma „Agenzia Polacca di Stampa”; na gruncie włoskim związał się z masonerią, będąc współzałożycielem w 1906 r. loży „Polonia”, 1919-1926 radca poselstwa polskiego przy Stolicy Apostolskiej, 1920-1926 radca tegoż przy Kwirynale. W 1926 r. zwolniony ze służby dyplomatycznej pozostał w Rzymie; powrócił do tej pracy w l. 1939-1946 jako minister pełnomocny przy Watykanie, a w 1. 1944-1945 przy Kwirynale. Był autorem wielu publikacji historycznych poświęconych polityczno-kulturalnym związkom Rzymu z Polską oraz nowożytnej sztuce włoskiej. A. Szklarska-Lohmannowa, Loret Sydon Maciej, w: PSB, t. 17, red. zbior., Wrocław 1972, s. 557-559.

385 Tarnawski Mieczysław (1886-1928), święcenia kapłańskie w 1910 r. we Lwowie, dr teologii, habilitacja w 1913 r. na Uniwersytecie Lwowskim, 1913-1919 prefekt studiów w lwowskim Seminarium Duchownym, 1913/14-1916/17 zastępca prof. historii Kościoła na Wydziale Teologicznym Uniwersytetu Lwowskiego, w 1916 r. prof. nadzwyczajny, w 1919 r. prof. zwyczajny, w roku akad. 1922/23 dziekan, w 1923/24 prodziekan fakultetu. Był współzałożycielem Polskiego Towarzystwa Teologicznego we Lwowie i autorem 
kowe litery nie mają żadnej siły dowodowej ${ }^{386}$. Tak samo przyślij przez poselstwo tę drugą pracę. Tu Bon ${ }^{387}$ wydał całą książkę po francusku o ucisku ukraińców ${ }^{\mathrm{b}}$ przez polaków ${ }^{\mathrm{c}} \mathrm{i}$ ona kursuje po całym Rzymie. O naszej tu rolii ${ }^{388}$ wiesz zapewne z gazet, obszernie

prac m.in. poświęconych dziejom najnowszym Cerkwi greckokatolickiej w Galicji. Za udział w wojnie 1920 r. otrzymał order Virtuti Militari. L. Grzebień, Tarnawski Mieczysław, w: SPTK, t. 7, red. L. Grzebień, Warszawa 1983, s. 306-307; J. Wołczański, Wydział Teologiczny Uniwersytetu Jana Kazimierza we Lwowie 1918-1939, Kraków 2002, passim.

${ }^{386} \mathrm{Na}$ prośbę abp. Bilczewskiego, M. Loret przełożył na j. włoski książkę ks. M. Tarnawskiego: Cerkiew unicka we Wschodniej Małopolsce w czasie inwazji rosyjskiej (1914-1917). Fakty i refleksje (Lwów 1920). Praca ta miała przeciwdziałać antypolskiej propagandzie kolportowanej przez Ukraińców w Europie Zachodniej, metodą obnażania ich rzeczywistej taktyki stosowanej wobec państwa polskiego i Kościoła katolickiego.

387 Właściwie: Bonne Frans-Xaveer (1882-1941), belgijski duchowny ze Zgromadzenia oo. Redemptorystów, święcenia kapłańskie w 1918 r., misjonarz i rekolekcjonista w klasztorze Tournai, w 2 dekadzie XX stulecia zatrudniony przez abp. A. Szeptyckiego w archidiec. lwowskiej ob. greckokatolickiego. Podczas wojny ukraińsko-polskiej 1918-1919 pełnił funkcję kapelana armii ukraińskiej. W czasie wizyt zachodnioeuropejskich misji mediacyjnych we Lwowie 1918-1919 pełnił funkcję tłumacza, 1919-1920 pracownik misji Ukraińskiej Ludowej Republiki przy Stolicy Apostolskiej, Zdecydowany wróg Polaków oraz idei związku Galicji Wschodniej z Rzeczpospolitą. Dn. 4 III 1921 r. opuścił szeregi Zgromadzenia, pełniąc funkcje duszpasterza w diasporze ukraińskiej w USA. Kościót rzymskokatolicki i Polacy, t. 1, s. 403; AALK, bsygn., J. Bilczewski, Dziennik, s. 729; Źródło: Bonne Franz Xavier - Encyclopedia of Ukraine www.encyclopediaofukraine.com/ display.asp?...pages\%5CB\%5C. Dostęp: 1 X 2017 r.

b Zapis zgodny z oryginałem; poprawnie powinno być: Ukraińców.

c Zapis zgodny z oryginałem; poprawnie powinno być: Polaków.

388 Była to misja abp. Teodorowicza i bp. Sapiehy, wysłana na prośbę rządu polskiego i zlecenie episkopatu, która przybyła do Rzymu 17 XII 1920 r., aby zreferować papieżowi sytuację na Górnym Śląsku. Mianowicie 21 XI 1920 r. wrocławski kard. Adolf Bertram wydał dekret zabraniający duchownym pod karą suspensy udziału w plebiscycie na Górnym Śląsku bez zgody miejscowych proboszczów, w większości Niemców. Ponadto zakazywał on wszelkiej działalności duchowieństwu spoza diecezji wrocławskiej. Wspomniany dekret wymierzony był przeciw duchowieństwu polskiemu, a jego forma sugerowała, że został wydany za zgodą Stolicy Apostolskiej. Wywołał on w Polsce powszechne oburzenie o trudnych do przewidzenia konsekwencjach w relacjach państwo-Kościół. Jednocześnie oskarżano nuncjusza ks. Achillesa Rattiego, pełniącego funkcję Wysokiego Komisarza na obszarze plebiscytowym o współudział w opracowaniu dekretu. Wskutek interwencji rządów polskiego i niemieckiego, Stolica Apostolska mianowała nowego Komisarza ks. Giovanniego Battistę Ogno Serra. Udał się on w grudniu 1920 r. na Górny Śląsk z zamiarem ogłoszenia dekretu zabraniającego całemu duchowieństwu na terenach plebiscytowych wszelkiej działalności politycznej. Sekretarz Stanu Stolicy Apostolskiej kard. Pietro Gasparri powiadomił o tym fakcie posła polskiego przy Watykanie Józefa Wierusza-Kowalskiego, który zaaprobował tego rodzaju rozwiązanie. Wspomniani polscy biskupi: Teodorowicz i Sapieha zostali przyjęci 18 lub 19 XII 1920 r. przez papieża Benedykta XV na audiencji, jak również w Sekretariacie Stanu. Przedłożyli wówczas opis negatywnych skutków dla Polski płynących z zamierzonej publikacji dekretu Ogno Serry. Ponadto przedstawili papieżowi deklarację, którą ten zaaprobował, interpretującą dekret Ogno Serry. Podtrzymywano w niej zakaz agitacji plebiscytowej w kościołach, szkołach i budynkach parafialnych, ale zezwalano duchowieństwu na udział w publicznych zebraniach poza świątyniami i budynkami parafialnymi, jak też udzielano prawa głosowania na jedną z wybranych opcji. Tymczasem Ogno Serra opublikował swój dekret 21 XII 1920 r. Do akcji włączył się wówczas poseł J. Wierusz-Kowalski, domagając się zmiany dekretu. W tej sytuacji kard. Gasparri 23 grudnia t.r. polecił Ogno Serra ogłosić dodatek do wspomnianego dekretu; przyznawał w nim prawo głosowania na jedną z wybranych stron, pozwalał duchowieństwu na udział w zebraniach publicznych poza kościołem, szkołą i budynkami parafialnymi, ale za cenę biernego uczestnictwa. Dnia 3 I 1921 r. Ogno Serra opublikował dodatek, z dołączeniem własnego sformułowania ograniczającego udział duchownych we wspomnianych akcjach do roli biernych świadków. Wskutek kolejnej interwencji abp. Teodorowicza i bp. 
opowiem Ci przy sposobności. Nasze poselstwo jest fatalne ${ }^{389}$. Gdyśmy po raz pierwszy przed Gasparim ${ }^{390}$ stanęli z naszymi postulatami, rzekł: ale czegóż wy chcecie, przecie wasz poseł na wszystko się zgodził. W poniedziałek jazda do Paryża. Mówiliśmy z Ojcem Św[iętym] ${ }^{391}$, o Twoim postawieniu sprawy bukowińskiej ${ }^{392}$ i Ojciec Św[ięty] się na to zgodził. Przyjął nas 2 razy na 3 kwadransowej audiencji. Bardzo był łaskaw i mówił za drugim razem: Niechaj Polacy wiedzą i wierzę w to, że kocham Polskę, niech więc nie będą tak porywczy, ale gdy jest jakieś nieporozumienie, niechaj zaczekają cierpliwie do mego rozpatrzenia ufając, że im krzywdy nie zrobię.

Ściskam Cię serdecznie i pozdrawiam z duszy

Józef

\section{Dokument 146}

\section{Mój Drogi!}

Papiery wszystkie dostałem i posyłam je przez ministerium gdzie należy. Zrobione wszystko bardzo pracowicie i doskonale. Była teraz kwestia wysłania mnie i Sapiehy do Rzymu. Wytłumaczyłem, że to niewskazane posyłać zawsze tych samych, bo myślą w Rzymie, że tylko Ci jedni biskupi walczą, ale dobrze jest odmienić. Zaproponowałem

Sapiehy w Rzymie przez posła J. Wierusza-Kowalskiego, kard. Gasparri polecił 10 II 1921 r. Ogno Serra ogłosić kolejne wyjaśnienie do wydanego 3 stycznia dokumentu. Stwierdzał w nim, że bierna asystencja na zebraniach publicznych nie oznacza zakazu wypowiadania duchowieństwu z prawem udziału w plebiscycie swoich opinii, ale sprzeciwia się prowadzeniu przez nie agitacji bądź przewodniczenia zebraniom. S. Wilk, Episkopat Kościoła, s. 341-345.

389 Przy Stolicy Apostolskiej funkcjonował w 1. 1919-1921 poseł polski Józef Wierusz-Kowalski (18661927). Historycy zarzucają mu całkowity brak orientacji w pragmatyce kanonicznej, brak konsekwencji w działaniu, niezręczność i lekkomyślność w ocenie sytuacji oraz dezorientację w dobie plebiscytu na Śląsku. Z. Zieliński, Udziat Adama Stefana Sapiehy w sprawie ślaskiej podczas plebiscytu w roku 1921, w: Księga Sapieżyńska, t. 2, red. J. Wolny, Kraków 1986, s. 94-100.

390 Właściwie: Gasparri Pietro (1852-1934), włoski duchowny, święcenia kapłańskie w 1877 r. w Rzymie, od 1880 r. wykładowca prawa kanonicznego w Instytucie Katolickim w Paryżu, 1898-1901 delegat apostolski w Ekwadorze, Boliwii i Peru, sekretarz Kongregacji Nadzwyczajnych Spraw Kościelnych; był współtwórcą reformy Kurii Rzymskiej za Piusa X oraz autorem w 1917 r. Kodeksu Prawa Kościelnego, 1914-1930 sekretarz Stanu Stolicy Apostolskiej, kardynał. J. Grzywacz, Gasparri Pietro, w: EK, t. 5, red zbior., Lublin 1989, kol. 877.

391 Ówczesny papież to Benedykt XV (1854-1922), rządzący Kościołem w 1. 1914-1922.

392 Dnia 2 XII 1920 r. abp Bilczewski konferował w Warszawie z ministrem spraw zagranicznych Eustachym Sapiehą na temat ewentualnego wyłączenia Bukowiny - położonej po 1918 r. poza granicami Polski spod jurysdykcji arcybiskupa lwowskiego ob. łac. Minister sugerował, aby tę kwestię przedstawić papieżowi przez wyjeżdżających właśnie do Rzymu abp. Teodorowicza i bp. Sapiehę. Oczywiście lwowski metropolita stał na stanowisku utrzymania status quo. Zdaniem ministra rząd nie może jednak w tej kwestii wywierać nacisku na Watykan o zachowanie jurysdykcji metropolity lwowskiego na Bukowinie, kiedy jednocześnie domaga się pozbawienia takowej kard. Bertrama na Górnym Śląsku. Warto w tym miejscu dodać, że dopiero konkordat z 1925 r. pomiędzy Polską a Stolicą Apostolską uregulował tę sprawę na niekorzyść arcybiskupów lwowskich. AALK, bsygn., J. Bilczewski, Dziennik, s. 826.

b Obok na marginesie adnotacja ręką abp. Bilczewskiego: „List otrzymałem 26/I [1]921 za pośredn[ictwem] podsekr[etarza] stanu Dąbrowskiego".

a List pisany jest na pojedynczej, nieliniowanej kartce formatu zbliżonego do A4. Brak znaku wodnego. 
dla sprawy wschodniogalicyjskiej wysłać Ciebie, dla sprawy w ogóle wschodu ${ }^{393}$ Rop$\mathrm{pa}^{394}$. W tej sprawie była deputacja u Witosa i on się na to zgodził. Proszę Cię więc, byś był gotów do podróży i byś materiał potrzebny przygotował. O Roppie nie można nigdzie głośno mówić, bo będzie miał trudności w Rosji.

Jestem jak w ukropie politycznym i dlatego krótko Ci piszę. Przeżywamy konanie gabinetu, może ze wszystkich gabinetów najszkodliwszego ${ }^{395}$.

Serdecznie Cię ściskam

Warszawa, d[nia] 11/VI [1]921

Twój Józef

\section{Dokument 147}

Kochany Księże Arcybiskupie! ${ }^{a}$

Daruj, że Ci tak późno odpisuję, ale musiałem wprzód pomówić z Roppem. Otóż on pisał do Rzymu w tej sprawie przedtem i czeka na wezwanie. Nie wezwany pojechać nie może. W ogóle dzisiaj zdaje mi się nie jest chwila. Z Rzymu usuwają Kowalskiego ${ }^{396}$, jest

${ }^{393}$ We wrześniu 1921 r. rząd polski przedstawił abp. Bilczewskiemu i abp. Edwardowi Roppowi prośbę wyjazdu na koszt państwa do Rzymu z misją omówienia problematyki narodowościowej w Małopolsce Wschodniej i wyjaśnienia genezy walki polsko-ukraińskiej. Lwowski hierarcha wniósł tę sprawę na forum obrad Komitetu Biskupów 27-29 IX 1921 r. w Warszawie. Jakkolwiek zgodzono się co do kwestii niesienia pomocy ze strony episkopatu państwu polskiemu, to jednak wskutek zakwestionowania uprawnień biskupów przez rząd w misji mediacyjnej ze Stolicą Apostolską podjętej zresztą na jego prośbę w dobie plebiscytu śląskiego, episkopat odżegnał się od tego rodzaju działań z obawy przed narażeniem na szkodę tak państwa, jak i własnej powagi. Tę uchwałę zatwierdził zjazd biskupów 21-25 VI 1922 r. z dodaniem, że w sprawach znacznej wagi episkopat z własnej inicjatywy i na własny koszt podejmie odpowiednie kroki u Stolicy Apostolskiej. S. Wilk, Episkopat Kościoła, s. 351.

${ }^{394}$ Ropp Edward (1851-1939), święcenia kapłańskie w 1886 r. w Kownie, 1889-1902 proboszcz w Libawie, 1902-1903 biskup diecezji tyraspolskiej, 1903-1907 biskup diecezji wileńskiej, 1907-1917 zdeponowany przez władze rosyjskie z biskupstwa i deportowany do guberni witebskiej; w $1917 \mathrm{r}$. mianowany ostatnim arcybiskupem mohylowskim oraz administratorem diec. mińskiej. Dnia 19 IV 1919 r. aresztowany przez władze sowieckie i więziony na Łubiance i Butyrkach w Moskwie, został zwolniony jesienią t. r. wskutek interwencji polskiego rządu i Stolicy Apostolskiej; 22 XI 1919 r. przybył do Polski, osiadając w Warszawie. Zorganizował tam w 1921 r. Sekretariat Arcybiskupstwa Mohylowskiego i Sąd Biskupi, a w 1924 r. erygował w Lublinie Instytut Misyjny z myślą kształcenia duchowieństwa do pracy na Wschodzie. Od $1938 \mathrm{r}$. mieszkał w Poznaniu, gdzie zmarł. R. Dzwonkowski, Losy duchowieństwa katolickiego w ZSSR 1917-1939. Martyrologium, Lublin 1998, s. 409-412.

${ }^{395}$ Mowa o rządzie Wincentego Witosa, pełniącego funkcję premiera w okresie 24 VI 1920 - 13 IX 1921.

a Powyżej obcą ręką niebieską kredką błędnie podano nazwisko: „Weber”. Obok tego ołówkiem cyfra: "6". List pisany jest na podwójnej i nieliniowanej kartce formatu zeszytowego. Znak wodny przedstawia tarczę herbową z ukośnymi paskami. Tarczę herbową wieńczy korona. Herb otacza napis: „Rheinisch Bank Post".

${ }^{396}$ Kowalski-Wierusz Józef (1866-1927), studiował w Warszawie, Getyndze, Berlinie, Paryżu i Bernie; był profesorem i rektorem Uniwersytetu Katolickiego we Fryburgu Szwajcarskim, od 1917 r. przebywał w Polsce organizując Katedrę Fizyki na Uniwersytecie Warszawskim, 1919-1921 poseł nadzwyczajny i minister pełnomocny Polski przy Stolicy Apostolskiej, 1921-1924 poseł w Holandii, 1924-1926 poseł w Austrii, 1926-1927 poseł w Turcji. Wierusz-Kowalski Józef, w: Kto byt kim, s. 116. 
w poselstwie interregnum ${ }^{397} \mathrm{i}$ kanikuła. Więc raczej potrzeba zaczekać i mam nadzieję, że się spotkamy wkrótce w Truskawcu.

Najserdeczniej Cię pozdrawiam i proszę o doręczenie do druku listów

Warszawa, d[nia] 11/VII [1]921

Twój Józef

\section{Dokument 148}

Kochany Księże Arcybiskupie! ${ }^{\mathrm{a}}$

Krynica, d[nia] 28/VII [1]921

Bardzo sobie wyrzucam, że Ci dotąd nie napisałem. Ale sytuacja naprawdę jest tak mętna, że trudno nieraz wiedzieć, co lepsze; przy tym liczyłem na to, że z Tobą się w Truskawcu zjadę. Tymczasem list Rektora nie zastał mnie w Warszawie i ja nie wiedząc czy mieszkanie znajdę palnąłem do Krynicy nie wyrzekając się jednak Truskawca. Przyjechałem do Krynicy na tydzień na przerwę sejmową, tymczasem ze sejmu dostałem od moich kolegów urlop i siedzę tu dotąd.

I oto kołowanina. W sprawie wyjazdu Twojego mówiłem z Roppem. Otóż on nie może wyjechać do Rzymu zanim nie dostanie odpowiedzi na swój list, który wysłał przez Rattiego. A znowu Ty wprawdzie nie musisz jechać z nim, ale bądź co bądź nie możesz zanadto się oddalać terminem od czasu jego przyjazdu. Moralnie wasza akcja jest wspólna. Sytuacja nadto jest jeszcze tak niewyjaśniona, że nawet ryzykownym by było puszczać się w podróż przed jej wyjaśnieniem. Zwrot jednak w Rzymie już jest i to dla nas szczęśliwy. Sapieha dostał właśnie list stamtąd bardzo serdeczny. Jest tam i mowa o mnie. Wskazuje to na chęć nawiązania stosunków na nowo. Gdy coś się w tej sprawie ustali, możemy mówić i dyskutować o chwili Twojego wyjazdu. Tymczasem patienza ${ }^{398}$. Czyś czytał list Przeździeckiego ${ }^{399}$ o „Rzeczypospolitej”? Ten człowiek w zamian za obietnicę kardynalatu in aura ${ }^{400}$ sprzedaje się ludowcom i Witosowi. Skulski ${ }^{401}$ jest maklerem, ohydne to, a nad wszystko łamie solidarną jedność episkopatu. Posyłam $\mathrm{Ci}$ w tej sprawie artykuł Zamorskiego ${ }^{402}$, który wiele narobił hałasu.

397 Łac.: bezkrólewie.

a Powyżej obcą ręką niebieską kredką napisano nazwisko: „Teodorowicz”. List pisany jest na dwóch pojedynczych, nieliniowanych kartkach formatu zeszytowego. Brak znaku wodnego.

398 Wł.: spokój.

399 Przeździecki Henryk (1875-1939), warszawski duchowny rzymskokatolicki, wykładowca Seminarium Duchownego w Warszawie, 1918-1939 biskup diecezji podlaskiej, 1919-1926 sekretarz Episkopatu Polski. P. Nitecki, Biskupi, s. 173.

400 Łac.: powietrze, zapach, blask; tu w znaczeniu: w powietrzu.

${ }^{401}$ Skulski Leopold (1877-?), inżynier chemii, właściciel fabryki, prezydent Łodzi, 1916-1919 należał do liderów Ligi Narodowej, w 1919 r. poseł do Sejmu Ustawodawczego; t. r. doprowadził do powstania Narodowego Zjednoczenia Ludowego, 1919-1920 premier Polski, 1920-1921 minister spraw wewnętrznych, w 1923 r. doprowadził do fuzji NZL z PSL „Piast”, ale wnet zrezygnował z aktywności politycznej. W 1. 30. XX stulecia sympatyzował z sanacją, po wrześniu 1939 r. aresztowany przez NKWD i deportowany do Związku Sowieckiego, gdzie zaginął bez wieści. J. Gołębiowski, Skulski Leopold, w: Kto byt kim, s. 66-67.

${ }^{402}$ Zamorski Jan (1874-1948), absolwent romanistyki, nauczyciel w Tarnopolu, założyciel kół TSL, kółek rolniczych i Kas Raiffaisena, 1907-1918 poseł do parlamentu austriackiego, 1913-1914 poseł do Sejmu 
Serdecznie Cię ściskam i jak najlepszych owoców kuracji życzę. Twój

Przyjadę do Truskawca 7 wieczorem albo 8.

Józef

Dokument 149

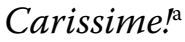

Ucieszyłem się bardzo Twoim listem i odpisuję Ci już do Lwowa. Przede wszystkim, co do jazdy do Warszawy to musisz być na nią gotów. Idzie o to, byśmy się biskupi z komitetu koniecznie teraz zjechali. Już zaczynają pisać po gazetach („Kurier Lwowski”), że się na rozłam u nas zanosi. Teraz zaś byli u mnie księża z różnych dzielnic Polski, by mnie pytać, co ma znaczyć list Ks. Przeździeckiego i dlaczego w episkopacie w takiej ciężkiej chwili nie ma jednolitej orientacji. Sapieha może być w Warszawie 10 września. Może byś wtedy przyjechał? Telegrafowałem już do Dalbora. Co do mnie, to się wybiorę do Warszawy już około 3. Na Ciebie i na Twój przyjazd bardzo liczę. Ty masz wpływ na Kak[owskiego], który kompletnie jest pod wpływem Przeź[dzieckiego]. Dam Ci missalia ${ }^{403}$ tylko powiedz mi ile? Nie wiem czy nie za mała suma, bo po 130 marek.

Ucieszyła mnie Twoja wiadomość o pomyśle Dalbora wysłania listu do mnie i dziękuję Ci serdecznie za poparcie. W tych walkach, które mnie jeszcze w sejmie czekają, dużo to dla mnie znaczy ${ }^{404}$. Ale przede wszystkim dla opinii publicznej zupełnie zdezorientowanej po liście Przeźd[zieckiego] będzie taki list zewnętrznym wyrazem i dowodem jedności episkopatu, a na ten temat niestety właśnie w związku z tą sprawą więcej mówię niżby należało. Wreszcie wobec listu ostatniego papieskiego do biskupów polskich $^{405}$ boję się bardzo o to, że komentarze tendencyjne da jedynie lewica, która już

Galicyjskiego; członek Ligi Narodowej, założyciel „Tygodnika Podolskiego” i „Głosu Polskiego” oraz spadkobierca po ks. S. Stojałowskim „Wieńca-Pszczółki”, 1919-1927 poseł do Sejmu RP. C. Brzoza, Zamorski Jan, w: Kto byt kim, s. 485.

a Powyżej na lewo ręką abp. Bilczewskiego data: „[1]921”, a na prawo: „Arc[ybiskup] Teodorowicz w sprawie skierowanych przeciw niemu ataków". List pisany jest na podwójnej, nieliniowanej kartce formatu zeszytowego. Znak wodny przedstawia w zdobionym otoku napis „Ivory Paper”.

${ }_{403}$ Łac.: intencje i stypendia mszalne.

404 Nawiązanie do kontekstu wydarzeń związanych z misją rzymską abp. Teodorowicza i bp. Sapiehy na rzecz plebiscytu śląskiego. Kiedy pierwszy z nich ujawnił fragment raportu posła Józefa Wierusza-Kowalskiego do polskiego MSZ z niezbyt pochlebną opinią o postępowaniu sekretarza Stanu Stolicy Apostolskiej kard. P. Gasparriego, wybuchł skandal dyplomatyczny. Do szczególnego napięcia doszło na linii poseł polski - sekretarz Stanu. Całe wydarzenie weszło na wokandę Sejmu RP, kiedy posłowie z PSL „Piast” zażądali zbadania misji abp. Teodorowicza w Rzymie, uznanej przez nich za antypaństwową. Ormiański hierarcha podczas plenarnego posiedzenia Sejmu 20 maja złożył wyjaśnienie, po czym w czasie kolejnych posiedzeń komisji spraw zagranicznych przedstawił szczegółowy opis prowadzonych w Rzymie działań. W pierwszych dniach lipca 1921 r. uważano sprawę za wyjaśnioną. Historycy przypuszczają, że przyczyniło się do tego oświadczenie komisarza plebiscytowego na Śląsku Wojciecha Korfantego o udostępnieniu abp. Teodorowiczowi dokumentów plebiscytowych. S. Wilk, Episkopat Kościoła, s. 347-348,

${ }^{405}$ Reminiscencje plebiscytu śląskiego znalazły swe odbicie w liście papieża Benedykta XV do biskupów polskich z 16 VII 1921 r. Autor przypomniał w nim zabiegi Stolicy Apostolskiej na rzecz niepodległości Polski, akcentując wyznawaną zasadę bezstronności, stosowaną także podczas plebiscytu. Odniósł się nadto 
dzisiaj wyskakuje z radości. Otóż z naszej strony powinniśmy tę robotę uprzedzić i pośrednio czy bezpośrednio wykazać, iż wcale aluzji tego listu do nas w oświetleniu lewicy nie przyjmujemy i my raczej, a nie oni, powołani jesteśmy do tłumaczenia znaczenia listu. Bo czy podobna pomyśleć, ażeby Szeptyckiemu dawano aprobaty i pochwały za jego antynarodową i antypaństwową robotę i dla niego były listy pochwalne, a dla nas jakby dla przestępców listy naganne? A taki zaś komentarz chce dać lewica. Sądzę więc, że zsolidaryzowanie się episkopatu koło aktu ściśle kościelnego i ponad [... $]^{\mathrm{b}} \mathrm{w}$ interesie Kościoła jakim był nasz wyjazd do Rzymu będzie i z tego względu ważną i doniosłą manifestacją. Tylko z takim listem niedobrze by było zwlekać aż do konferencji komitetu, na którym inne będą potrzebne ogłoszenia albo konkluzje. Na razie tyle. Za kilka dni obaczę się z Tobą, a mam do omówienia ważne sprawy.

Najserdeczniej Cię ściskam

Truskawiec, 20/VIII [1]921

Twój Józef

\section{Dokument 150}

18/X [1]921

Kochany Księże Arcybiskupie! ${ }^{\mathrm{a}}$

Polecam Ci oddawcę listu ${ }^{\mathrm{b}}$, którego posłał Paderewski tu do Polski, ażeby nawiązać pewne stosunki zwłaszcza w sprawach Kościoła amerykańskiego. Nazwisko pewnie Ci znane. Skirmunt ${ }^{406}$ przesyła Ci przez niego list prawdopodobnie z wezwaniem do Ciebie jazdy do Rzymu. Otóż bądź bardzo ostrożny. Wczoraj Roppowi wręczył nuncjusz telegram od Gasparriego, w którym niedwuznacznie go prosi, aby do Rzymu nie przyjeżdżał pod pozorem, że Ropp tu potrzebny dla składek rosyjskich. Następnie Skrzyński ${ }^{407}$ ma trudności z uregulowaniem w Rzymie wyboru biskupów. Pewno Cię na to wzywają,

do relacji władza państwowa - duchowieństwo. Czynniki państwowe nie powinny przeszkadzać osobom duchownym w spełnianiu ich zadań, unikając jednostronnej ingerencji w życie religijne. $Z$ kolei duchowieństwo jakkolwiek może korzystać z praw obywatelskich, to z racji swego religijnego powołania nie powinno angażować się w sprawy polityczne. S. Wilk, Episkopat Kościoła, s. 350.

b Wyraz nieczytelny.

a List pisany jest na podwójnej, nieliniowanej kartce formatu zeszytowego. Brak znaku wodnego i miejsca wystawienia dokumentu.

b Odnośnie do tego, na marginesie, ręką abp. Bilczewskiego, dopisek: „Dr Orłowskiego z Ameryki”.

406 Skirmunt Kazimierz (1861-1931), polski duchowny rzymskokatolicki diecezji krakowskiej, dr teologii, prawnik, od 1897 r. urzędnik Sekretariatu Stanu Stolicy Apostolskiej, od 1919 r. radca kanoniczny Ambasady Polskiej przy Watykanie, relator spraw polskich na gruncie rzymskim, patriota polski, protonotariusz apostolski, kanonik honorowy Kapituły Metropolitalnej w Wilnie i Bazyliki Najświętszej Marii Panny w Monte Santo. Zmarł 26 V 1931 r. w Rzymie. H. Fokciński, Skirmunt Kazimierz, w: PSB, t. 38, red. zbior., Warszawa-Kraków 1997-1998, s. 177-178.

${ }^{407}$ Skrzyński Władysław (1873-1937), prawnik, przed 1918 r. pracownik administracji i służby dyplomatycznej austro-węgierskiej. Po 1918 r. pracował w polskim MSZ; w 1919 r. był podsekretarzem stanu, 19191921 poseł nadzwyczajny i minister pełnomocny w Madrycie, 1921-1924 poseł, a 1924-1937 ambasador RP w Watykanie. Skrzyński Wtadystaw, w: Kto byt kim, s. 112. 
a to nie nasza rzecz im pomagać w takiej rzeczy. Nie szkodzi więc sobą się podroczyć i dać im też to poczuć, a niepotrzebnie się nie narażać.

Serdecznie Cię ściskam

Będę za kilka dni w[e] Lwowie.

Twój Józef

\section{Dokument 151}

\section{Carissime! ${ }^{\mathrm{a}}$}

Coś mi głowa nie statkuje i boli, więc trochę później Cię odwiedzę. A tymczasem prośba do Ciebie od episkopatu. Jest projekt rządowy uposażenia tymczasowego kleru. Jeszcze niewniesiony formalnie, ale gotowy. Idzie więc o to, byś nacisnął na Michalskiego $^{408}$, by żadnych trudności nie robił. Byłem już u niego z Sapiehą w tej sprawie. Ale poprzyj jeszcze od Siebie. Dobre to zrobi wrażenie na biskupach, bo ci z Królestwa markotni na Ciebie i Pelczara, że w pojedynkę otrzymujecie koncesję. Kakowski się wyraził w tym duchu. Życzenia Ci najserdeczniejsze zasyłam.

Twój

24/XII [1]921

† Teodorowicz

Dokument 152

Carissime! ${ }^{\mathrm{a}}$

Warszawa, d[nia] 29/XII 1921

a Powyżej obcą ręką niebieską kredką napisano nazwisko: „Teodorowicz”, oraz obok ołówkiem liczbę: „24". List pisany jest na pojedynczej, nieliniowanej kartce formatu zeszytowego. W nagłówku nadruk: „Sejm Ustawodawczy Rzeczypospolitej Polskiej". Brak miejsca wystawienia dokumentu.

${ }^{408}$ Michalski Jerzy (1870-1956), dr prawa, 1907-1911 prof. nadzwyczajny skarbowości i prawa skarbowego na UJ, wykładowca prawa państwowego na Studium Rolniczym UJ i Akademii Handlowej w Krakowie, 1911-1924 dyrektor Banku Krajowego Galicji i Lodomerii we Lwowie, 1911-1922 wykładowca na Wydziale Prawa i Umiejętności Politycznych Uniwersytetu Lwowskiego (od 1916 r. prof. zwyczajny nauki skarbowości oraz nauki administracji i austriackiego prawa administracyjnego), 1911-1922 wykładowca ekonomii społecznej w Politechnice Lwowskiej (od 1920 r. prof. honorowy), 1921-1922 minister skarbu, 1922-1924 dyrektor naczelny Polskiego Banku Krajowego, 1922-1927 poseł do Sejmu, 1924-1939 wykładowca ekonomii na Politechnice Warszawskiej, 1945-1950 prof. ekonomii na UJ i Akademii Górniczo-Hutniczej w Krakowie. Michalski Jerzy, w: Kto byt kim, s. 54; Uniwersytet Jana Kazimierza we Lwowie. Skład Uniwersytetu w latach akademickich 1921/1922 i 1922/1923, Lwów 1923, s. 15.

a List pisany jest na pojedynczej, nieliniowanej kartce formatu zeszytowego. W nagłówku nadruk: „Sejm Ustawodawczy Rzeczypospolitej Polskiej”. 
Ależ dopiero musiałbym odszukać niemieckie tłumaczenia. A to nie tak łatwa sprawa. Zacznę jednak. Lutosławski ${ }^{409}$ jest na wsi u matki ${ }^{410}$, ale poślij co chcesz do niego pod adresem: p[ani] Skulimowska ${ }^{411}$, [ul.] Miodowa 16.

Moje panie jak widzę pospieszyły się z ogłoszeniem i nawet fałszywą godzinę podały, ale już przepadło.

Najserdeczniej Cię ściskam

Józef

\section{Dokument 153}

Bądźa tak dobry i podaj nam bliższe dane co do mowy Kiernika ${ }^{412}$ względnie wypowiedzenia Kiernika do księży w Wadowicach ${ }^{413}$. Idzie o to, by robotę ludowców, którzy brużdżą w sprawie pensji dla księży, zdemaskować. Musimy jednak powołać się na kogoś, by nam inaczej nie zaprzeczono, a przynajmniej musimy mieć pewność, że on to mówił.

Serdecznie Cię ściskam.

${ }^{409}$ Lutosławski Kazimierz (1880-1924), po studiach medycznych, fizycznych i teologicznych przyjął święcenia kapłańskie w 1912 r., dr wszechnauk lekarskich i teologii. Początkowo pracował jako katecheta oraz organizował harcerstwo publikując prace popularyzujące idee skautyzmu, 1912-1915 członek Naczelnej Komendy Harcerskiej na Królestwo Polskie, 1915-1918 przebywał w Moskwie organizując polskie szkolnictwo i harcerstwo oraz rozwijał akcję charytatywną. Po powrocie do kraju włączył się w pracę Związku Ludowo-Narodowego; z jego listy był posłem do Sejmu (1919-1924), pracując w komisjach: konstytucyjnej, regulaminowej, oświatowej, spraw zagranicznych. Był jednym z najaktywniejszych mówców sejmowych. Redagował pisma: „Polak-Katolik”, „Wygnaniec”, „Sprawa”, „Bulletin Catholique de Pologne”. Współpracował ze Stowarzyszeniem Młodzieży Akademickiej „Odrodzenie”. Podczas wojny 1920 r. był kapelanem wojskowym. R. Gajewski, Lutosławski Kazimierz, w: SBKSwP, t. 2, s. 95-97.

${ }^{410}$ Majątek rodziny Lutosławskich - Drozdów leżał pod Łomżą.

411 Osoba niezidentyfikowana.

a Tekst pisany jest na wizytówce z nadrukiem: „Arcybiskup Teodorowicz”. Powyżej tego napisu nieczytelne notatki ręką abp. Bilczewskiego. Brak tytulatury, miejsca wystawienia dokumentu i datacji.

${ }^{412}$ Kiernik Władysław (1879-1971), dr prawa, adwokat, od 1903 r. członek PSL, od 1913 r. jeden z przywódców PSL „Piast”, 1919-1933 poseł do Sejmu; w okresie 28 V - 15 XII 1923 r. minister spraw wewnętrznych, 20 XI 1925 - 5 V 1926, 10 - 15 V 1926 r. minister rolnictwa, 1921-1931 członek Rady Naczelnej PSL „Piast”, 1925-1931 członek Zarządu Głównego, 1930-1931 wiceprezes tegoż. Był więźniem w Brześciu, skazany na 2,5 roku więzienia; 1933-1939 jako emigrant mieszkał w Czechosłowacji, 1940-1941 więziony w Krakowie, a potem przebywał pod obserwacją; 1945-1947 minister administracji publicznej, poseł do Krajowej Rady Narodowej, 1947-1952 poseł do Sejmu. Nadal pozostawał w szeregach PSL oraz był członkiem Zjednoczonego Stronnictwa Ludowego, 1956-1966 wiceprezes Towarzystwa „Polonia”. Kiernik Wtadystaw, w: Kto byt kim, s. 152.

${ }^{413}$ Wadowice - miasto powiatowe w woj. Kraków. 


\section{Dokument 154}

\section{Carissime! $^{\text {a }}$}

Sprawą Twojego poleconego zająłem się i znosiłem się z Korfantym ${ }^{414}$. Jutro mam raz jeszcze z nim się porozumieć. Doskonale, że jedziesz ${ }^{415}$. Pisał mi Sapieha z Londynu. Ogólne jest zaniepokojenie polityką Watykanu wobec Rosji, która gorzej zdaje się wygląda niż jest w istocie. Sapieha bardzo liczy na Ciebie. Doskonale, że wziąłeś Tarnawskiego. Tu w Polsce o niczym dziś więcej nie mówią, jak o polityce Rzymu wobec Rosji. Resztę Ci opowiem widząc się z Tobą. Ja jutro wieczór wyjeżdżam, choć jeszcze muszę być na poobiednim posiedzeniu sejmu.

Najserdeczniej Cię pozdrawiam i cieszę się bardzo na Twój wyjazd

Warszawa, d[nia] 15/V [1]922

Teodorowicz

\section{Dokument 155}

\section{Mój Drogi! ${ }^{\mathrm{a}}$}

Bardzo się cieszę wiadomościami o zdrowiu Twym ${ }^{416}$ ze Lwowa, które mi pozwalają przesłać Ci gorące życzenia wsparte na ufności, że Bóg modłów naszych wysłucha.

a List pisany jest na pojedynczej, nieliniowanej kartce formatu zeszytowego. Brak znaku wodnego.

${ }^{414}$ Korfanty Wojciech (1873-1939), studiował nauki ścisłe i prawo, 1903-1911 oraz w 1918 r. był posłem ze Śląska do Reichstagu, redagował pismo „Górnoślązak”, założył i redagował periodyk „Polak”. W 1919 r. wszedł do Sejmu Ustawodawczego, w 1920 r. został mianowany polskim komisarzem plebiscytowym na Śląsku. Doprowadził do wybuchu 2/3 V 1921 r. III Powstania Śląskiego, obejmując jego przywództwo, 19221935 był posłem do Sejmu z ramienia górnośląskiej Chrześcijańskiej Demokracji, 27 X - 19 XII 1923 r. minister bez teki w rządzie W. Witosa. Po przewrocie majowym 1926 r. pozostawał w opozycji do sanacji, stając się obiektem jej ataków. W 1927 r. doszło do secesji kierowanej przez niego śląskiej Chadecji ze struktur ogólnopolskich, a on sam został wykluczony ze stronnictwa. Dnia 26 IX $1930 \mathrm{r}$. aresztowany i osadzony w Brześciu, skąd zwolniono go w połowie grudnia t. r.; wtedy wybrano go prezesem Rady Naczelnej PSChD, a nieco wcześniej senatorem RP. Zagrożony ponownym aresztowaniem opuścił w $1935 \mathrm{r}$. Polskę osiadając w Czechosłowacji (do 1938 r.). W 1937 r. wybrano go prezesem Stronnictwa Pracy, 1938-1939 przebywał w Paryżu, po powrocie do Polski wiosną 1939 r. został aresztowany i uwięziony. H. Przybylski, Korfanty Wojciech, w: SBKSwP, t. 2, s. 36-38; Korfanty Wojciech, w: Kto byt kim, s. 48.

${ }^{415}$ Abp Bilczewski zamierzał udać się do Rzymu w celu zapoznania Watykanu m.in. z relacjami Kościoła łacińskiego z Cerkwią unicką na terenie Małopolski Wschodniej.

a List pisany na 1 stronicy liniowanego papieru formatu zeszytowego. W lewym górnym rogu obcą ręką niebieską kredką napisano: „Teodorowicz”.

416 Pierwsze oznaki choroby abp. Bilczewskiego pojawiły się latem 1922 r., kiedy to stracił przytomność podczas wizytacji kanonicznej parafii. Dnia 17 I 1923 r. rozwijająca się choroba „anaemia pernitiosa” zmusiła go do rezygnacji z czynnego trybu życia; położył się więc do łóżka, z którego już nie powstał. Pomimo ubytku sił nadal zajmował się archidiecezją, sprawami Kościoła powszechnego i Ojczyzny. Kilka tygodni przed śmiercią papież Pius XI przesłał mu telegram z błogosławieństwem i zapewnieniem o modlitwach. Niebawem z polecenia papieża odwiedził go bawiący we Lwowie wizytator apostolski o. Genocchi, który ponownie przekazał metropolicie słowa przyjaźni, pamięci oraz modlitwy od Piusa XI. Dnia 20 III $1923 \mathrm{r}$. o godz. 15,30 abp Bilczewski zmarł. Pogrzeb odbył się 24 marca, mowę żałobną wygłosił abp Józef Teodorowicz. Zgodnie z życzeniem zmarłego, jego ciało złożono w grobie ziemnym na Cmentarzu Janowskim we 
Wiem, że Twoim jedynym życzeniem jest, by się wola Boża w Tobie spełniła. Ale naszą to jest już rzeczą molestować wolę Bożą tak, by Cię nam długo Bóg zachować raczył i dla episkopatu, i dla ojczyzny. To co piszę, jest życzeniem, pragnieniem i prośbą wszystkich, którzy tylko o Twej chorobie mówią. Obaczę się za kilka dni z Tobą, a wtedy pogadamy o różnych rzeczach. Tymczasem zaś przyjm ode mnie zapewnienie najoddańszych dla Ciebie uczuć i serca.

Twój

Warszawa, d[nia] 17/III [1]923

† Teodorowicz

Lwowie wśród najuboższych, natomiast zabalsamowane serce umieszczono w kaplicy bł. Jakuba Strzemię w Bazylice Metropolitalnej ob. łac. W ramach ekspatriacji Polaków z Kresów Wschodnich po II wojnie światowej, wywieziono urnę z sercem do kościoła pw. św. Stanisława biskupa w Lubaczowie, po czym w $2001 \mathrm{r}$. powróciła z powrotem do lwowskiej Bazyliki. Natomiast 19 IV 2011 r. przeniesiono doczesne szczątki abp. Bilczewskiego z Cmentarza Janowskiego również do Bazyliki Metropolitalnej we Lwowie. M. Tarnawski, Arcybiskup, s. 198-209; „Nic dla siebie, wszystko dla Boga i bliźniego”, passim; informacje własne autora. 
A4. Uniwersytet Papieski

Tfand Jana Pawła I 